\title{
Benthic polychaeta of the Middle Atlantic Bight: feeding and distribution
}

Gary Russell Gaston

College of William and Mary - Virginia Institute of Marine Science

Follow this and additional works at: https://scholarworks.wm.edu/etd

Part of the Marine Biology Commons

\section{Recommended Citation}

Gaston, Gary Russell, "Benthic polychaeta of the Middle Atlantic Bight: feeding and distribution" (1983). Dissertations, Theses, and Masters Projects. Paper 1539616660.

https://dx.doi.org/doi:10.25773/v5-6eey-mx76

This Dissertation is brought to you for free and open access by the Theses, Dissertations, \& Master Projects at W\&M ScholarWorks. It has been accepted for inclusion in Dissertations, Theses, and Masters Projects by an authorized administrator of W\&M ScholarWorks. For more information, please contact scholarworks@wm.edu. 


\section{INFORMATION TO USERS}

This reproduction was made from a copy of a document sent to us for microfilming. While the most advanced technology has been used to photograph and reproduce this document, the quality of the reproduction is heavily dependent upon the quality of the material submitted.

The following explanation of techniques is provided to help clarify markings or notations which may appear on this reproduction.

1. The sign or "target" for pages apparently lacking from the document photographed is "Missing Page(s)". If it was possible to obtain the missing page(s) or section, they are spliced into the film along with adjacent pages. This may have necessitated cutting through an image and duplicating adjacent pages to assure complete continuity.

2. When an image on the film is obliterated with a round black mark, it is an indication of either blurred copy because of movement during exposure, duplicate copy, or copyrighted materials that should not have been filmed. For blurred pages, a good image of the page can be found in the adjacent frame. If copyrighted materials were deleted, a target note will appear listing the pages in the adjacent frame.

3. When a map, drawing or chart, etc., is part of the material being photographed, a definite method of "sectioning" the material has been followed. It is customary to begin filming at the upper left hand corner of a large sheet and to continue from left to right in equal sections with small overlaps. If necessary, sectioning is continued again-beginning below the first row and continuing on until complete.

4. For illustrations that cannot be satisfactorily reproduced by xerographic means, photographic prints can be purchased at additional cost and inserted into your xerographic copy. These prints are available upon request from the Dissertations Customer Services Department.

5. Some pages in any document may have indistinct print. In all cases the best available copy has been filmed.

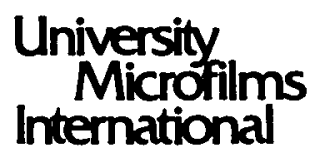

300 N. Zeeb Road

Ann Arbor, MI 48106 
Gaston, Gary Russell

BENTHIC POLYCHAETA OF THE MIDDLE ATLANTIC BIGHT: FEEDING AND DISTRIBUTION

\section{University Microfilms International 300 N. Zeeb Road, Ann Arbor, MI 48106}





\section{PLEASE NOTE:}

In all cases this material has been filmed in the best possible way from the available copy. Problems encountered with this document have been identified here with a check mark

1. Glossy photographs or pages

2. Colored illustrations, paper or print

3. Photographs with dark background

4. Illustrations are poor copy

5. Pages with black marks, not original copy

6. Print shows through as there is text on both sides of page

7. Indistinct, broken or small print on several pages

8. Print exceeds margin requirements

9. Tightly bound copy with print lost in spine

10. Computer printout pages with indistinct print

11. Page(s) author. lacking when material received, and not available from school or

12. Page(s) seem to be missing in numbering only as text follows.

13. Two pages numbered . Text follows.

14. Curling and wrinkled pages

15. Other 


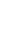




\title{
BENTHIC POLYCHAETA \\ OF THE MIDDLE ATLANTIC BIGHT: \\ FEEDING AND DISTRIBUTION
}

\author{
A Dissertation \\ Presented to \\ The Faculty of the School of Marine Science \\ The College of William and Mary in Virginia
}

\author{
In Partial Fulfillment \\ of the Requirements for the Degree of \\ Doctor of Philosophy
}

by

Gary R. Gaston

1983 
APPROVAL SHEET

This dissertation is submitted in partial fulfillment of the requirements for the degree of

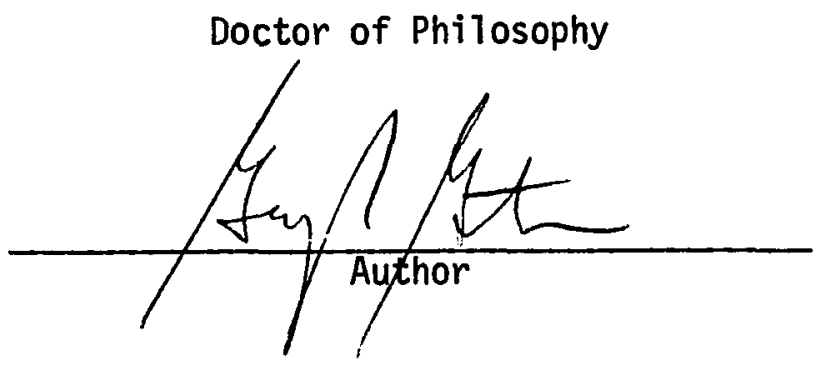

Approved, July 1983
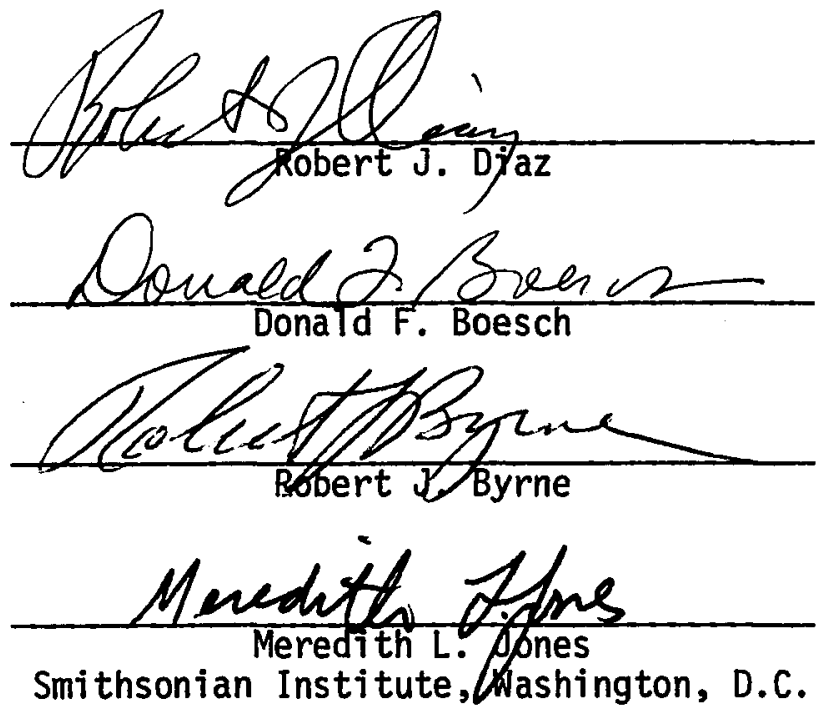

$\frac{\text { Gustagutaue }}{\text { Kristian Fauchard }}$ ii 


\section{TABLE OF CONTENTS}

\section{Page}

ACKNOWLEDGMENTS.................. iv LIST OF TABLES ................. v

LIST OF FIGURES. . . . . . . . . . . . . . . vi ABSTRACT ................... . $x$

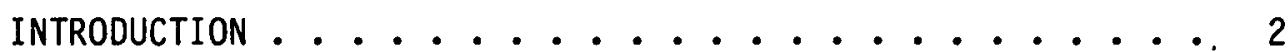
MATERIALS AND METHODS. . ............ 13 RESULTS. . . . . . . . . . . . . . 24

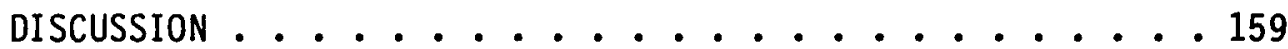
SUMMARY. . . . . . . . . . . . . 168 APPENDIX . . . . . . . . . . . . . . 171 BIBLIOGRAPHY . . . . . . . . . . . . . 175 


\section{ACKNOWLEDGMENTS}

I gratefully acknowledge the five committee members who advised me. I am especially indebted to Dr. Donald Boesch and Dr. Robert Diaz with whom I worked for several years. Additionally, Or. Kristian Fauchald and Dr. Meredith Jones advised me on interpretation of gut contents data, and made available the polychaete specimens necessary for this investigation. Dr. Robert Byrne provided sediment data, literature, and interpretations of the sediment data. A 11 committee members provided constructive reviews of the dissertation.

Numerous people at the Virginia Institute of Marine Science provided support. Dr. Frank Perkins provided guidance and helped interpret SEM prints. Ms. Patrice Mason supervised preparation of SEM material, completed the photographs, and helped interpret the prints. Ms. Ginny Shaw wrote the computer programs for the statistics used in the study.

I am also indebted to many people at McNeese State University. Dr. Larry DeRouen provided encouragement and guidance. Ms. Terri Kirby is gratefully acknowledged for typing the entire paper. Mr. Patrick Cormier provided final drafts of the illustrations.

Funding for this research was supported in part by Bureau of Land Management Contract AA550-CT6-62 with the Virginia Institute of Marine Science. 
LIST OF TABLES

Table

Page

1. General sediment characteristics at each station . . . . 14

2. Sampling schedule and replication of grab samples. . . . . 17

3. Feeding biology classes, distribution, and relative abundance of all species collected. . . . . . . 25

4. Site groups selected from numerical classification of polychaetes collected at stations across the shelf

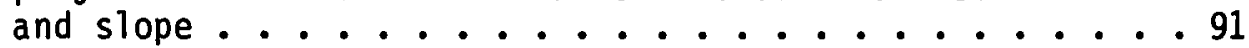

5. Mean values of sediment parameters and depth of Area $B$ stratified random habitats.............. . . . . . . . . .

6. Station groups by habitat selected from numerical classification of polychaetes collected in Area B. . . . . . 136

7. Percentage of each feeding, motility and morphological classification by habitat in Area B.......... . . . . . . .

8. Mean values of sediment parameters and depth of Area $E$ stratified random habitats.............. . . . . . . . . . .

9. Station groups by habitat selected from numerical classification of polychaetes collected in Area E. . . . . . 150

10. Percentage of each feeding, motility and morphological classification by habitat in Area E . . . . . . . 151 


\section{LIST OF FIGURES}

Figure

Page

1. Bathymetry of the New York Bight (Uchupi 1970) . . . . . 8

2. Topographic features of the Middle Atlantic Bight (Swift et

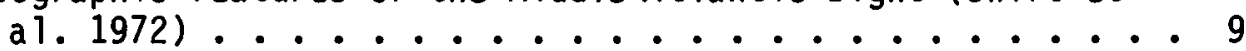

3. Sampling sites occupied for macrobenthic sampling during the BLM Middle Atlantic Benchmark Program. General topography and approximate depth are provided.......... 11

4. Scanning electron micrograph of gut contents of Eunice vittata. Diatom is at center and coccolith is at upper right ....................4 4

5. Scanning electron micrograph of fecal pellet of Eunice vittata. Centric diatoms are at lower right and near

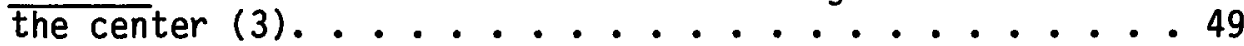

6. Scanning electron micrograph of centric diatom (Coscinodiscus sp.) in gut of Eunice vittata ............ 50

7. Scanning electron micrograph of gut contents of Eunice vittata. Plant material extends from lower left to upper right .................... 51

8. Scanning electron micrograph of gut contents of Eunice vittata. Centric diatoms are at lower right and upper left. Two coccoliths are at left center. .......52

9. Scanning electron micrograph of gut contents of Marphysa bellii. Diatom fragments are at bottom and upper

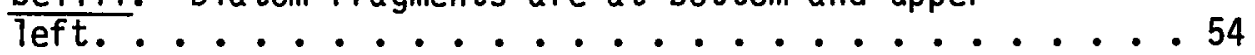

10. Scanning electron micrograph of gut contents of Marphysa bellii. Polychaete seta is at upper left. Feldspar particles are at lower right and upper center ......55

11. Scanning electron micrograph of gut contents of Marphysa bellii. Polychaete seta is at upper left. Two coccoliths are at lower right .......... . . 56

12. Scanning electron micrograph of bacteria among the gut contents of Onuphis pallidula ........... . 77 
Figure

Page

13. Scanning electron micrograph of gut contents of Onuphis pallidula. Diatom at center is Nitzchia sp.. .... 78

14. Numerical classification of Middle Atlantic Bight stations. Classification hierarchies are indicated at left. Sampling sites of each site group are in Table 4 (Bray-Curtis similarity, flexible sorting, beta $=-0.25) \ldots . . .90$

15. Percentage of polychaete feeding, motility and morphology by major habitat. Carnivores and herbivores are excluded. [subsurface deposit feeders (B); surface deposit feeders $(S)$; suspension feeders (F); discretely motile (D); motile $(M)$; sessile (L); jawed (J); soft proboscis $(X)$; tentaculate $(T)$; pumping $(P)] \ldots . \ldots 94$

16. Ternary diagram of broad scale sampling sites identified by habitat. Sites are distributed by percentage of the three components of deposit feeding polychaetes: surface, subsurface and suspension. Mean values of sites in each habitat are plotted as centroids in small diagram at right . . 97

17. Ternary diagram of broad scale sampling sites identified by habitat. Sites are distributed by percentage of the three components of polychaete motility: motile, discretely motile and sessile. Mean values of sites in each habitat are plotted as centroids in small diagram at right. . . . 998

18. Ternary diagram of broad scale sampling sites identified by habitat. Sites are distributed by percentage of the three primary components of polychaete morphology: jawed, tentaculate and soft proboscis ............ 99

19. Abundance $\left(\mathrm{m}^{-2}\right)$ of surface deposit feeding polychaetes at sampling sites in the Middle Atlantic Bight . . . . . . 103

20. Abundance $\left(\mathrm{m}^{-2}\right)$ of carnivorous polychaetes at sampling sites in the Middle Atlantic Bight. ...........104

21. Abundance $\left(\mathrm{m}^{-2}\right)$ of jawed polychaetes at sampling sites in the Middle Atlantic Bight . . . . . . . . . 105

22. Abundance $\left(\mathrm{m}^{-2}\right)$ of subsurface deposit feeding polychaetes at sampling sites in the Middle Atlantic Bight. . . . . 106

23. Abundance $\left(\mathrm{m}^{-2}\right)$ of suspension feeding polychaetes at sampling sites in the Middle Atlantic Bight . . . . . 107 
Figure

Page

24. Abundance $\left(\mathrm{m}^{-2}\right)$ of motile polychaetes at sampling sites

in the Middle Atlantic Bight. . . . . . . . . . 108

25. Abundance $\left(\mathrm{m}^{-2}\right)$ of sessile polychaetes at sampling sites

in the Middle Atlantic Bight. . . . . . . . . . 109

26. Abundance $\left(\mathrm{m}^{-2}\right)$ of soft proboscis polychaetes at sampling

sites in the Middle Atlantic Bight. ................ 110

27. Abundance $\left(\mathrm{m}^{-2}\right)$ of tentaculate polychaetes at sampling sites in the Middle Atlantic Bight. . . . . . . . .111

28. Abundance $\left(\mathrm{m}^{-2}\right)$ of discretely motile polychaetes at sampling sites in the Middle Atlantic Bight. ......... . . 112

29. Total annelids $\left(\mathrm{m}^{-2}\right)$ at sampling sites in the Middle Atlantic Bight. . . . . . . . . . . . . 115

30. Wet weight mean biomass $\left(\mathrm{g} \mathrm{m}^{-2}\right)$ of annelids at sampling sites in the Middle Atlantic Bight. . . . . . . . 125

31. Evolution of ridge and swale topography (Stubblefield and

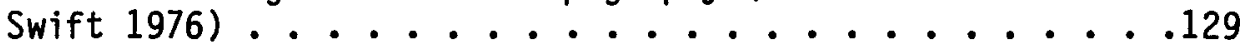

32. Distribution of major habitats in Area B. Quarterly and stratified random sampling sites are identified by points (redrawn from Boesch 1979) ..................

33. Numerical classification of Area B stations (Bray-Curtis similarity, flexible sorting, beta $=-0.25) . . . . . .135$

34. Ternary diagram of Area B sampling sites identified by habitat. Sites are distributed by percentage of the three components of deposit feeding polychaetes: surface, subsurface and suspension. Mean values of sites in each habitat are plotted as centroids in small diagram at

right ........................ 140

35. Ternary diagram of Area B sampling sites identified by habitat. Sites are distributed by percentage of the three components of polychaete motility: motile, discretely motile and sessile. Mean values of sites in each habitat are plotted as centroids in small diagram at right. . . . 141 
Figure

36. Ternary diagram of Area B sampling sites identified by habitat. Sites are distributed by percentage of the three primary components of polychaete morphology: jawed, tentaculate and soft proboscis. Mean values of sites in each habitat are plotted as centroids in small diagram at right.142

37. Distribution of major habitats in Area E. Quarterly and stratified random sampling sites are identified by points (redrawn from Boesch 1979a) ....................

38. Numerical classification of Area $E$ stations (Bray-Curtis similarity, flexible sorting, beta $=-0.25) \ldots . . . . .149$

39. Ternary diagram of Area $E$ sampling sites identified by habitat. Sites are distributed by percentage of the three components of deposit feeding polychaetes: surface, subsurface and suspension. Mean values of sites in each habitat are plotted as centroids in small diagram at right.153

40. Ternary diagram of Area $E$ sampling sites identified by habitat. Sites are distributed by percentage of the three components of polychaete motility: motile, discretely motile and sessile. Mean values of sites in each habitat are plotted as centroids in sma 11 diagram at right. . .154

41. Ternary diagram of Area $E$ sampling sites identified by habitat. Sites are distributed by percentage of the three primary components of polychaete morphology: jawed, tentaculate and soft proboscis. Mean values of sites in each habitat are plotted as centroids in small diagram at right.155 


\section{ABSTRACT}

Patterns in the distribution of feeding-biology categories of polychaetous annelids were used to characterize benthic habitats of the Middle Atlantic Bight. Feeding biology classifications were based on recent publications regarding polychaete feeding and on gut-contents analyses of polychaetes collected in the study area. Proportion of carnivorous polychaetes was greatest in coarser sediments, and decreased significantly with depth across the continental shelf. Surface deposit feeders numerically dominated most habitats. Abundance of surface deposit feeders decreased across the continental shelf and sharply increased at the shelf break, paralleling the pattern of water-column production. Proportion of subsurface deposit feeders was greatest in fine-sediment habitats, and increased significantly with depth and percent organic carbon across the continental shelf. Sessile polychaetes generally inhabited physically stable habitats of the study area. Proportion of sessile polychaetes was positively correlated with percent silt and clay and percent organic carbon. Feeding-morphology categories were generally less closely related to habitat differences than were feeding or motility categories. These results suggest that the diverse assemblages of polychaetes that inhabit topographic depressions of the Middle Atlantic Bight ma be dependent on stability of sediment parameters. Furthermore, distribution and abundance of surface deposit feeders may depend on food resources from water-column production, and distribution of sessile polychaetes may be limited by physical disturbance. 
BENTHIC POLYCHAETA OF THE MIDOLE ATLANTIC BIGHT:

FEEDING AND DISTRIBUTION 


\section{INTRODUCTION}

It has been known for many years that there is a relationship between changes in benthic habitats and changes in benthic communities. As sediments grade between habitats, shifts often occur in the relative abundance and composition of the benthic taxa which inhabit them. Recently, interest has centered around shifts in dominance of feeding groups between habitats (e.g. Rhoads 1974, Jumars and Fauchald 1977, Woodin 1978, Fauchald and Jumars 1979, Whitlatch 1981, Maurer and Leathem 1981). These studies provide insight into energy flow through the community and a better understanding of the contribution of benthic communities to the ecosystem.

Maurer and Leathem (1981) investigated distribution of polychaete feeding guilds from Georges Bank, off New England. They applied the polychaete feeding biology categories established by Jumars and Fauchald (1977) to a data set, and examined relationships between combined feeding biology classes ("guilds") and environmental variables. They found significant relationships between certain guilds and depth, fine-grained sediment, and sediment nutrition.

One of the shortcomings of use of the Jumars and Fauchald (1977) classification scheme has been the general lack of data on polychaete feeding. Fauchald and Jumars (1979) reviewed the literature on polychaete feeding. They concluded that many of those data were based on casual observations and speculation, and that before benthic communities could truly be understood more extensive data on feeding were 
needed. They hypothesized feeding modes for all polychaete families, but cautioned that a number of families lacked supportive data.

The purpose of the present investigation was to examine the relationship between Middle Atlantic Bight polychaete feeding biology and environmental variables. The relationship was examined by assigning each polychaete species a feeding biology classification, and then comparing the proportions of each class with physical and biological parameters of the area. The categories used were those of Jumars and Fauchald (1977). Included were three parameters of feeding biology: polychaete feeding; feeding motility; and feeding morphology. Before the polychaetes were classified all species which lacked conclusive data on feeding were dissected for gut content analyses. Included were some of the most species-rich and abundant families of polychaetes (e.g. Onuphidae, Nereidae, Goniadidae, Lumbrineridae). Many of these analyses led to changes in classifications from those hypothesized by Fauchald and Jumars (1979), and used by Maurer and Leathem (1981).

In this study it was expected that changes would occur in the proportional contribution of each polychaete feeding component with changes in available food resources. The first hypothesis was that the proportion of the three polychaete detritivore components (suspension feeders, surface deposit feeders, and subsurface deposit feeders) varied between habitats. To test this hypothesis the relative proportion of each component was compared between habitats of the continental shelf and slope described in terms of environmental parameters (e.g. sediment grain size, organic carbon). 
A second hypothesis posed that the distribution of sessile polychaetes was related to water depth and covariates of depth (e.g. sediment grain size). Jumars and Fauchald (1977) have shown a positive correlation between water depth and proportion of sessile polychaetes off Southern California. They postulated that the correlation was actually due to increased sediment stability with depth. To test this, data collected in outer-shelf ridge fields of the Middle Atlantic Bight were included in the present investigation. Thus, proportion of sessile polychaetes was compared among habitats of comparable depth, but variable sediment stability. It was expected that sessile polychaetes would be associated with finer-sediment habitats.

A third hypothesis concerned the relationship of carnivorous polychaetes to sediment characteristics. Boesch (1979a) reported a trend toward dominance of carnivorous species in coarser sediments of the Middle Atlantic Bight. The a priori hypothesis of this study, therefore, was that proportion of carnivorous polychaetes was related to proportion of coarse sediments. To test this hypothesis, distribution of carnivorous polychaetes was compared with sediment grain size and other sediment parameters.

The proportions of several polychaete morphology classes were examined by habitat. It was expected that soft proboscis polychaetes would be in greatest abundance in finer sediments and areas of high organic carbon, since the majority were expected to deposit feed. Jawed polychaetes were expected to dominate coarse sediment habitats as Maurer and Leathem (1981) demonstrated. The hypothesis tested, there- 
fore, was that proportions of the polychaete morphological components were associated with sediment parameters.

\section{Background: Biological Environment}

Collections of Middle Atlantic Bight macrobenthos have continued for many years, although few of the resulting data were published in the formal literature. Sampling throughout the area was conducted during the Woods Hole Oceanographic Institution -- U.S. Geological Survey Continental Margins Program (Emery and Schlee 1963, Wigley et a 1. 1976, Wigley and Theroux 1981). These collections led to the first extensive survey of abundance and biomass of macrobenthos in the study area (Wigley and Theroux 1976). Studies by Pratt (1973) included a classification scheme of 3 depth-related faunal zones. These zones were based on presumed sedimentary regimes in the Middle Atlantic Bight. Recent investigations of the Middle Atlantic Bight conducted by the Virginia Institute of Marine Science under contract with the Bureau of Land Management (Boesch et a1. 1977, Boesch 1979a) were the most extensive biological and chemical studies to date of the area, and provided the data base for this investigation. The BLM data showed complex patterns related to depth-induced changes and habitat complexity.

The importance of interaction between surface deposit feeders, tube dwellers, and burrowers has been well established (Rhoads and Young 1970, Woodin 1974, 1976, 1978, Rhoads 1974, Brenchley 1979, Tsuchiya and Kurihara 1980). Only recently have investigators begun to 
interrelate distribution of benthic species with medium and small scale geological features. Biernbaum (1979) investigated the influence of sedimentary factors on medium scale distribution of Amphipoda. Eckman (1979) investigated small scale distribution patterns associated with sedimentary patterns in Puget Sound. Yingst and Rhoads (1980) and Aller (1978, 1980) studied small scale interactions of species relative to tube dwelling and burrowing, and the enhancement of bacterial growth and concentration of microbes that resulted from such interactions (Yingst and Aller 1982).

\section{Background: Physical Environment}

The geological and physical oceanography of the Middle Atlantic Bight continental shelf has been extensively investigated in recent years (e.g. Emery and Uchupi 1972, Milliman 1973, Swift 1976, Freeland and Swift 1978, Butman and Noble 1979, Butman et a 1. 1979, Welch and Ruzecki 1979, Fischer 1980). The Middle Atlantic Bight is approximateiy $100 \mathrm{~km}$ long, and encompasses a shelf about 100-150 km wide. Until the last decade most of what was known of circulation in the area was inferred from drift bottle and seabed drifter studies. Today these data are supplemented by continuous monitoring data from data buoys, daily satellite imagery, and over flights that help establish monthly surface temperature contour maps. The circulation may be generally characterized as having a mean flow of $5-10 \mathrm{~cm} \mathrm{~s} \mathrm{~s}^{-1}$ to the southwest, paralleling the shoreline (Beardsley et al. 1976). Deep ocean currents periodically provide additional forcing near the shelf break 
(Schmitz 1974), and estuarine waters lead to a density-driven crossshelf flow (Gordon et a. 1976).

The geological processes of the Middle Atlantic Bight have received intense attention over the past decade. The Middle Atlantic shelf is a broad platform (120-160 km wide) extending from Cape Cod to Cape Hatteras. The zone of shelf break is incised by numerous submarine canyons (Figure 1). The sediments of the Middle Atlantic Bight are generally sands or gravelly sands which accumulated during Holocene transgression, and today compose a surficial sheet of sand 0-30 $\mathrm{m}$ thick (Swift et a 1. 1972). These relict sands rest on a nearly flat surface of early Holocent or Pleistocene lagoonal and nearshore deposits (Freeland and Swift 1975, 1978, Stubblefield et a1. 1975, Knebel and Spiker 1977). The relict sands of the Middle Atlantic Bight have been variously modified (Figure 2) into terraces and scarps which are remnants of sea-level still stands (Freeland and Swift 1978), shoal retreat massifs resulting from withdrawal of nearshore or estuarine depositional center (Swift et al. 1972), antecedent stream systems and ridge and swale topography. Though ridge and swa le topography is sma 17 in scale by comparison to canyons or estuarine systems in the Middle Atlantic Bight, these topographic features are widely distributed and locally very important in distribution of macrobenthos (Boesch 1979a). Ridges of these systems are generally spaced about $2 \mathrm{~km}$ apart, are 2 to $10 \mathrm{~m} \mathrm{high}$, and about 9 to $56 \mathrm{~km}$ long (Freeland and Swift 1978).

In general, the Middle Atlantic shelf sediments contain over $90 \%$ sand. This composition is the result of rapid Holocene transgression 
Figure 1. Bathymetry of the New York Bight (Uchupi 1970). 


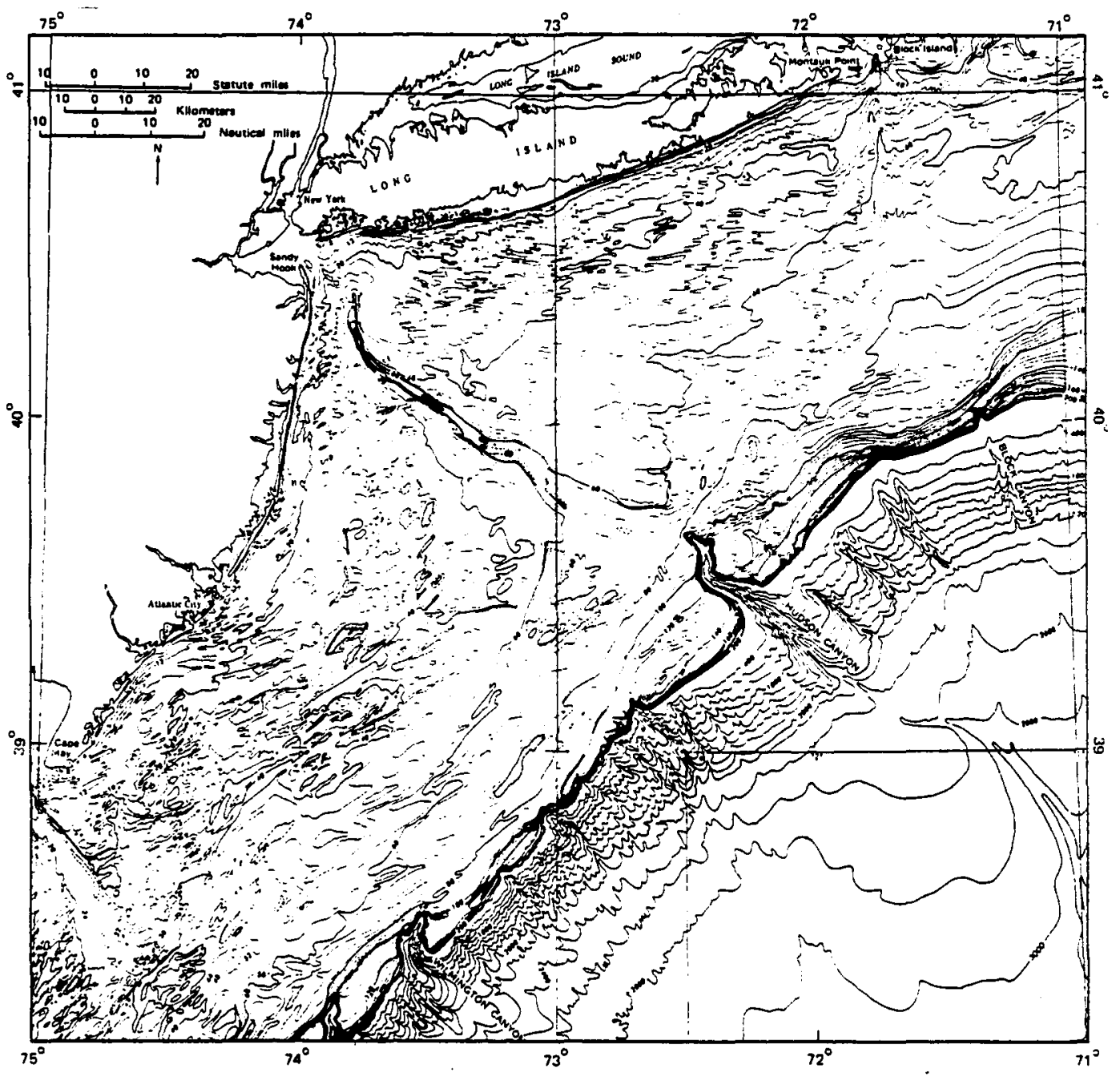


Figure 2. Topographic features of the Middle Atlantic Bight (Swift et a 1. 1972). 


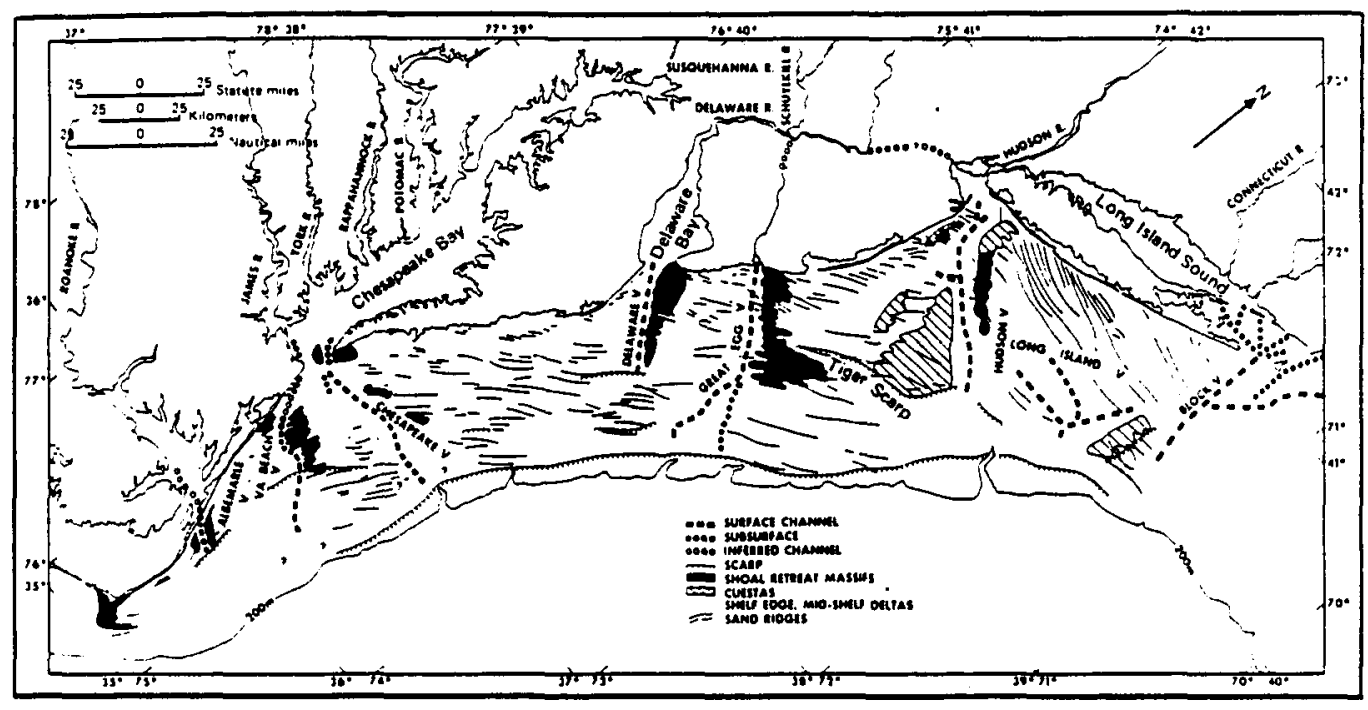


and limited input of modern detrital sediment (Freeland and Swift 1978). The most notable exceptions to this generalization are the fine sediments of the upper Hudson Canyon and topographic depressions associated with the aforementioned features, especially ridge and swa le topography and antecedent stream systems (e.g. Hudson Shelf Valley). Even these are periodically scoured by storm-generated currents.

There is a steep gradient of sediments on the upper continental slope from shelf sands to clayey-silts. The shelf break is generally at about $140 \mathrm{~m}$ depth, but varies from 80 to $160 \mathrm{~m}$ (Freeland and Swift 1978). Off New Jersey the break is at about $120 \mathrm{~m}$ where silt-clay is $5 \%$ to $10 \%$. Sediments at $400 \mathrm{~m}$ (e.g. station H1, Figure 3) contain approximately $30 \%$ silt-clay. At $600 \mathrm{~m}$ silt-clay content exceeds $90 \%$ (Boesch 1979b).

The locations of sampling sites selected for the BLM Middle Atlantic Study and used in this investigation are noteworthy. Stations were generally positioned to sample a range of habitats, with special emphasis on outer shelf petroleum and natural gas lease tract areas. Stations north and south of these areas were positioned to avoid obvious major topographic features, and should not be interpreted as indicative of areas of less topographic complexity.

Little was known of the feeding biology of Middle Atlantic polychaetes prior to the analyses of this investigation. Similarly, knowledge of the surficial geology of the middle and outer shelf s lacking until recent years. The extensive biological and chemical data collected under the auspices of the Bureau of Land Management (1975- 
Figure 3. Sampling sites occupied for macrobenthic sampling during the BLM Middle Atlantic Benchmark Program. Genera 1 topography and approximate depth are provided. 


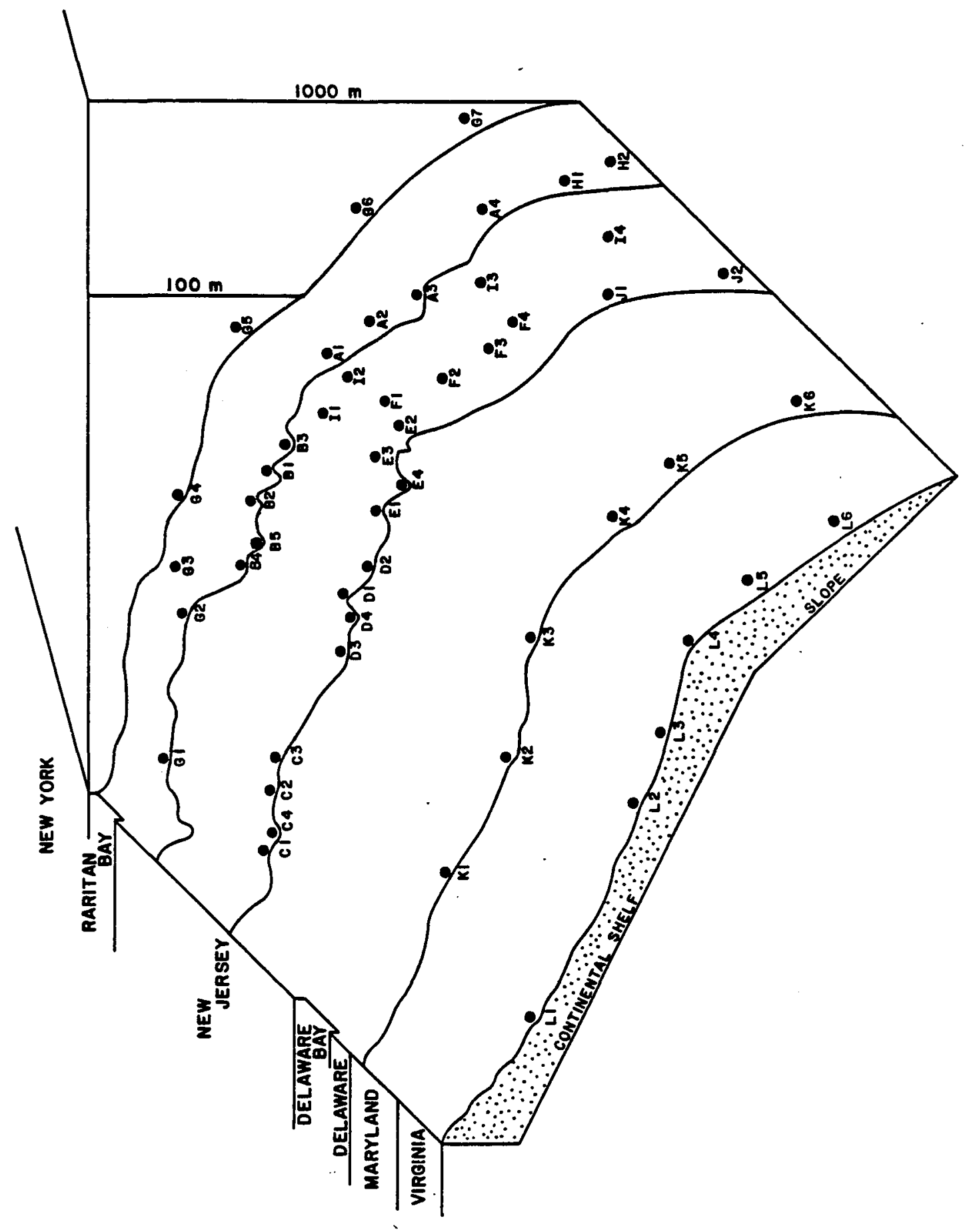


1977) in the Middle Atlantic Bight provided the data necessary to assess patterns in the feeding biology of polychaetes across the Middle Atlantic Bight, and to test the hypotheses posed on distribution of feeding biology parameters. 


\section{MATERIALS AND METHODS}

All species of polychaetous annelids collected in the Middle Atlantic Bight during the BLM program were included in these analyses. Available literature concerning the three feeding biology parameters (polychaete feeding, motility, morphology), summarized for all major polychaete families by Fauchald and Jumars (1979), were used in this investigation except where characterizations from the present study contradict existing characterizations. In cases where contradictions occur, both characterizations are discussed, but the present characterizations are subsequently used. Data concerning species distribution were taken from the data base of the BLM Middle Atlantic Benchmark Program.

During the two year BLM Middle Atlantic Bight study, a total of 52 stations were repetitively sampled (Figure 3 and Table 1). Table 2 lists these stations, and indicates the number of replicates collected and time of collection. All samples of macrobenthos were collected with a $0.1 \mathrm{~m}^{2}$ stainless steel Smith-McIntyre grab sampler equipped with a Benthos Edgerton $35 \mathrm{~mm}$ camera and flash.

Once onboard ship each sample was emptied into a 5-gallon galvanized bucket and washed with sea water. Light-bodied organisms were thus floated out of the sample and collected on a $0.5 \mathrm{~mm}$ mesh Nitex screen below the bucket. The screen was removed when rinsing was completed, placed in a labelled cloth bag, anesthetized in isotonic $\mathrm{MgCl}_{2}$, and killed and fixed with $10 \%$ buffered formalin with Rose 


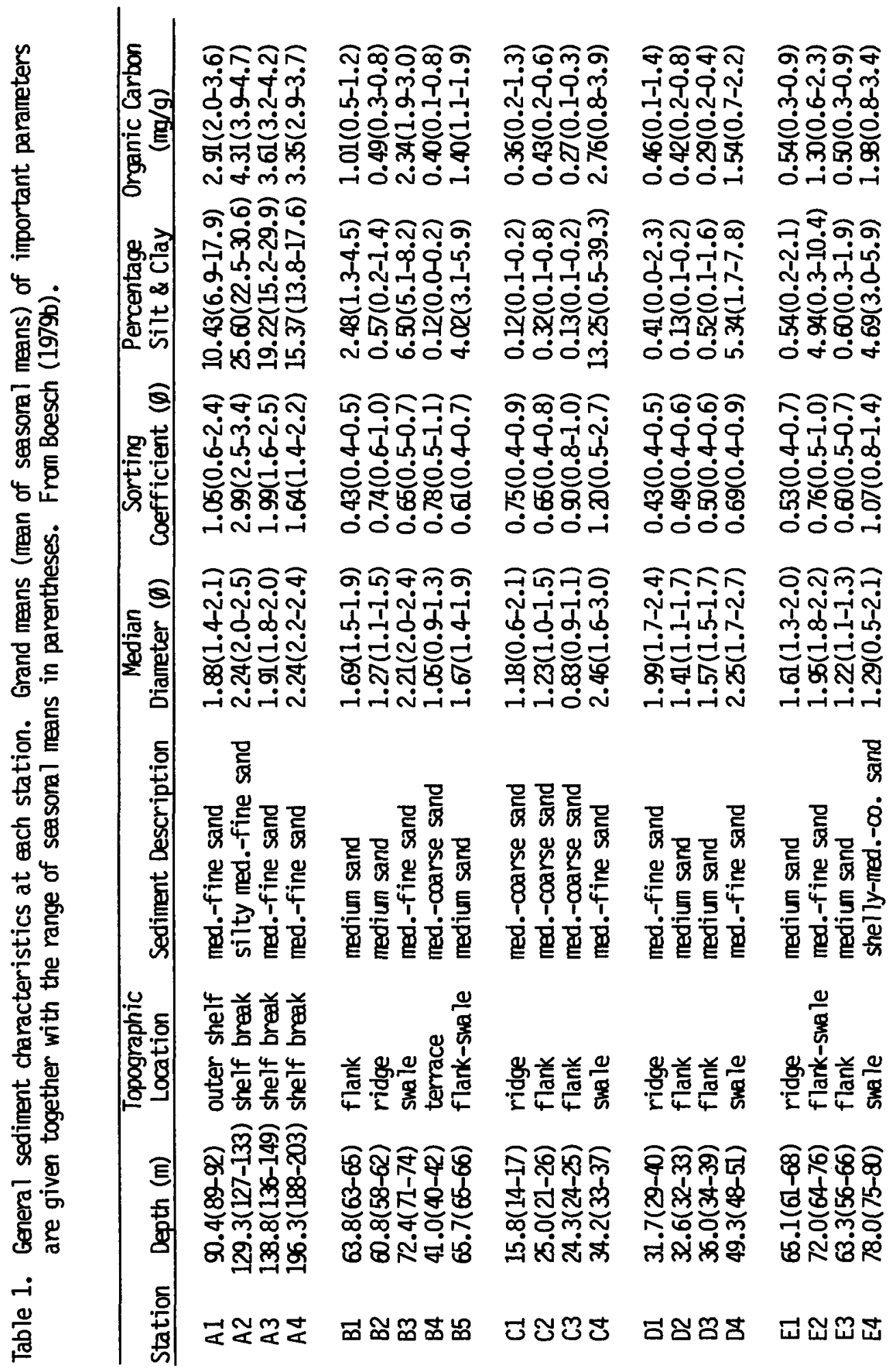




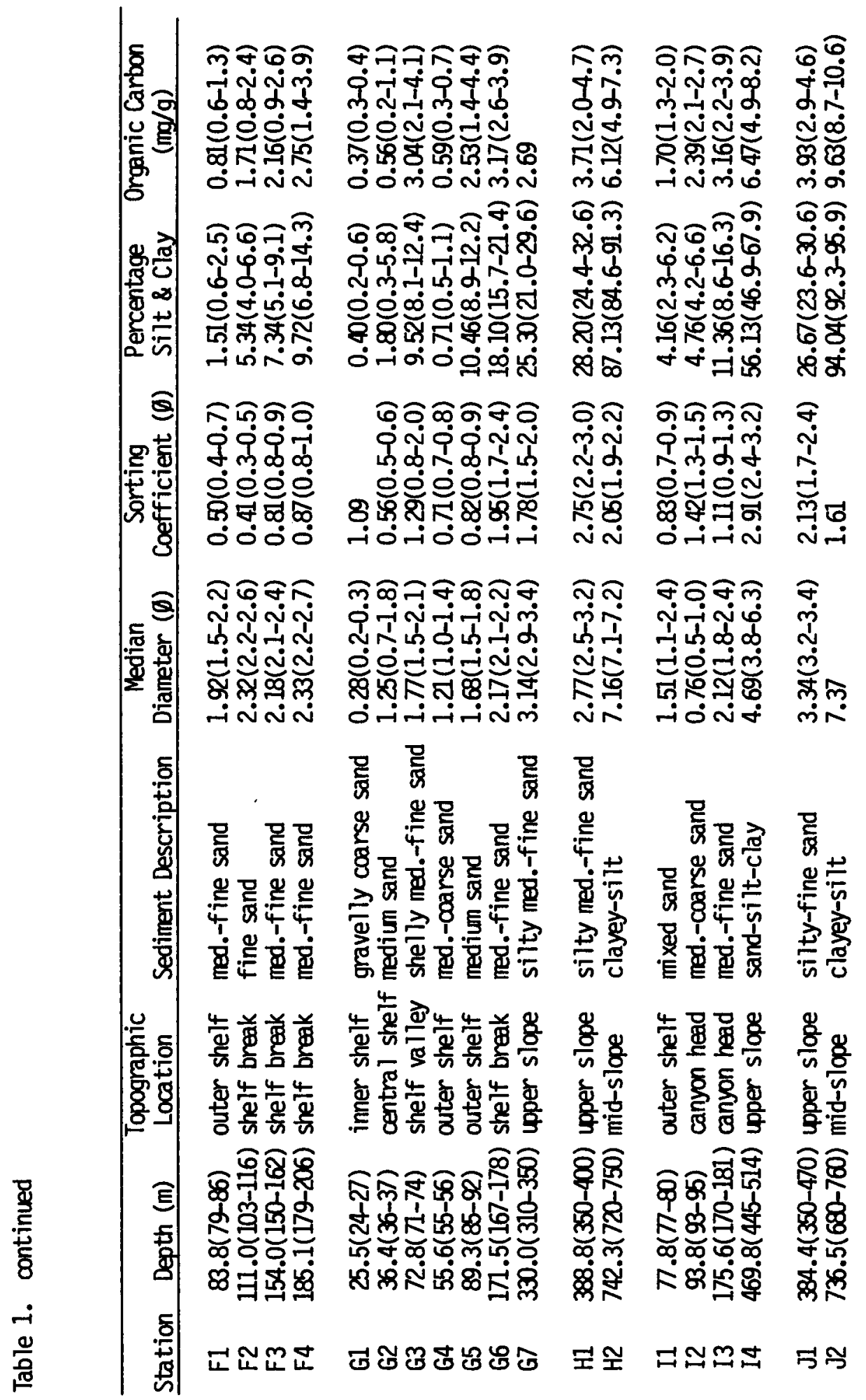




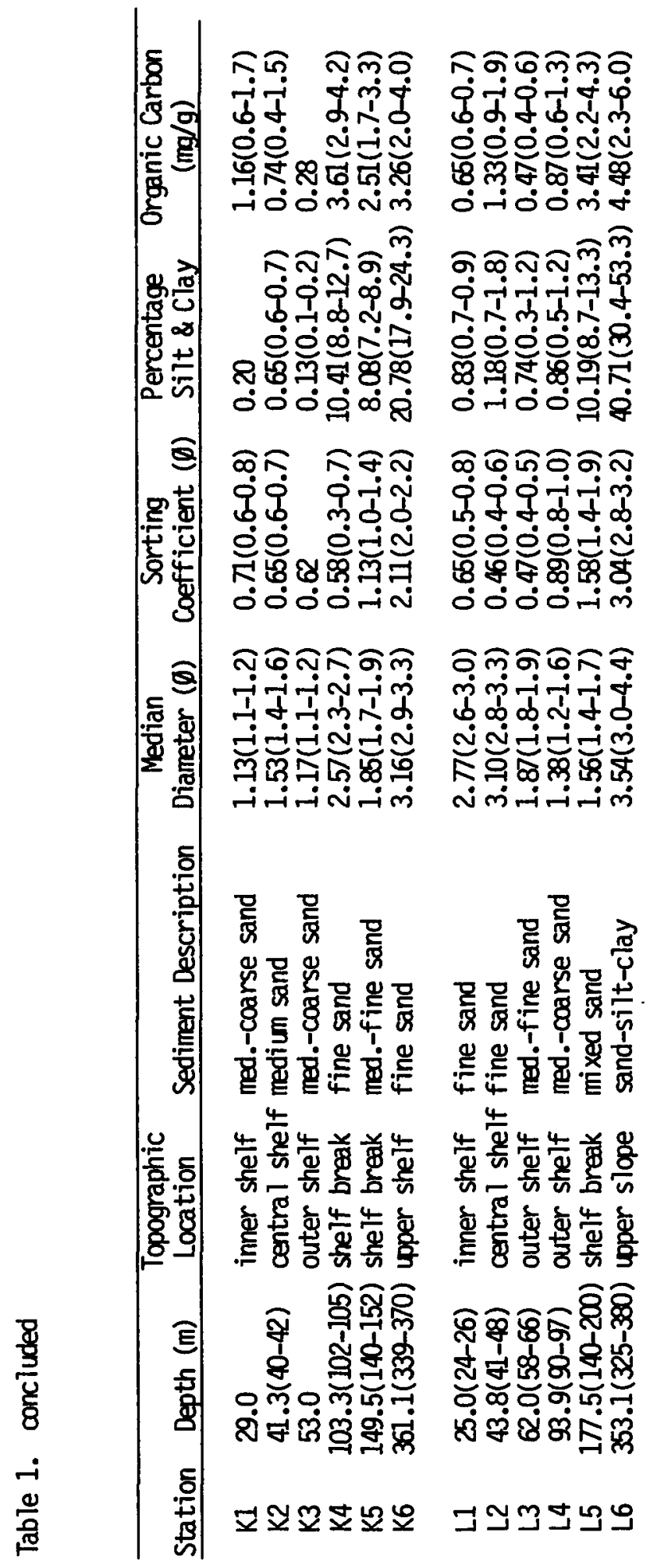


Table 2. Sampling schedule and replication of grab samples taken for macrobenthos.

\begin{tabular}{|c|c|c|c|c|c|c|c|c|}
\hline & & & & Number & of $\mathrm{Re}$ & licates & & \\
\hline & & & $\operatorname{ar} 1$ & & & & YEAR 2 & \\
\hline & 1975 & & 19 & & & & 1977 & \\
\hline Station & $\overline{\mathrm{FaTT}}$ & Winter & Spring & Summer & $\mathrm{FaT1}$ & Winter & Spring & Summer \\
\hline $\begin{array}{l}\text { A 1-4, B1-4, } \\
\text { C2, C4, D1, D4 } \\
\text { E1-4, F1-4 }\end{array}$ & 6 & 6 & 6 & 6 & 6 & 6 & 6 & 6 \\
\hline $\mathrm{Cl}, \mathrm{C} 3, \mathrm{D} 2, \mathrm{D} 3$ & 6 & 6 & 6 & 6 & & & & \\
\hline $\begin{array}{c}\text { B5 (Recolon. } \\
\text { Study) }\end{array}$ & & & & & 6 & 6 & 6 & 6 \\
\hline $\begin{array}{l}\text { G2-6, I I-3, } \\
\text { K2, K4-6 } \\
L 2, L 4-6\end{array}$ & & 6 & & 6 & & 4 & & 4 \\
\hline $\mathrm{H} 1-2, \mathrm{I} 4, \mathrm{J1-2}$ & & 6 & & 6 & & 6 & . & 6 \\
\hline $\mathrm{G} 1, \mathrm{~K} 1, \mathrm{~K} 3, \mathrm{~L} 1$, & L3 & 6 & & 6 & & & & \\
\hline G7 & & 1 & & 6 & & & & \\
\hline
\end{tabular}


Benga 1 as a stain. The sediments and heavy organisms which remained in the bucket (heavy fractions) were washed on a $0.5 \mathrm{~mm}$ mesh screen sieve, treated as above, and returned to the laboratory with the light fraction. Macrobenthic organisms were removed from the sediment in the laboratory, where all specimens were sorted to major taxa, preserved in ethanol, identified to the lowest practicable level, usually to the species level, and counted.

A special habitat delineation study was conducted during the fall 1976 sampling period. The study was designed to delineate mesoscale patterns of distribution of benthic organisms and demersal fishes in areas $B$ and $E$, two areas of complex topography. The term "mesoscale" was defined for the habitat delineation study by Boesch (1979a) as encompassing horizontal distances of $10^{2}$ to $10^{3} \mathrm{~m}$, a scale which includes major topographic features of the shelf, but not the small transient features such as sand ripples, current lineations, and sand waves. The areas were first stratified, based on existing data. Area $B$ was divided into six habitat strata, and Area $E$ into five (e.g. terraces, ridges, ridge flanks, swales). Single grab samples were then randomly collected within each stratum. Samples were processed by the same methods described above; no attempt was made to replicate the samples.

Polychaete specimens to be dissected for gut-content analyses in this study were stored in $70 \%$ ethanol until dissections began. Length and width for all specimens were measured. The widest portion of the anterior body, usually around setiger 5, was measured. Measurements 
were made to the nearest 0.1 millimeter with an ocular micrometer, and where necessary, a hand-held $5.0 \mathrm{~mm}$ scale micrometer and $150 \mathrm{~mm}$ plastic ruler. All specimens were dissected using a stereomicroscope. Exact methods varied somewhat among species, but all specimens of a given species were handled in the same manner. The large specimens (e.g. Nephtyidae, Phyllodocidae, Glyceridae) were first opened with iris scissors to expose the digestive tract. The entire tract was then removed and placed in a dissecting dish with $70 \%$ ethanol. The entire length of the gut was opened with a $0.5 \mathrm{~mm}$ or $1.0 \mathrm{~mm}$ microknife to expose any ingested material. A record was made of the location of any ingested material in the gut (i.e. pharynx, esophagus, intestine). The material was finally mounted in glycerin and viewed with a compound microscope.

Medium-sized specimens $(5.0$ to $50 \mathrm{~mm})$ were generally dissected in glycerin on a depression slide. Most specimens were opened with microscissors or a microknife and the gut material transferred to glycerin on a second slide. Again, a record was made of where the ingested material was located. In some of the elongate species (e.g. Eunicidae, Onuphidae) the ingested material was located by backlighting specimens over a darkfield stereomicroscope stage, and the setigers of the worm containing the ingested material removed, mounted in glycerin, and the material teased from the gut with a probe. The material was then viewed with a compound microscope. Small species (less than $5.0 \mathrm{~mm}$ ) were too samll to dissect with a microknife. These species (e.g. Syllidae, Sphaerodoridae) were mounted whole on a slide in glycerin, 
examined with a steromicroscope, the intestinal wall pierced with a probe where ingested material was located, and the ingested material squeezed out into the glycerin with a probe.

All material viewed with a compound microscope was classified according to origin. Permanent slides were made of most species. The gut content classification included enumerating and measuring the ingested materials and putting them in one of the following classes: 1) prey or prey parts (e.g. setae, spines); 2) live diatoms; 3) dead diatoms or pieces or frustules; 4) foraminifera; 5) dinoflagellates; 6) coarse quartz or feldspar sand; 7) fine sand; 8) sand masses agglutinated with mucus; 9) detritus (percentage of gut filled); 10) fecal pellets; and 11) other (e.g. calcareous sand, plant material).

Examination of gut material under the compound microscope led to inconclusive results for certain species: Marphysa bellii; Eunice vittata; Onuphis pallidula; Ceratocephale loveni; Schistomeringos caeca. Gut material from selected specimens of these species was viewed with a scanning electron microscope (SEM). The Virginia Institute of Marine Science AMRAY 1000 SEM was used. Gut material was removed from each specimen and placed in a capsule with 12 micron Nucleopore filter ends. Each capsule was immersed for 10 minutes in consecutive treatments of $70 \%$; $80 \%$; $90 \%$; $95 \%$; and $100 \%$ ethanol, and then 5 minutes in acetone. The material was dried in a critical-point dryer for 5 minutes, allowed to sit for one hour, then dried for another 5 minutes. Specimens were then mounted on aluminum stubs with DAG paint, and coated with a 200 angstrom-thick coating of gold pal- 
ladium in the vacuum evaporator. The same classes of ingested material as above were utilized in analyses of this material.

Each species was classified according to feeding biology (e.g. carnivore, herbivore, detritivore). The classification scheme of Jumars and Fauchald (1977) was used. Each species was characterized by three parameters: feeding mode; motility; and functional morphology. Feeding mode includes five components: 1) surface deposit-feeder; 2) subsurface deposit-feeder; 3) suspension-feeder; 4) carnivore; and 5) herbivore. Motility includes three components: 1) motile; 2) discretely motile; and 3) sessile. "Discretely motile" means that the organism is capable of moving from place to place, but must be sessile to feed. Functiona 1 feeding morphology includes: 1) jawed; 2) tentaculate; 3) pumping; 4) soft proboscis. Each polychaete species was classified, and the classification scheme was used to characterize the areas of study.

Some investigators have expressed a concern that specimens anaesthetized with magnesium chloride might regurgitate their gut contents (Fauchald, personal communication). Specimens of Nereis lamellosa, $\underline{\text { N. }}$ succinea, Cossura soyeri, Cirratulus cf. filiformis, Polydora ligni, and Glycinde solitaria were collected near Cameron, Louisiana and ma intained in the laboratory to determine influence of magnesium chloride. The specimens were placed in Syracuse watch glasses for observation with a stereomicroscope. Using a dark field background and backlighting it was possible to determine the location of food in the gut. The specimens were then transferred to watch glasses containing iso- 
tonic magnesium chloride or to watch glasses with seawater where they could be observed for reaction to the solutions. None of the species reacted violently to the solution. None of them regurgitated any material. After 30 minutes only single specimens of $\underline{P}$. ligni and $\underline{C}$. cf. filiformis evacuated any significant part of their gut contents, which included only the posterior-most contents, passed as an apparent normal defecation.

Numerical classification (cluster analyses) was performed using the Virginia Institute of Marine Science program COMPAH (Combinatorial Polythetic Agglomerative Hierarchical Program). Log transformation $(\log X+1)$ and the Bray-Curtis similarity measure (Bray and Curtis 1957) were employed in the clustering. This similarity measure can be expressed as:

$$
s_{j k}=1-\frac{\sum_{i=1}^{n}\left|x_{j i}-x_{k i}\right|}{\sum_{i=1}^{n}\left(x_{j i}+x_{k i}\right)}
$$

where, in normal clustering, $S_{j k}$ equals the similarity between stations $j$ and $k$, and $x_{j i}$ and $x_{k i}$ equal the abundance of species $i$ and station $j$ and $k$ respectively. Flexible sorting (Lance and Williams 1967), with beta established at -0.25 was employed.

Statistical analyses in this investigation included determination of correlation coefficients for polychaete feeding biology components 
and sediment parameters. The methods used were those of the Pearson product-moment correlation coefficient (Sokal and Rohlf 1981). 


\section{RESULTS}

The results are given in three major sections: 1) polychaete feeding modes and gut contents analyses; 2) broad scale distribution patterns of polychaete feeding classes in the Middle Atlantic Bight; 3) medium scale distribution patterns of polychaete feeding classes in Areas $B$ and $E$. The first section reviews findings of the laboratory and gives literature summaries of polychaete feeding modes. General data on distributions and abundances of polychaetes collected during the BLM Middle Atlantic Bight program are also addressed in this section. These data are summarized in Table 3. Sections two and three are characterizations of habitats based on the feeding classifications of section one. A summary of laboratory analyses are included in Appendix A.

\section{Feeding Classification}

The following data result from feeding mode and gut content investigations of polychaetes collected in the Middle Atlantic Bight. Each family is discussed separately, and the study is organized alphabetically by family. Numbers of specimens dissected and a summary of gut contents identified are provided in Appendix A. Families of polychaetes for which extensive literature and substantial credible data on feeding are available (e.g. Chaetopteridae, Serpulidae, Magelonidae) have been omitted from this summary. More extensive literature sum- 


$$
\text { 它 }
$$$$
\text { 导 }
$$

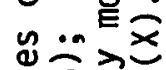$$
\text { 电的 }
$$

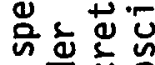$$
\text { - 멍 뇽 }
$$$$
\text { 二뿬원 }
$$$$
\text { 남 }
$$

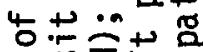$$
\text { d ñ⿻上丨。 }
$$$$
\text { 岁遂的前 }
$$

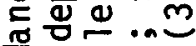$$
\text { 욛요 }
$$

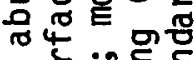

ฯ 当壬资 을

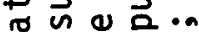
ํ..

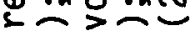
을 年

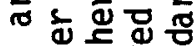
뭉

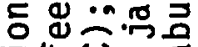
世 4 . . $\ddot{3} \pm \ddot{E} \geq$

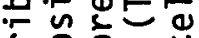
닝ㅇㅇㅇㅛ nब. ㅁํㄷㅇ

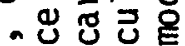
in 岁幽艺至

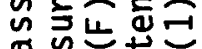
テ

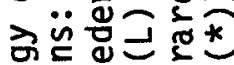
앙ㄷㅇㄴ

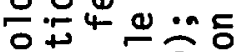

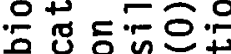

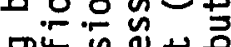
문 « \& 든

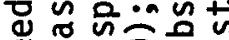

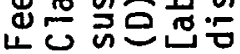

$\frac{\dot{0}}{\infty}$

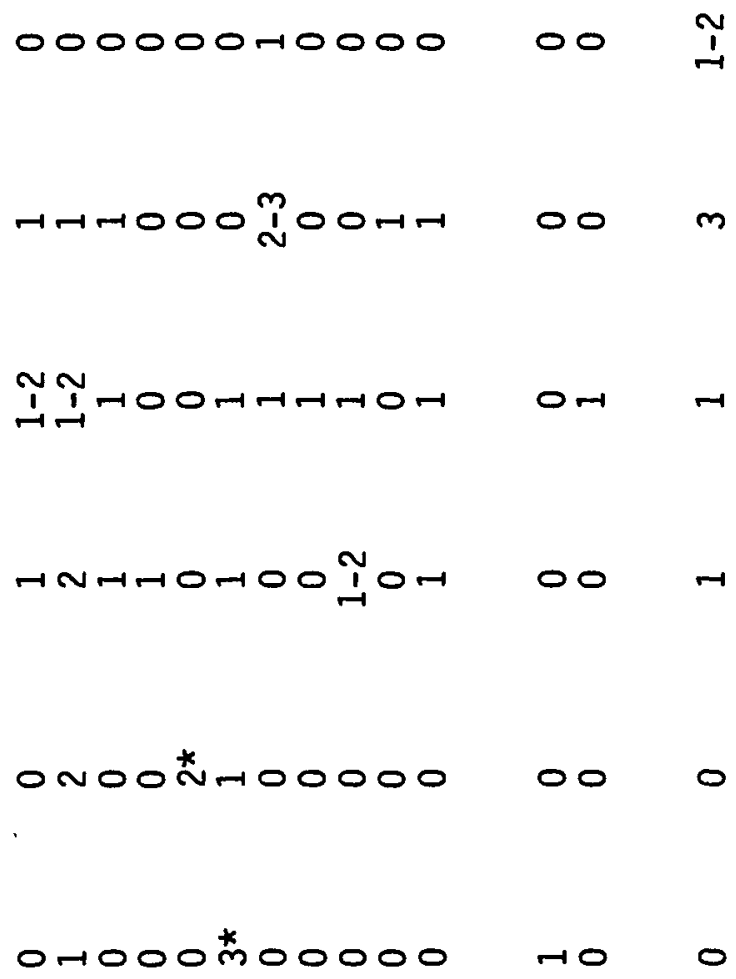

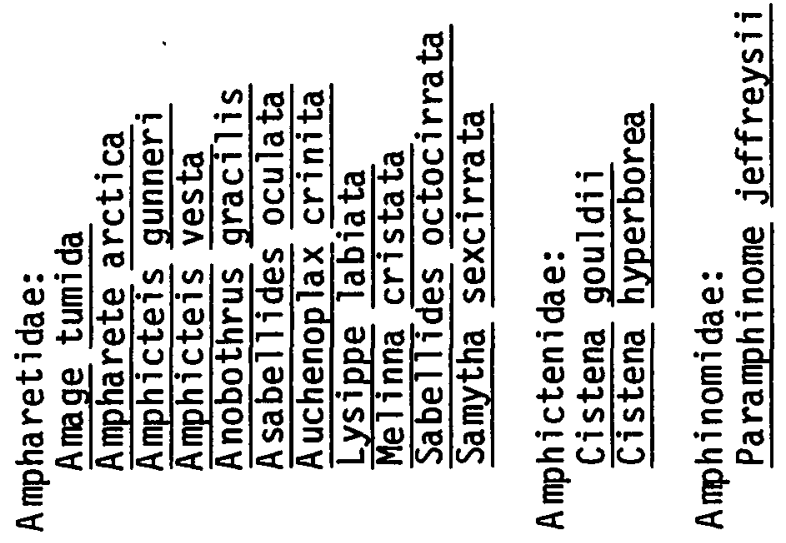




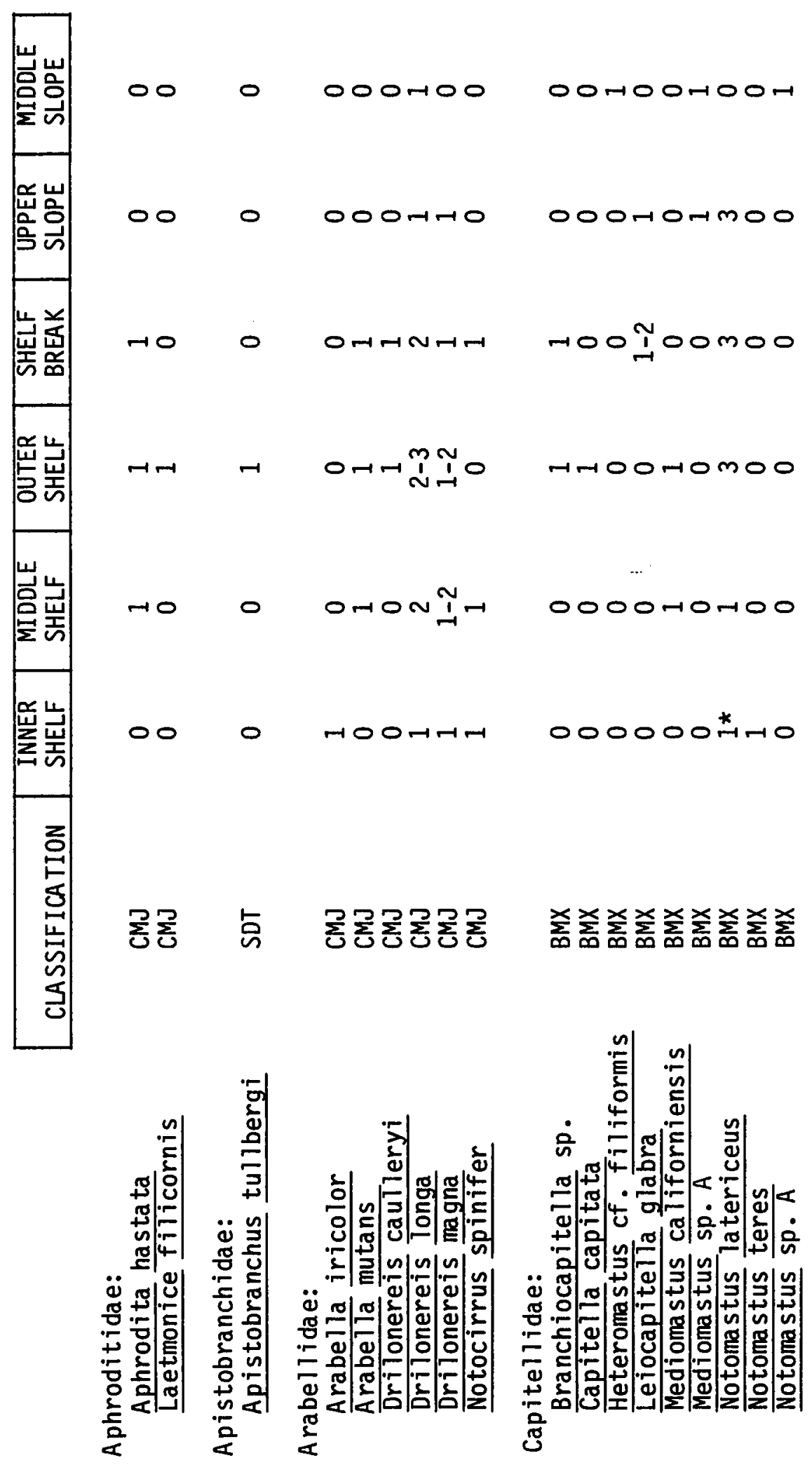




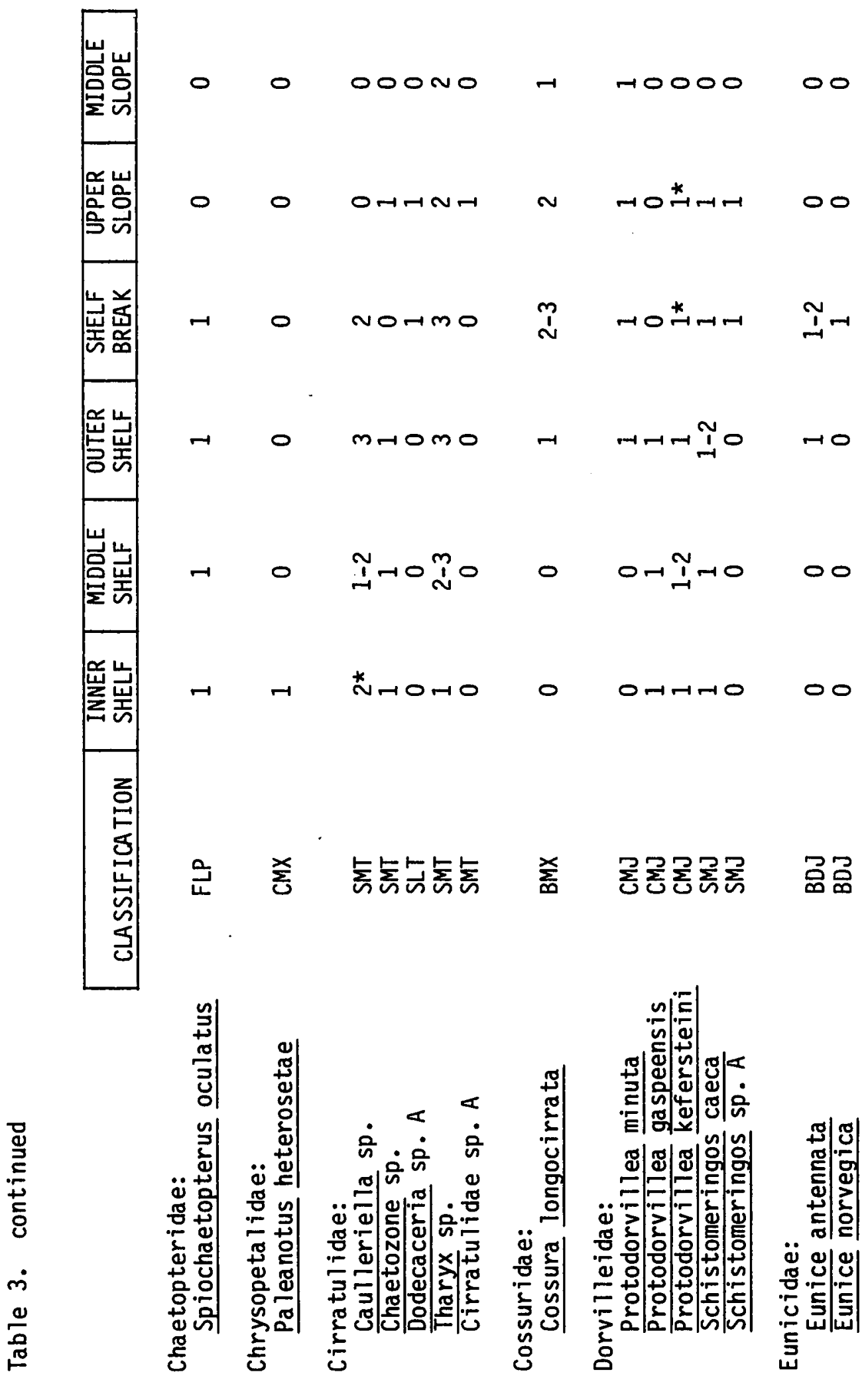




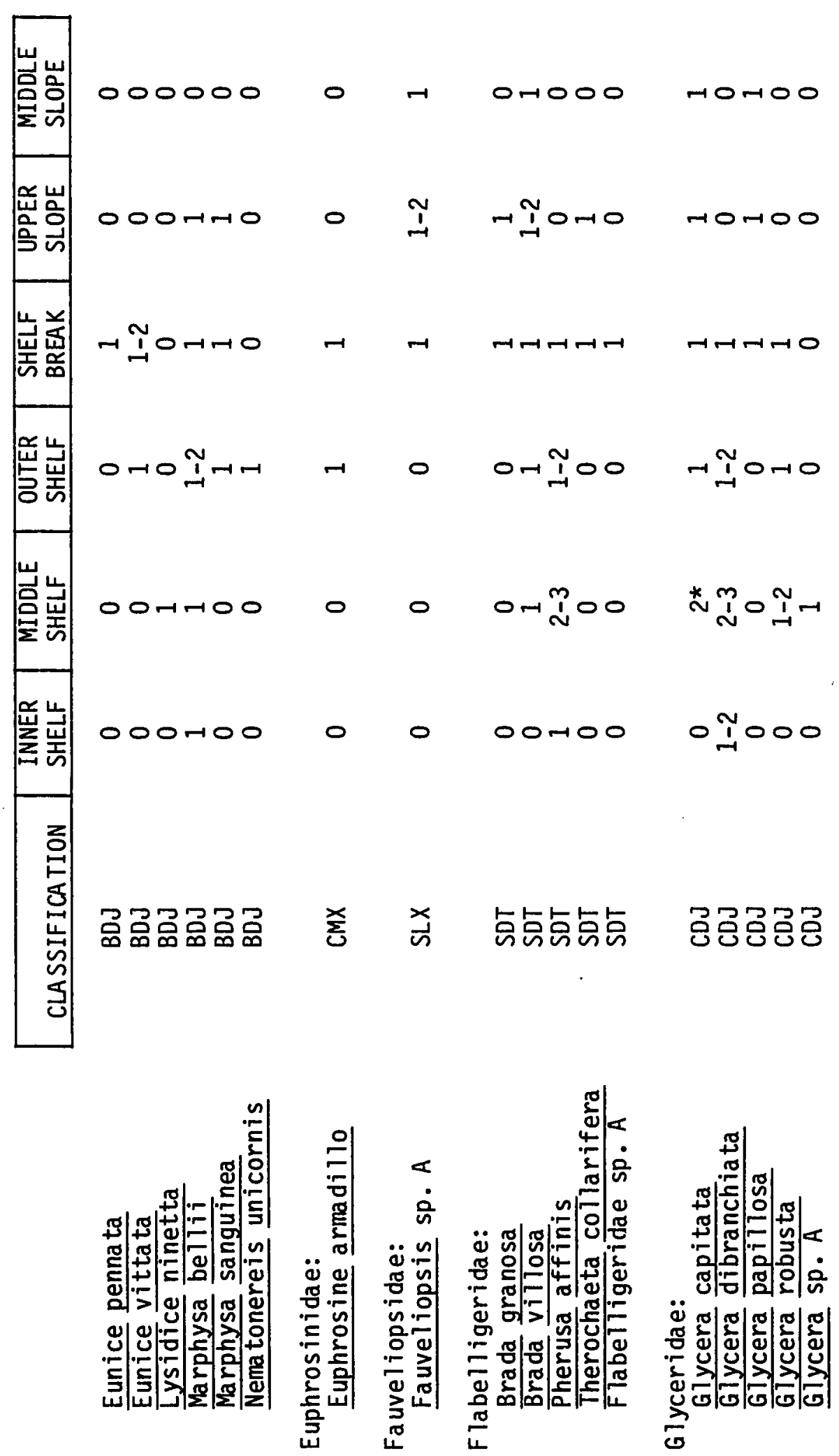




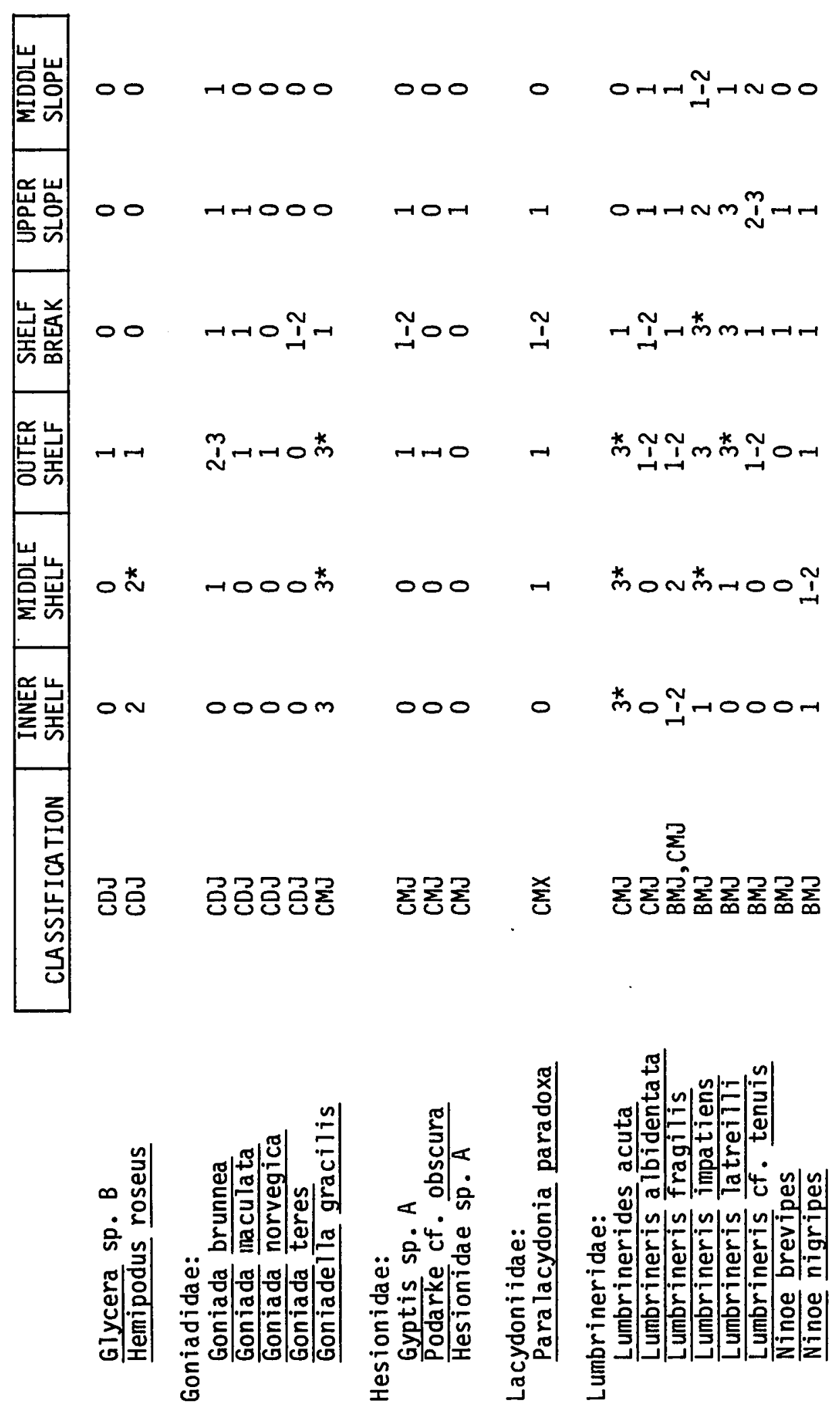



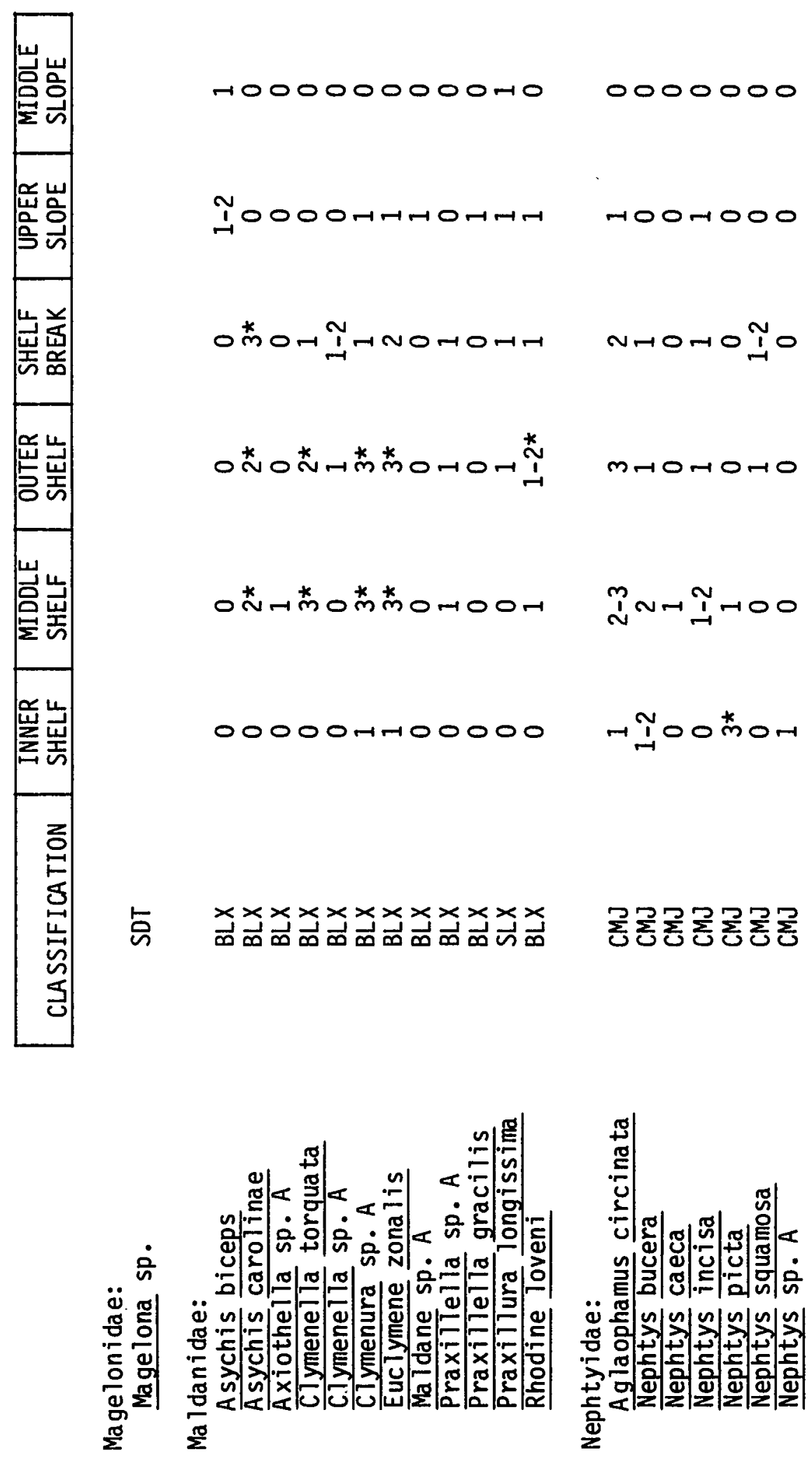


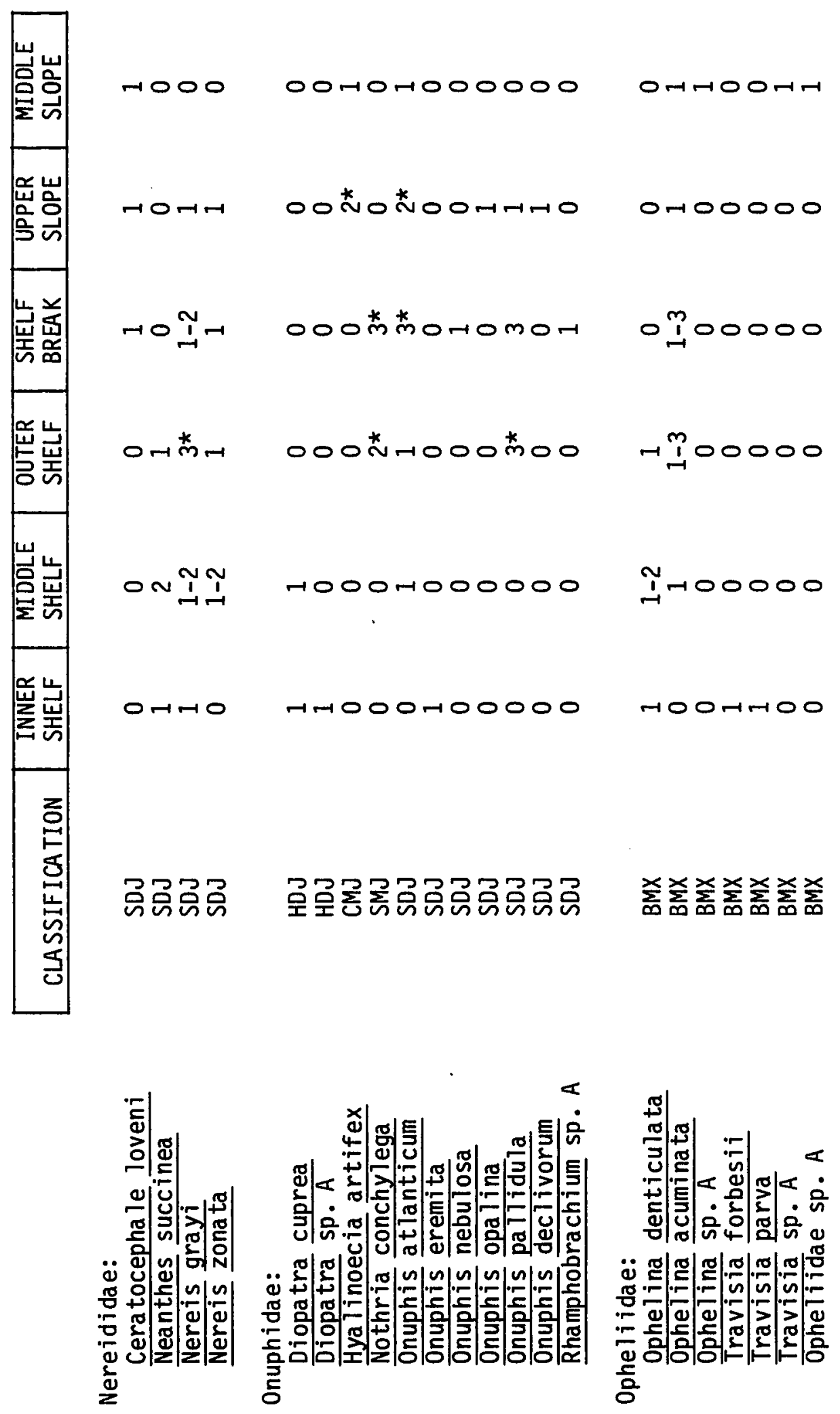



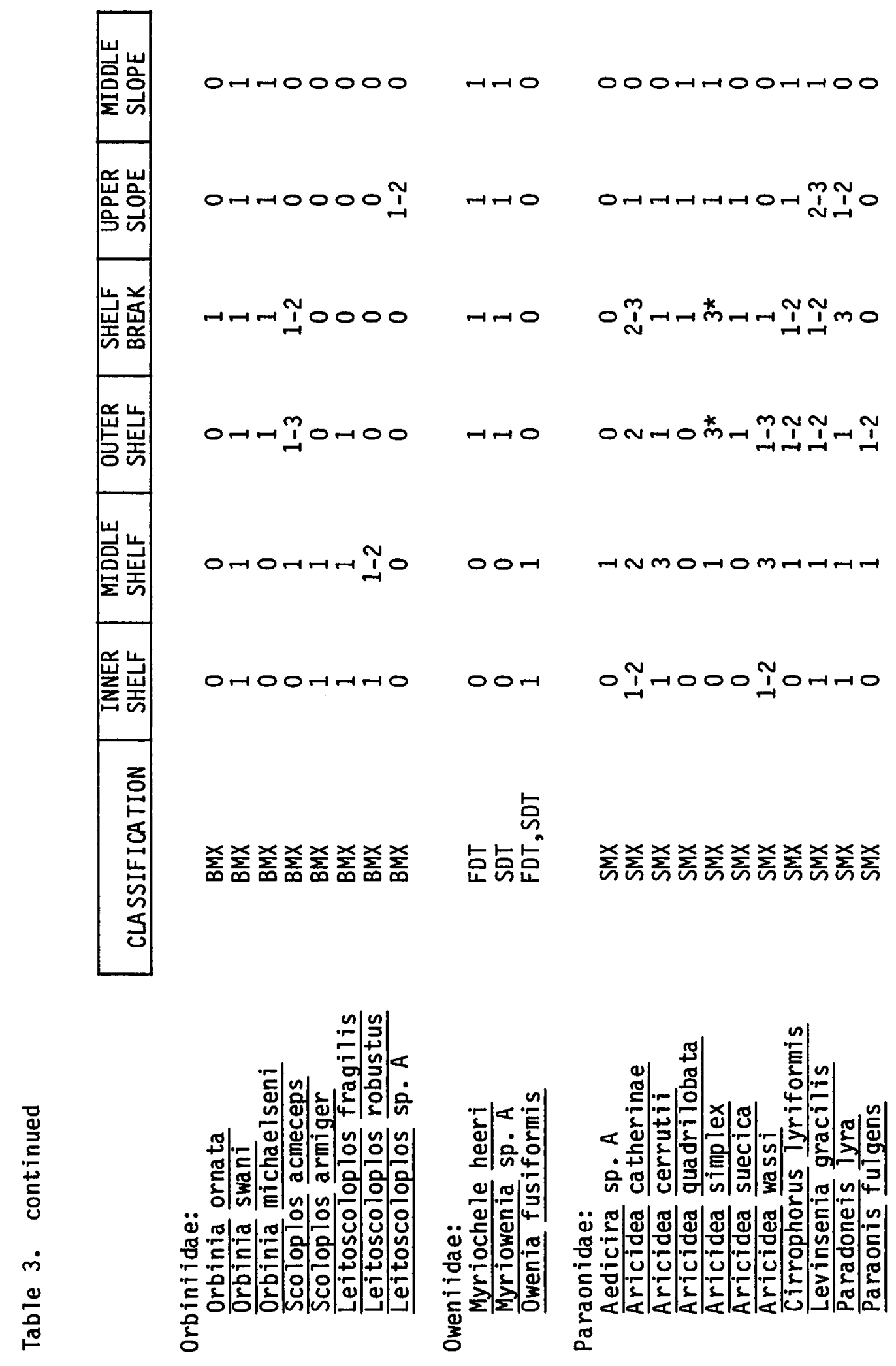
0000000000000000 H0000 मन

岩岩 业

原

这岩

000 000m0000m0000m0000 Hन

的

$\leftarrow z$

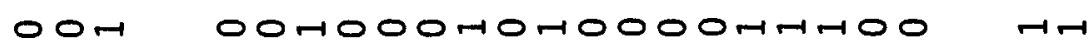

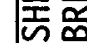

은

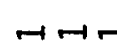

$-1+4$

10

.

(

u

풍

$-100$

$\rightarrow 0$

no

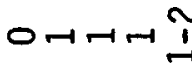

inー

00

000 Hom0-100 I0000000000 00

Z

S

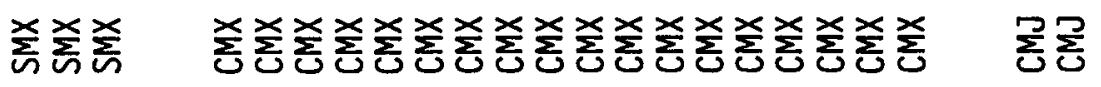

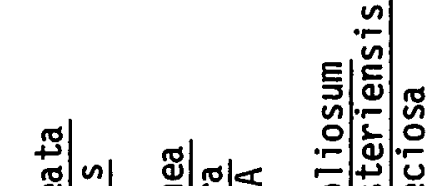

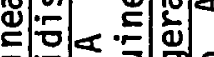

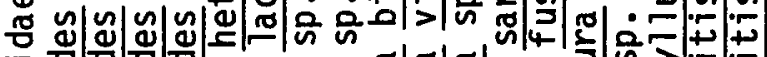

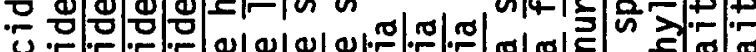

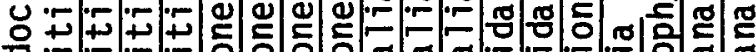

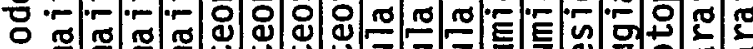
을 ᄅ

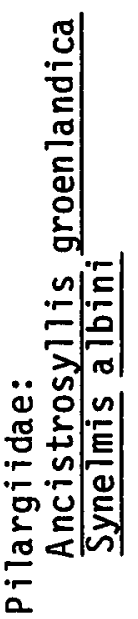



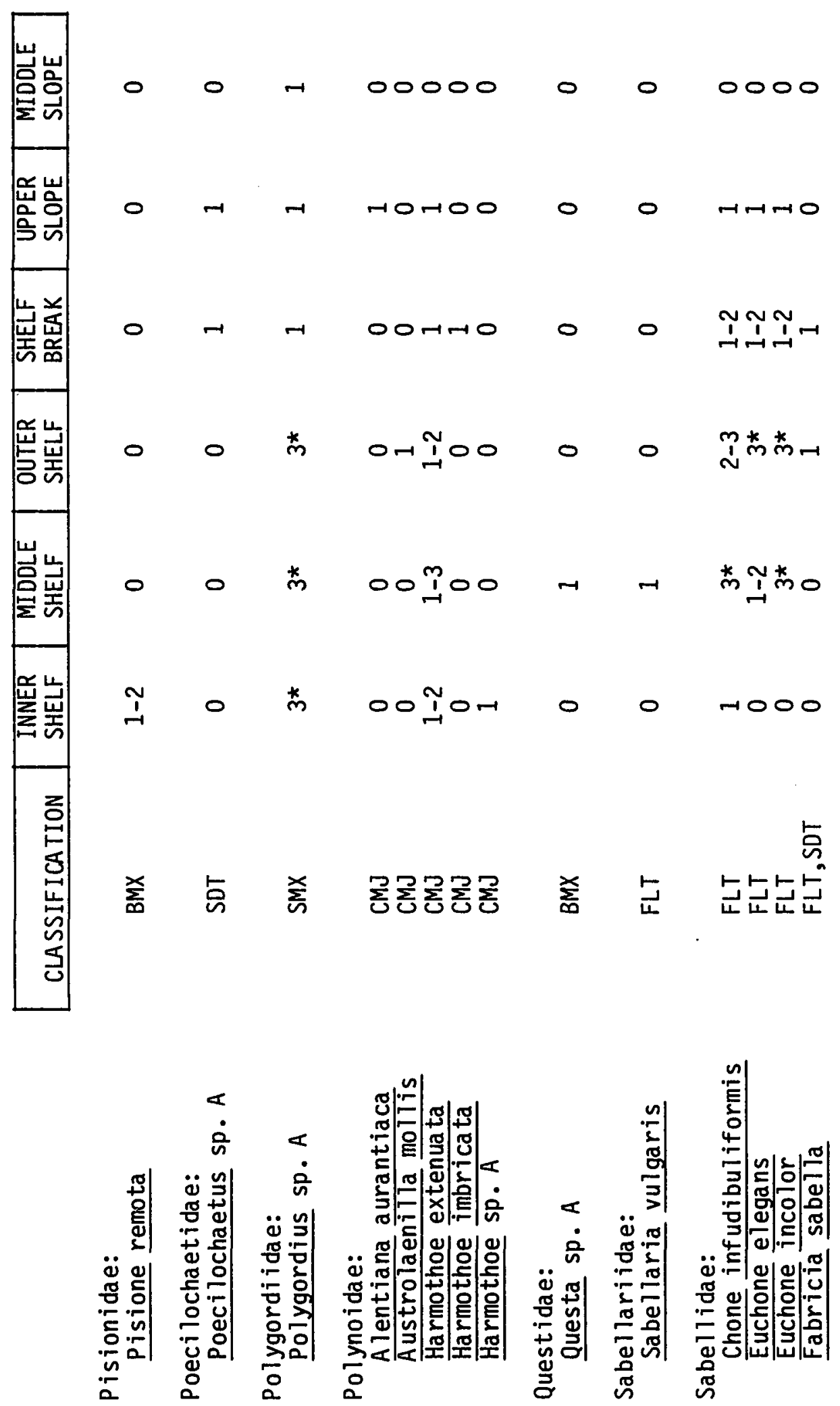


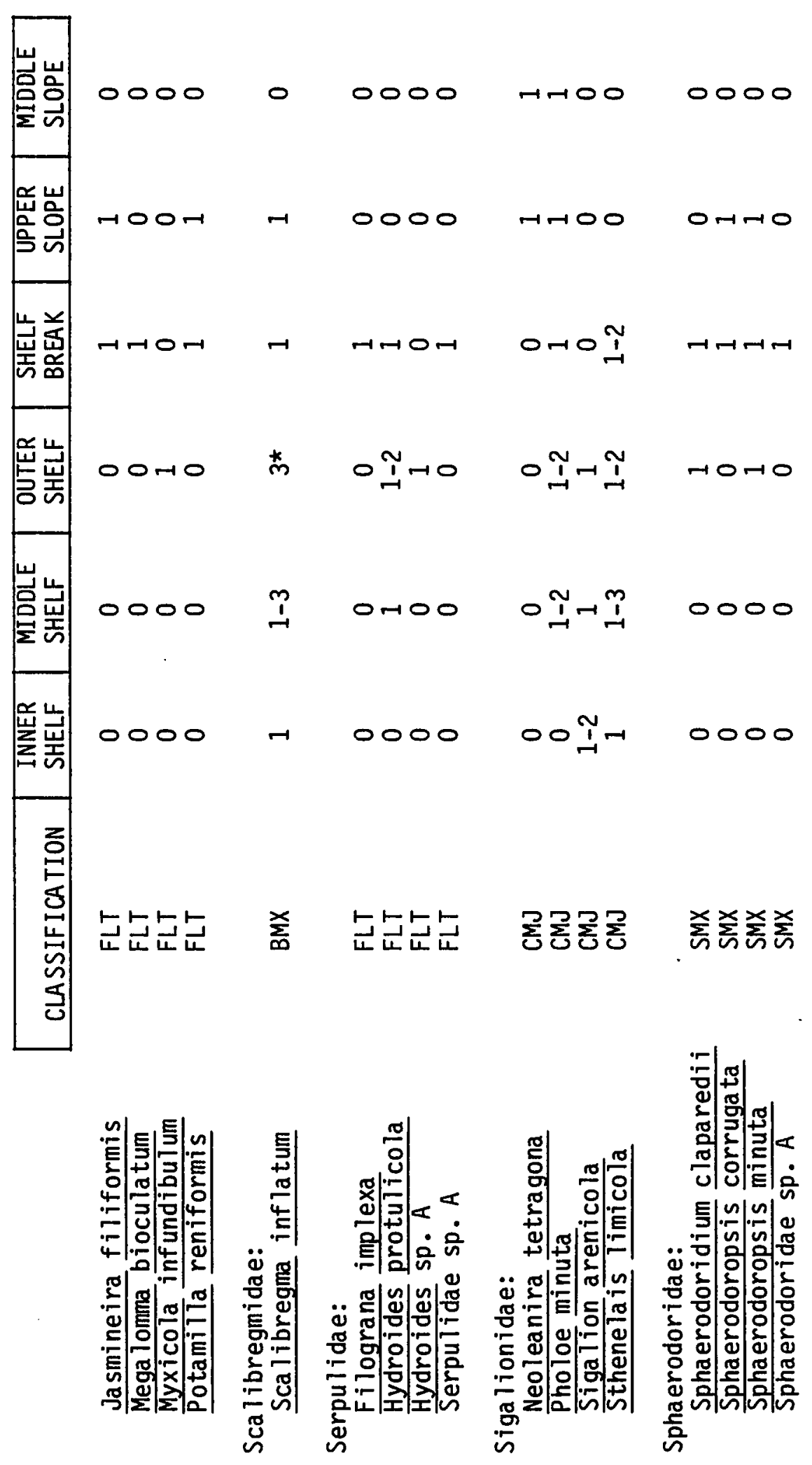




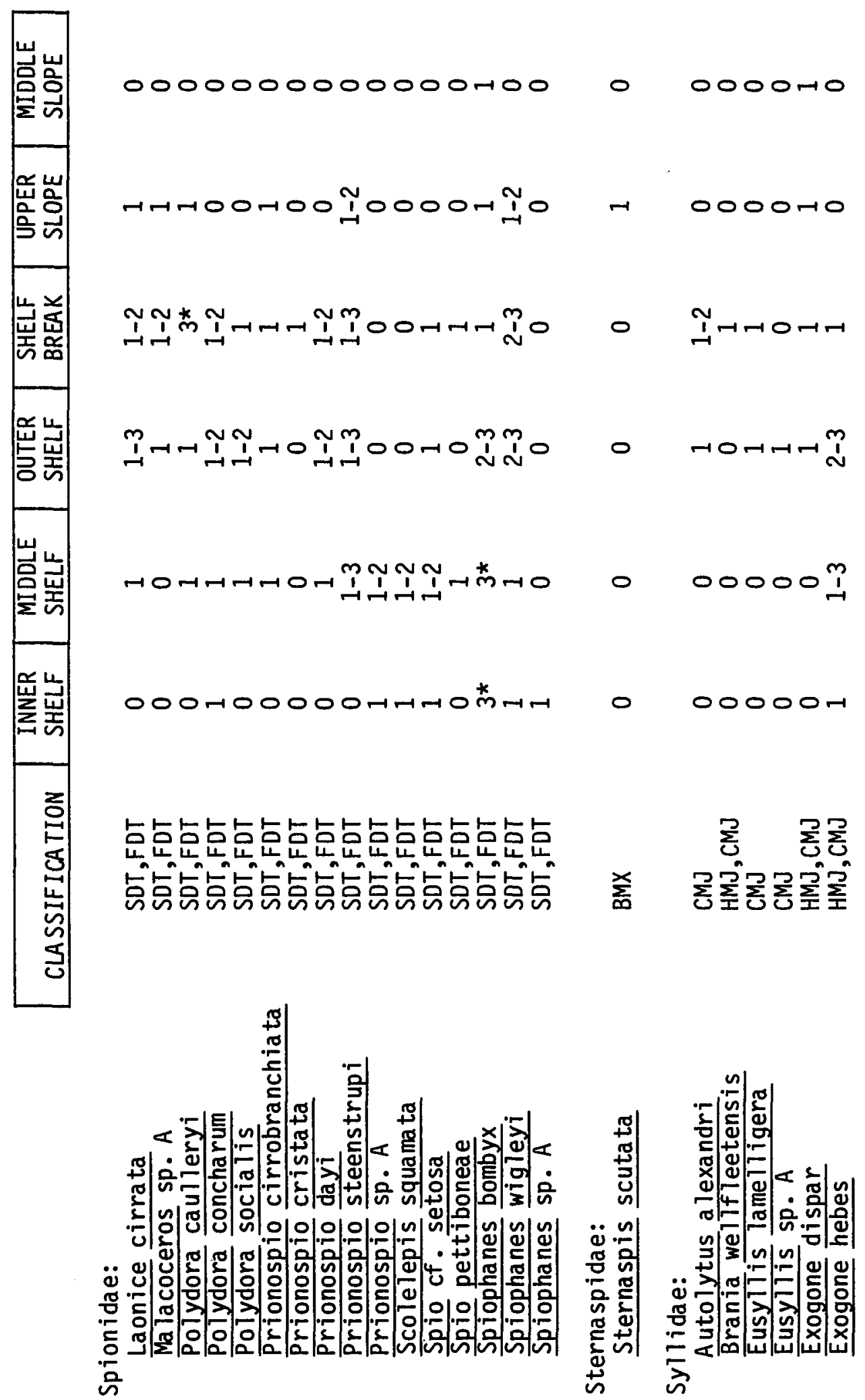




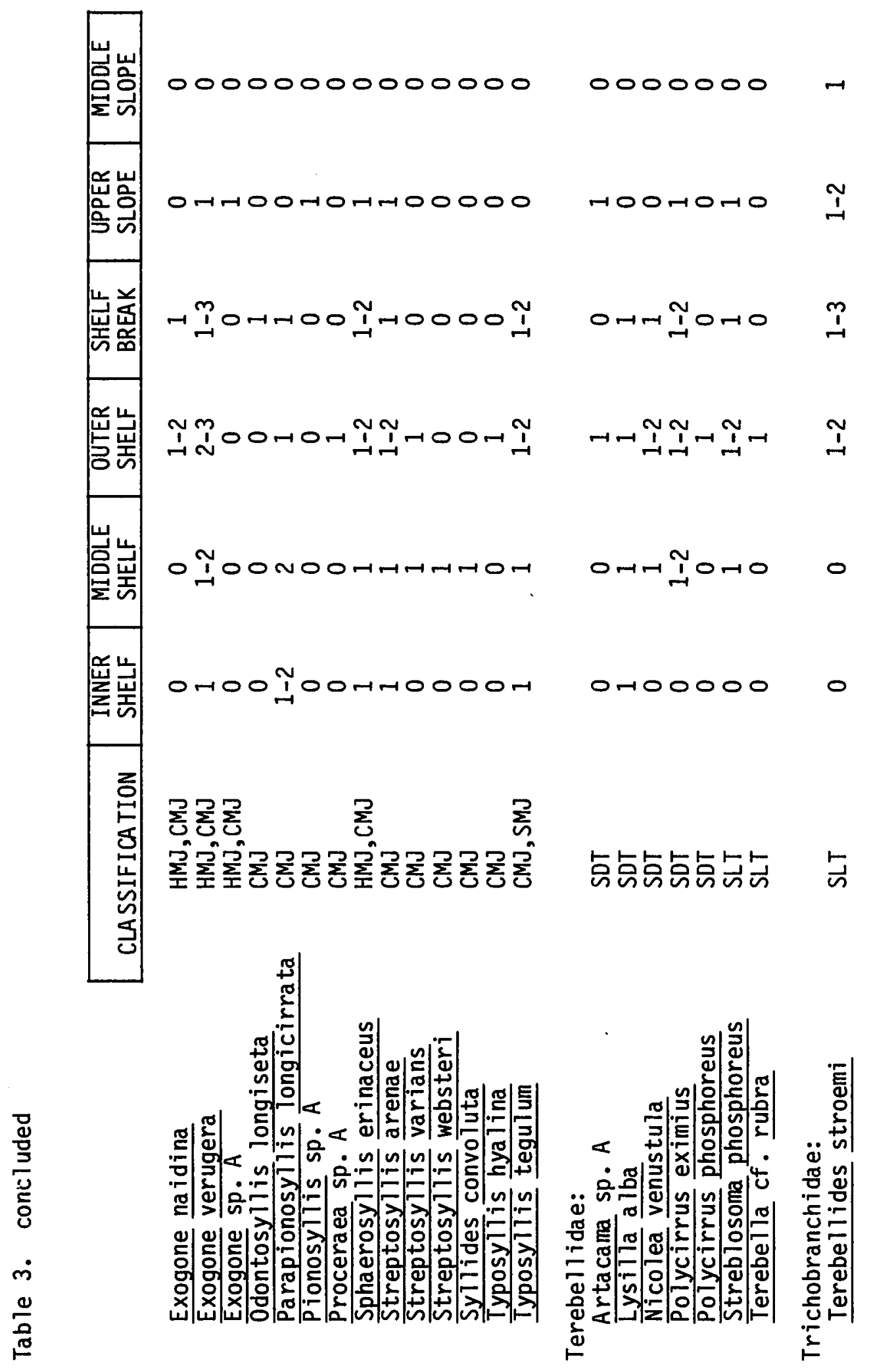


maries, including all major families of Polychaeta, are available in Fauchald and Jumars (1979).

Ampharetidae

Ampharetids are generaliy considered to be surface deposit feeders that occupy mucus-lined tubes oblique to the surface of the substratum (Yonge 1928, Dales 1963, Day 1967, Fauchald and Jumars 1979). Food is collected by ciliated buccal tentacles. Gut content analyses by Fauvel (1897) and Hessle (1925) indicate that ampharetids primarily ingest detritus. Additionally, Fauchald and Jumars (1979) hypothesized that ampharetids are selective deposit feeders, utilizing deposited material near their tube openings.

A total of 11 species of ampharetids was collected in the Middle Atlantic Bight during the present investigation:

Amage tumida Ehlers, 1887

Ampharete arctica Ma 1mgren, 1886

Amphicteis gunneri (Sars, 1835)

Amphicteis vesta Hartman, 1865

Anobothrus gracilis (Malmgren, 1866)

A sabellides oculata (Webster, 1879)

Auchenoplax crinita Ehlers, 1887

Lysippe labiata Malmgren, 1886

Melinna cristata (Sars, 1851)

Sabellides octocirrata (Sars, 1835)

Samytha sexcirrata (Sars, 1856) 
Of these, Ampharete arctica, Melinna cristata, Auchenoplax crinita, and Anobothrus gracilis occurred in moderate abundance in the Middle Atlantic Bight. All other species were rare in occurrence. Each of the more abundant species was dissected for gut content analyses, and each was filled with detritus. Ampharete arctica and Asabellides gracilis both form loosely-packed fecal pellets. The pellets included mostly unidentifiable detritus and numerous small centric diatoms and diatom pieces. Guts of Auchenoplax crinata were filled with detritus including silt and clay particles, some fragments of diatoms, and a few coarse sand grains. ‥ cristata, like $\underline{A}$. crinata, does not form fecal pellets. It apparently ingests sediment. Guts were filled with particles of sediment from medium quartz sand $(0.4 \mathrm{~mm}$ diameter $)$ to silt and clay. This ingested material included numerous small centric diatoms (usually 10 to $50 \mu \mathrm{m}$ diameter) and diatom fragments, pieces of dinoflagellates, and an abundance of unidentifiable detritus. Nothing observed in the material ingested by these species indicated any feeding mode other than surface deposit feeding.

\section{Amphinomidae}

Amphinomids are usually considered to be mobile carnivores that feed on Anthozoa (Ebbs 1966), sponges and hydroids (Dales 1963), or any of numerous other sessile invertebrates including other species of polychaetes (Day 1967). They lack jaws, but have muscular cushion-like lips possibly used for sucking. Many amphinomids (e.g. Hermodice, Eurythoe) are active browsers in tropical reefs where they seek out 
prey. Others (e.g. Paramphinome, Pseudeurythoe) are associated with fine sediments where they may occur at the sediment surface, or in burrows at depth. There is some recent evidence that Eurythoe (Kudenov 1974) and, possibly, Chloeia (Fauchald and Jumars 1979) feed more on carrion than live prey.

Paramphinome jeffreysii (McIntosh 1868) was the only amphinomid collected during this study. It occurred at many outer shelf and shelf-break stations, and in abundance on the continental slope (e.g. stations $H 1, H 2, J 1, J 2, K 6, L 6)$. Gut contents analyses revealed that all specimens dissected had completely empty guts. These data, though inconclusive, are generally considered indicative of a predatory life history wherein animal prey are relatively infrequently consumed and rapidly digested. For this investigation $\underline{P}$. jeffreysii is considered a carnivore.

\section{Aphroditidae}

Early investigations of feeding by aphroditid species concluded that they are slow, mobile carnivores armed with chitinized jaws and a muscular proboscis. Blegvad (1914) found that Aphrodita aculeata feeds on nemerteans and sabellid and terebellid polychaetes. Hunt (1925), who examined numerous specimens of $\underline{A}$. aculeata from four separate areas near Plymouth, England, reported numerous polychaete species as prey including many terebellids and specimens of amphictenids, lumbrinerids, polynoids, and nereids. They also contained crustaceans and a nemertean. Recently, Mettam (1980) recounted an observation by Gunnar 
Thorson of $\underline{A}$. aculeata feeding on a large Nereis virens, which contradicts earlier assumptions that aphroditids should be slow-moving and capable of feeding only on sessile or discretely motile prey. Laboratory experiments by Mettam corroborate Thorson's observations. Mettam found that both Nereis diversicolor and Nephtys hombergi were taken when various potential prey were offered.

Both Aphrodita hastata Moore, 1905 and Laetmonice filicornis Kinberg, 1855 were collected during the present study. Both species occurred throughout the study area, however, neither species was collected in abundance. L. filicornis was more common in collections made by a sma 11 biology trawl than $\underline{A}$. hastata, possibly due to a difference in burrowing habits of the two species at the sediment-water interface. The guts of most specimens examined were empty. Three specimens of $\underline{A}$. hastata, however, contained remains of polychaetes. Each of these three specimens also had ingested medium quartz sand grains (15 to 30 $\mu m$ diameter) with the prey. One specimen contained nereid setae and a well digested mass of tissue. The other two specimens each contained. remains of a single Glycera dibranchiata. Based on these and historical data, both $\underline{A}$. hastata and $\underline{\text { L. filicornis }}$ are considered carnivores.

\section{Arabellidae}

Arabellids are elongate, cylindrical eunicidans usually with well developed jaws. Some species are parasitic in other polychaetes, especilly in eunicids, syllids, onuphids, and terebellids (Pettibone 
1963). The parasitic species usually have a reduced jaw apparatus. Most species, however, are free-living active burrowers. Most. authors agree that the free-living burrowers are carnivorous as adults. (Pettibone 1957, 1963, Southward 1957, Day 1967), though many may be parasitic as juveniles (Pettibone 1957, Emerson 1974). Sanders et al. (1962) however, found evidence that specimens of Drilonereis longa collected in Barnstable Harbor, Massachusetts ingested sand. This led Fauchald and Jumars (1979) to categorize the family Arabellidae as both carnivores and surface deposit feeders.

Six species of arabellids were collected in the Middle Atlantic Bight during the present study:

Arabella iricolor (Montagu, 1804)

A rabella mutans (Chamberlin, 1919)

Drilonereis longa Webster, 1879

Drilonereis magna Webster and Benedict, 1887

Drilonereis caulleryi Pettibone, 1957

Notocirrus spiniferus (Moore, 1906)

D. longa and ‥ magna occurred throughout the study area, though only D. longa occurred in abundance. Gut contents analyses of numerous specimens of these species and of Arabella mutans indicated a carnivorous life style. Only empty guts were found in dissected specimens of $\underline{A}$. mutans, but one specimen of $\underline{D}$. magna contained unidentifiable remains of a crustacean, and $\underline{D}$. longa specimens were either empty or contained tightly bound mucus and sand masses. These masses included no prey or prey components, but may be indicative of carnivory, since 
similar masses were regularly found in clearly predatory species (e.g. Goniadidae, some Lumbrineridae). Sand masses may represent sediment which remains in the gut of prey following digestion or an unsuccessful feeding attempt which may account for observations made by Sanders et a 1. (1962) of sand in the gut of D. longa.

\section{Capitellidae}

Capitellids are simple in morphology, generally rounded in crosssection, lacking appendages on the prostomium. A11 feed on detritus by everting a papillose, sac-like pharynx (Fauchald and Jumars 1979).

A total of 9 species was collected during this investigation:

Branchiocapitella sp.

Capitella capitata (Fabricius, 1780)

Heteromastus cf. filiformis (Claparede, 1864)

Leiocapitella glabra Hartman, 1965

Mediomastus californiensis Hartman, 1944

Mediomastus sp. A

Notomastus latericeus Sars, 1850

Notomastus teres Hartman, 1965

Notomastus sp. A

Notomastus latericeus was the most abundant capitellid collected in the Middle Atlantic Bight. It occurred throughout much of the study area, often as one of the ten most abundant macroinvertebrates at a collection site (e.g. stations A1, A2, B3, E2, E4). Species of 
Mediomastus were most abundant where finer sediments occurred (e.g. stations $H 1, H 2, I 4, J 2)$.

A 11 of the above species are motile deposit feeders that ingest material as they move through the sediment. Capitella capitata, Heteromastus filiformis, Notomastus latericeus, and probably the other species listed above, also all build tubes (Fauchald and Jumars 1979). Nothing in the present investigation indicated any behavior other than deposit feeding. Species that were dissected (N. latericeus and $\underline{M}$. californiensis) were filled with detritus and fine sediments, and lacked large diatoms present in deposit feeders of some other families (e.g. Eunicidae).

\section{Dorvilleidae}

Dorvilleids are motile polychaetes with well-developed jaws, prostomial appendages, and parapodia. The investigators disagree on the food and feeding mode of these worms. Day (1967) listed Dorvillea (now Schistomeringos, in part) as carnivorous, though earlier investigations (Hempelmann 1931, Yonge 1954) reported that guts of Schistomeringos rudolphi included algae and detritus. Schistomeringos neglecta and Protodorvillea kefersteini are known to be carnivores (Pearson 1971, Rasmussen 1973, Wolff 1973). Fauchald and Jumars (1979) concluded that dorvilleids are all facultative carnivores, but can survive on plant material.

Five species of dorvilleids were collected during this investigation: 
Protodorvillea minuta Hartman, 1965

Protodorvillea gaspeensis Pettibone, 1961

Protodorvillea kefersteini (McIntosh, 1869)

Schistomeringos caeca (Webster and Benedict, 1884)

Schistomeringos $\mathrm{sp} . \mathrm{A}$

Both $\underline{P}$. kefersteini and $\underline{S}$. caeca occurred in low abundance across the shelf. Schistomeringos sp. A and P. minuta were limited to outer shelf and slope habitats (e.g. stations J1, K6, L5, L6). P. gaspeensis was never collected in abundance. It occurred rarely in inner, middle, and outer shelf habitats.

Guts were empty in specimens of all the above species except Schistomeringos caeca. Specimens of this species were filled with amorphous detritus, fine sediments, foram tests, and a few diatoms. The forams and diatoms appeared to be only empty tests and frustules rather than live organisms. $\underline{\text { s. }} \underline{\text { caeca }}$ is here considered a detritivore. All other species are considered carnivores.

Eunicidae

Eunicids have well-developed maxillae and mandibles, parapodia, and prostomial appendages. The jaw apparatus is eversible and muscular. They occupy diverse habitats, and depending on the species, may be tubicolous, free-living, or change to a tubicolous life style after being free-living as juveniles (Day 1967, Fauchald and Jumars 1979). 
Investigations of Eunice aphroditois (Hempelmann 1931, Evans 1971) and E. tubifex (Day 1967) indicate a carnivorous life style. Other Eunice are known to feed on carrion (Mortensen 1922). Palola viridis ingests red algae and sponges (Hauenschild et al. 1969). Other tropical species (e.g. P. paloloides, E. schemacephala) may ingest coral sediment or corallinaceous algae (Ebbs 1966, Day 1967, Fauchald 1970). Literature on other genera and species is either conflicting or lacking.

Eight species of eunicids were collected in this study:

Eunice antennata (Savigny, 1820)

Eunice norvegica (Linnaeus, 1767)

Eunice pennata (Muller, 1776)

Eunice vittata (delle Chiaje, 1828)

Lysidice ninetta Audouin and Mi Ine-Edwards, 1833

Marphysa bellii (A udouin and Milne-Edwards, 1833)

Marphysa sanguinea (Montagu, 1815)

Nema tonereis unicornis (Grube, 1840)

M. bellij occurred in low to moderate abundance across the shelf. It was most abundant in outer shelf habitats (e.g. stations E3, E4, F1). Only single specimens of $\underline{E}$. norvegica, $\underline{N}$. unicornis, and $\underline{L}$. ninetta were collected; these species have not been included in the gut content analyses. No complete specimens of $\underline{M}$. sanguinea were collected; therefore, it too was eliminated from dissection analyses, but, as have all species collected, has been included in the distribution analyses. $\underline{E}$. antennata and $\underline{E}$. pennata occurred only rarely in the study area, but 
have been included in analyses. Both were limited to outer shelf and shelf break habitats. E. vittata occurred rarely on the outer shelf and was moderately abundant at the shelf break.

Only two complete specimens of Eunice antennata and $\underline{E}$. pennata were available for dissection. Both species included unidentifiable detritus, a few large sand grains (250 to $500 \mu \mathrm{m}$ ), but no large diatoms or other plant material. One specimen of $\underline{E}$. pennata contained a fecal pellet, perhaps ingested with other particulate material. Both species are classified as deposit feeders.

Twenty-one specimens of Eunice vittata were dissected. Fecal pellets were removed from two of the specimens for examination under SEM. Analyses under light microscopy revealed that the fecal pellets contained mostly detritus, occasionally some diatoms or other plant material, and some fine sand (100 to $125 \mu \mathrm{m})$. Very few whole diatoms were observed. The fecal pellets selected for observation under SEM included one composed primarily of detritus, and two that contained numerous diatoms. The "typical" pellet (Figure 4) included mostiy fine amorphous material, a few sand grains (50 to $60 \mu \mathrm{m}$ ), and a few small diatoms (10 to $50 \mu \mathrm{m}$ ) that were probably ingested incidentally. The other two pellets were almost exclusively composed of centric diatoms (Figures 5 and 6 ). One of the two "atypical" pellets included a $100 \mu \mathrm{m}$ piece of plant material (Figure 7) and many small (less than $10 \mu \mathrm{m}$ ) coccoliths (Figure 8 ). The centric diatoms in the two pellets ranged in size from less than $10 \mu \mathrm{m}$ to one equalling $175 \mu \mathrm{m}$. No pennate diatoms at all were observed. Despite the presence of diatoms and 
Figure 4. Scanning electron micrograph of gut contents of Eunice vittata. Diatom is at center and cocolith is at upper right. 


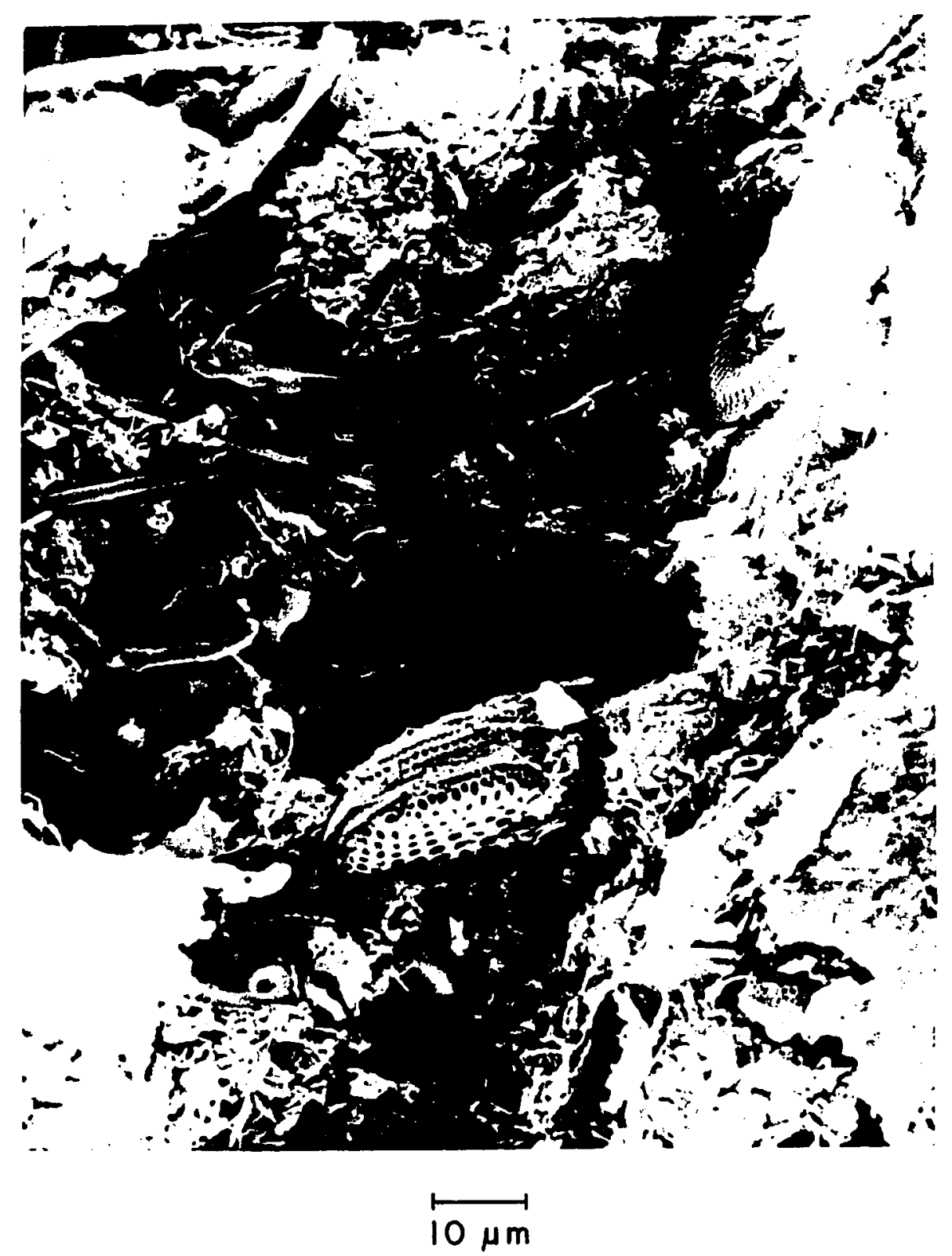


Figure 5. Scanning electron micrograph of fecal pellet of Eunice vittata. Centric diatoms are at lower right and near the center. 


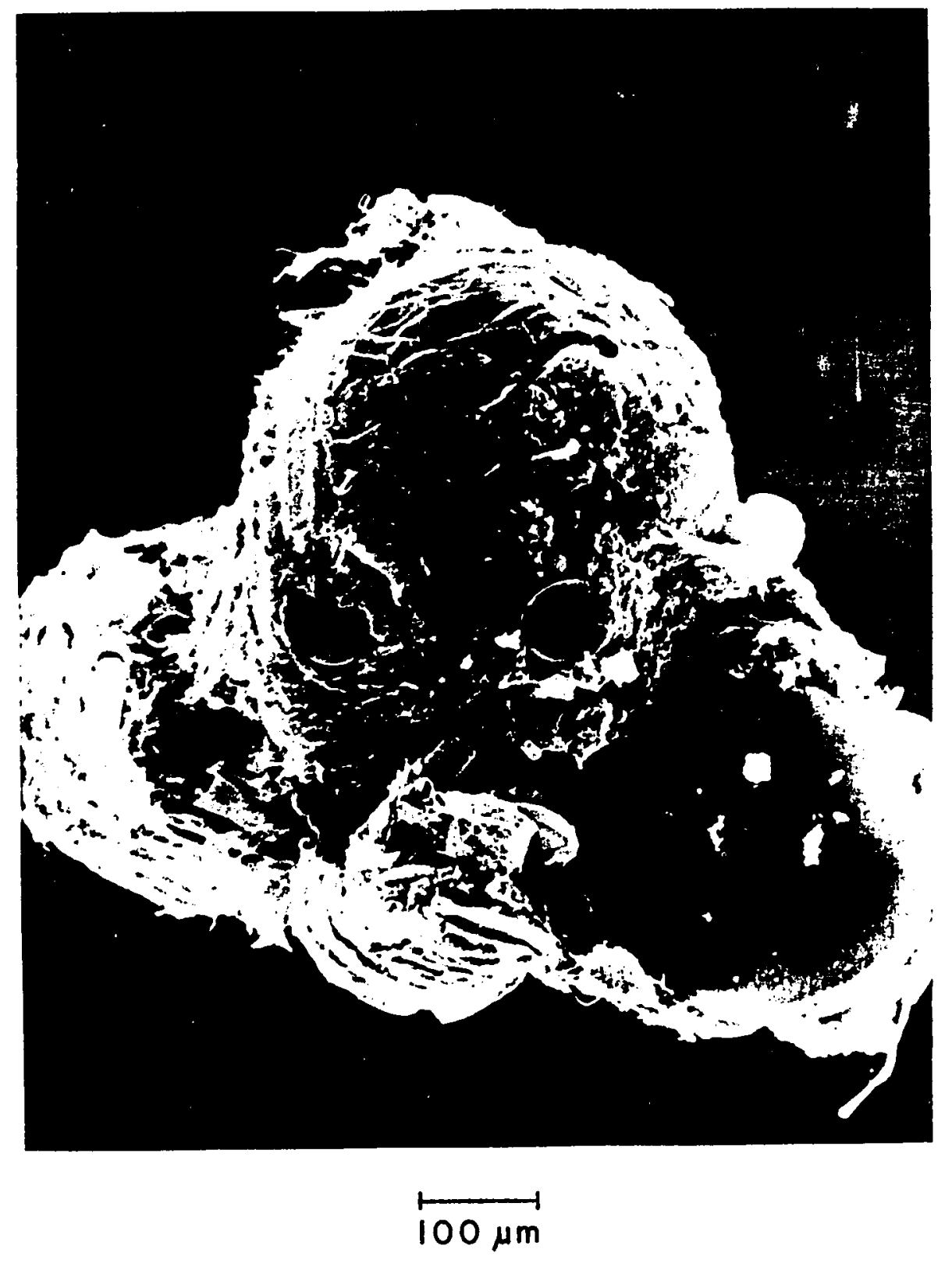


Figure 6. Scanning electron micrograph of centric diatom (Coscinodiscus sp.) in gut of Eunice vittata. 


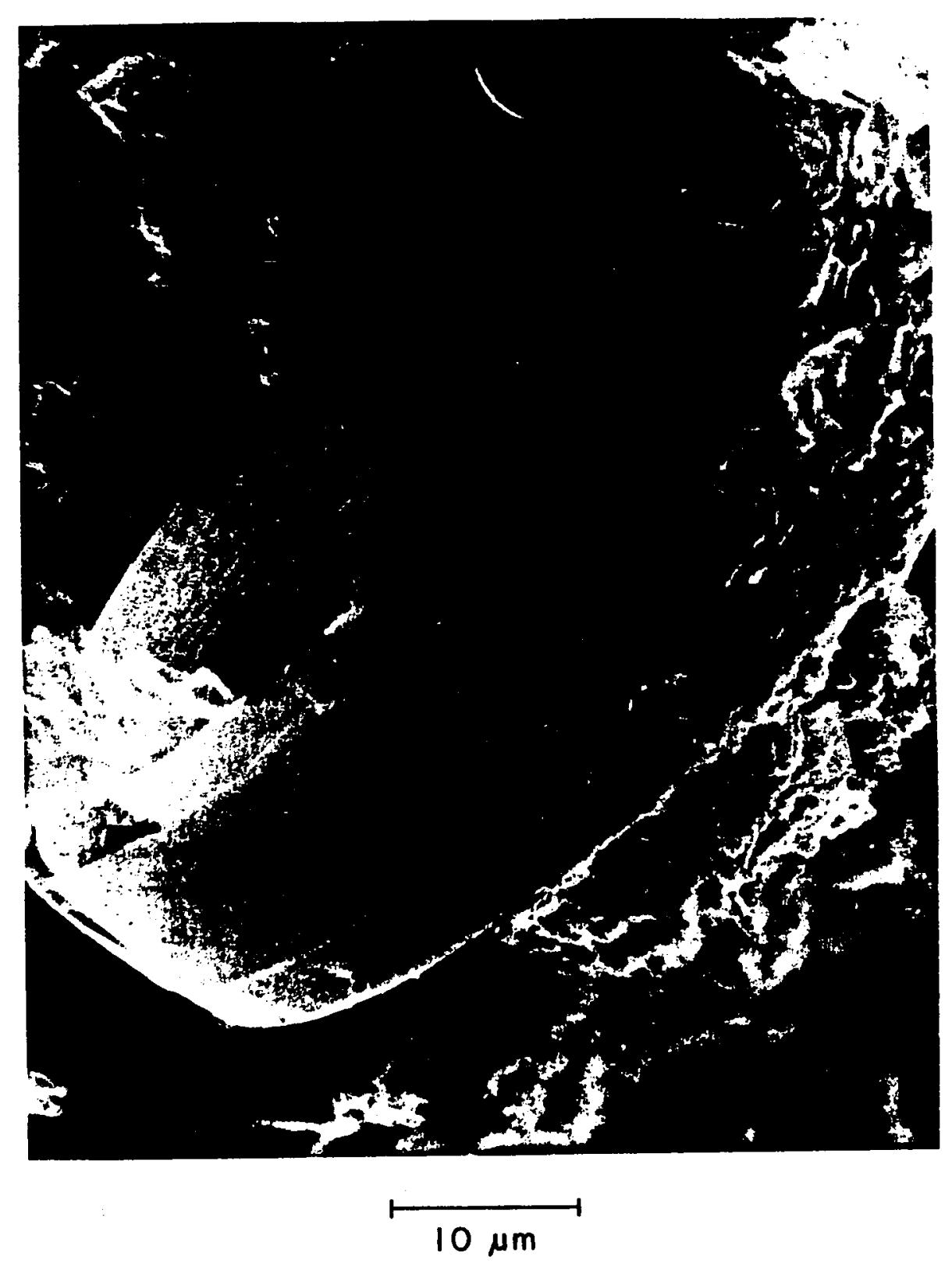


Figure 7. Scanning electron micrograph of gut contents of Eunice vittata. Plant material extends from lower left to upper right. 


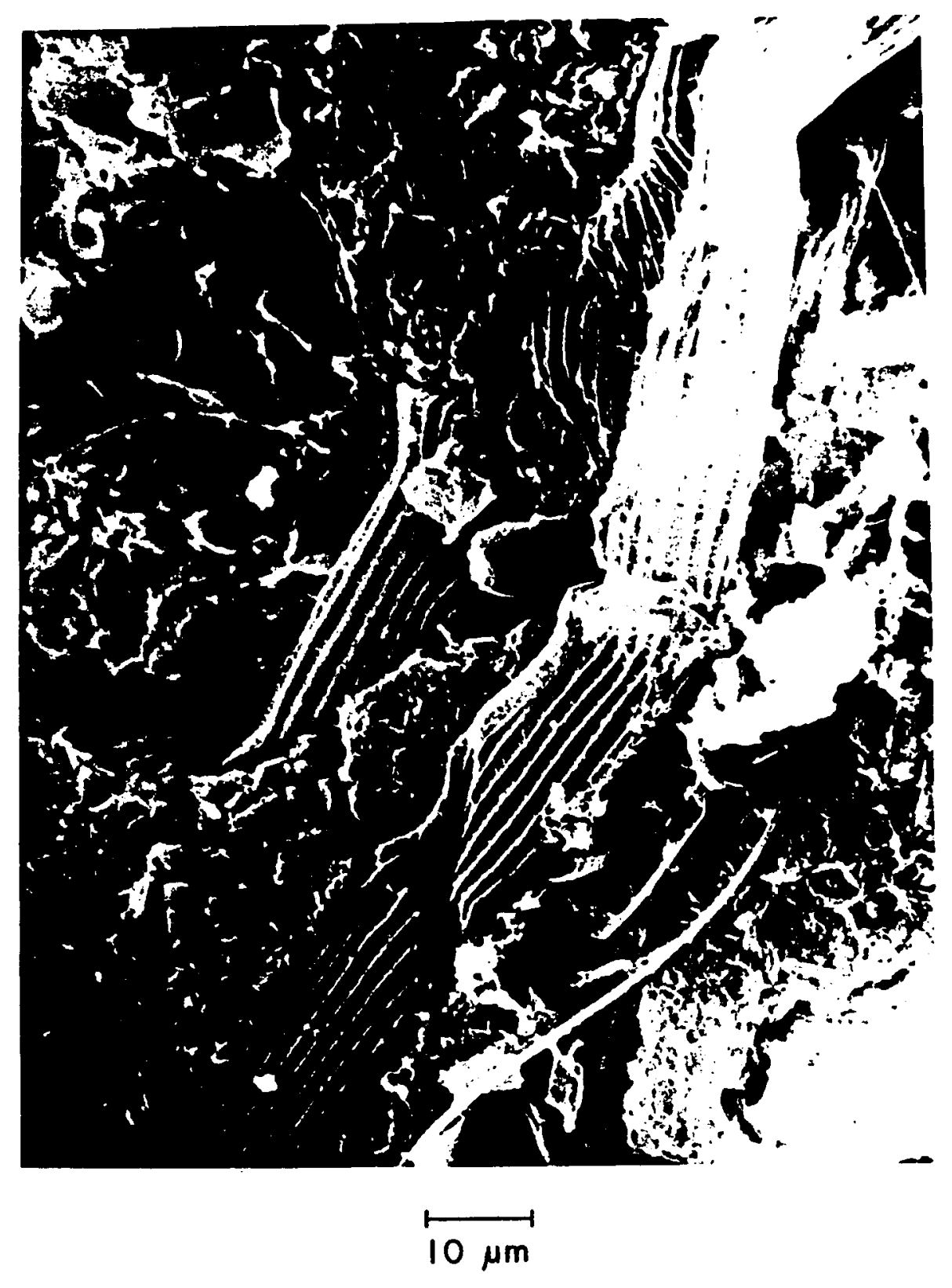


Figure 8. Scanning electron micrograph of gut contents of Eunice vittata. Centric diatoms are at lower right and upper left. Two coccoliths are at left center. 


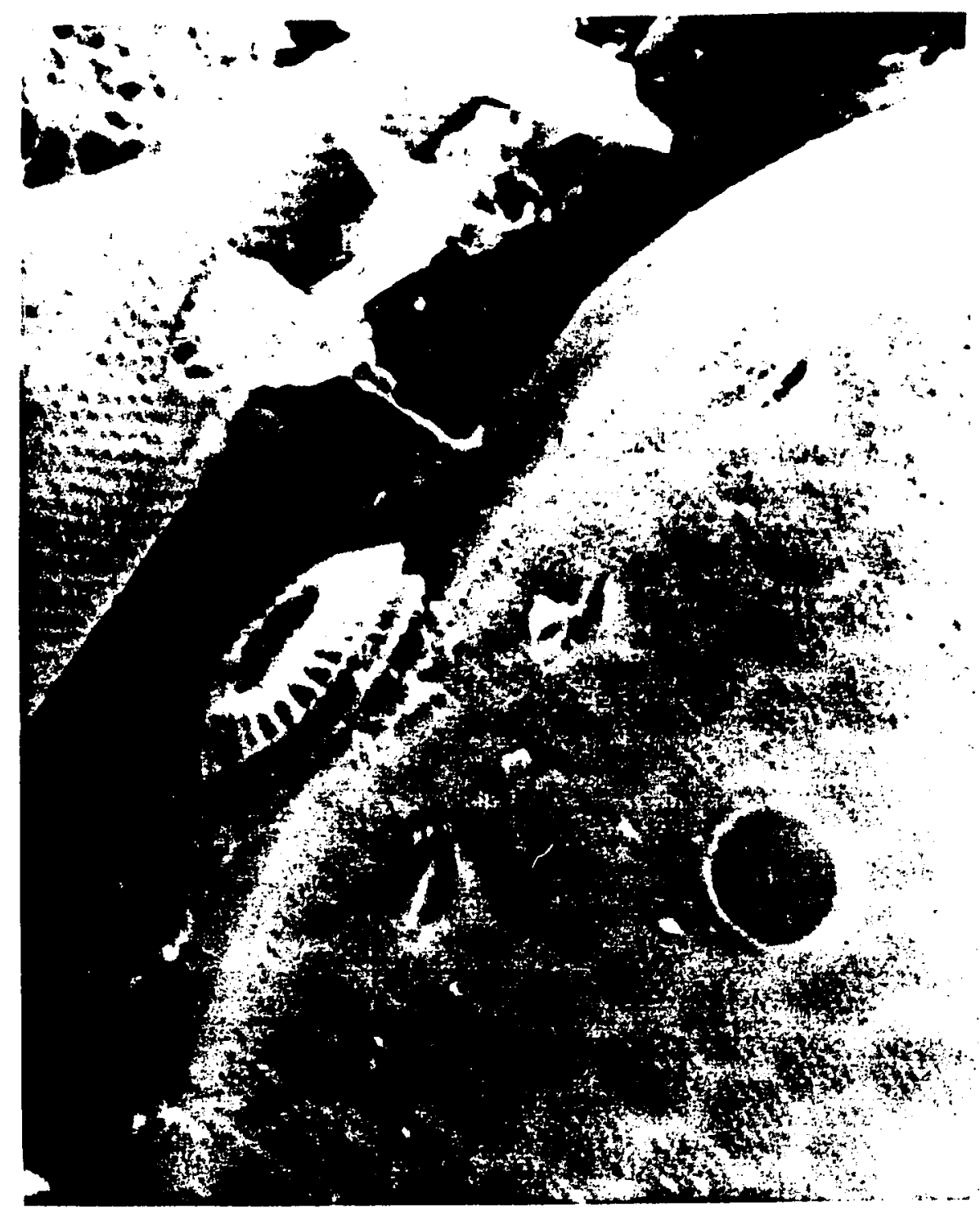
$10 \mu \mathrm{m}$ 
plant material, E. vittata is here considered a deposit feeder. The diatoms ingested were probably recently settled planktonic species, since most $\underline{E}$. vittata occur at depths too great to support diatom growth.

Thirteen specimens of Marphysa bellii were dissected for observation with a light microscope, and of these 3 were viewed under SEM. of those examined under light microscope, most had formed fecal pellets of detritus and a few diatoms. Included in the detritus were various items such as small peices of chitin and a few setae. Because of the small size of these items, it is postulated that they were ingested with the detritus. None of the specimens contained large sand grains. The SEM was used to view numerous fecal pellets. They revealed that the great majority of material in the fecal pellets was amorphous detritus. Each pellet included many broken pieces of diatoms (Figure 9), a few small centric diatoms ( 5 to $10 \mu \mathrm{m}$ ), and a few coccoliths. One contained two setae (10 and $15 \mu \mathrm{m}$ in diameter), and much detritus tightly bound by mucus (Figure 10 and 11 ). The vast majority of all the pellets consisted of amorphous detritus bound by mucus, indicative of deposit-feeding habits.

\section{Fauveliopsidae}

Fauveliopsidae is a newly-described family (see Hartman 1971) of deep-water polychaetes closely allied to flabelligerids. They may be characterized as having only a few (10 to 50 ) biramous segments, a reduced prostomium, a ventral muscular pad on the proboscis, and only a 
Figure 9. Scanning electron micrograph of gut contents of Marphysa bellii. Diatom fragments are at bottom and upper left. 


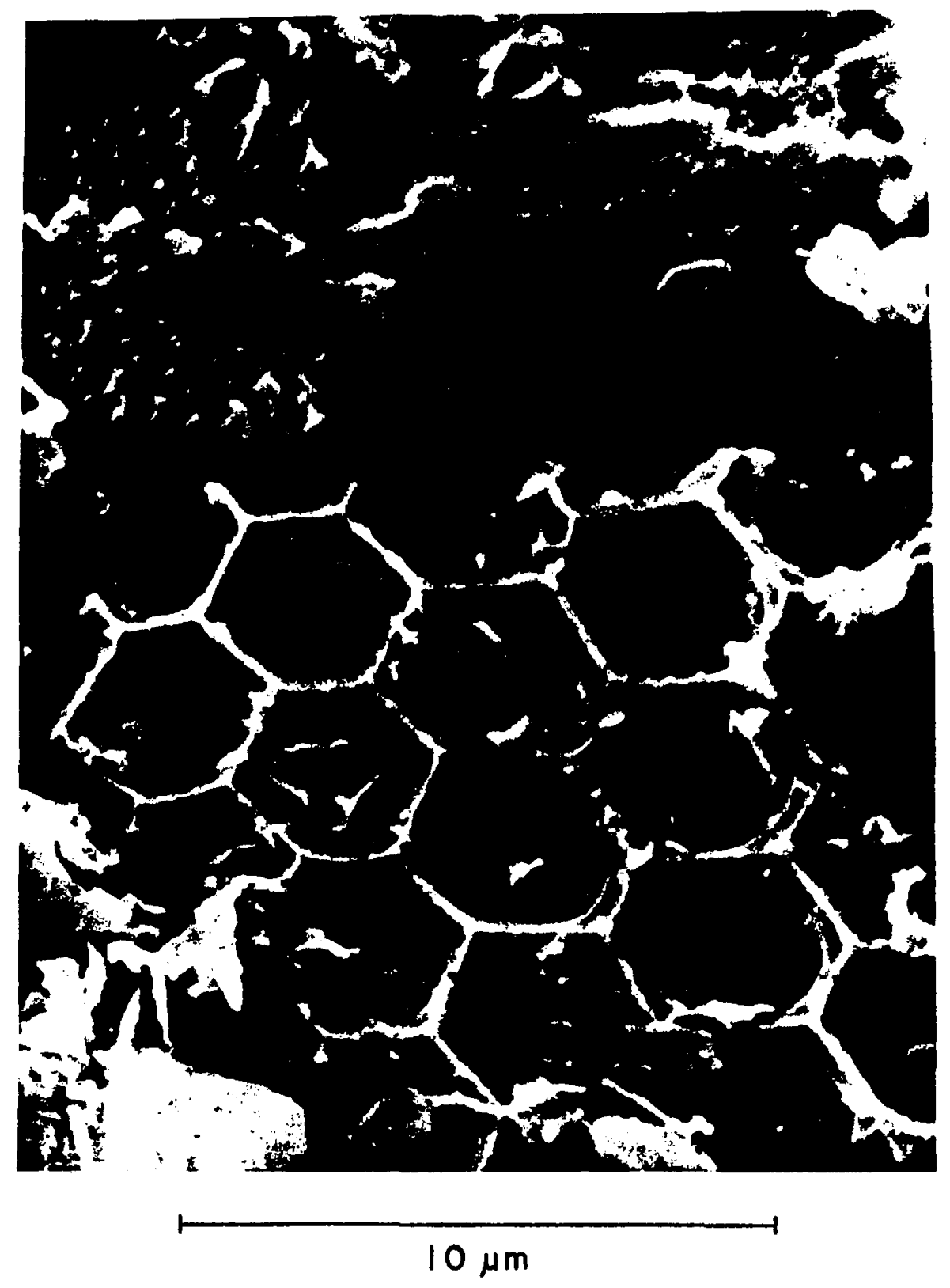


Figure 10. Scanning electron micrograph of gut contents of Marphysa bellii. Polychaete seta is at upper left. Feldspar particles are at lower right and upper center. 


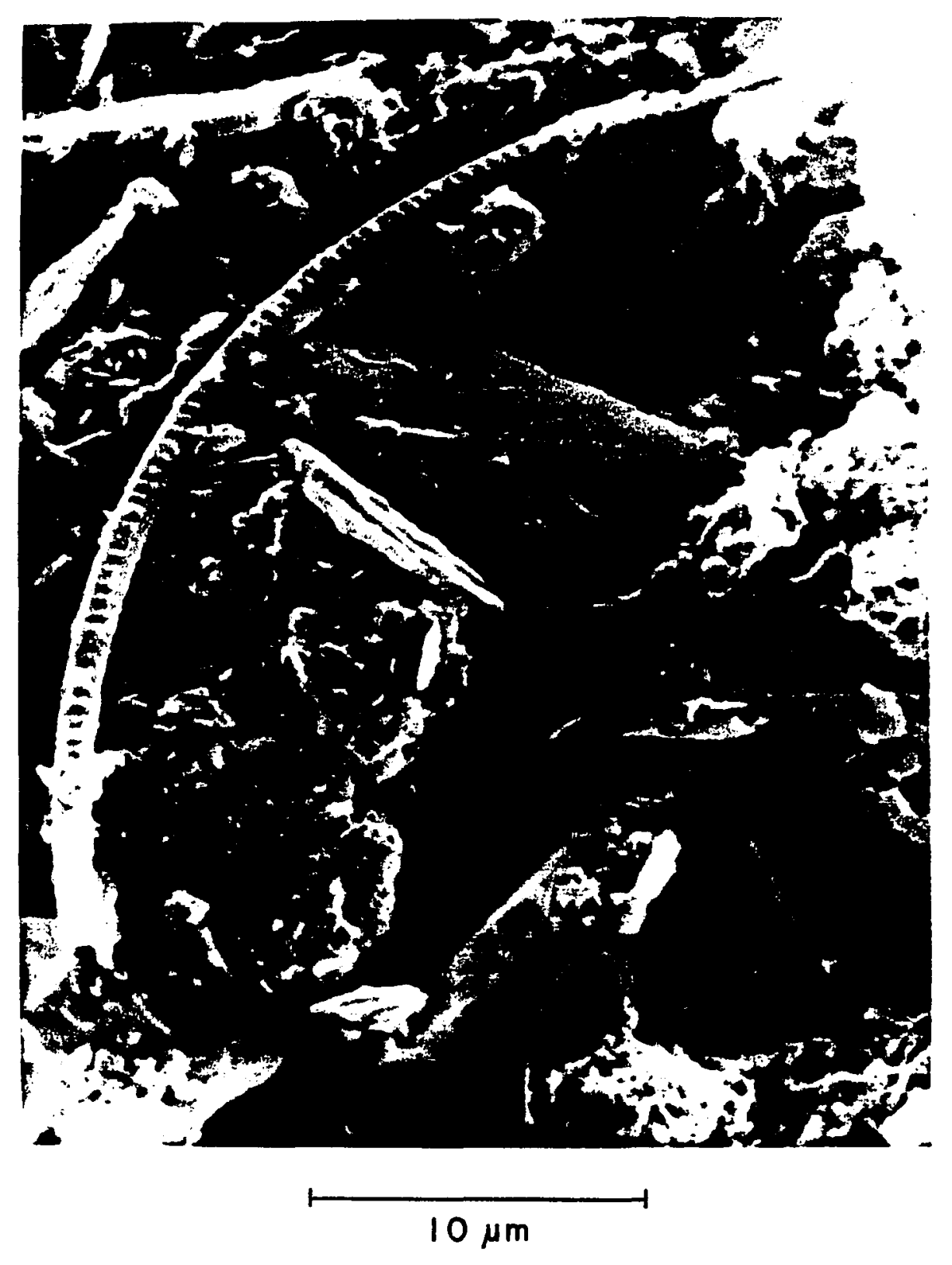


Figure 11. Scanning electron micrograph of gut contents of Marphysa bellii. Polychaete seta is at upper left. Two coccoliths are at lower right. 


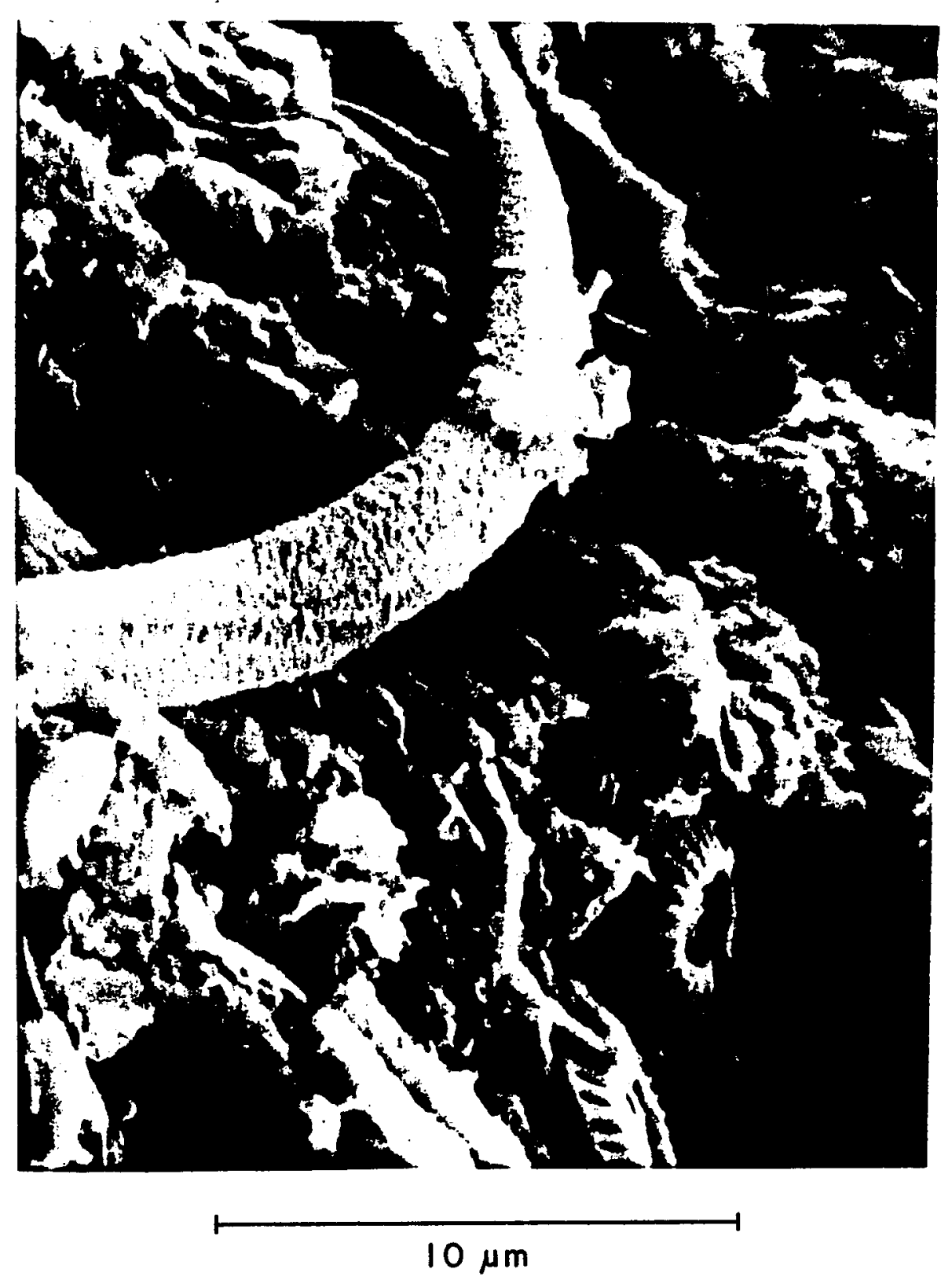


few smooth acicular setae (Fauveliopsis and Bruunilla) or no setae (Flota). Little is known of their feeding habits. Fauchald and Jumars (1979) postulated that they are subsurface deposit feeders. Only a single species, Fauveliopsis sp. A, was collected in this investigation. A11 specimens were found scattered at shelf-break and in slope depths, and all occcupied small shells of the gastropod, Mitrella amphissella. The guts were filled with very fine sediment. Since all specimens examined occupied tubes constructed within the aperture of Mitrella, and since all specimens were extremely small in comparison to the gastropod shells, Fauveliopsis is here characterized as a sessile, surface deposit feeder.

\section{Glyceridae}

Glycerids are free living, elongate polychaetes with four jaws on an eversible, muscular pharynx. They are capable of rapid burrowing, and often inhabit physically dynamic habitats such as open beach zones.

Most investigators categorize all members of the family as carnivores (Blegvad 1914, Hunt 1925, Yonge 1928, Hempelmann 1931, Southward 1957, Day 1967, Evans 1971, Pearson 1971, Ronan 1977). Some species, however, are reportedly detritivores: Glycera dibranchiata (Klawe and Dickie 1957, Sanders et al. 1962); G. capitata and $\underline{\text { G. }}$ gigantea (Hartmann-Schroder 1971); G. unicornis (Stolte 1932). Fauchald and Jumars (1979) concluded that the carnivorous habit is the 
primary feeding mode, but that some species have become detritivores. Furthermore, bathyal and abyssal species may use both modes.

In this investigation seven species of glycerids were collected:

G7ycera capitata 0 ersted, 1843

G]ycera dibranchiata Ehlers, 1868

Glycera papillosa Grube, 1857

Glycera robusta Ehlers, 1868

Glycera sp. A

Glycera sp. B

Hemipodus roseus Quatrefages, 1865

G. dibranchiata was the only glycerid collected across the shelf. It was most abundant at middle shelf depths and absent in slope habitats. It was one of few large polychaetes (i.e. longer than $50 \mathrm{~mm}$ ) which occurred at all depths on the shelf. Both $\underline{G}$. robusta and $\underline{G}$. capitata were similarly widely distributed, but in less abundance. $\underline{H}$. roseus was limited in distribution to inner and middle shelf habitats (e.g. station $\mathrm{Cl}, \mathrm{C} 2, \mathrm{C} 3, \mathrm{Gl}, \mathrm{K} 1)$. The other species, G. papillosa, Glycera sp. A, Glycera $\mathrm{sp}$. B, were never collected in abundance.

Only the four most abundant species (G. dibranchiata, G. robusta, G. capitata, and $\underline{H}$. roseus) were dissected for gut contents. In light of the characterization of Glycera dibranchiata as one of few glycerid detritivores (Klawe and Dickie 1957, Sanders et al. 1962) and its abundance in the study area, especially careful dissections of this species were made. Klawe and Dickie (1957) reported that $\underline{G}$. dibranchiata regurgitated fecal pellets rather than pass them through 
the anus; therefore, care was also taken in dissecting the foregut and midgut areas where the fecal pellets reportedly occur. In most specimens the gut was completely devoid of any material whatsoever. Several specimens contained one or two large quartz sand grains that may have been incidentally ingested during predatory feeding. One $118 \mathrm{~mm}$ specimen contained an amphipod crustacean, some polynoid polychaete setae, and several large quartz sand grains in the midgut. All specimens of the other three species dissected, G. capitata. G. robusta, and Hemipodus roseus, had empty guts except for a few large sand grains in a specimen of $\underline{H}$. roseus. All four species of glycerids analyzed from the study area are considered carnivores.

\section{Goniadidae}

Goniadids are elongate polychaetes with a muscular, eversible pharynx encircled by a series of finly-toothed jaws. Such morphology has been considered indicative of a carnivorous life style by many authors, (e.g. Southward 1957, Wolff 1973) though only scant data on feeding by goniadids are available. Fauchald and Jumars (1979) note that only three species, Glycinde armigera, $\underline{\text { G. nordmanni, and Goniada }}$ maculata, have been investigated in feeding studies. All were considered carnivores, but based on weak evidence. For instance, Blegvad (1914) dissected only nine specimens, all with empty guts, before concluding that Goniada maculata was a carnivore. Fauchald and Jumars (1979) agreed that all goniadids probably are carnivores, but indicated a need for additional data on both feeding and locomotory habits. 
Five species of goniadids were collected in this investigation:

Goniada brunnea Treadwe11, 1906

Goniada maculata 0ersted, 1843

Goniada norvegica Oersted, 1845

Goniada teres Treadwe11, 1931

Goniadella gracilis (Verri11, 1873)

Goniadella gracilis was the most abundant goniadid, and occurred predominantly in unstable sands across the shelf. Its distribution is described in detail later. Goniada maculata, G. norvegica, and $\underline{G}$. brunnea also had widespread distribution, but were less abundant. Goniada teres was limited to outer shelf and slope habitats (e.g. stations $K 4, L 4, L 5)$.

A 11 five species were dissected for gut contents, though most of the effort was spent on the more abundant species. The diminutive size of Goniadella gracilis (usually less than $10 \mathrm{~mm}$ in length) made dissections extremely tedious; however, more than 100 specimens were examined. In 211,96 of these were completely empty. Three specimens contained minute amounts of fine detritus, presumably incidentally ingested during predatory feeding or remaining from prey gut content. Three specimens contained spines and setae of other polychaetes, possibly syllid setae, sand masses tightiy bound in mucus and large quartz sand grains. Twelve specimens contained only sand. Numerous carnivores (e.g. Aphroditidae, Glyceridae) ingest large sand grains, and their presence in an otherwise empty gut may indicate predatory feeding. 


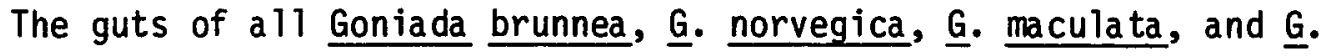

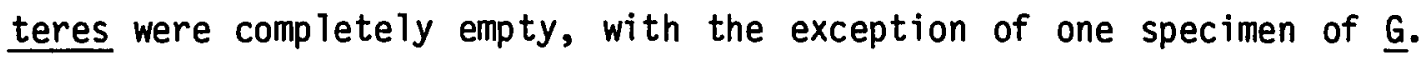
brunnea which contained a tiny amount of unidentifiable organic material in the posterior gut. It was not possible to determine whether the material was a digested organism or ingested detritus. There was no fine sand mixed in with the organic material as is sometimes the case in detritivores, but on the other hand there were no chitinized or calcified parts, which could provide conclusive evidence of animal prey, either. All species of goniadids collected in this investigation are, nevertheless, considered carnivores. Furthermore, due to the physically unstable nature of the sediments occupied by Goniadella gracilis, it is hypothesized that this particular species does not form burrows, but moves freely through the sediments in search of prey. Smaller and juvenile specimens may feed on interstitial organisms, especially in habitats of medium to coarse sand where littie silt and clay are present.

\section{Hesionidae}

Hesionids have a well-developed prostomium with eyes and elongate sensory appendages. The pharnyx is eversible, but often without jaws. Parapodia are strong, well developed for rapid locomotion, and are usually equipped with long dorsal cirri. Fauchald and Jumars (1979) noted a lack of literature on most species; however, they postulated that non-interstitial species are carnivorous. Studies by Westheide (1967) and Wolff (1973) established that interstitial species feed on 
diatoms, bacteria (by ingesting detritus), and possibly copepods and forams. Recent investigations by Shaffer (1979) and Oug (1980) provide data in support of Fauchald and Jumars' hypothesis. Shaffer found that Podarke pugettensis preys on a variety of small invertebrates, including members of at least nine families of polychaetes. The most abundant prey items, however, were harpacticoid copepods. Oug found that Ophiodromus flexuosus and Nereimyra punctata were also predaceous, feeding mostly on small crustaceans and polychaetes. Limited amounts of bottom material (i.e. algae, diatoms, detritus) was found in their fecal pellets as well, but this probably as pasively ingested during predatory feeding. Oug determined that $\underline{0}$. flexousus is a motile predator on the sediment surface. N. punctata constructs a burrow system from which it ambushes prey; however, evidence indicates that $\underline{N}$. punctata may also leave the burrows to seek prey on the sediment surface. Quantitative information on feeding in any other species of non-interstitial hesionids is completely lacking.

Three species of hesionids were collected in this investigation:

Gyptis sp. A

Hesionidae sp. A

Podarke cf. obscura Verri11, 1873

None of these species was ever collected in abundance. Gyptis sp. A and Podarke cf. obscura usually occurred in outer shelf and shelf break habitats (e.g. stations A1, A2, A3). Hesionidae sp. A was collected only on the slope (i.e. stations J1, J2, H1), and never in abundance. 
No complete specimens of any of these species were collected during the BLM Middle Atlantic Bight Study. Incomplete specimens (i.e. those lacking a posterior gut) of Gyptis sp. A were examined for gut content; all were empty. Based on the morphology and the results of Shaffer's (1979) and Oug's (1980) studies, these three hesionids ae considered carnivores.

\section{Lumbrineridae}

Lumbrinerids are elongate, cylindrical polychaetes with welldeveloped jaws, but usually with no eyes or obvious sensory prostomial appendages. The jaw apparatus consists of a pair of mandibles, four pairs of maxillae, and a pair of maxillary carriers. The first pair of maxillae are modified into pincer-like jaws which may be armed with poison glands (Fauchald, personal communication). A11 species are active burrowers that may inhabit temporary burrows (Fauchald and Jumars 1979).

Lumbrinerids are generally considered to be carnivores, though there is little direct evidence to support such an assumption. Blegvad (1914) reported several polychaetes, nemerteans, bivalves, ophiuroids, and crustaceans among prey of Lumbrineris fragilis. In 1975, Zibrowius et al. described the commensal life style of $\underline{L}$. flabellicola, a lumbrinerid that feeds on material captured by cnidarians of the genera Caryophyllia and Flabellum. Feeding in other Tumbrinerids has not been described. 
Though many authors report carnivory among all lumbrinerids (e.g. Blegvad 1914, Hunt 1925, Yonge 1928, Day 1967, Pearson 1971, Wolff 1973), studies on Lumbrineris impatiens indicate herbivorous feeding (Hemplemann 1931, Yonge 1954, Hartmann-Schroder 1971, Faucha 1d and Jumars 1979). Additionally, Sanders et al. (1962) characterized Ninoe nigripes as a selective deposit feeder. Four species studied by Banse and Hobson (1968), ㄴ. bicirrata, ㄴ. californiensis, ㄴ. cruzensis, and L. luti, all contained limited amounts of detritus and sand, indicating deposit feeding.

Eight species of lumbrinerids were collected during this investigation:

Lumbrinerides acuta (Verri11, 1879)

Lumbrineris a lbidentata (Ehlers, 1908)

Lumbrineris fragilis (Muller, 1776)

Lumbrineris impatiens (Claparede, 1868)

Lumbrineris latreilli (Audouin and Milne-Edwards, 1833)

Lumbrineris cf. tenuis (Verri11, 1873)

Ninoe brevipes (McIntosh, 1903)

Ninoe nigripes Verri11, 1873

Several of these species, including Lumbrineris fragilis, 느. latreilli, ㄴ. impatiens, Ninoe nigripes, and Lumbrinerides acuta occurred in abundance across the shelf. 느. latreilli and 느. acuta were among the most abundant of macroinvertebrate species collected in the Middle Atlantic Bight BLM study (Boesch 1979a). ㄴ. albidentata was limited to outer shelf, shelf break, and slope habitats (e.g. stations 
$F 1, F 2, H 1, H 2)$. L.. cf. tenuis, and N. brevipes were rare to moderately abundant, and occurred only in deep water habitats (e.g. stations $K 6, H 2, J 1, J 2)$. A 11 species except $\underline{L}$. cf. tenuis and $\underline{N}$. brevipes were included in gut content studies.

Lumbrinerides acuta was most abundant in unstable sand habitats (e.g. stations B4, E3, G1). The majority of specimens collected were small (5 to $15 \mathrm{~mm}$ in length), and are probably interstitial burrowers. Gut contents analysis failed to reveal a specific diet, though predation is the likely feeding-mode. Of over 100 specimens dissected, none contained an identifiable prey item. Most specimens (over 90\%) were completely empty. Two specimens contained a minute amount of fine detritus. Two other specimens contained only 1 or 2 large quartz sand grains. Several contained tightly-bound fine sand grains that appeared to have been ingested and later bound with mucus in the gut. These sand grains first were thought to be forams with agglutinated sand tests; however, closer observation ruled this out. It is possible that this species preys on soft-bodied organisms such as archiannelids or nematodes that are easily digested and have no chitinized parts detectable by dissection. The detritus found in the guts of the specimens mentioned above may have originated in prey organisms. It is hypothesized that $\underline{L}$. acuta is a predator.

Lumbrineris albidentata is a relatively large lumbrinerid (often more than $50 \mathrm{~mm}$ long). It is probably carnivorous. The guts were empty in most specimens, and only a few large sand grains were in those not empty. 
Gut analysis of Lumbrineris fragilis shorter than $20 \mathrm{~mm}$ in length revealed detritus, fine sand, amorphous organic material, empty foraminiferan tests, pieces of diatom frustules, but no live diatoms or other living material except commensal ciliates often found in the guts of the polychaetes. Specimens longer than $20 \mathrm{~mm}$ had gut contents indicating carnivorous habits. The majority of dissected larger specimens were completely empty. Although no whole prey organisms were found, spines and setae of polychaetes were present in several specimens. others contained only a few large sand grains. It is hypothesized, therefore, that juvenile specimens are facultative detritivores and large specimens exclusively carnivores.

Lumbrineris impatiens, like juvenile specimens of $\underline{\text { L. }}$ fragilis, is a deposit feeder. Fauchald and Jumars (1979) and others indicated that this species should be a herbivore, however, specimens collected in the Middle Atlantic Bight never contained plant material or any live diatoms. Gut contents primarily consisted of amorphous organic material and fine sand. A few pieces of diatom frustules were also found in one specimen. As discussed above (see Eunicidae), most specimens of $\underline{\text { }}$. impatiens occur at depths too great to support diatom growth. Diatoms present in the guts of these species probably settled from the water column, and therefore, would be considered detrital in origin.

The gut content of Lumbrineris latreilli gut contents analyses indicate a deposit-feeding habit. None of the specimens examined had guts entirely filled with detritus; however, all specimens contained some. Included in the items ingested were particles of fine sand (100 
to $130 \mu \mathrm{m}$ ), pieces of diatoms, and 1 to 2 medium sand grains (250 to $280 \mu \mathrm{m})$. A specimen collected at the shelf break (station A4) contained several empty tests of the foraminiferan genus, Globigerina, which constitute much of the sand size particles in sediments of this location.

Guts of the specimens of Ninoe nigripes were filled with detritus; as suggested by Sanders et al. (1962), this species must be a detritivore. Both juvenile (less than $25 \mathrm{~mm}$ in length) and adult specimens contained large amounts of detritus, much fine sand and silt, and the amorphous material characteristic of detritus-feeding forms. Among the material which was apparently ingested incidentally with the detritus was a dinoflagellate, both large and small entire centric and pennate diatoms, and several black mineral grains. The small diatoms (less than $0.5 \mathrm{~mm}$ ) were apparently live when ingested. The large diatoms, mostly centric, were primarily broken frustules; however, one centric diatom, found in a $55 \mathrm{~mm}$ Ninoe, was apparently live when ingested (i.e. the striae were filled with mucus and/or protoplasm).

\section{Ma 1danidae}

The feeding of maldanids is well documented in the literature (e.g. Mangum 1964, Rhoads 1967, 1974, Kudenov 1977, 1978). There is ample evidence to indicate that most species investigated feed while orientated prostomium-down in their tubes. In so doing, they are characterized as subsurface deposit feeders in the literature. 
However, one species, Praxillura longissima, is here considered a surface deposit feeder. $\underline{P}$. longissma is most abundant in outer shelf and slope habitats (e.g. stations $H 1, H 2$, I4). It apparently feeds prostomium-up on material surrounding its tube. The evidence in support of this hypothesis is based on bottom photographs (Boesch, personal communication) and observations on preserved specimens. Anterior ends of Praxillura were collected in the Smith-McIntyre grabs and Anchor dredges, indicating that the sampler failed to penetrate the entire length of the species' tube. No posterior ends were collected. Additionally, the morphology of Praxillura seems adaptive to surface feeding. Praxillura possesses an enormous mouth, different in shape from that of most shallow-water maldanids. Such a structure could be used to ingest surface material within reach of the tube opening. Its tube is thin-walled, but firm and flexible, with sand agglutinated to a mucus lining. The guts were filled with coarse sand and little detritus. Most large particles ingested were 300 to $1000 \mu \mathrm{m}$ diameter quartz sand.

All other species collected in this investigation are assumed to be subsurface deposit feeders. Those species include:

Asychis carolinae Day, 1973

Asychis biceps (Sars, 1861)

Axiothella sp. A

Clymenel la torquata (Leidy, 1855)

Clymenella sp. A

Clymenura $\mathrm{sp}$. A 
Euclymene zonalis (Verrill, 1874)

Maldane sp. A

Praxillella sp. A

Praxillella gracilis (Sars, 1861)

Rhodine loveni Ma $7 \mathrm{mgren}, 1865$

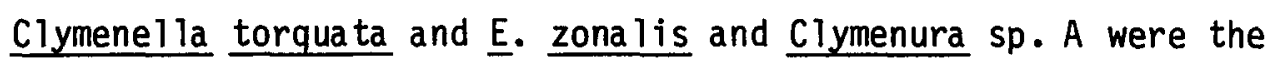
three most abundant maldanids collected. All occurred across the shelf, but most densely populated quiescent areas of finer sediments (e.g. stations A2, D4, F4). Asychis carolinae also was abundant, but limited to middle shelf to shelf break habitats (e.g. stations F2, G5, I3, K5). The distributions of these species are discussed later in this study. None of the other species occurred in appreciable numbers.

\section{Nephtyidae}

Nephtyids are active, burrowing polychaetes which feed with a large eversible pharynx equipped with a single pair of jaws. Most investigators (e.g. Blegvad 1914, Hunt 1925, Yonge 1928, Southward 1957, Day 1967, Ronan 1977, Rao and Sarma 1978) are in agreement that nephtyids are carnivorous. Their prey probably reflect the composition of the invertebrate fauna they encounter, including molluscs, crustaceans, and other annelids. There is evidence that populations of Nephtys incisa which inhabit Long Island Sound and Buzzard's Bay may be deposit-feeders (Sanders 1956, 1960). Fauchald and Jumars (1979) hypothesize that $\underline{\mathrm{N}}$. incisa populations in these areas, though similar in 
morphology to $\underline{N}$. incisa in Europe, are actually divergent groups. The two populations may actualiy represent separate species, though Fauchald and Jumars did not indicate that such was suspected.

Seven species were collected during this investigation:

Aglaophamus circinata (Verri11, 1874)

Nephtys bucera Ehters, 1868

Nephtys caeca (Fabridius, 1780)

Nephtys incisa Malmgren, 1865

Nephtys picta Ehlers, 1868

Nephtys squamosa Ehters, 1887

Nephtys sp. A

Both $\underline{A}$. circinata and $\underline{N}$. bucera occurred in abundance across the shelf. The most abundant nephtyids, however, were the indistinguishable juveniles of the two species. Because juvenile nephtyids were among the most numerically dominant polychaetes collected at many sites, they were included as a separate group in the gut content analysis. N. incisa and $\underline{N}$. picta were the only other taxa dissected. All other species were considered motile carnivores.

Fifty specimens of Aglaophamus circinata were examined for gut content. Only six contained any ingested material at all. The material included large quartz sand grains (400 to $500 \mu \mathrm{m}$ diameter), tightly-bound mucus masses of sand similar to that found in Lumbrinerides acuta, and remains of lumbrinerid and spionid polychaetes. These results indicate carnivorous habits. 
Dissections of Nephtys bucera led to the same conclusion. Specimens contained polychaete setae and peracaridan crustaceans. Only one specimen contained the large sand grains (200 to $500 \mu \mathrm{m}$ diameter) seen in Aglaophamus circinata.

Juvenile nephtyids (mostly 2.5 to $5.0 \mathrm{~mm}$ in length) were mostly empty. Of forty specimens dissected, only four contained ingested materia1. One contained a few large sand grains and a minute amount of detritus. Three specimens had ingested unidentifiable prey organisms. A 11 three contained detritus and an abundance of capillary setae, indicating carnivorous feeding.

Al1 specimens of Nephtys incisa and $\underline{N}$. picta were empty. They were included with the other nephtyids as carnivores.

\section{Nereidae}

Nereids are probably the best investigated of all polychaetes. They are often used as the "typical" polychaete, probably because they have numerous sensory appendages on the prostomium, four eyes, welldeveloped parapodia, and are readily accessible to biological supply companies. Their muscular pharynx is eversible, and is equipped with a pair of jaws usually supplemented by auxilliary paragnaths.

A great deal of information is available of feeding in nereids, probably because of their use in laboratory experiments. A complete list of literature on nereid feeding is provided by Fauchald and Jumars (1979). The most comprehensive of the studies was conducted along the German Coast by Goerke $(1966,1971)$. Using both field and laboratory 
data, Goerke concluded that Nereis pelagica, ‥ virens, and $\underline{N}$.

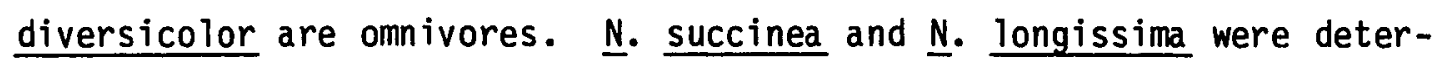
mined to be "mainly deposit and detritus feeders," and ‥ fucata (a commensa 1 with pagurids) to be primarily carnivorous. In general, the literature presented by Fauchald and Jumars characterized the majority of nereids as free-living omnivores that may occupy temporary tubes of sand and mud.

Since Fauchald and Jumars (1979) completed their investigation, additional information has been published. Tsuchiya and Kurihara (1979) investigated detritus feeding in Neanthes japonica, and provided data on both the components of detritus and on the importance of each component to the nutrition of the species. Jorgensen (1979, 1980) measured the uptake of amino acids in Nereis virens to provide insight into its role in nutrition of invertebrates. Woodin (1977) described "gardening" by $\underline{N}$. vexillosa and Platynereis bicanaliculata, a method by which these species attach drift algae to their tubes for later consumption. In a North Carolina estuary, Cammen et al. (1978) measured microbial carbon assimilation in Nereis succinea, concluding that nutritional requirements of the species exceeded the energy provided by the digestion of microbes. Cammen's information of the previously untested hypothesis that all nutrition of detritivores comes solely from microbes, suggests that alternate feeding methods or direct uptake or dissolved organic matter may be more important than previously believed.

Four species of nereids were collected during this investigation: 
Ceratocepha le loveni Malmgren, 1867

Neanthes succinea (Frey and Leuckart, 1847)

Nereis grayi Pettibone, 1956

Nereis zonata Malmgren, 1867

Only N. grayi occurred in abundance across the shelf. $\underline{N}$. zonata was most abundant in mid-shelf depths, and $\underline{C}$. loveni was limited in distribution to shelf break and slope habitats. N. succinea, typically an estuarine species, occurred mostly in inner and middle shelf habitats. Members of all species except $\underline{N}$. succinea were dissected for gut contents.

Nereis grayi is a deposit feeder. Guts of dissected specimens contained an abundance of detritus including forams, both whole and broken diatoms, fine and medium quartz sand grains ( 80 to $300 \mu \mathrm{m}$ ), ingested fecal pellets, and numerous small unidentifiable items.

Nereis zonata also ingested detritus, and, therefore, is characterized as a deposit feeder. It should be noted, however, that none of the specimens examined contained filled guts as did those of N. grayi. Gut contents included smal1 amounts of detritus, both medium and sma 11 quartz and feldspar sand grains (100 to $300 \mu \mathrm{m})$, dinoflagellate tests, foram tests, and several unidentifiable items. One specimen included a minute piece of a terrestial plant.

Ceratocephale loveni also is a deposit feeder. Guts of this species were filled with detritus and fine sand. Identifiable items included diatom test (broken and entire), forams, and sma 11 pieces of 
echinoderm tests. All of these items were probably incidentally ingested with the fine sand.

Gut contents of two specimens of $\underline{C}$. loveni were also examined under SEM. Most of the ingested material was sediment. There was little indication that this species is particularly selective in sediment ingested, as the particles ranged from coarse silt (65 $\mu \mathrm{m})$ to medium clay (1 to $2 \mu \mathrm{m})$. No sand particles were observed; however, sand contributes only about $6 \%$ of the sediment at slope depths (e.g. station J2) where these two specimens were collected (Boesch 1979b).

Onuphidae

Onuphids are elongate polychaetes with numerous sensory appendages on the prostomium. All species are tubicolous, though two of the species collected in this investigation (Nothria conchylega and Hyalinoecia artifex) move about freely dragging their tubes along.

Feeding of onuphids has been intensively investigated, though no clear pattern has emerged for the family. They have been characterized as carnivorous by Schafer (1962) and Hartmann-Schroder (1971). Numerous species, including Diopatra ornata, ‥ neapolitana, ‥ cuprea, ㅁ. monroi, and Epidiopatra gilchristi are, at least in part, herbivorous (Hempelmann 1931, Yonge 1954, Day 1967, Mangum and Cox 1971, Myers 1972). Hyalinoecia spp. has been attracted to carrion (Dayton and Hessler 1972). Fauchald and Jumars (1979) hypothesized that onuphids are omnivorous scavengers, and specialize as the availability of food varies in different depths and habitats. Furthermore, deep-water 
species of Nothria, which are thought to be sessile, may be truly omnivorous due to the scarcity and inconstancy of food supply in the deep sea.

Eleven species of onuphids were collected during this investigation:

Diopatra cuprea (Bosc, 1802)

Diopatra sp. A

Hyalinoecia artifex Verrill, 1880

Nothria conchylega (Sars, 1835)

Onuphis atlanticum (Hartman, 1965)

Onuphis eremi ta Audouin and Mi Ine-Edwards, 1833

Onuphis nebulosa Moore, 1911

Onuphis opalina (Verri11, 1873)

Onuphis pallidula (Hartman, 1965)

Onuphis declivorum Faucha ld, 1982

Rhamphobrachium sp. A

The two most abundant onuphids were $\underline{N}$. conchylega and $\underline{0}$. pallidula. Both numerically dominated the macroinvertebrate fauna of certain outer shelf and shelf break habitats, but were uncommon in mid-shelf and slope habitats. Onuphis atlanticum was most abundant in shelf break and slope habitats (e.g. stations A4, H1, J1). Only two other species occurred in abundance: $\underline{H}$. artifex, limited to slope depths; and $\underline{D}$. cuprea, an inner shelf and estuarine species. Only ‥ conchylega, $\underline{0}$. atlanticum, $\underline{0}$. pallidula, and $\underline{H}$. artifex were included in the analysis. No complete specimens of the other species were available. 
For Unuphis pallidula, dissections revealed that most specimens ingested sma 11 amounts of detritus. Guts were never completely filled. In addition to unidentifiable detritus, guts of most specimens contained numerous diatoms. Several specimens contained what appeared to be tube fragments as well as the diatoms. Three tubes of $\underline{0}$. pallidula were examined with stereo and compound microscopes to determine whether similar diatoms collected in the tubes. Few diatoms were observed in the tubes. The ingested diatoms were apparently planktonic in origin, and ingested with other detrital material.

Onuphis pallidula fecal pellets were also examined under SEM. The pellets were tightly bound with mucus, and covered with bacteria (Figure 12). A few diatoms (Figure 13), only one of them pennate (20 $\mu \mathrm{m}$ in length), were observed. Most diatoms were either dead when ingested or diatom fragments. There were also abundant fine silt and clay particles ( 2 to $10 \mu \mathrm{m}$ in diameter). $\underline{0}$. pallidula ingests sediment, though there is no indication of the origin of the material (i.e. tube, sediment surface, subsurface).

Onuphis atlanticum similarly ingested numerous diatoms, but, unlike $\underline{0}$. pallidula, also contained an abundance of fine sand and detritus which was formed into fecal pellets. In addition, whole and broken forams were observed.

Ingested material in specimens of Nothria conchylega, like $\underline{0}$. atlanticum, was formed into fecal pellets in the posterior gut. One specimen contained numerous diatoms; however, guts of most specimens were filled with unidentifiable detritus and only a few diatoms and 
Figure 12. Scanning electron micrograph of bacteria among the gut contents of Onuphis palijdula. 


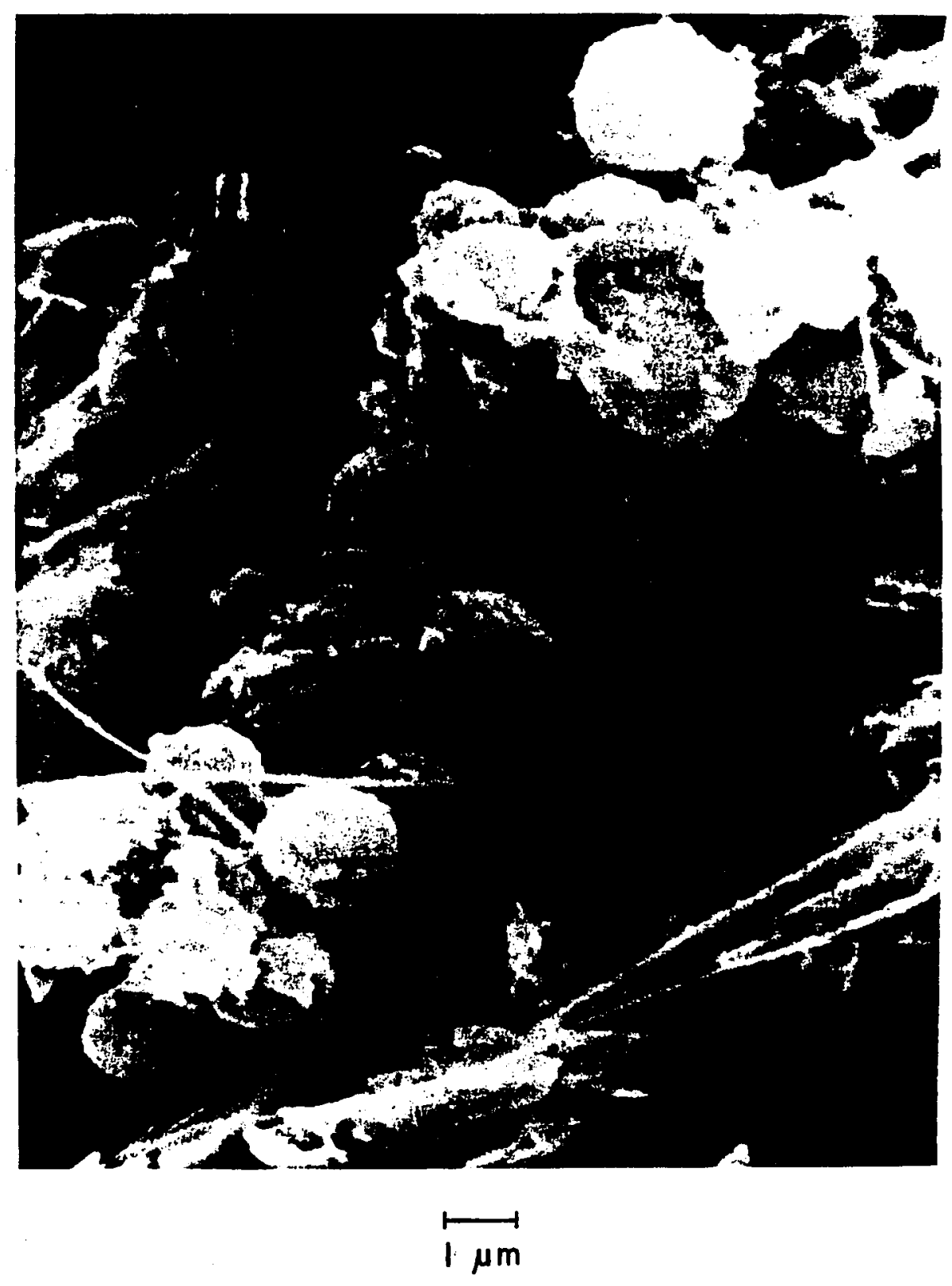


Figure 13. Scanning electron micrograph of gut contents of Onuphis pallidula. Diatom at center is Nitzchia. 


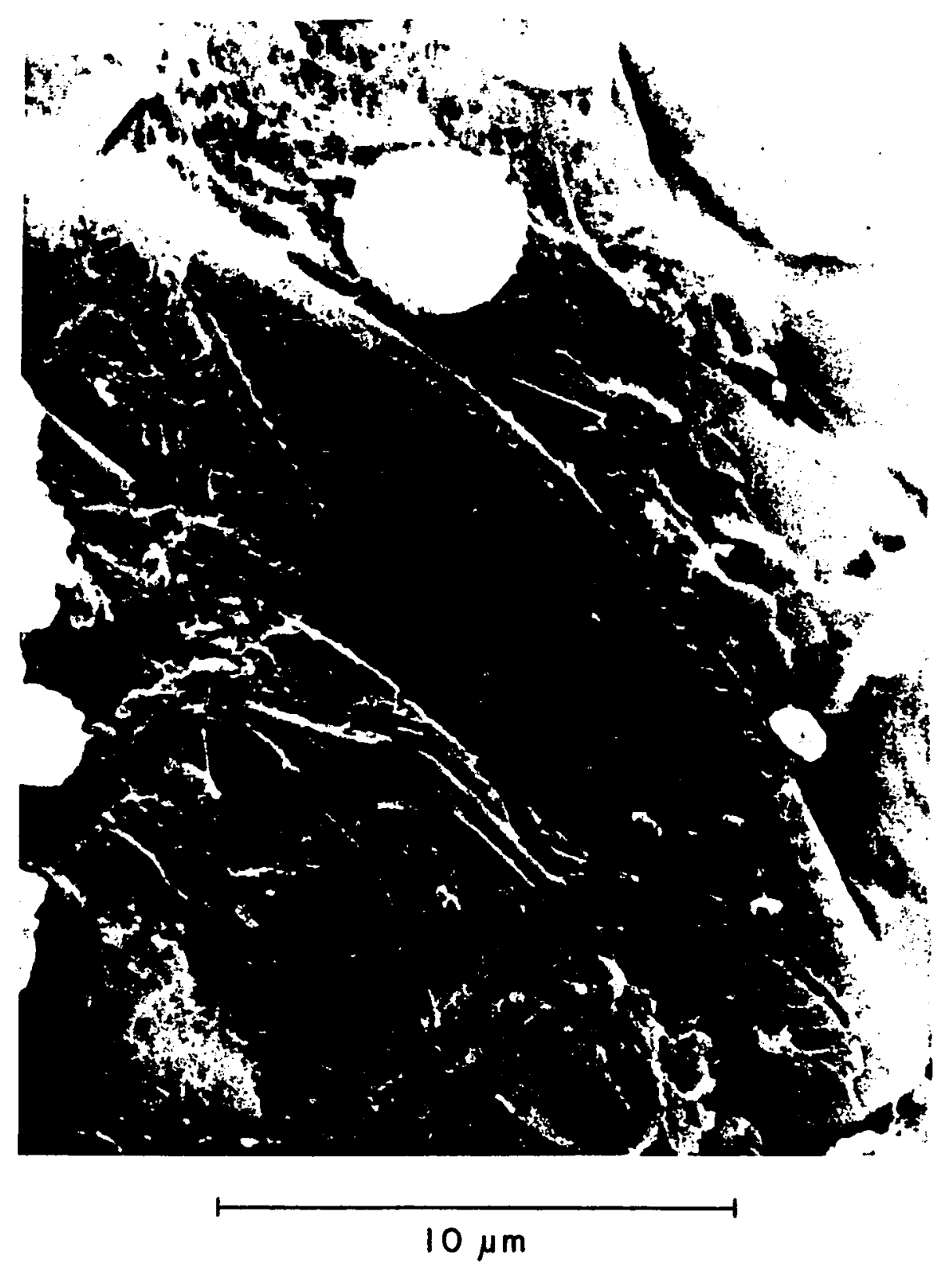


forams. N. conchylega, Onuphis pallidula and $\underline{0}$. atlanticum are here considered selective deposit feeders.

Hyalinoecia artifex is a large onuphid that inhabits a quill-like tube that is carried around with the worm. Bottom photographs taken during the Middle Atlantic Bight (BLM) investigation (Boesch 1979a) showed that $\underline{H}$. artifex is a very motile species, capable of dominating the sediment surface habitat. Gut contents analysis confirmed that it may do just that. Guts contained numerous peracaridan crustaceans and echinoid spines. The peracaridans were apparently ingested while with their tubes, indicating voracious predatory feeding. Though they may actually be omnivorous scavengers over their distribution range, specimens dissected in this investigation are predatory. Almost every specimen dissected contained some item, usually peracaridans.

\section{Paraonidae}

Paraonids are small, elongate polychaetes with an eversible, unarmed pharynx. All species are generally considered to be deposit feeders (e.g. Day 1967, Pearson 1971, Rasmussen 1973). Noteworthy exceptions to this generalization include reports of selective feeding on pennate diatoms by Paraonis fulgens in Europe (Roder 1971, Risk and Tunnicliffe 1978), and observations by Fauchald and Jumars (1979) on selective ingestion of foraminifera by paraonids in the deep sea.

Fourteen species of paraonids were collected during this investigation:

Aedicira sp. A 
Aricidea catherinae Laubier, 1967

Aricidea cerrutii Laubier, 1966

Aricidea quadrilobata Webster and Benedict, 1887

Aricidea simplex (Day, 1963)

Aricidea suecica Eliason, 1920

Aricidea wassi Pettibone, 1965

Cirrophorus branchiatus Ehlers, 1908

Tauberia gracilis (Tauber, 1879)

Paradoneis lyra (Southern, 1914)

Paraonis fulgens (Levinsen, 1883)

Paraonis pygoenigmatica Jones, 1968

Paraonis sp. A

Paraonis sp. B

A. catherinae, A. cerrutii, ‥ Iyriformis, $\underline{\text {. }}$ lyra, and L. gracilis were all abundant across the shelf. A. catherinae and $\underline{P}$. lyra were most abundant, however, in shelf-break habitats (e.g. stations A4, F3, F4), where $\underline{A}$. simplex was similarly among the most numerically dominant species. A. wassi was most abundant in inner and middle shelf habitats (e.g. stations D1, D2, G2, L1, L3), but occurred to the shelf break. None of the other species occurred in abundance. Only a few specimens of $\underline{P}$. fulgens were collected, all on the inner shelf.

Specimens of the seven species discussed above (excluding $\underline{P}$. fulgens) were dissected for gut content. All contained only detritus, fine sand ( 70 to 150 um), much silt and clay, and a few small diatoms, characteristic of material ingested by deposit feeders. None contained 
an abundance of diatoms such as those reportedly ingested by Paraonis fulgens. A11 of these species of paraonids, therefore, are classified as surface deposit feeders.

\section{Phyl lodocidae}

Phyllodocids are free-living polychaetes with well-developed anterior sensory structures including eyes, antennae, and tentacular cirri in most species. The pharynx is muscular and eversible, but without jaws. Most species are hunting carnivores (e.g. Newell 1970, Evans 1971, Pearson 1971, Wolff 1973, Emson 1977). A report by Sanders et a 1. (1962) that Eteone heteropoda ingests sediment was later complicated by observations of carnivory and cannibalism in the same species

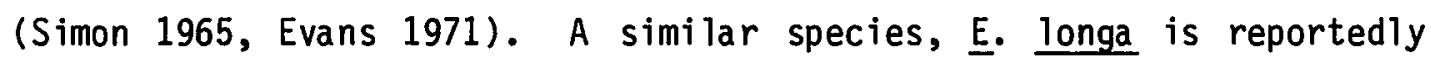
carnivorous (Retiere 1967). Fauchald and Jumars (1979) hypothesized that all phyllodocids are hunting predators, and attributed the observations by Sanders et a 1 . (1962) to be evidence of an alternate feeding method used by populations of Eteone heteropoda in Long Is land Sound.

Eighteen species of phyllodocids were collected during this investigation:

Anaitides arenae (Webster, 1880)

Anaitides longipes (Kinberg, 1866)

Anaitides mucosa (0ersted, 1843)

Anaitides sp. A

Eteone heteropoda Hartman, 1951

Eteone lactea Claparede, 1868 
Eteone sp. A

Eteone sp. B

Eulalia bilineata (Johnston, 1840)

Eulalia viridis (Linnaeus, 1767)

Eulalia sp. A

Eumida sanguinea (Oersted, 1843)

Eumida fusigera (Ma Imgren, 1865)

Hesionura sp. A

Lugia sp. A

Notophyllum foliosum (Sars, 1835)

Paranaitis kosteriensis (Ma Imgren, 1867)

Paranaitis speciosa (Webster, 1880)

Only $\underline{A}$. mucosa and $\underline{E}$. bilineata were widely distributed. They were present across the shelf, but most abundant in the middle and outer shelf. All other species occurred only rarely or in low abundance. Oniy A. mucosa and Eteone sp. A were dissected for gut contents analyses during this study. All specimens dissected were completely empty. All phyllodocids are here considered hunting carnivores.

\section{Sphaerodoridae}

Sphaerodorids are one of the least investigated families of polychaetes. Most species are minute, possibly interstitial where they occur in sandy habitats, and armed with a muscular, eversible pharynx. Though no quantitative studies of their feeding habits have been conducted, Fauchald and Jumars (1979) hypothesize that all species are 
free-living deposit-feeders which browse the sediment surface. Schafer (1962) earlier postulated the same for Sphaerodoridium claparedij.

Though sphaerodorids occurred only rarely in the study area, they have been included in this investigation due to the scarcity of information about their habits. Only four species were collected:

Sphaerodoridium claparedi i (Greeff, 1866)

Sphaerodoropsis corrugata (Hartman, 1965)

Sphaerodoropsis minuta (Webster and Benedict, 1887)

Sphaerodoridae sp. A

S. claparedii was the only species examined for gut content. Dissections were conducted by piercing the gut of whole mount specimens, allowing the ingested material to spill into the mounting medium. Since the body wall is transparent in such small species, gut material is readily apparent when present. Only 4 of 24 specimens available contained any material whatsoever. Each contained only small amounts of detritus, never enough to fill the gut. Ingested material included a sma 11 centroid diatom, fine quartz sand (60 to $80 \mu \mathrm{m}$ ), silt and clay, and some amorphous organic matter. The information is inconclusive, and neither confirms nor refutes Fauchald's and Jumars' (1979) hypothesis of surface detritus feeding. For the purposes of this study, a 11 species are considered detritivores.

\section{Spionidae}

Feeding by spionids has been extensively investigated. Fauchald and Jumars (1979) provide an excellent summary of the available liter- 
ature. They postulate, based on the literature and personal observations, that spionids are discretely motile surface deposit feeders that are capable of highly discriminatory selection of particles. They suggest that suspension feeding, as observed in species of Polydora (Linke 1939, Korriga 1951, Dorsett 1961), may supplement surface deposit feeding. Recent investigations by Taghon et a1. (1980) confirm the hypothesis, and indicate that suspension feeding by Pseudopolydora kempi japonica, Boccardia proboscidea, and Pygospio elegans occurs in response to increased water velocity, maximizing suspension feeding during the greatest flux of suspended materials. Similar observations have been made on United States east coast spionids by Dauer et al. (1981). Levin (1980) observed that Pseudopolydora paucibranchiata and Streblospio benedicti both periodically suspension feed. Additionally, she noted that Pseudopolydora aggressively defends it territory for acquisition of food and tube-building materials, a behavior previously observed only in nereid polychaetes (Roe 1975).

For the purposes of this investigation, spionids are classified both as surface deposit feeders and suspension feeders. Half of the specimens of each species are entered in the analyses below as suspension feeders and half as surface deposit feeders.

\section{Syllidae}

The morphology of syllids varies considerably between genera. Most species are considered non-tubicolous (Fauchald and Jumars 1979); they feed with the aid of a muscular, eversible pharynx connected to a 
cylindrical organ presumably used for sucking, called the proventriculus. Most species also possess a sharp tooth or series of teeth on the pharynx.

There is considerable variation in the feeding of syllids, as described in Fauchald and Jumars (1979): Autolytinae feed primarily on hydroids (Okada 1928, Hamond 1969, Hughes 1975); species of Sphaerosyllis eat diatoms and detritus (Jones 1961, Hughes 1975, Schafer 1962); Exogone gemmifera feeds on fish larvae (Rasmussen 1973); Streptosyliis websteri eats diatoms (Hartmann-Schroder 1971, Wolff 1973). In addition, Fauchald and Jumars postulate that all Exogoninae are highly selective deposit feeders that may periodically function as carnivores or carrion-feeders.

Twenty species of syllids were collected during this investigation:

Autolytus a lexandri Ma Imgren, 1867

Brania wellfleetensis Pettibone, 1956

Eusyl1is lamelligera Marion and Bobretsky, 1875

Eusyli is sp. A

Exogone dispar (Webster, 1879)

Exogone hebes (Webster and Benedict, 1884)

Exogone naidina Oersted, 1845

Exogone verugera (Claparede, 1868)

Exogone $\mathrm{sp} . \mathrm{A}$

Odontosyllis longiseta Day, 1973

Parapionosyllis longicirrata (Webster and Benedict, 1884) 
Pionosyllis sp. A

Proceraea sp. A

Sphaerosyllis erinaceus Claparede, 1863

Streptosyllis arenae Webster and Benedict, 1884

Streptosyllis varians Webster and Benedict, 1887

Streptosyllis websteri Southern, 1914

Syllides convoluta Webster and Benedict, 1884

Typosyllis hyalina (Grube, 1863)

Typosyllis tegulum Hartman and Faucha1d, 1971

Exogone hebes occurred across the shelf. E. verugera was also abundant across the shelf, but was not as common in shallow habitats (e.g. stations C1, C2, D3). Parapionosyllis longicirrata, Streptosyllis arenae and Sphaerosyllis erinaceus were moderately abundant from the inner shelf to the shelf break (e.g. stations B4, E1, E3, F4). Typosyllis tegulum was widely distributed on the shelf, but was most abundant on the outer shelf and shelf break habitats (e.g. stations E2, E4, F1). None of the other species were collected in abundance.

Exogone verugera, E. hebes, Sphaerosyllis erinaceus, and Typosyllis tegulum were dissected for gut contents analyses. E. verugera contained hundreds of fine quartz grains (approximately 3-12 um in diameter), and very small amounts of amorphous detritus in the middle and posterior gut. No diatoms, forams, or pieces of debris observed in guts of species that ingest sediment (e.g. Ninoe nigripes) were seen in any of the 36 specimens examined. Twenty-three of the specimens were completely empty. E. hebes apparently feeds on the same 
material as E. verugera, though only three of 57 specimens dissected contained any material whatsoever in their guts. Gut analyses revealed the identical contents observed in E. verugera: hundreds of fine quartz grains and sma 11 amounts of fine detritus. No diatoms or forams were seen. It should be noted that in both species the ingested material only filled small portions of the gut. No specimens had filled guts, and none contained material in the anterior gut.

The hypothesis by Fauchald and Jumars (1979) that Exogone spp. are selective deposit feeders is not at all supported by these data. Rather, this information may indicate feeding on hydroids, Anthozoa, or other animal prey, assuming the fine sediment was previously ingested by the prey organisms.

Sphaerosyllis erinaceus also contained only small amounts of very fine detritus, but differed from Exogone spp. in lacking the abundance of fine sediments seen in the species discussed above. The fine detritus was limited to the posterior gut, and represented only sma 11 amounts of material (i.e. the gut was nearly empty). Most specimens (19 of 23) were completely empty. These observations do not lead to any conclusions. Perhaps, $\underline{S}$. erinaceus sucks the contents from prey organisms, leaving little material in the gut to be observed following digestion.

Specimens of Typosyllis tegulum contained various materials in their guts. One specimen had ingested a mass of sand and detritus containing coarse and fine sand, forams, and remains of two dinoflagellates. Another contained some detritus and a piece of chitin, 
possibly indicating predatory feeding. Other specimens contained only fine detritus and fine sand. Many ( 8 of 13) were completely empty. These data do not support the postulate by Fauchald and Jumars (1979) that all Syllinae are carnivores on colonial invertebrates. Rather, I. tegulum appears to be a facultative carnivore, capable of both carnivory and selective deposit feeding. Its occurrence on the outer shelf and slope, where colonial hydroids are uncommon, may have forced it to function as an omnivore, as these da ta suggest.

\section{Broad Scale Patterns}

The spatial patterns here defined as "broad scale" referred to distribution on a scale of tens of thousands of meters. Habitat zones of the Middle Atlantic Bight were divided into 5 habitat groups for analyses of broad scale patterns in polychaete feeding biology: inner shelf; middle shelf; outer shelf; shelf break; and slope. The zone divisions were based primarily on relative depth, and to a lesser degree, on general sediment characteristics.

Boesch (1979a) had shown that macrofaunal assemblages in habitats within these zones could be distinguished by numerical classification (cluster analysis). Before analyses of polychaete feeding biology began for this study cluster analysis was conducted on polychaete abundance and distribution data. This was expected to demonstrate that many of the same habitats distinguished by Boesch could be distinguished using polychaete data alone, and would give credence to feeding biology paterns should the same habitats be distinguished by the 
feeding biology classification scheme. All polychaete species were included in the cluster analysis, as were all BLM stations and all 8 quarterly cruises (Table 2). The resultant cluster is shown in Figure 14. Site groups are indicated in Table 4. The cluster analysis indicates the distinction of middle slope polychaetes from all other assemblages. This is probably due to the low abundance of polychaetes on the middle slope. Also clearly distinguished are the shelf breakupper slope, dynamic inner and middle shelf, and intermediate depth assemblages. Most importantly, the assemblages of specific habitats are distinct within the cluster. This illustrates the importance of mesoscale features in the Middle Atlantic Bight, and demonstrates the necessity for an understanding of both broad scale and medium scale fauna 1 patterns.

Each of the 5 broad scale zones is discussed below in terms of polychaete feeding biology, then in terms of species distributions. Polychaete species which primarily accounted for relative proportion variations in feeding biology are included in the discussions by broad scale zone.

A number of hypotheses were posed in this study. The first. was that abundance of carnivorous polychaetes decreased with depth, percent silt-clay, and organic carbon content, and increased with course sand. Maurer and Leathem (1981) found that density of motile, jawed carnivorous polychaetes from Georges Bank increased significantly with sand and decreased with carbon during certain seasons. Boesch (1979a) observed a trend toward carnivory in coarse sediments 
Figure 14. Numerical classification of Middle Atlantic Bight stations. Classification hierarchies are indicated at left. Sampling sites of each site group are in Table 4 (Bray-Curtis similarity, flexible sorting, beta $=-0.25)$. 


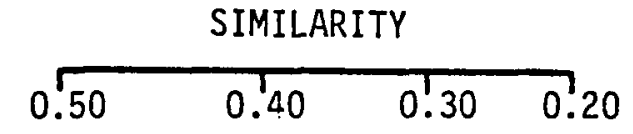

Dynamic Inner She If

(Fine Sand)

Dynamic Inner Shelf

Dynamic Middle Shelf

Inner Shelf

Dynamic Middle Shelf

(Fine Sand)

Dynamic Middle-Outer Shelf

Inner Shelf Swales

(Pre-Hypoxia)

Middle-Outer Shelf Shallow Swales

Outer Shelf Flanks -

Deep Swales

Sheif Break

$(85-95 \mathrm{~m})$

Shelf Break (90 - $110 \mathrm{~m})$

Shelf Break (130 - $140 \mathrm{~m})$

Upper Slope $(310-400 \mathrm{~m})$

Middle Slope $(450-750 \mathrm{~m})$

1

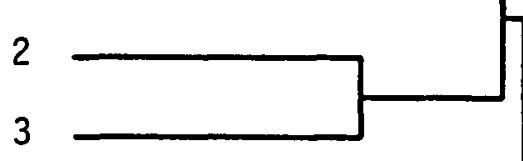

4

5

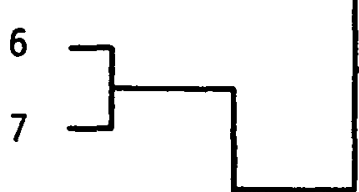

8

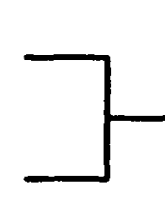

10

11

12

13

14 
Table 4. Site groups selected from numerical classification of polychaetes collected at stations across the shelf and slope. Sites are identified by station and cruise.

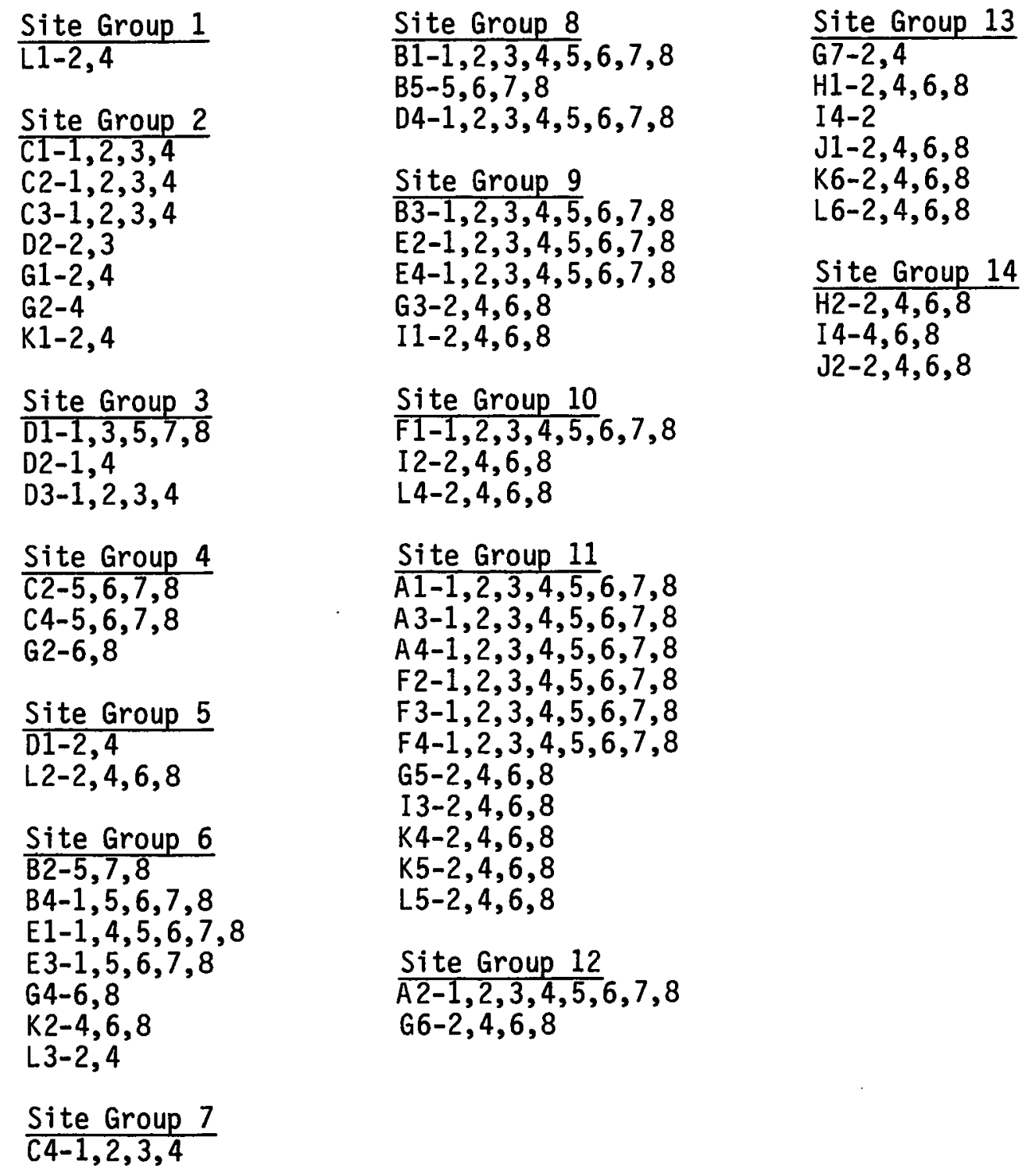


of the Middle Atlantic Bight, so a relationship between sediments and carnivorous species was expected in this study.

Other hypotheses tested in this investigation pertained to the proportions of the three components of detritivores (suspension feeders, surface deposit feeders, and subsurface deposit feeders), and their relationship with sediment characteristics and other parameters variable from habitat to habitat. Boesch (1979a) reported that surface deposit feeders numerically dominated portions of the Middle Atlantic Bight, and attributed this to a response of the benthic community to influx of organics from water column production. Though Boesch primarily limited his analyses to dominant macrofaunal species and this study was limited to the Polychaeta, the same trends were expected. Relatively lower proportions of suspension feeders were expected to inhabit the middle slope, because suspended organics would predictably be less available there. Similarly, less tube-dwelling suspension feeders would be expected in physically unstable habitats such as the inner shelf where sediments would be periodically scoured.

Finally, hypotheses concerning polychaete motility were tested. Jumars and Fauchald (1977) found significantly greater proportions of of sessile polychaetes with depth across the continental shelf, then a trend toward motility at bathyal and abyssal depths. They believed the relationship was due to sediment stability and flux of organic matter. Maurer and Leathem (1981) did not find a similar correlation, perhaps because their samples were limited to $600 \mathrm{~m}$ depth and their continental shelf samples were taken in areas of complex topography. They did 
conclude that sessile polychaetes generally inhabited more stable sediments, and motile species were more abundant in coarser grained sediment. In this study the investigator tested whether the distributions of motile, discretely motile, and sessile polychaetes were associated with depth and sediment variables.

\section{Feeding Biology}

The proportions of feeding biology components are presented in Figure 15. Carnivorous and herbivorous species were omitted from the upper portion of the figure so that the three detritivore components were better compared. Herbivorous polychaetes were uncommon in the study area, and never contributed over $2 \%$ of the polychaetes. A11 other components of the classification are included.

There was a significant negative correlation between the proportion of surface deposit feeders and increasing depth across the shelf $(r=-0.944, \quad \alpha \leq 0.05)$, an increase at the shelf break, and a slight decrease down the slope. Proportion of subsurface deposit feeders increased significantly with depth across the shelf $(r=0.982$, $\alpha \leq 0.01$ ), decreased at the break then increased aga in down the slope. Suspension feeders were in greatest relative abundance at intermediate shelf depths, and were very poorly represented on the inner shelf and middle slope.

Motile polychaetes numerically dominated all depth zones (Figure 15). The proportion of sessile polychaetes was positively correlated with both organic carbon $(r=0.999, \alpha \leq 0.05)$ and percent silt and clay $(r=0.998, \alpha \leq 0.05)$ in non-swale habitats on the shelf. The 
Figure 15. Percentage of polychaete feeding, motility and morphology by major habitat. Carnivores and herbivores are excluded. [subsurface deposit feeders (B); surface deposit feeders (S); suspension feeders (F); discretely motile (D); motile (M); sessile (L); jawed (J); soft proboscis $(X)$; tentaculate $(T)$; pumping $(P)]$. 


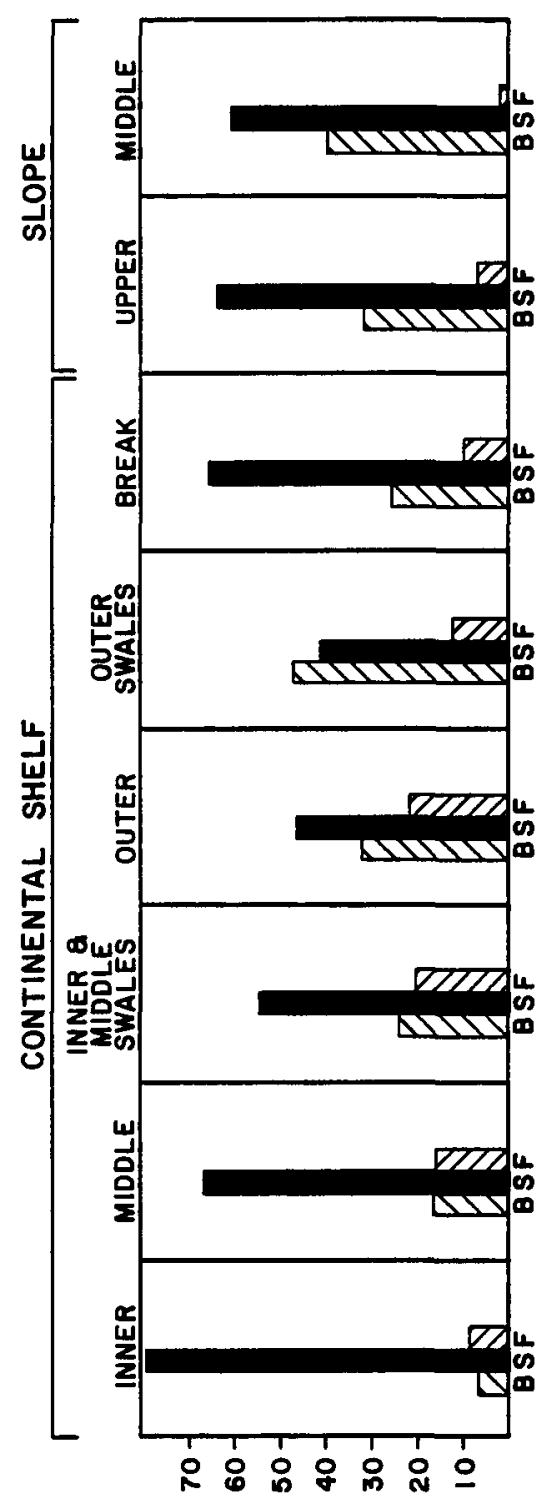

(\%) 9N1033y

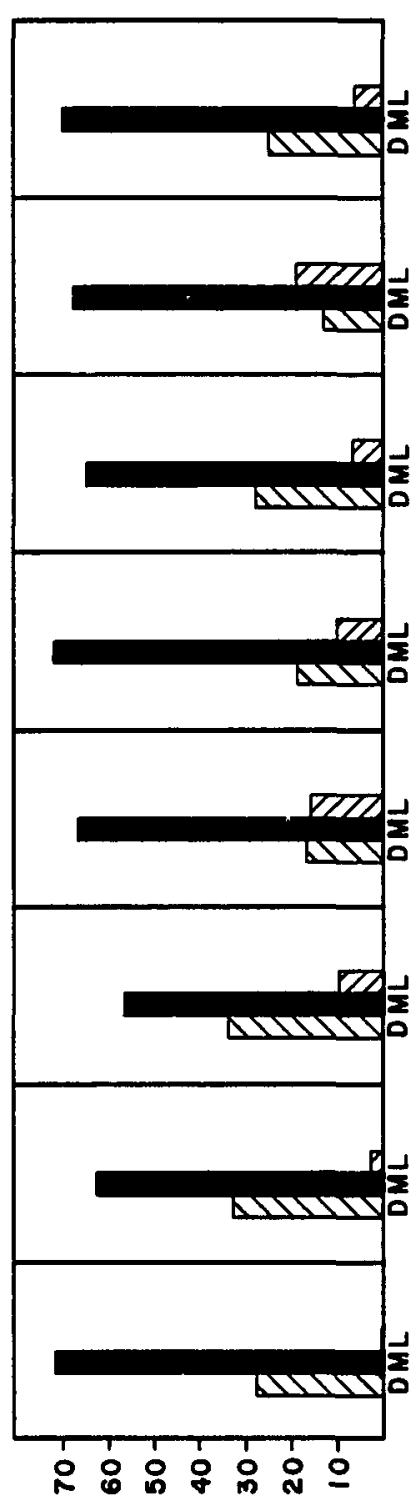

(\%) ג1I7ILOW

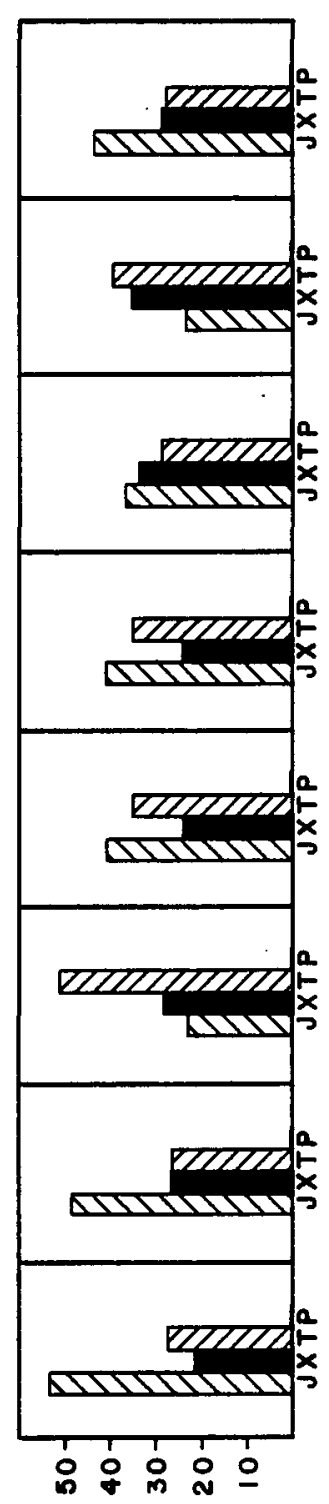

(\%) $19070 \mathrm{Hd}$ HOW 
relative proportion of sessile polychaetes was greatest at the upper slope (19\%), and was lowest on the inner shelf (less than 1\%). The proportion of discretely motile polychaetes was greatest on the inner (28\%) and middle shelf (33\%) and at the shelf break (28\%).

The polychaete morphological components are presented for comparison at the bottom of Figure 15. Jawed polychaetes were in greatest proportion at non-swa le habitats of the inner (53\%) and middle shelf (48\%), and were in considerably less proportion (23\%) at inner and middle sheif swales (topographic lows). Tentaculate polychaetes were abundant in all zones, but in greatest proportion in the inner and middle shelf swales (51\%). Only a single species, Spiochaetopterus oculatus, was included in the class "pumping". This species was not abundant in the Middle Atlantic Bight. It contributed less than $1 \%$ of the polychaetes in the zones here examined, and was excluded from subsequent analyses.

Carnivorous polychaetes were in greatest proportion in the inner (53\%) and middle shelf zones (40\%) and in least proportion at the shelf break (7\%). There was a negative correlation $(r=-0.970, \alpha \leq 0.05)$ between percentage of carnivorous polychaetes and increasing depth across the shelf. Carnivorous polychaetes were also negatively correlated $(r=-0.757, \alpha \leq 0.05)$ with organic carbon from the inner shelf to the slope.

As will be demonstrated below, it became apparent that longshore variability in abundance of carnivorous polychaetes in the study area was too great to demonstrate significant associations of polychaetes 
with sediment variables of combined depth zone transects. For this reason, the transects of stations $G 1-G 7, K 1-K 6$, and $L 1-L 6$ (Figure 3 ) were analyzed separately. Carnivorous polychaete relative abundance to other feeding components was negatively correlated with organic carbon $(r=-0.788, \alpha \leq 0.05)$, percent silt and clay $(r=-0.791, \alpha \leq 0.05)$, and median diameter of sediments $(r=-0.828, \alpha \leq 0.05)$ from the inner shelf to the slope in transect $G$. There was a strong negative correlation $(r=-0.920, \alpha \leq 0.01)$ between carnivorous polychaetes and organic carbon along transect $K$. None of the above parameters were significatly correlated with proportion of carnivorous polychaetes in transect $L$. These variations between transects probably resulted, at least in part, from the differences between sediments of the northern and southern Middle Atlantic Bight inner and middle shelf. Generally the northern areas graded from coarse to fine sediments with depth, whereas the inner and middle shelf surficial sand off Virginia was primarily fine or very fine sand. On the outer shelf the sediments of transect $L$ were anomalously coarser than were inner shelf sediments. The polychaetes which dominated the sediments of the different areas also varied dramatically, as will be demonstrated below.

Figures 16 through 18 are ternary diagrams which provide a spatial distribution model of each station by feeding, motility, and morphology classifications. Carnivorous and herbivorous species have been excluded from Figure 16. As evidenced by Figure 16, non-swale inner shelf habitats were dominated by surface deposit feeders, providing over $95 \%$ of the individuals at some stations (e.g. stations C2, C3). 
Figure 16. Tenary diagram of broad scale sampling sites identified by habitat. Sites are distributed by percentage of the three components of deposit feeding polychaetes: surface, subsurface and suspension. Mean values of sites in each habitat are plotted as centroids in sma 11 diagram at right. 


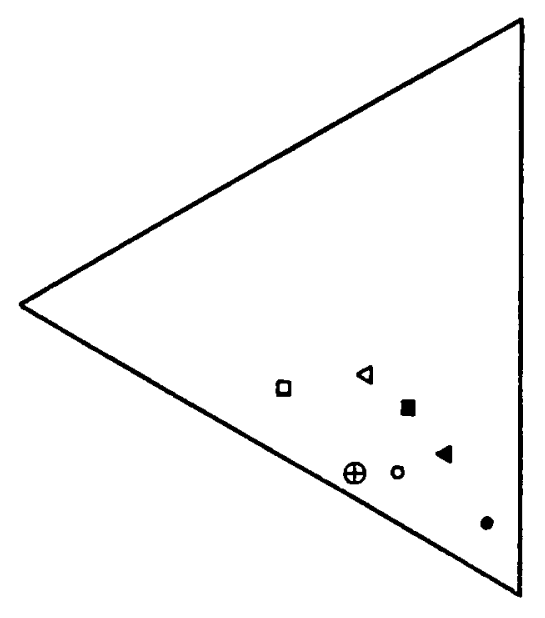


Figure 17. Tenary diagram of broad scale sampling sites identified by habitat. Sites are distributed by percentage of the three components of polychaete motility: motile, discretely motile and sessile. Mean values of sites in each habitat are plotted as centroids in small diagram at right. 


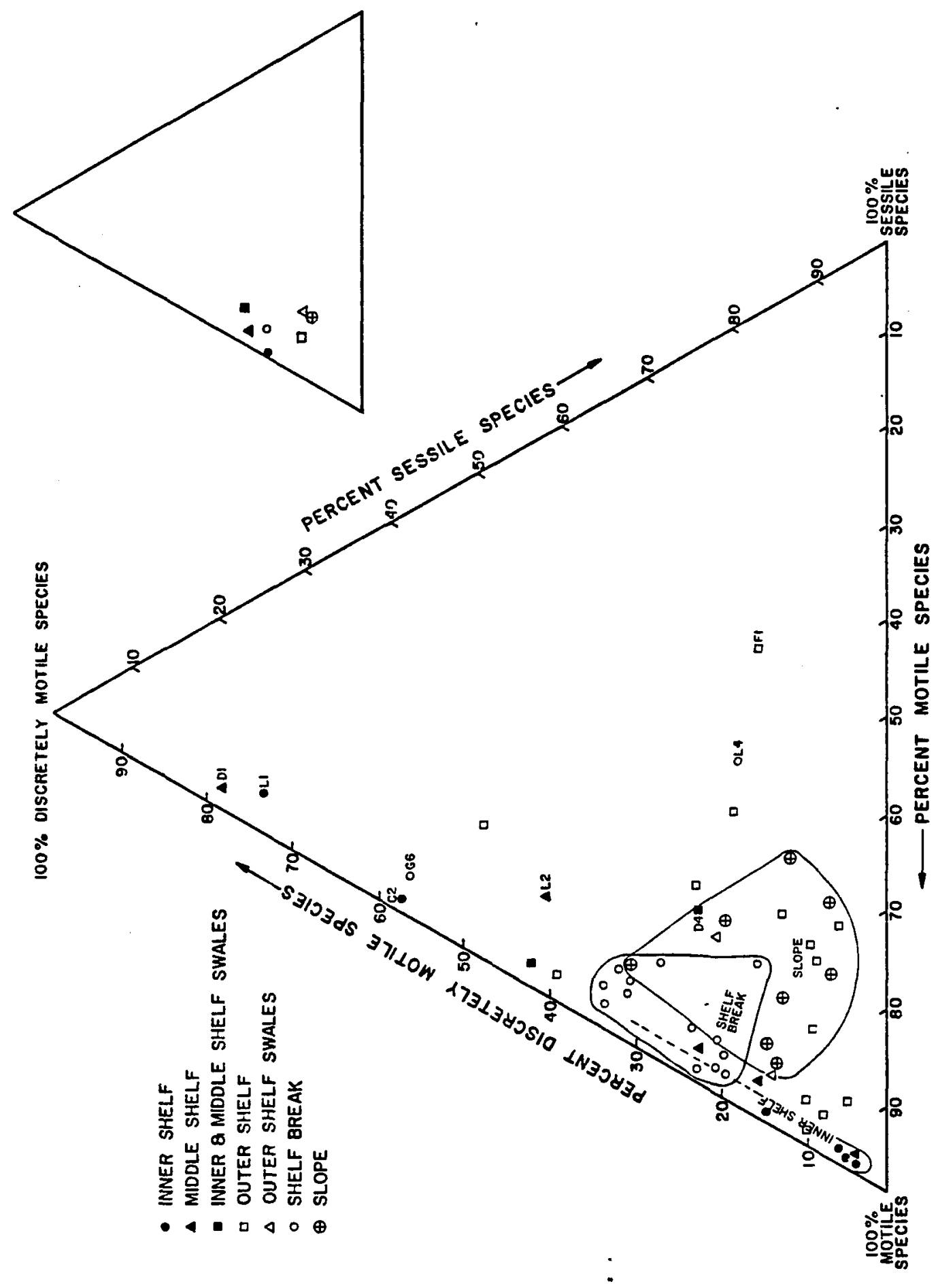


Figure 18. Tenary diagram of broad scale sampling sites identified by habitat. Sites are distributed by percentage of the three primary components of polychaete morphology: jawed, tentaculate and soft proboscis. Mean values of sites in each habitat are plotted as centroids in small diagram at right. 

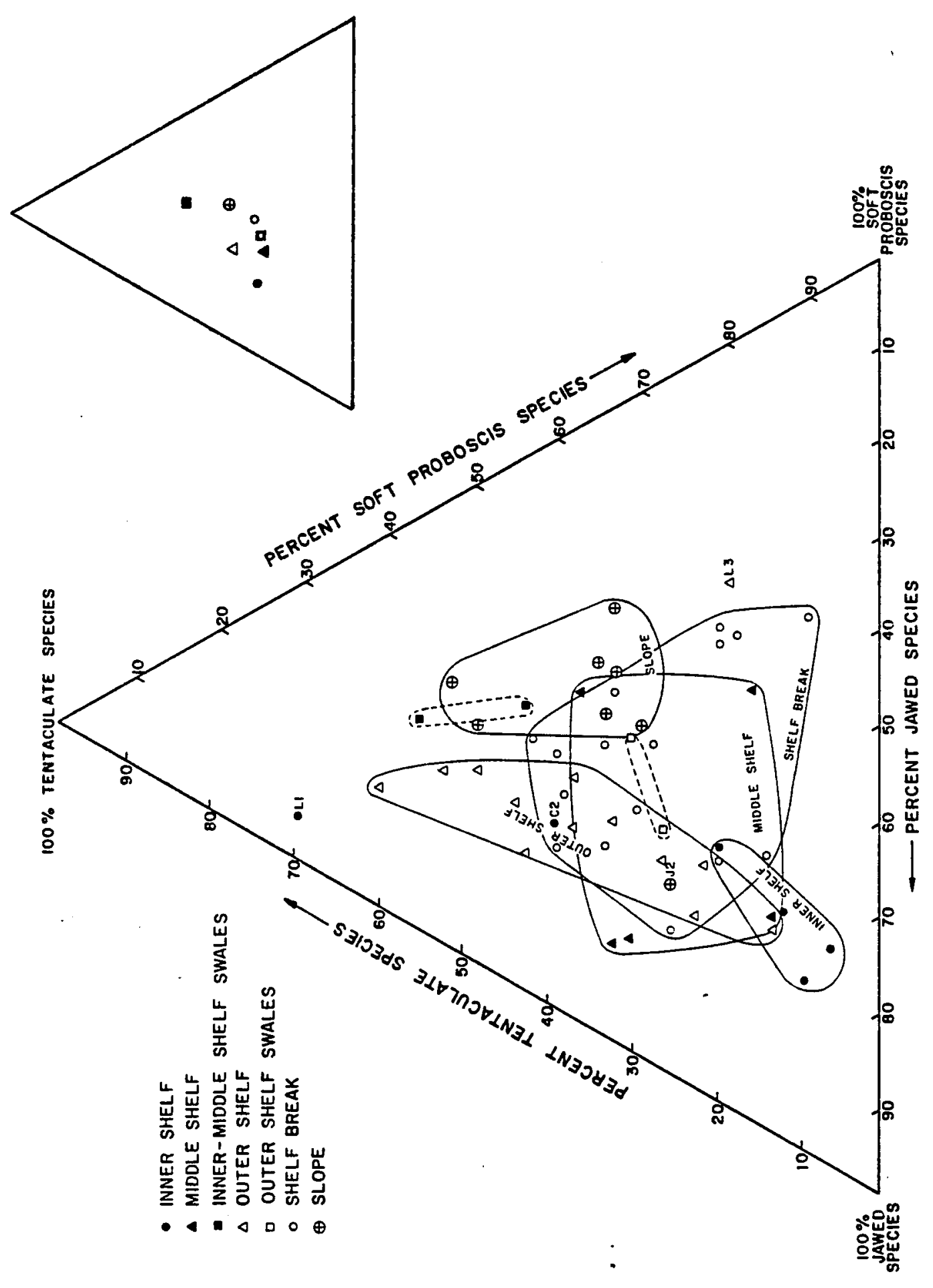
Middle shelf sites, with the notable exception of station L2, were dominated by surface deposit feeders. Station L2 was abundant in subsurface deposit feeders, primarily lumbrinerids. There was a distinction between inner and middle shelf swale habitats and other inner and middle shelf stations. The swales had a greater proportion of subsurface deposit feeders, and in that regard more closely resembled outer shelf stations. Shelf break stations generally contained a lower proportion of subsurface deposit feeders. There was an increase in proportion of suspension feeders from inner to outer shelf habitats. Shelf break stations generally contained a lower proportion of suspension feeders than non-swale outer shelf stations. Slope stations were distinguished in generally having a greater proportion of subsurface deposit feeders than the inner and middle shelf, and fewer suspension feeders than the outer shelf.

Figure 17 is the ternary diagram for motility. Most of the stations were numerically dominated by motile species. Inner shelf stations generally contained the greatest proportion of motile polychaetes. The only inner shelf stations with less than $80 \%$ motile polychaetes were station L1, a habitat of physically dynamic fine or very fine sand, and station C2 located on a ridge flank with medium-coarse sand. Both were abundant in discretely motile species, primarily magelonids and spionids (e.g. Prionospio dayi and Spiophanes bombyx). Most middle shelf sites contained less than $2 \%$ sessile species, and were widely dispersed along the discretely motile-motile axis. Outer shelf sites generally contained a greater proportion of sessile 
polychaetes than the inner or middle shelf. Station F1, a medium-fine sand habitat on the shelf break, had a greater proportion of sessile polychaetes (50\%) than any other site. This resulted from the extensive populations of Chone infundibuliformis supported there. Most shelf break stations contained 20 to 35 percent discretely motile species. Exceptions were station L4, abundant in the sessile species C. infundibuliformis, and station G6, occupied by $58 \%$ discretely motile polychaetes (e.g. onuphids and eunicids). Many slope stations were generally similar to outer shelf stations in proportion of the motility components, though as will be demonstrated below, the two zones did not share similar polychaete assemblages.

The feeding morphology ternary diagram (Figure 18) indicates the greater proportion of jawed polychaetes at most inner shelf stations. The exceptions were stations $C 2$ and $L 1$, both relatively abundant in tentaculate polychaetes (e.g. magelonids and spionids). None of the depth zones were clearly separated by morphological characteristics, though there was a trend toward more tentaculate species on the outer shelf than at shallower zones. Station $L 3$ s distinguished from other outer shelf sites due to abundance of soft proboscis polychaetes, especially orbiniids and paraonids. Slope stations generally had fewer jawed polychaetes than most other habitats. The exceptions were the inner and middle shelf swales which had similar proportions of each morphological component that inhabited the slope, but a different polychaete fauna. 


\section{Polychaete Species Distributions}

Figures 19 through 28 indicate the distribution of feeding biology classes (e.g. surface deposit feeding, subsurface deposit feeding, suspension feeding) by collection site in broad scale areas of the Middle Atlantic Bight. The figures are discussed by depth zone below. This allows comparison of habitats within each zone, and included species assemblage comparisons.

Boesch (1979a) found the New Jersey inner shelf inhabited primarily by small macrofauna and large motile megafauna including decapods and sea stars. This pattern among the benthos was severely disrupted by hypoxic and anoxic conditions of July and August of 1976. Many of the megafaunal species were temporarily eliminated from the New Jersey inner shelf, and the macrofauna subsequently became dominated by tubedwelling opportunistic species (e.g. Spiophanes bombyx, Asabellides oculata) and cerianthid anemones (Steimle and Radosh 1979). The causes and effects of the 1976 oxygen depletion were well documented in a summary by Swanson and Sindermann (1979), and therefore were not extensively detailed in this study. It should be noted, however, that the affected area extended from the inner shelf off Delaware Bay to the inner shelf off Long Island, and to the New Jersey middle shelf. Numerous of the polychaete species included in this investigation were impacted. Interstitial-feeding species such as Lumbrinerides acuta were almost completely eliminated at station $\mathrm{C} 2$, whereas populations of another interstitial-feeding polychaete, Goniadella gracilis, persisted through conditions of low oxygen. Post-hypoxia population irruptions 
Figure 19. Abundance $\left(\mathrm{m}^{-2}\right)$ of surface deposit feeding at polychaetes at sampling sites in the Middle Atlantic Bight. 


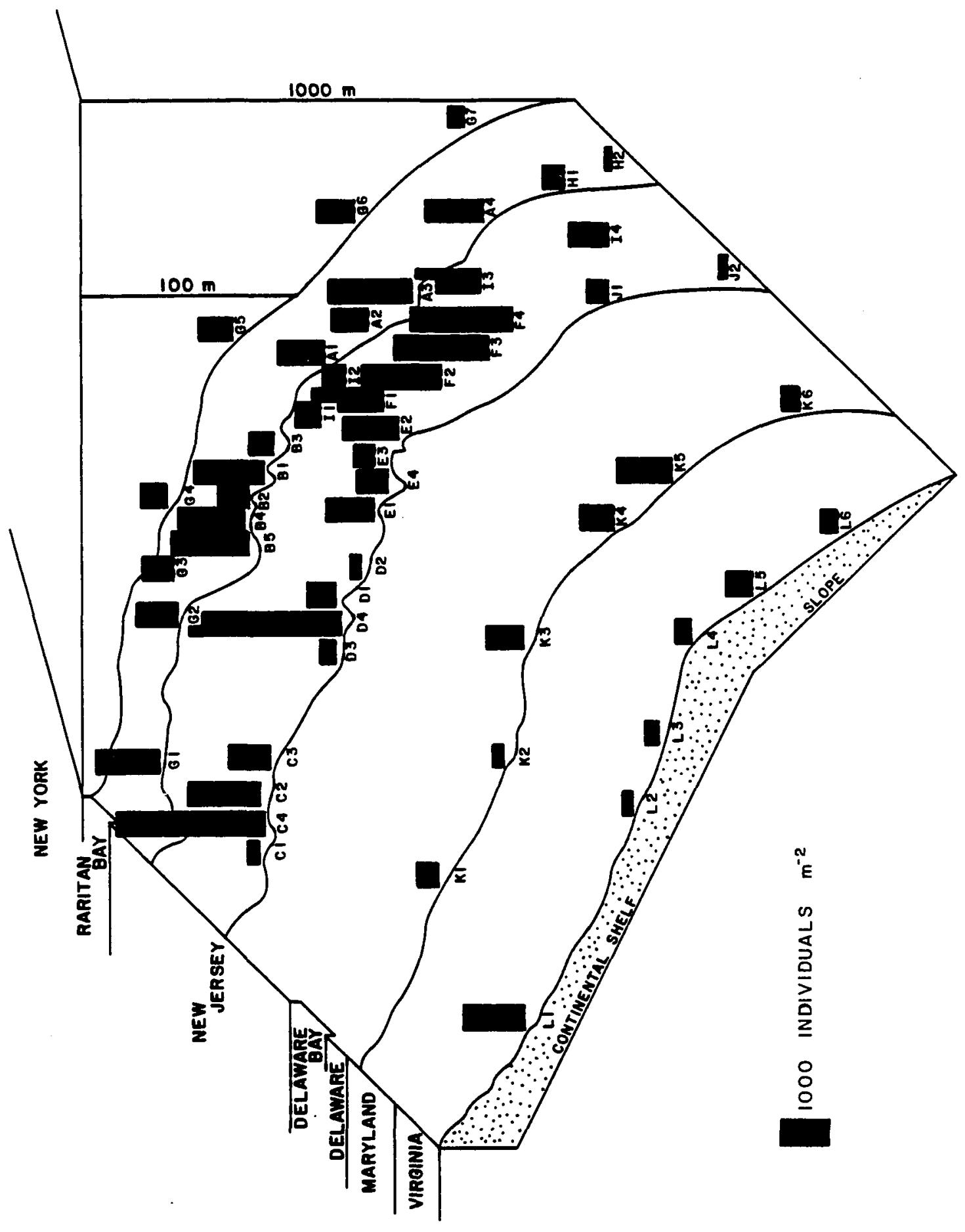


Figure 20. Abundance $\left(\mathrm{m}^{-2}\right)$ of carnivorous polychaetes at sampling sites in the Middle Atlantic. 


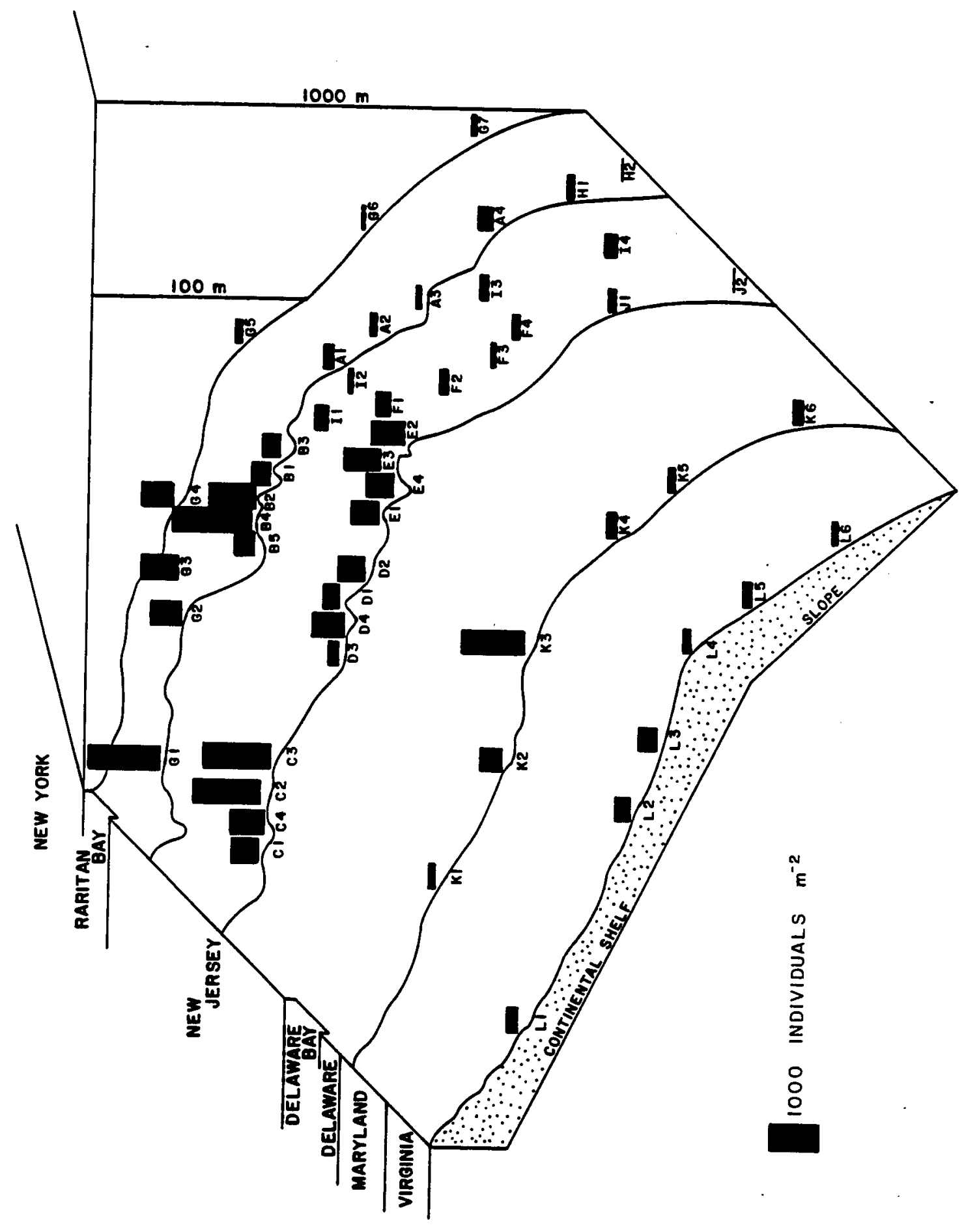


Figure 21. Abundance $\left(\mathrm{m}^{-2}\right)$ of jawed polychaetes at sampling sites in the Middle Atlantic Bight. 


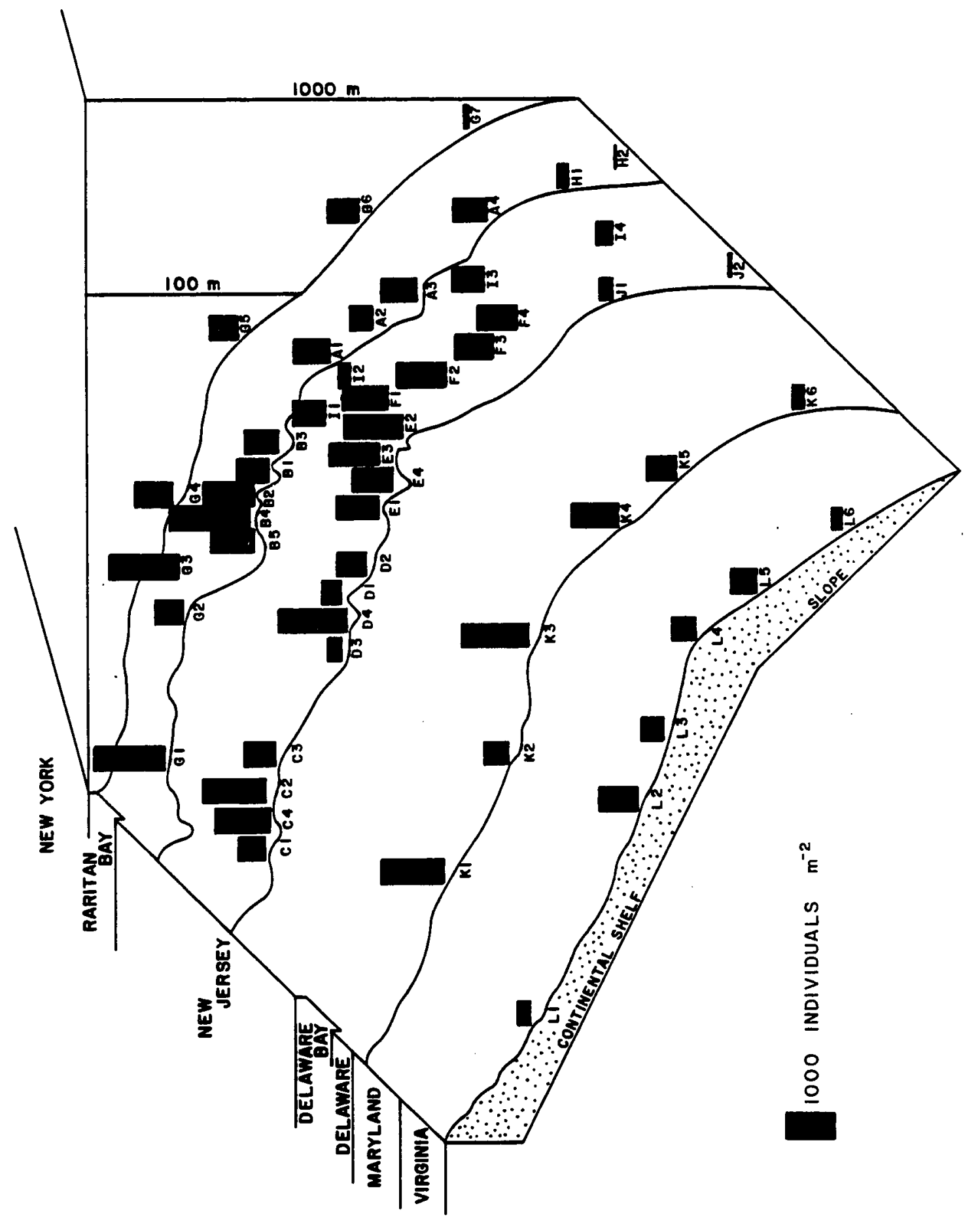


Figure 22. Abundance $\left(\mathrm{m}^{-2}\right)$ of subsurface deposit feeding polychaetes at sampling sites in the Middle A tlantic Bight. 


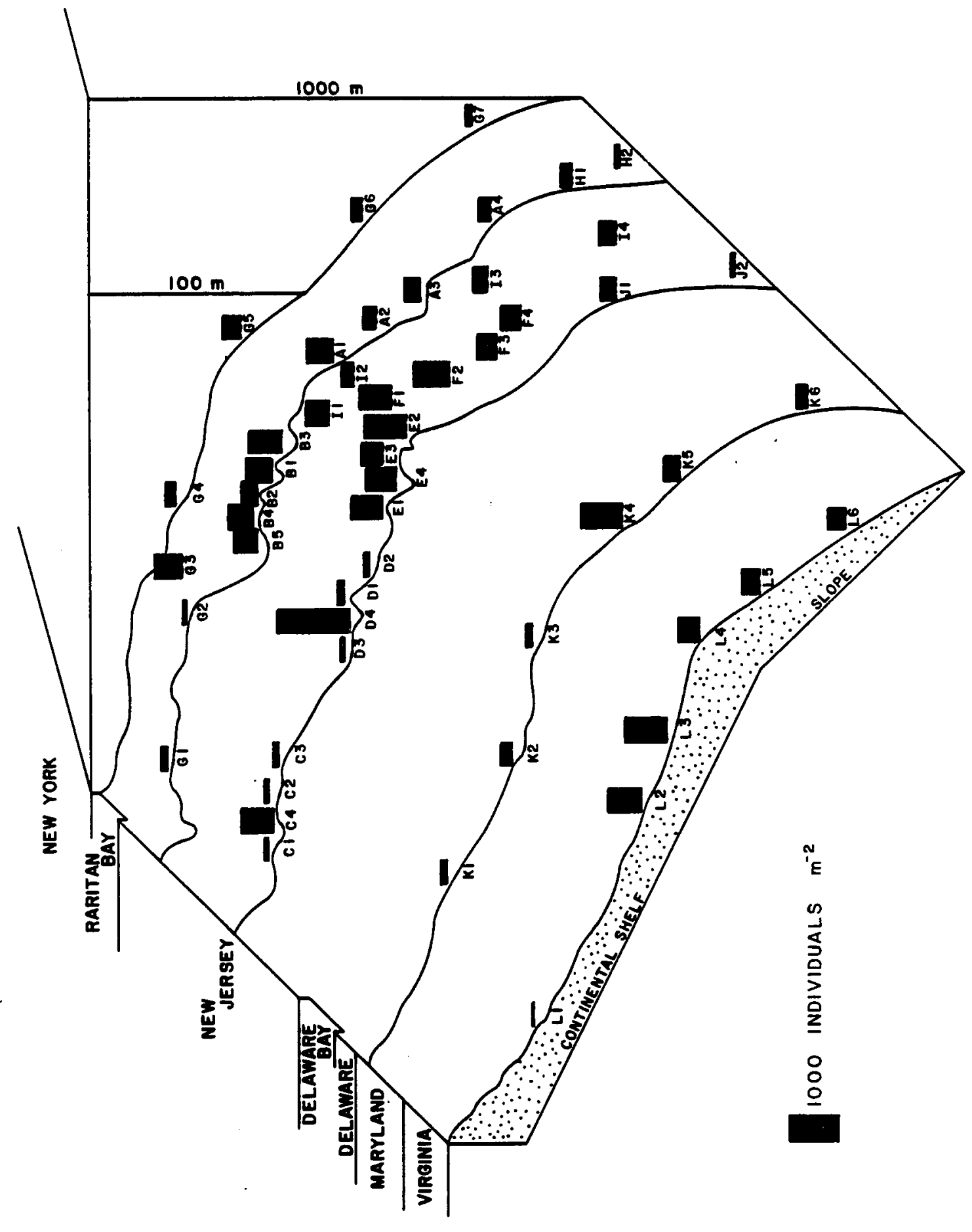


Figure 23. Abundance $\left(\mathrm{m}^{-2}\right)$ of suspension feeding polychaetes at sampling sites in the Middle Atlantic Bight. 


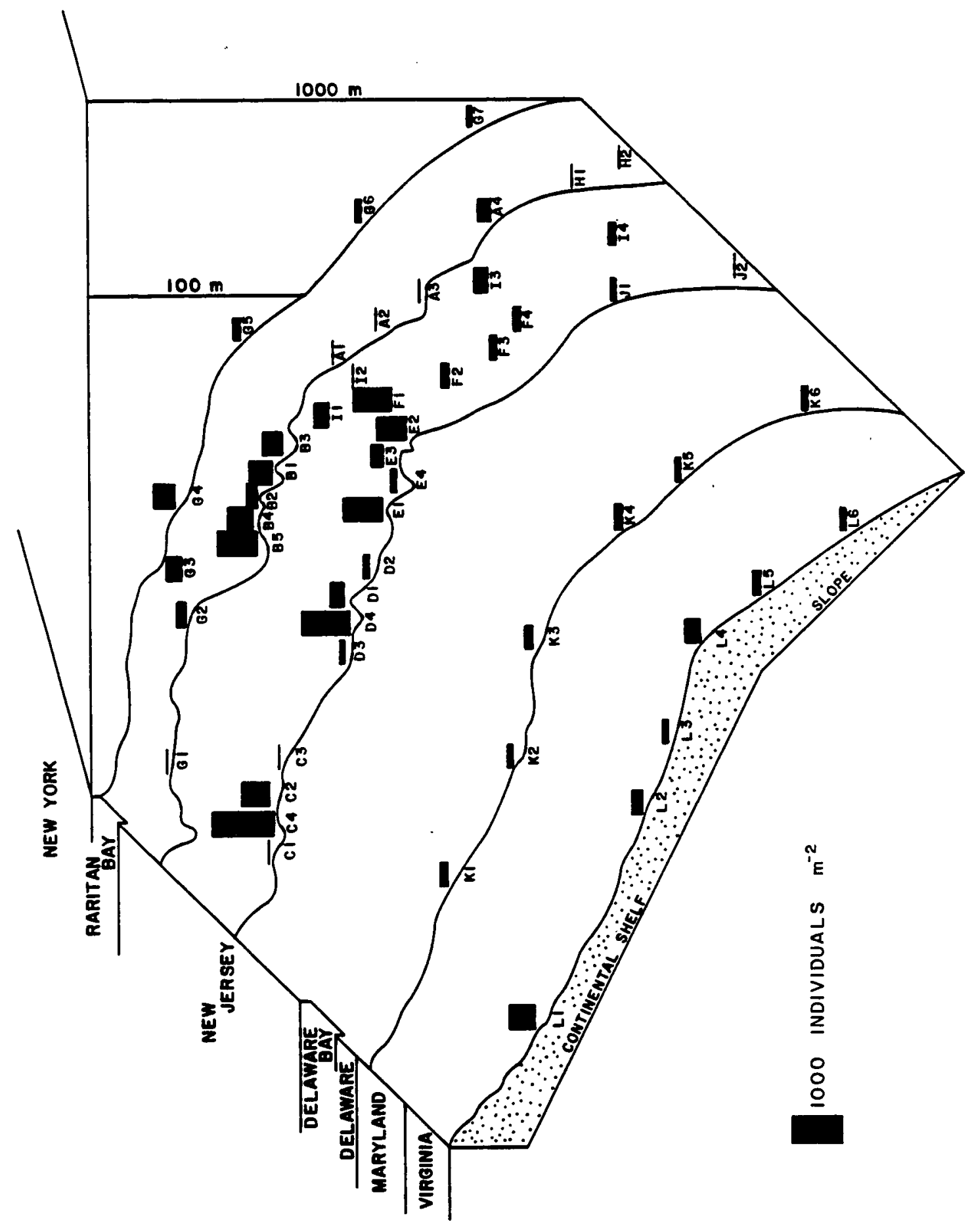


Figure 24. Abundance $\left(\mathrm{m}^{-2}\right)$ of motile polychaetes at sampling sites in the Middle Atlantic Bight. 


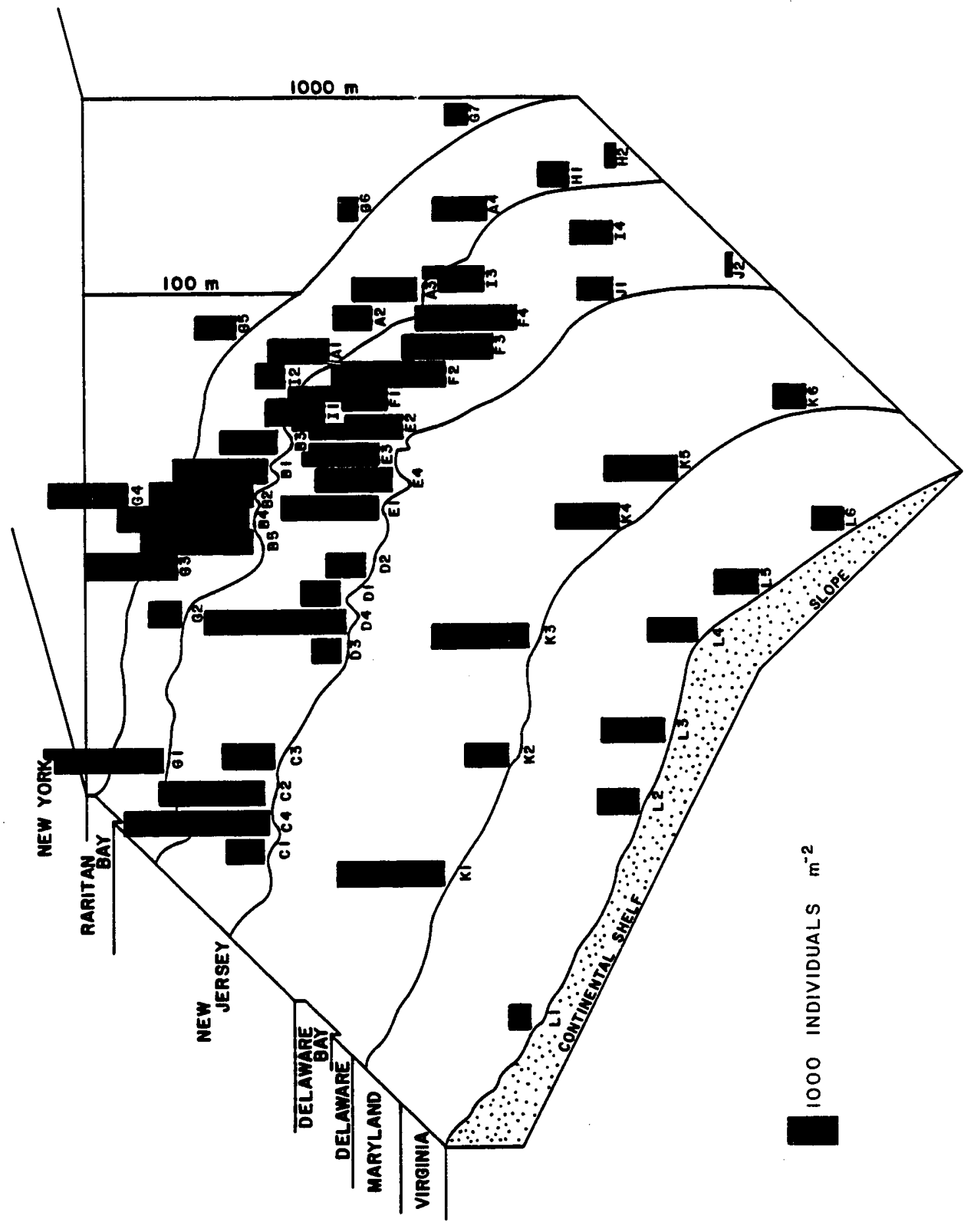


Figure 25. Abundance $\left(\mathrm{m}^{-2}\right)$ of sessile polychaetes at sampling sites in the Middle Atlantic Bight. 


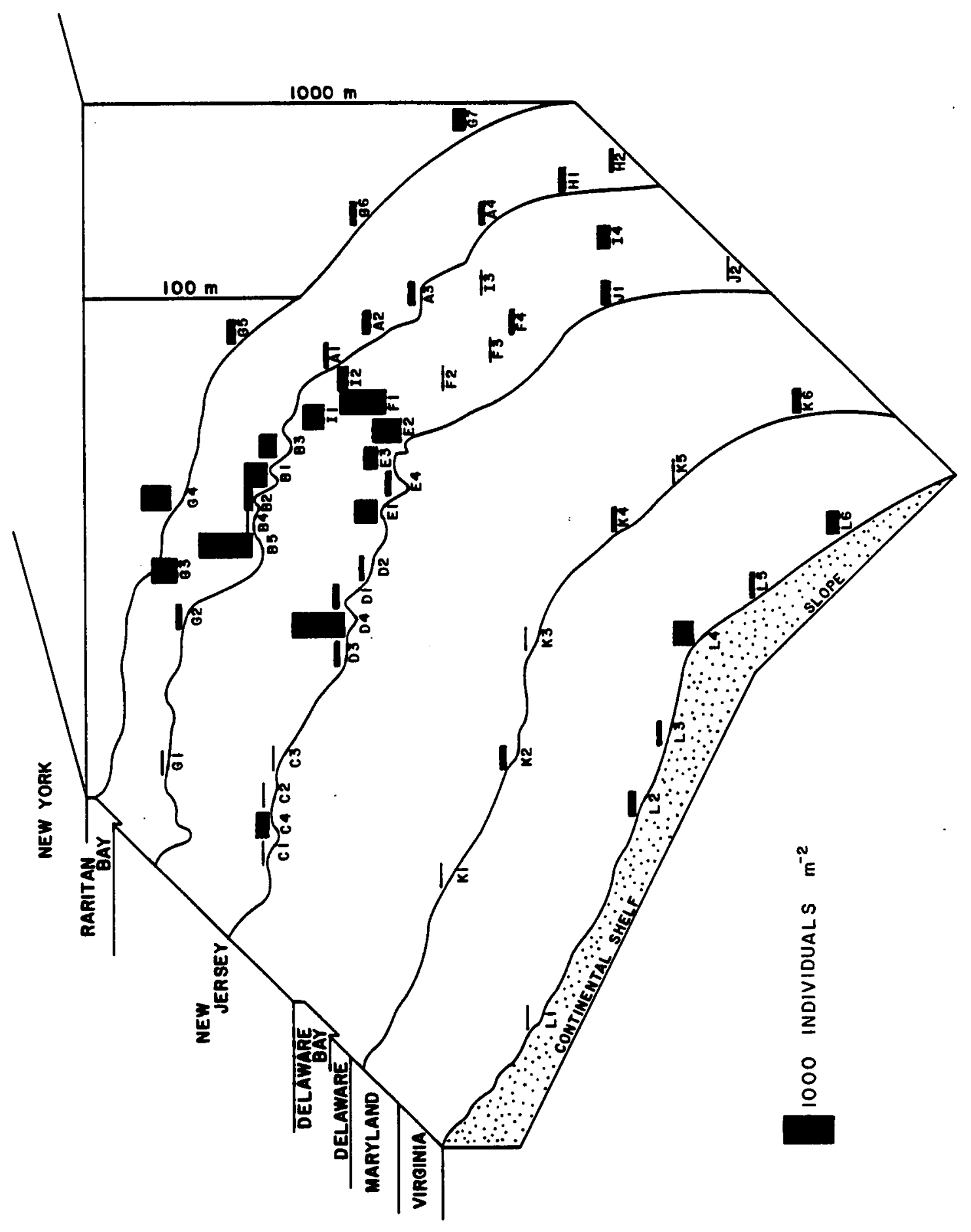


Figure 26. Abundance $\left(\mathrm{m}^{-2}\right)$ of soft proboscis polychaetes at sampling sites in the Middle Atlantic Bight. 


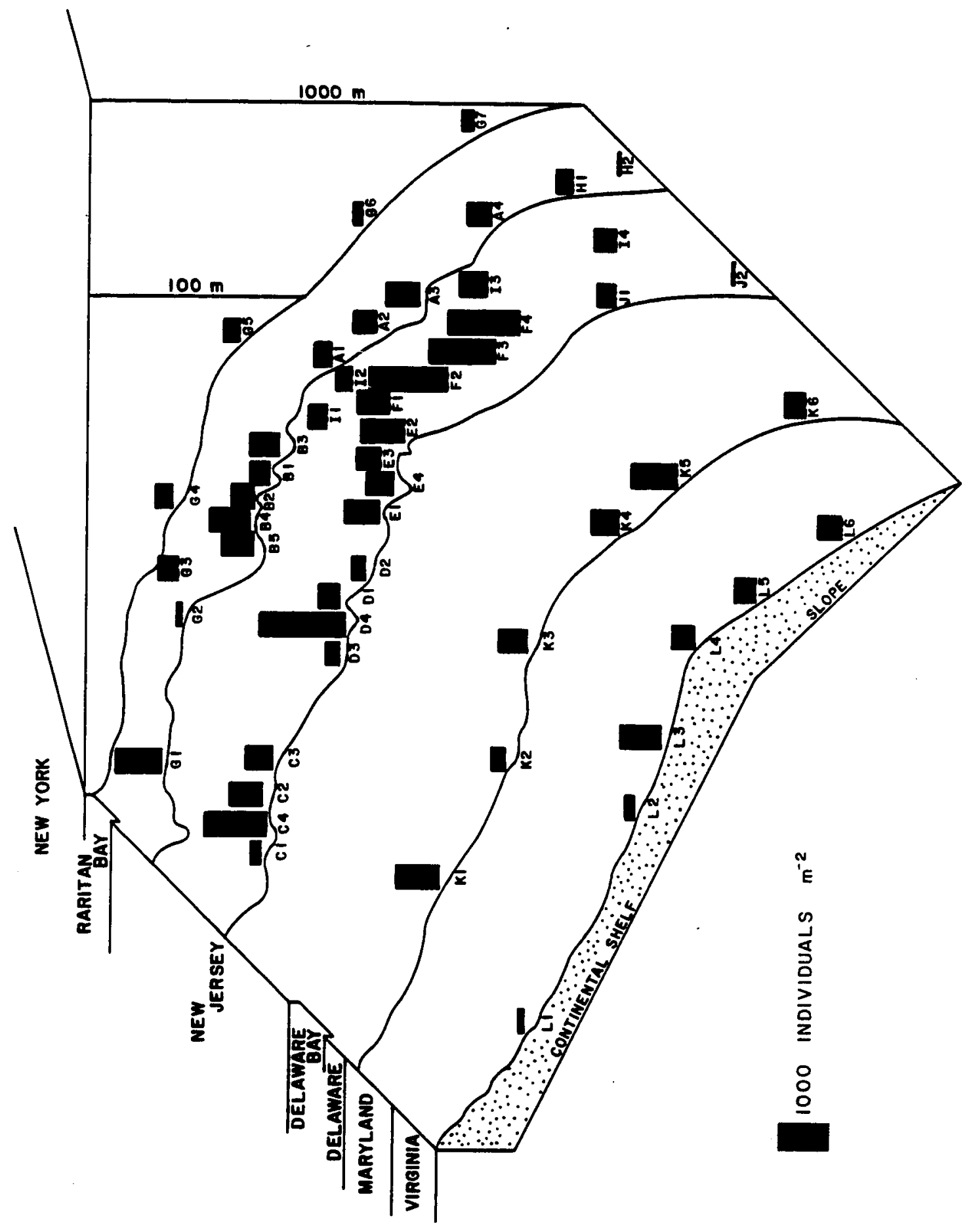


Figure 27. Abundance $\left(\mathrm{m}^{-2}\right)$ of tentaculate polychaetes at sampling sites in the Middle Atlantic Bight. 


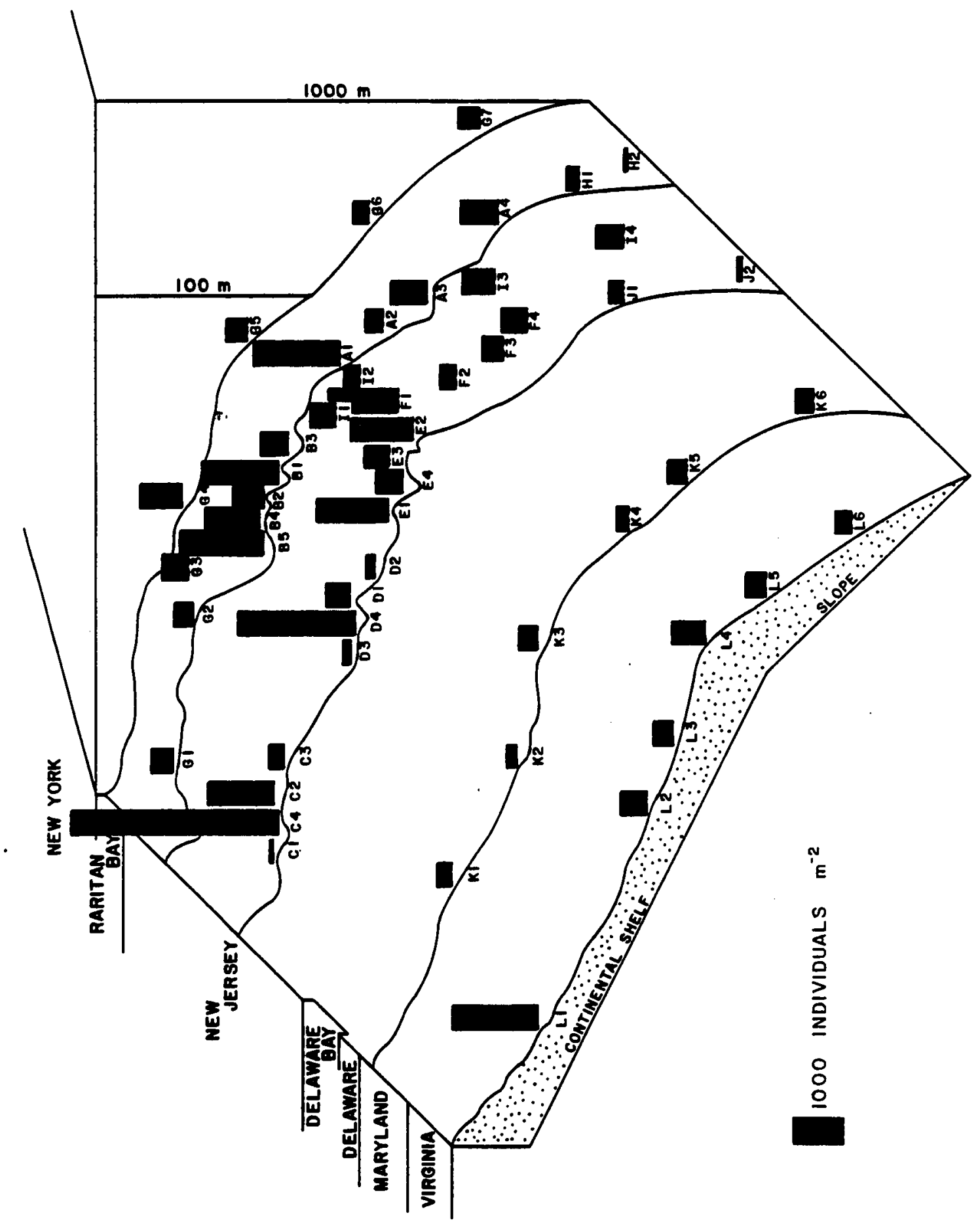


Figure 28. Abundance $\left(\mathrm{m}^{-2}\right)$ of discretely motile polychaetes at sampling sites in the Middle Atlantic Bight. 


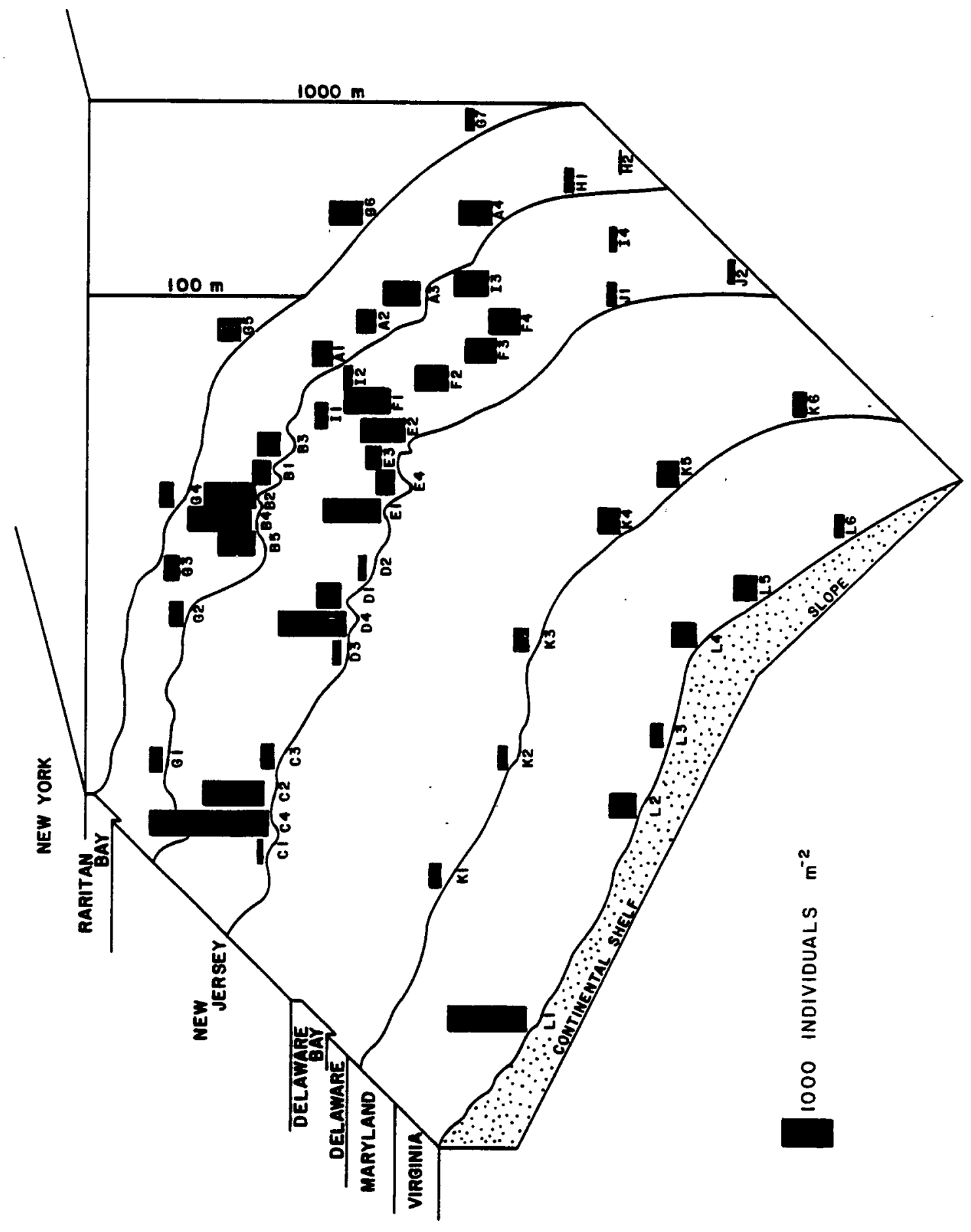


by opportunistic species such as Spiophanes bombyx drasticaliy altered the ratios of feeding classifications present before hypoxia at certain inner shelf stations.

Except in areas affected by hypoxia, the Middle Atlantic Bight inner shelf polychaete fauna ma be generally characterized as being dominated by active burrowers, some predaceous (e.g. Goniadella gracilis, Lumbrinerides acuta) in dynamic habitats, and surface or subsurface deposit feeders (e.g. Aricidea catherinae, Euclymene zonalis, Lumbrineris impatiens) in more quiescent depressions such as swales. In fine sand habitats off Virginia (station L1) where interstices between sand grains were smaller than those of the coarse sands off New Jersey, the polychaete fauna consisted primarily of burrowing species of magelonids and nephtyids and periodically species of spionids.

A total of seven inner shelf stations was sampled. These included four in ridge fields (stations (1-C4), and three on relatively level bottom (stations GI, KI, L1). The general sediment characteristics for each station are summarized in Table 1.

The feeding classification ratios of polychaetes on the inner shelf are presented in Figure 15. The inner shelf was distinguished in having lower percentages of subsurface deposit feeders and filter feeders, and higher percentages of surface deposit feeders, than the remainder of the shelf. The most abundant surface deposit feeding species on the inner shelf were Asabellides oculata, Polygordius sp. A, and Spiophanes bombyx (Table 3). Of these, only Polygordius typically 
inhabits high energy habitats on the shelf. $\underline{S}$. bombyx and $\underline{A}$. oculata are opportunistic species most abundant in shelf depressions.

Figure 19 indicates the relative abundances of surface deposit feeders across the shelf. With the exception of stations $\mathrm{Cl}$ and C4, most inner shelf sites provided habitat for about 1000 surface deposit feeding polychaetes $\mathrm{m}^{-2}$. Station $\mathrm{Cl}$ was relatively depauperate of annelids (Figure 29), while the swale habitat of station C4 was occupied by approximately 3500 surface deposit feeders.

The distributions and abundance of carnivores on the shelf is provided in Figure 20. On the inner shelf, carnivores were most abundant at stations G1 (1400 individuals $\mathrm{m}^{-2}$ ), C2 and C3 (both approximately 1250 individuals $\mathrm{m}^{-2}$ ), and least abundant at station $K 1$ (50 individuals $\mathrm{m}^{-2}$ ). Station $\mathrm{Gl}$ was the only inner shelf station with gravelly-coarse sand (Table 1). The others were medium-coarse sand habitats. The most abundant carnivores at these sites were Goniadella gracilis, Lumbrinerides acuta, and Nephtys picta. A11 typically inhabit dynamic sand habitats.

The inner shelf sites were occupied by higher percentages of jawed polychaetes than any other portion of the shelf or slope (Figure 3). Tentaculate and soft proboscis species included only $27 \%$ and $21 \%$ (respectively) of the specimens. Goniadella gracilis, Lumbrinerides acuta, and Nephtys picta contribute most of the jawed specimens. On the inner shelf these were most common at stations $C 2, K 1$, and $G 1$ (Figure 21). All were commonly collected in physically dynamic habitats. On the inner shelf these were generaliy coarse sand or graveliy 
Figure 29. Total annelids $\left(\mathrm{m}^{-2}\right)$ at sampling sites in the Middle Atlantic Bight. 


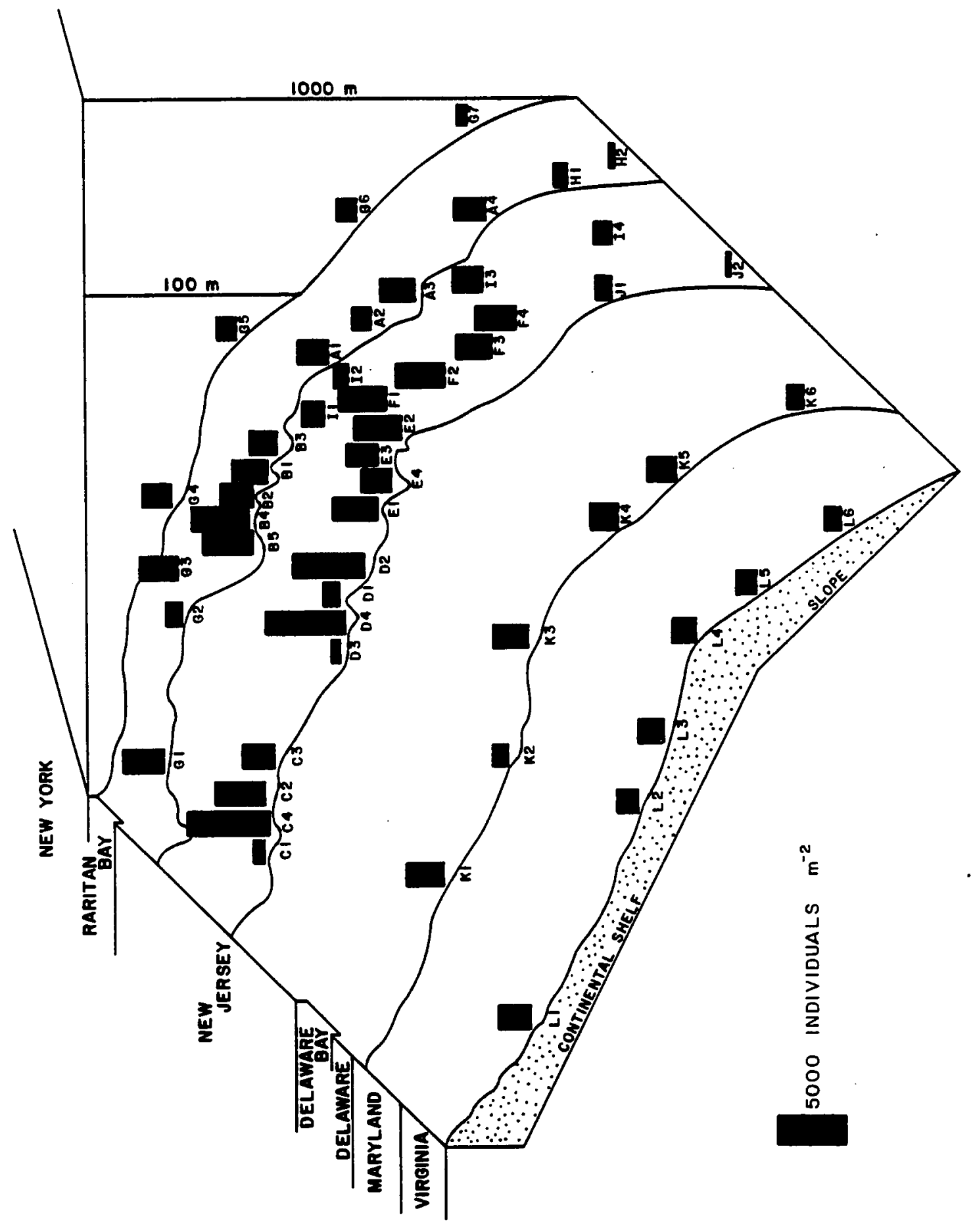


sand habitats (e.g. stations G1, K1). In this shelf zone, jawed species contributed up to 1500 individuals $\mathrm{m}^{-2}$ (Figure 21), 72\% of the polychaetes (station G1). In the fine sand of station L1, on the other hand, jawed species represented only 23\% of the individuals (219 individua $1 \mathrm{~s}^{-2}$ ).

Many of the inner shelf macrofaunal dominant species also were dominants on the middle shelf. This was expected since there were no distinct breaks between the zones. The fauna actually constitutes a coenocline, or community continuum, across the shelf of the Middle Atlantic Bight (Boesch 1979a). For instance, Spiophanes bombyx and Goniadella gracilis were abundant in both inner and middle zones of the shelf.

The middle shelf sampling included stations D1 through D4, G2 and L2. Area $D$ includes a ridge field, and each of the stations within the area is located at discrete habitats in the field (Table 1). Stations G2 and L2 are medium sand and fine sand habitats (respectively) on relatively level bottom.

Although many of the species of inner and middle shelf habitats were similar, the ratios of feeding, motility, and morphology of the poly-chaete fauna differed (Figure 15). There were more suspension feeders on the middle shelf (16\%) than the inner shelf (9\%), but fewer surface deposit feeders $(67 \%: 84 \%)$. Additionally, there were more subsurface deposit feeders $(17 \%: 12 \%)$.

Species abundant on the middle sheif that were not abundant on the inner shelf included Tharyx sp., Pherusa affinis, Glycera dibranchiata, 
Lumbrineris impatiens, Clymenella torquata, Euclymene zonalis, Aglaophamus circinata, Aricidea wassi, Aricidea cerrutii, Euchone incolor, Scalibregma inflatum, and Exogone hebes (Table 3). All had wide distribution on the shelf, but were less common in dynamic inner shelf habitats.

The feeding classifications on the middle shelf were numerically dominated by surface deposit feeders (Figure 19). At all non-swale sites the abundances of surface deposit feeders were below 600 individuals $\mathrm{m}^{-2}$. At station 04 , however, these polychaetes contributed over 2600 individuals $\mathrm{m}^{-2}$, comparable to the swale habitat (station c4) on the inner shelf. The most abundant surface deposit feeders in these swales were Polygordius sp. A, Tharyx sp., Spiophanes bombyx, and Ampharete arctica. Except in swale habitats, subsurface deposit feeders were uncommon in the middle shelf (Figure 22). Station D4 was inhabited by over 1400 individuals $\mathrm{m}^{-2}$, but other middle shelf sites generally had less than 100. An exception was the fine sand habitat of station $L 2$ which supported numerous subsurface deposit feeding species, most notably Lumbrineris impatiens. The increase in overall abundance of suspension feeders over values of the inner shelf resulted primarily from the abundance of the spionids Spiophanes bombyx and Prionospio steenstrupi and the sabellid Euchone incolor at swale station 04. Suspension feeders contributed less than 200 individuals $\mathrm{m}^{-2}$ at other middle shelf stations (Figure 23). Carnivores were generally less abundant at middle shelf sites than on the inner shelf (Figure 20). 
The motility classifications of polychaetes of the middle shelf, like the inner shelf, were dominated by motile species (Figure 15). Motile species contributed $63 \%$ of the individuals, compared to $72 \%$ on the inner shelf. Although sessile species were represented in only $3 \%$ of the total polychaetes, this value exceeded that of the inner shelf $(0.3 \%)$. The proportions of discretely motile species on the inner and middle shelf were similar (28\%:33\%, respectively). The most abundant motile species on the middle shelf were Goniadella gracilis, Lumbrinerides acuta, Lumbrineris impatiens, Aglaophanus circinata, Aricidea cerrutii, Aricidea wassi, Scalibregma inflatum, Sthenelais limicola and Exogone hebes (Table 3). Though well-represented at all stations, motile species were most abundant at station D4 (Figure 24), also the habitat most inhabited by sessile species (Figure 25). Of the above species, those motile species most common in the 04 swale were $L$. impatiens, $\underline{A}$. cerrutii and $\underline{A}$. wassi.

Like the inner shelf, most middle shelf species (48\%) were jawed (Figure 15$)$, rather than tentaculate $(26 \%)$ or soft proboscis $(26 \%)$. On the middle shelf, jawed species (e.g. Lumbrinerides acuta, Goniadella gracilis, Lumbrineris impatiens) occurred in excess of 500 individuals $\mathrm{m}^{-2}$ at most stations (Figure 21), and over $1300 \mathrm{~m}^{-2}$ at station D4.

The outer shelf included 15 sampling sites. Both ridge field areas $B$ and $E$ are on the outer shelf, and will be discussed at length with respect to medium scale distribution patterns later in this investigation. Also included on the outer shelf was station G3, located in 
the Hudson Shelf Valley, and numerous additional stations of various sediment types in areas of relatively level topography.

The classification ratios for feeding, motility, and morphology of outer shelf polychaetes are separated into two groups in Figure 15: outer shelf swales and other outer shelf stations. At the non-swale stations the polychaete fauna was dominated by surface deposit feeders (46\%), though more polychaetes on the outer shelf were subsurface feeders (32\%) and suspension feeders (22\%) than at shallower depths. of the subsurface deposit feeders which occurred in greater numbers on the outer shelf than at shallower depths, the most abundant were Notomastus latericeus, Lumbrineris latreilli, Euclymene zonalis, Ophelina acuminata, Scoloplos acemceps and Scalibregma inflatum (Table 3). The outer shelf also supported more suspension feeders, due primarily to the abundance and diversity of small sabellids and spionids at that depth zone (Table 3). These exceeded 800 individuals $\mathrm{m}^{-2}$ at some stations (Figure 23).

Carnivores (Figure 20) were more abundant on the outer shelf than in any other zone of the Middle Atlantic Bight. In the habitat of station B4 (medium-coarse sand) they exceeded 1500 individuals $\mathrm{m}^{-2}$. At that site, the most abundant carnivores were Lumbrinerides acuta and Goniadella gracilis, both active burrowers.

Most polychaetes on the outer shelf (67\%) were motile (Figure 15). These include the arabellids, capitellids, cirratulids, lumbrinerids, orbiniids, paraonids, and syllids mentioned above. Though abundant at 
a 11 outer shelf stations (Figure 24), motile species were most numerous at terrace station B4 (2600 individua $1 \mathrm{~s} \mathrm{~m}^{-2}$ ).

Morphology of outer shelf polychaetes was diverse (Figure 15), even considering the variety of habitats. In all $41 \%$ were jawed, $24 \%$ were soft proboscis species, and $35 \%$ were tentaculate. There was a relatively even distribution of jawed species on the outer shelf (Figure 21), with most habitats supporting 800 to 1200 individuals $\mathrm{m}^{-2}$. The same was true of the distribution of soft proboscis species (Figure 26), though their abundance was generally only 400 to 800 individuals $\mathrm{m}^{-2}$. Tentaculate species varied greatly with habitat, however, with the greatest numbers occupying finer sediment habitats (Figure 27). An exception was the medium-fine sand habitat of station L3, which supported less than 300 tentaculate polychaetes $m^{-2}$.

Outer shelf swales provided habitat for more subsurface deposit feeders (47\%) than surface deposit feeders (41\%), as shown in Figure 15. This resulted from a diverse group of burrowing polychaete species in swale habitats, most notably capitellids and lumbrinerids. These also accounted for the abundance of motile species in swales. Less than $7 \%$ of the total polychaete fauna in swales were sessile, mostly ampharetids and sabeliids.

The shelf break is the zone of transition between continental shelf and slope habitats, covering roughly between 100 and $200 \mathrm{~m}$ depths in the Middle Atlantic Bight. Like the outer shelf, it is an area of diverse topographic features and various sediment types. Unlike the other shelf fauna, the shelf break fauna was not abundant in wide 
depth zones, but generally occurred only in outer shelf topographic depressions and along the shelf break. Boesch (1979a) attributed this primarily to influence of the thermal regime in the area, since the sediment characteristics of the shelf break cannot solely account for the abrupt change in faunal dominants.

Fifteen sheif break stations were occupied. Most stations were in habitats of medium-fine sand (Table 1), though some were in areas of slightly finer sediments (e.g. stations $K 4$ and F2) or coarser sediments (e.g. stations I2, L4 and L5). The general sediment characteristics of the shelf break closely resembled those of outer shelf swales (e.g. station B3).

At the shelf break there was an abrupt change from the gradual pattern of less surface deposit feeders with depth, as occurred across the shelf (Figure 15). Unlike the outer shelf, which supported only $46 \%$ surface deposit feeders, and outer shelf swales with $41 \%$, the shelf break polychaetes were $66 \%$ surface deposit feeders. A pattern of greater domination by subsurface deposit feeders with depth occurred across the shelf, but at the shelf break this pattern discontinued. Only $25 \%$ of shelf break polychaetes were subsurface deposit feeders, and onty $9 \%$ were suspension feeders. The abundance of surface deposit feeders resulted from the occurrence of numerous species at the shelf break which were absent or uncommon on the shelf. The most noteworthy were Onuphis pallidula, $\underline{0}$. atlanticum, Aricidea simplex, Paradoneis lyra and Polydora caulleryi. 
The ratios of polychaete motility at the shelf break provide little indication of the distinct nature of this faunal zone. Most notable were the differences between the shelf break and outer shelf swales, two areas generally comparable in sediment type. The shelf break supported a greater percentage of discretely motile polychaetes (28\%:19\%), and less motile $(65 \%: 72 \%)$ and sessile $(7 \%: 10 \%)$ individuals. The abundance of discretely motile polychaetes on the shelf break is evidenced in Figure 28. Stations A2, A3, A4, F2, F3, F4, and I3 all supported 600-800 individuals $\mathrm{m}^{-2}$, while outer shelf swales (B3, E4) had only about 300 . The two areas had many common species. It was their abundance at the shelf break that accounted for the discrepancy. The abundances of these species were not evenly distributed among the shelf break stations (Figure 19), though a 11 supported over 500 surface deposit feeders $\mathrm{m}^{-2}$. Their greatest abundances occurred at stations F2, F3, and F4, which all have approximately $2000 \mathrm{~m}^{-2}$. The similarity between these stations is somewhat misleading, however. Among the surface deposit feeding dominants at each site were Spiophanes wigleyi and Onuphis pallidula (station F2), Aricidea simplex (station F3), and Tharyx sp. (station F4). Suspension feeders were not abundant at any of the shelf break stations (Figure 23), though they occurred at all. The most widely distributed suspension feeders were the spionids, especially species of Polydora and Prionospio. Carnivores (Figure 20) were generally not as abundant on the shelf break as on the shelf. 
The jawed, tentaculate, and soft proboscis polychaetes were represented in roughly equal numbers $(37 \%: 34 \%: 29 \%$, respectively) at the shelf break. The primary difference between polychaete fauna at the shelf break and shallower depths in terms of morphology was the diversity of jawed species (e.g. eunicids, lumbrinerids, and onuphids) at the shelf break, the diversity and abundance of soft proboscis species (e.g. paraonids and cossurids) there, and the reduced abundances of shelf break tentaculate species (e.g. sabellids and spionids). The abundance of soft proboscis species at the shelf break exceeded that of most of the shelf (Figure 26), with greatest numbers at stations F2, F3, and F4. All of these stations were rich in soft proboscis species (e.g. Notomastus latericeus, Aricidea simplex, A. catherinae, Paradoneis lyra). There were generally less tentaculate species at shelf break stations than the shelf (Figure $E$ ), due to the absence of abundant sabellids and spionids, which were numerous in ridge fields (e.g. areas $B, C, E$ ) on the shelf.

The Middle Atlantic Bight continental slope contains finer sediments than any zone on the shelf. Sediments at all stations had silt and clay in excess of $25 \%$, and those on the middle slope (i.e. stations H2, J2) had over 85\% (Table 1). Sampling included 6 stations on the upper slope ( 300 to $500 \mathrm{~m}$ depth) and two on the middle slope (650 to $750 \mathrm{~m}$ ). Like the shelf break, the slope was distinct from other depth zones. Numerous polychaetes were restricted to slope depths in the Middle Atlantic Bight, including Paramphinome jeffreysij and Ceratocephale loveni as more or less abundant species, and numerous 
rare polychaetes (e.g. Sternaspis scutata, Fauveliopsis sp. A, Praxillella gracilis). The middle slope, stations $\mathrm{H} 2$ and $\mathrm{J} 2$, supported the lowest abundance of polychaetes (Figure 29), and lowest polychaete biomass (Figure 30 ) of a 11 sites sampled. Sediments at both sites were clayey-silt.

On the slope, the polychaete fauna had a higher percentage of subsurface deposit feeders than at the shelf break, $31 \%$ on the upper slope and $39 \%$ on the middle slope (Figure 15). In that respect, the fauna more closely resembled outer shelf communities. The surface deposit feeding species were equally-well represented on the shelf break (66\%), upper slope $(63 \%)$, and middle slope $(60 \%)$. Suspension feeders on the slope, however, contributed little to the polychaete fauna, $6 \%$ (upper slope) and $1 \%$ (middle slope). The most abundant surface deposit feeders on the slope were ampharetids and paraonids (Table 3). These contributed 400 to 600 individuals $\mathrm{m}^{-2}$ at most upper slope sites (Figure 19). The increase in percentage of subsurface deposit feeders resulted from presence of abundant lumbrinerids at some sites, and perhaps more importantly, absence of the abundant onuphids, paraonids, and spionids which occurred at shallower depths. Figure 22 shows the fairly even distribution of subsurface deposit feeders among the upper and among the middle slope sites. Carnivores were generally uncommon on the slope (Figure 20), where most sites supported less than 200 individuals $\mathrm{m}^{-2}$. The only carnivores in abundance were Paramphinome jeffreysii and Hya linoecia artifex. 
Figure 30. Wet weight mean biomass $\left(\mathrm{g} \mathrm{m}^{-2}\right)$ of annelids at sampling sites in the Middle Atlantic Bight. 


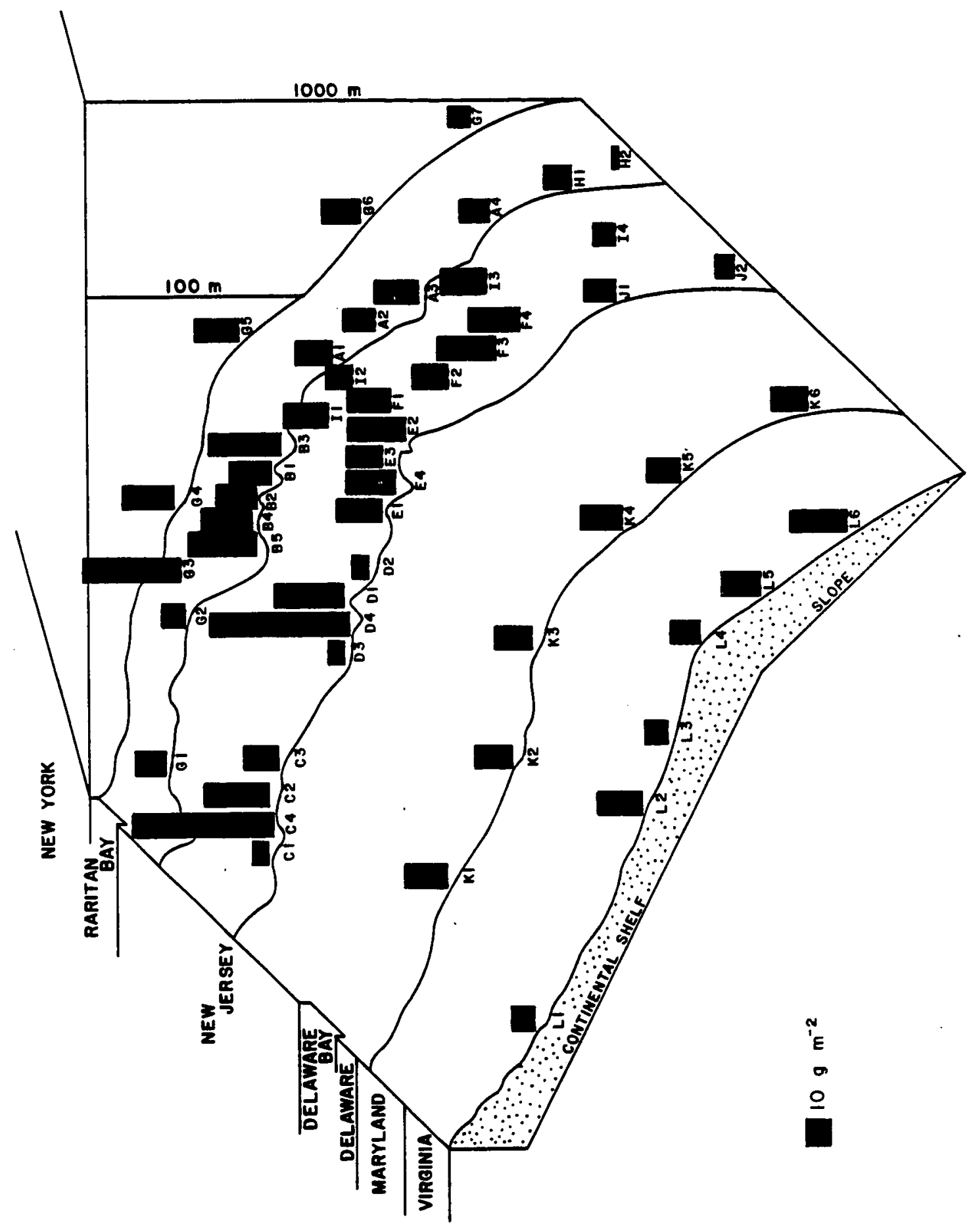


Like all other depth zones on the shelf, the slope was dominated by motile polychaetes, $68 \%$ on the upper and $70 \%$ on the middle slope (Figure 15). The abundances of $\underline{P}$. jeffreysij and $\underline{H}$. artifex were the primary reason for this pattern, which is ironic in that $\underline{H}$. artifex is a tube-dwelling species. The dominant morphology of lower slope polychaetes was anomalous in that jawed species constituted a larger percentage (44\%) than any other morphological classification. Generally, on the shelf quiescent habitats had fewer jawed polychaetes than physically dynamic ones (Figure 15). The reason for more jawed polychaetes there was the moderate abundance of lumbrinerids in these otherwise low-density habitats.

\section{Medium Scale Patterns}

The spatial distribution patterns referred to here as "medium scale" or "mesoscale" are defined as those patterns that can be discerned on a scale of hundreds to thousands of meters. Whereas broad scale patterns encompass cross-shelf and latitudinal faunal patterns, mesoscale patterns include response to local sediment and topographic features which may result in major community changes over rather short distances. Two areas of the Middle Atlantic Bight were selected for this investigation: Areas $B$ and $E$ (Figure 3 ). These areas were intensively sampled to ascertain mesoscale feeding biology and faunal patterns. Sampling procedures included stratified random sampling within a priori selected strata (Boesch 1979a). In this investigation, the results of the stratified random study were combined with quarterly 
sampling data to provide the data base for mesoscale faunal investigations.

The dominant topographic features in Areas $B$ and $E$ were those associated with ridge and swale topography. An understanding of these features is essential in ecological investigations of the areas. These features are discussed below. Specific sediment characteristics are discussed later by study area.

Ridge and swale topography consists of fields of linear sand ridges separated by topographic lows (swales). These features, their genesis and associated processes were discussed in detail by Duane et a 1. (1972) and Swift et a 1. (1972). The ridges of areas B and E (off New Jersey) trend roughly northeast to southwest about $30^{\circ}$ oblique to the shoreline (Knebel and Folger 1976).

There are two populations of ridges in the Middle Atlantic Bight, with a smaller ridge system superimposed on a larger system (Swift 1976). Off New Jersey the ridges of the inner shelf have a mean spacing of $1.4 \mathrm{~km}$ and $4.7 \mathrm{~m}$ relief. On the central shelf these structures are $2.5 \mathrm{~km}$ apart and $6 \mathrm{~m}$ high, while those of the outer shelf are spaced $6.1 \mathrm{~km}$ and 6-10 $\mathrm{m}$ high (McKinney et a1. 1974). Ridges of the inner shelf are believed to be less than 11,000 years old and those of deeper water somewhat older (Swift et a1. 1973).

The ridges exhibit a characteristic sediment textural pattern related to their genesis and maintenance. Grain-size profiles across ridges are asymmetrical. Sands are coarsest in the landward flank, constant across the ridge crest, and finer again on the seaward flank 
(Stanley and Swift 1976, Swift et al. 1977). Finer grained sediments (fine sands with small amounts of silt and clay) are deposited in the swales under fair weather conditions, because these less dynamic areas serve as a sediment sink. On the other hand, periodic scouring of the swales by storm-induced currents may erode the fine sediments and cut into underlying cohesive lagoonal silty clay. Thus, although muddy fine sands are typically found in swales, erosional windows containing poorly sorted sediments (including clay lumps, shell and coarse sand and gravel lag) may a iso be encountered ( $F$ igure 31 ).

Before investigations by Boesch (1979a) little attention had been focused on the ecology of the Middle Atlantic Bight benthos mesoscale faunal patterns. Boesch identified assemblages of macrobenthos for each habitat type. He found coarser sediments of dynamic areas (e.g. ridge crests) were populated by interstitial organisms and deposit feeders utilizing recently sedimented surface floc. Finer, more stable sediments of topographic depressions (e.g. swales) had sediments with small interstices which precluded interstitial feeding. These depressions were populated by a variety of deposit feeders, mostly polychaetes, which took advantage of the abundant sedimented organic matter.

Boesch's conclusions were based primarly on distribution of dominant species of macrobenthos. Since the present study included all polychaete species, and many that were reclassified following gut content analyses, the conclusions of Boesch were reexamined. Several hypotheses were here posed concerning mesoscale distribution patterns. 
Figure 31. Evolution of ridge and swa le topography (Stubblefield and Swift 1976). 

A Retreating shoreline left surficial sand sneet on eariy Holocene clay; internal stratification of ridges indicates growth by
tateral and crestal aggradation.

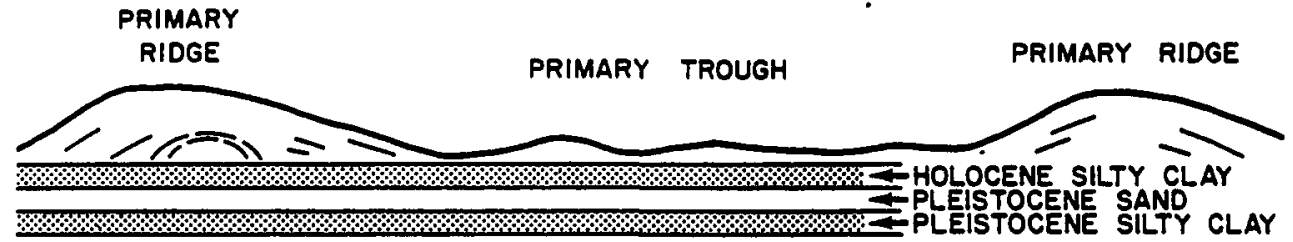

(B) Continued scour in troughs results in incision of secondary troughs into upper silty clay layer; secondary ridges may appear as levee like forms associated with secondary troughs.

PRIMARY

RIDGE

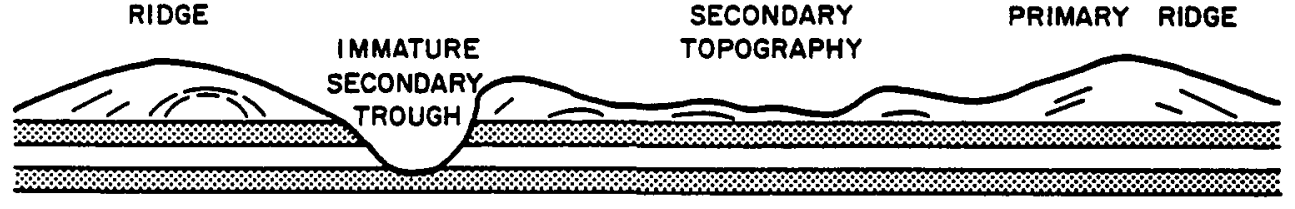

(C) Downward erosion in secondary troughs inhibited by lower silty clay; secondary trough widens by erosion of Pleistocene Sand and und ermining of upper silty clay. PRIMARY RIDGE

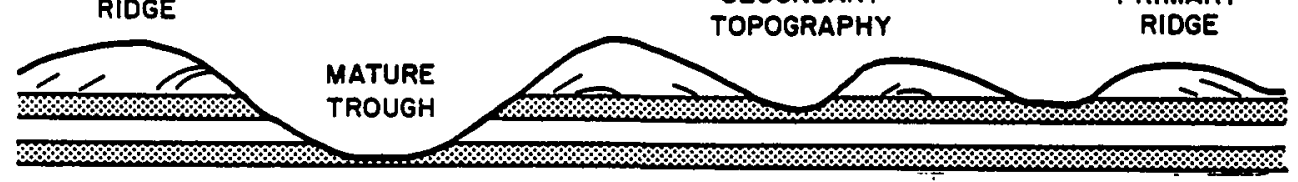


First, it was hypothesized that the proportions of the three detritivore components (suspension, surface deposit, and subsurface deposit feeders) were related to sediment variables. Using all macrobenthic taxa, Boesch (1979a) had demonstrated trends toward dominance of subsurface deposit feeders in topographic depressions (swales) and dominance of surface deposit feeders in middle range sediments. It was expected, therefore, that subsurface deposit feeders would be associated with finer sediments and greater organic carbon content. Surface deposit feeders were expected to be in greater proportion in coarser sediment habitats such as ridges and ridge flanks.

It was also hypothesized that the distribution of carnivorous polychaetes was related to sediment variables. Boesch (1979a) observed a trend toward dominance of carnivorous macrobenthic species in coarse sediments. Maurer and Leathem (1981) found the density of motile, jawed carnivorous polychaetes associated with coarse-grained sediment. It was expected, therefore, that the coarse sediment habitats of Areas $B$ and $E$ would have a greater proportion of carnivorous polychaetes than finer sediment habitats.

Another hypothesis tested was that polychaete motility was related to sediment variables. The previous investigations of polychaete distribution using the Jumars and Fauchald (1977) classification primarily concerned broad scale patterns in polychaete motility. However, since Jumars and Fauchald (1977) and Maurer and Leathem (1981) a 11 concluded that sessile polychaetes generally inhabited more stable sediments, it was here proposed that similar patterns could be demonstrated in Areas 
$B$ and $E$. It was expected that motile polychaetes would be in greatest proportion in coarser sediment habitats and sessile species would be in greatest proportion in finer sediment habitats.

It was hypothesized that the distribution of polychaete morphological classes was associated with sediment variables. Since Maurer and Leathem (1981) had shown that the feeding guilds which included most jawed polychaetes (CMJ and HMJ) were positively correlated with coarser sediments, it was expected that jawed polychaetes in Areas B and $E$ would similarly be associated with coarser sediments. Additionally, it was expected that soft proboscis polychaetes would be in greater proportion in topographic depressions and other areas high in organic carbon content, since many of the deposit feeders which Boesch (1979a) found dominant in topographic depressions were soft proboscis polychaetes.

\section{Area B Feeding Biology}

A rea $B$ includes both deep ridge and swale topography $(60$ to $75 \mathrm{~m}$ depth), and a portion of a terrace (40 to $42 \mathrm{~m}$ depth) shoreward of a sea level still stand. The individual habitats of the area are shown in Figure 32. In genera 1, the terrace and ridge crests are medium-coarse sand habitats. Fine-skewed medium sand is found on the escarpment base below the terrace. Sediments grade into muddy fine sand in a large swale east of the scarp and in the deeper swale to the southeast. Sediment parameters and depth of each habitat sampled in Area B are provided in Table 5 . 
Figure 32. Distribution of major habitats in Area $B$. Quarterly and stratified random sampling sites are identified by points (redrawn from Boesch 1979). 


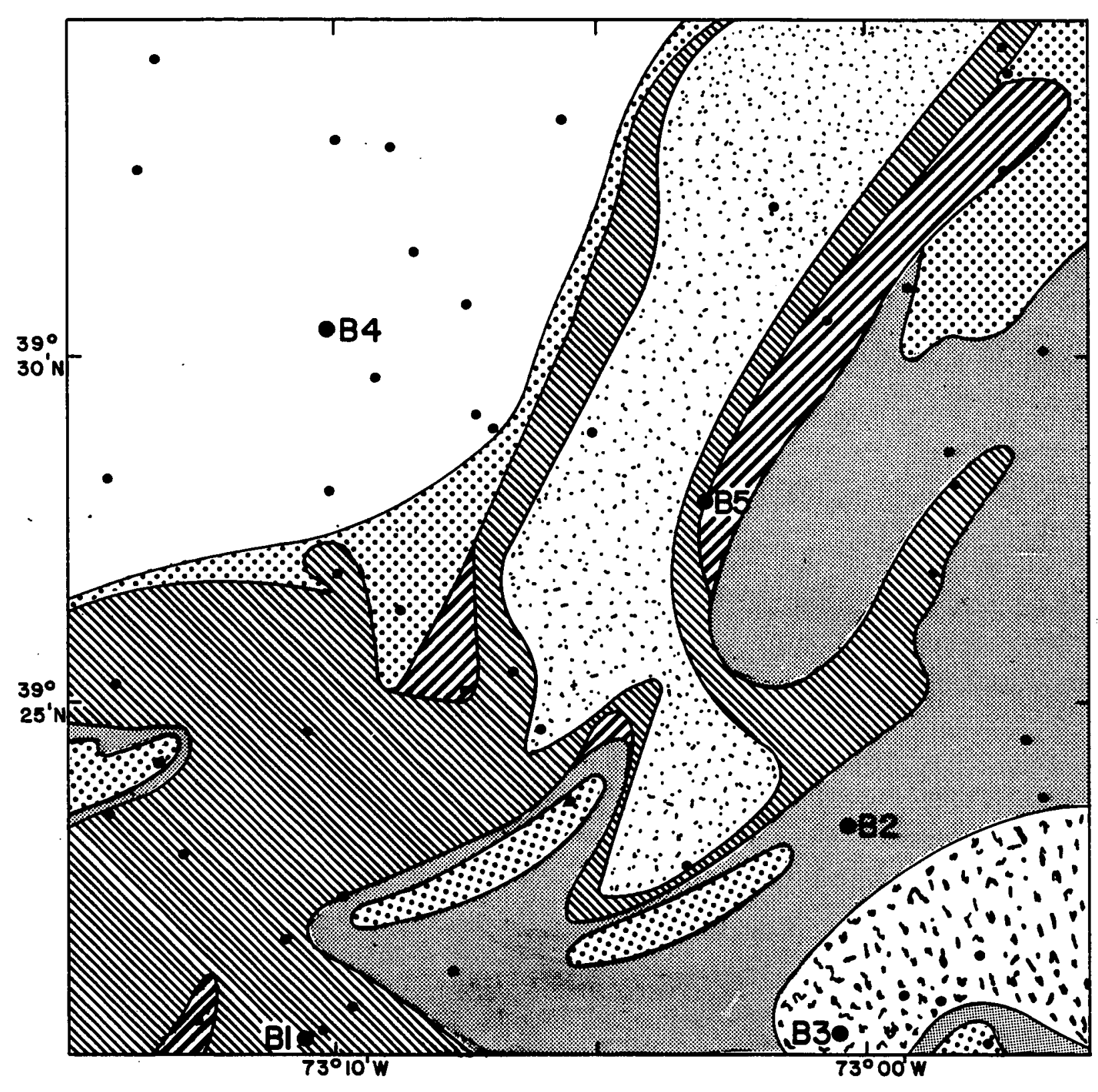

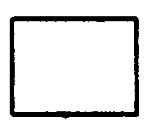

TERRACE

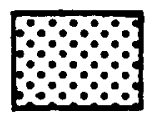

RIDOE

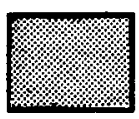

MED-SAND

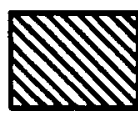

MEDD-FK

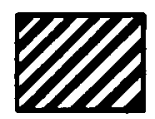

ERLDER

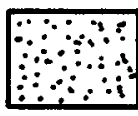

SHALLON

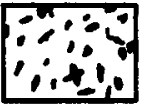

DEEP
SWALE 


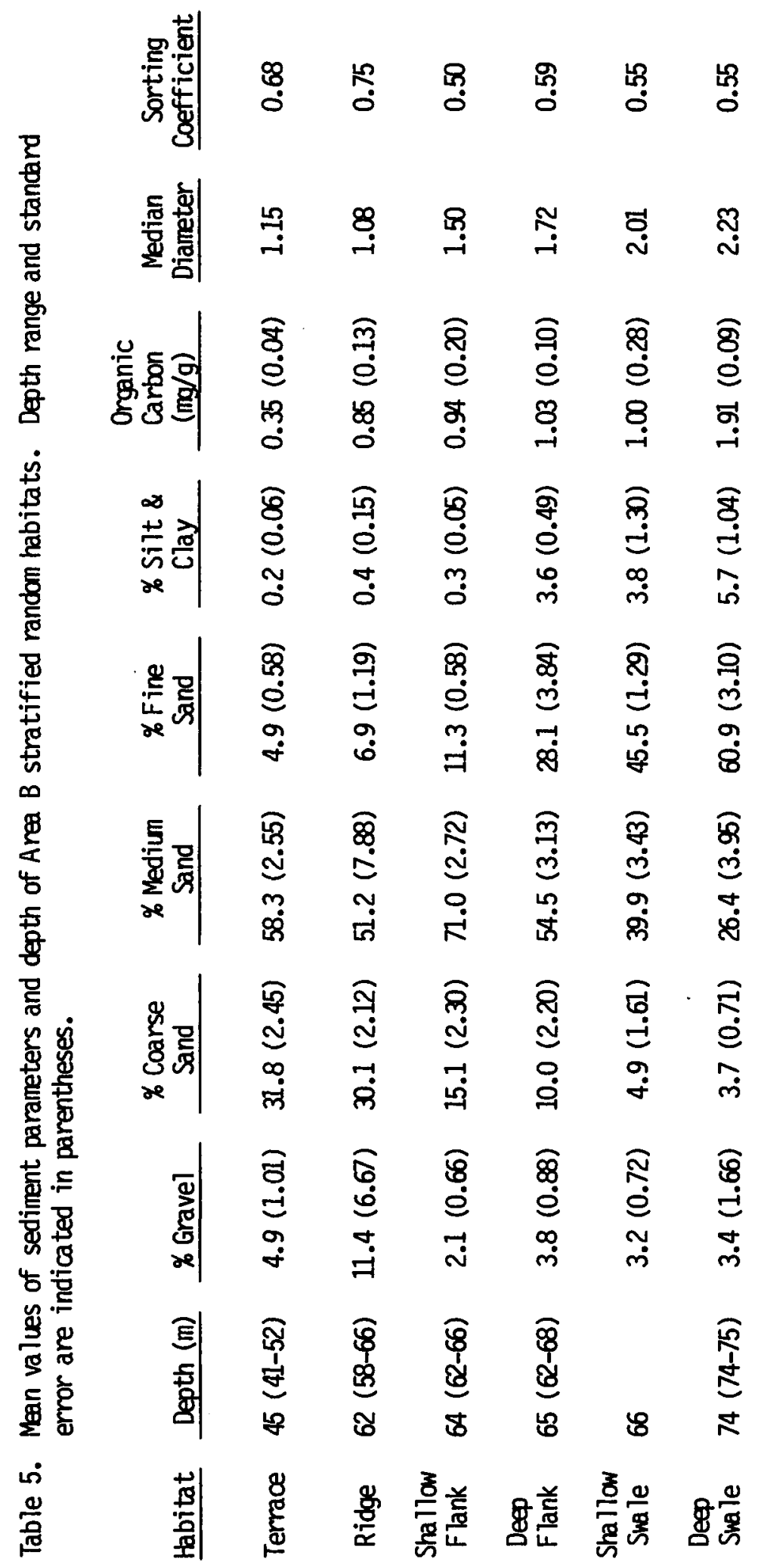


As with the broad scale analyses, numerical classification was conducted on the abundance and distribution data of polychaetes collected in Area B. This expected to show that many of the habitats within Area B could be distinguished using polychaetes alone, and would give credence to polychaete feeding biology patterns associated with the same habitats. Boesch (1979a) had previously shown that these habitats were distinguished by use of all macrobenthic taxa. Oniy polychaete species were here included in the cluster analysis. These included both quarterly and stratified random collections at stations within Area B. Since replicate samples were taken in the quarterly sampling, but not in the stratified random study, all collections were standardized to individuals per square meter. As with all numerical classification in this investigation, the methods included log transformed data, Bray-Curtis similarity, and flexible sorting with beta established at -0.25 . The resultant cluster of Area B stations is shown in Figure 33 and Table 6 . This analysis showed the similarity between ridge and terrace habitats. Both are areas of physically dynamic medium and medium-coarse sand which supported an abundance of polychaetes. Deep swale stations also formed a tight cluster. Intermediate habitats were less easily distinguished since they shared a similar fauna, and the communities changed gradually between them. Deep and shallow flank stations were not well distinguished in the analysis, and therefore are simply grouped under "flank" in Figure 33. Though all shallow swale stations were grouped together, they were very similar to flanks in the ana iysis. 
Figure 33. Numerical classification of Area B stations (Bray-Curtis similarity, flexible sorting, beta $=-0.25)$. 


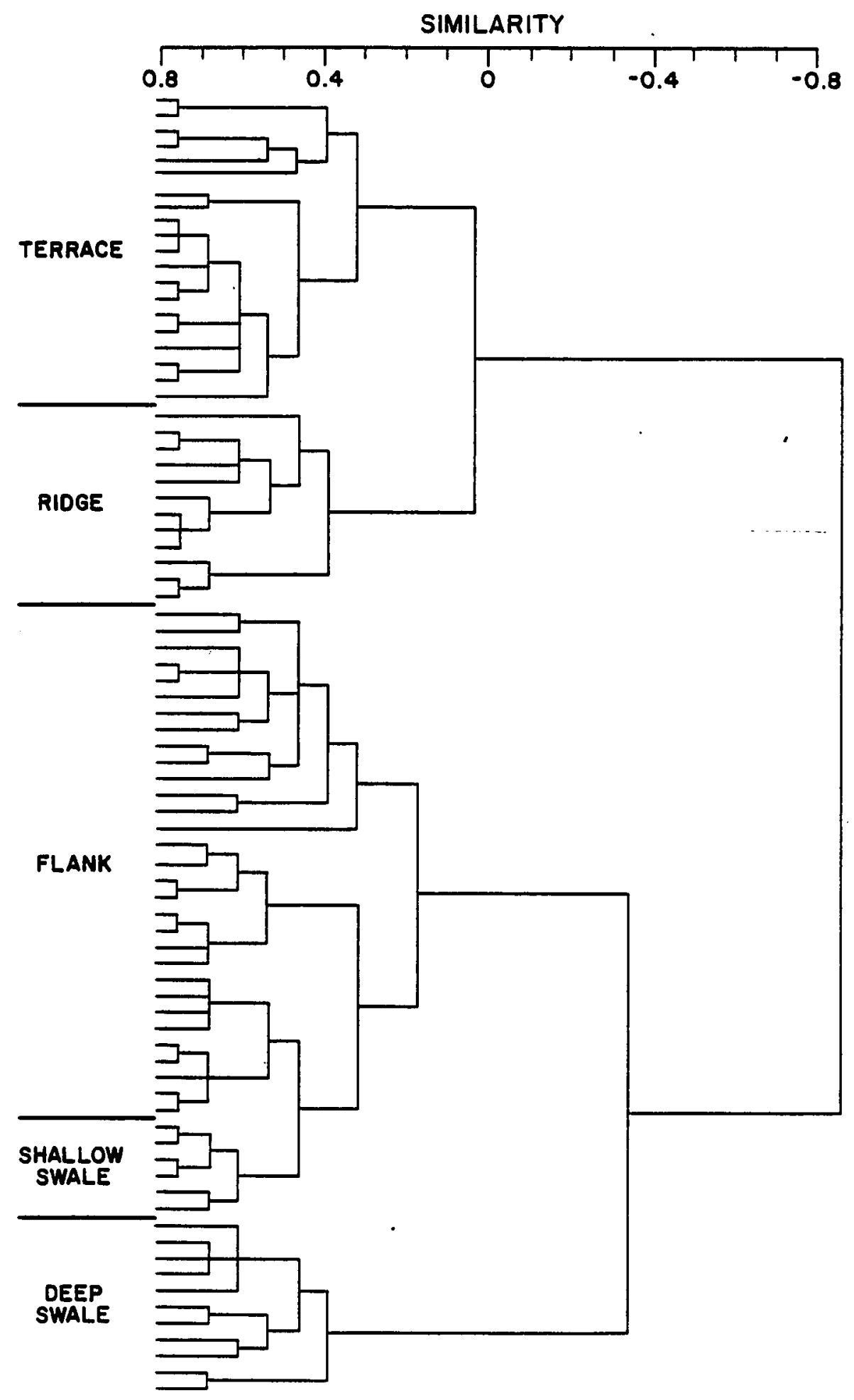


Table 6. Station groups by habitat selected from numerical classification of polychaetes collected in Area B. Hyphenated sites are quarterly cruise stations. 0 thers are stratified random stations described by Boesch (1979a, 1979b).

\begin{tabular}{|c|c|c|c|c|}
\hline Terrace & $\underline{\text { Ridge }}$ & Flank & $\begin{array}{c}\text { Sha llow } \\
\text { Swa le } \\
\end{array}$ & $\begin{array}{r}\text { Deep } \\
\text { Swale } \\
\end{array}$ \\
\hline $\begin{array}{l}\text { B4-1 } \\
\text { B4-2 } \\
\text { B4-3 } \\
\text { B4-4 } \\
\text { B4-5 } \\
\text { B4-6 } \\
\text { B4-7 } \\
\text { B4-8 } \\
\text { BF 1 } \\
\text { BF 2 } \\
\text { BP0 } \\
\text { BP1 } \\
\text { BP2 } \\
\text { BP3 } \\
\text { BP4 } \\
\text { BP5 } \\
\text { BP6 } \\
\text { BP7 } \\
\text { BP8 } \\
\text { BP9 }\end{array}$ & $\begin{array}{l}\text { B2-1 } \\
\text { B2-2 } \\
\text { B2-3 } \\
\text { B2-4 } \\
\text { B2-5 } \\
\text { B2-6 } \\
\text { B2-7 } \\
\text { B2-8 } \\
\text { BF } 3 \\
\text { BR2 } \\
\text { BR4 } \\
\text { BR5 }\end{array}$ & $\begin{array}{l}\text { B1-1 } \\
\text { B1-2 } \\
\text { B1-3 } \\
\text { B1-4 } \\
\text { B1-5 } \\
\text { B1-6 } \\
\text { B1-7 } \\
\text { B1-8 } \\
\text { B5-5 } \\
\text { BD1 } \\
\text { BD2 } \\
\text { BD3 } \\
\text { BD4 } \\
\text { BD5 } \\
\text { BF4 } \\
\text { BF5 } \\
\text { BF 6 } \\
\text { BM1 } \\
\text { BM2 } \\
\text { BM3 } \\
\text { BM4 } \\
\text { BM5 } \\
\text { BM6 } \\
\text { BR6 } \\
\text { BR7 } \\
\text { BR8 } \\
\text { BR9 } \\
\text { BS0 } \\
\text { BS4 } \\
\text { BS5 } \\
\text { BS7 }\end{array}$ & $\begin{array}{l}\text { B5-6 } \\
\text { B5-7 } \\
\text { B5-9 } \\
\text { BR3 } \\
\text { BS1 } \\
\text { BS3 } \\
\text { BS6 }\end{array}$ & $\begin{array}{l}\text { B3-1 } \\
\text { B3-2 } \\
\text { B3-3 } \\
\text { B3-4 } \\
\text { B3-5 } \\
\text { B3-6 } \\
\text { B3-7 } \\
\text { B3-8 } \\
\text { BD6 } \\
\text { BS8 } \\
\text { BS9 }\end{array}$ \\
\hline
\end{tabular}


The proportions of the feeding biology components are presented in Table 7 by habitat. Percentage values in the table are average percentages of collections rather than percentage of the total individuals collected, and include both stratified random and quarterly cruises in Area B.

Proportions of the three detritivore components were hypothesized to be associated with sediment variables, and therefore vary between habitats. Table 7 indicates an increase in proportion of subsurface deposit feeders (B) from the terrace (20\%) to the deep swale (52\%) which was positively correlated $(r=0.850, \alpha \leq 0.05)$ with organic carbon content of the sediments. Greater proportions of surface deposit feeders $(S)$ were found in coarser sediment habitats such as terrace and ridges than were found in finer sediment habitats such as swales. The proportion of surface deposit feeders was negatively correlated with organic carbon $(r=-0.858, \alpha \leq 0.05)$ and percent fine sand $(r=-0.853, \alpha \leq 0.05)$ from terraces to deep swales.

Carnivorous polychaetes (C) were predicted to be in greatest proportion in coarse sediment habitats. Carnivores generally decreased in proportion from dynamic to more stable habitats, and were positively correlated $(r=0.926, \alpha \leq 0.01)$ with coarse sand in Area $B$ habitats. Proportion of carnivores was greatest in ridges (45\%) and least in deep flanks (12\%).

Motile polychaetes (M) numerically dominated all habitats in Area $B$ (Table 7). Proportion of motile species was greatest in ridges (82\%). There was a trend of increased relative abundance of sessile 
Table 7. Percentage of each feeding, motility and morphological classification by habitat in Area B. Percentage values are average percentages of collections in each habitat. Classifications: surface deposit feeder (S); subsurface deposit feeder (B); suspension feeder (F); carnivore (C); motile (M); discretely motile (D); sessile (L); tentaculate $(T)$; jawed $(J)$.

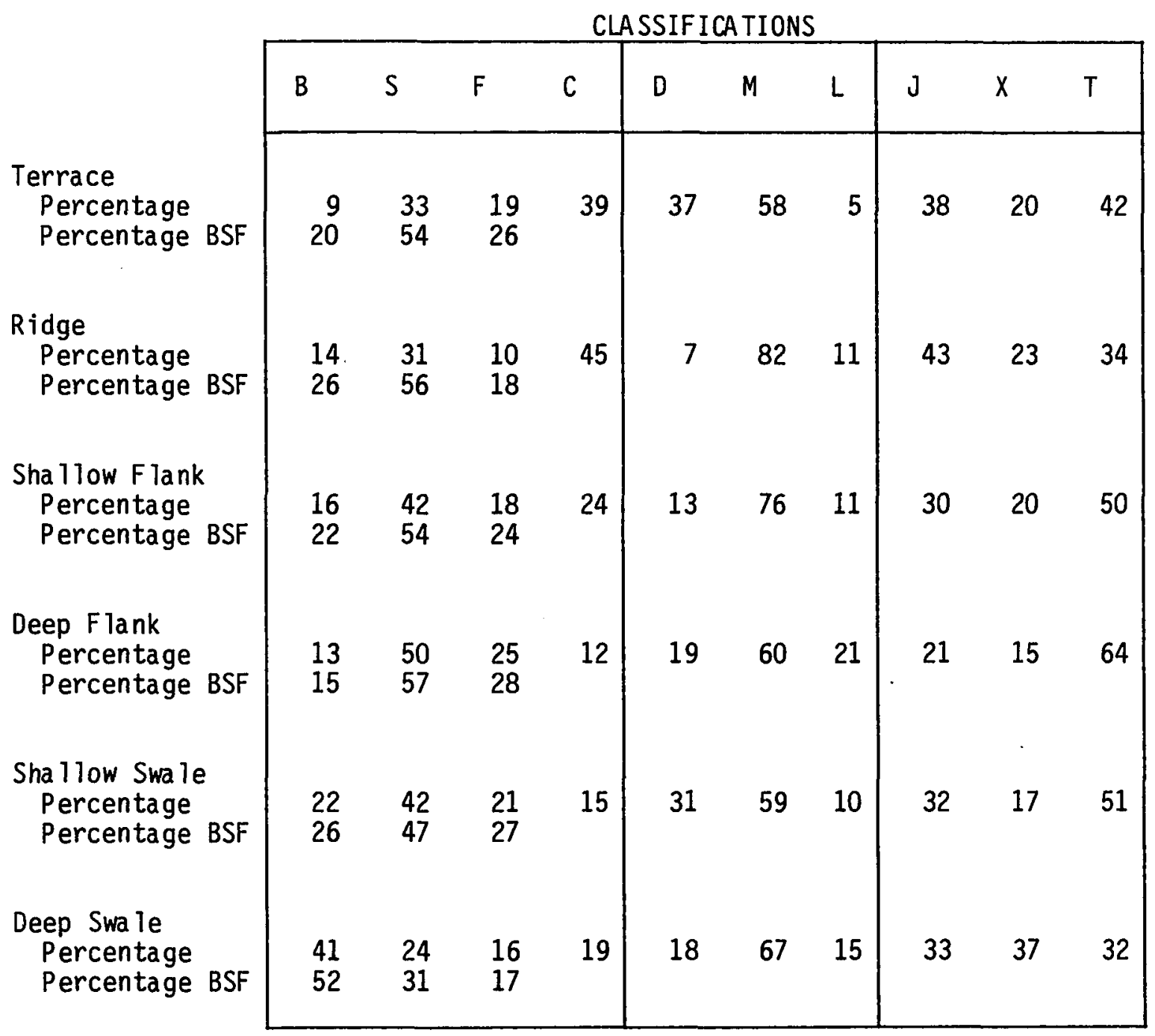


polychaetes (L) from physically dynamic habitats to more stable habitats. Sessile polychaetes were in least proportion in terraces (5\%) and greatest proportion in deep flanks (21\%). Discretely motile polychaetes (D) were in greatest proportion in the terrace (37\%) and in shallow swales (31\%). There was an increase in relative abundance of discretely motile polychaetes from ridges ( $7 \%$ ) to shallow swales (31\%) which positively correlated with percent fine sand $(r=0.986, \alpha \leq$ $0.05)$.

The proportions of each morphological component are also presented for comparison in Table 7. Jawed polychaetes $(J)$ were in greatest proportion in the most physically dynamic habitats, the terrace (38\%) and ridges (43\%), but were also well represented in the deep swales (33\%). Soft proboscis polychaetes $(X)$ were in greatest relative abundance in deep swales (37\%). Tentaculate polychaetes $(T)$ contributed the greatest proportion of polychaetes in intermediate habitats: shallow flanks (50\%); deep flanks (64\%); and shallow swales (51\%).

Figures 34 through 36 are ternary diagrams of polychaete feeding, motility, and morphology. As with broad scale pattern analyses, carnivorous and herbivorous polychaetes were excluded from the feeding diagram (Figure 34) to allow for comparison of the detritivore components. The dominant detritivores in Area $B$ were surface deposit feeders (Figure 34). Terrace stations were widely distributed due primarily to the patchy distribution of the spionid, Spiophanes bombyx. S. bombyx is an opportunistic species that is widely distributed in Area $B$ and common on the terrace. Ridges generally had fewer suspensions feeders than 
Figure 34. Ternary diagram of Area B sampling sites identified by habitat. Sites are distributed by percentage of the three components of deposit feeding polychaetes: surface, subsurface and suspension. Mean values of sites in each habitat are plotted as centroids in small diagram at right. 


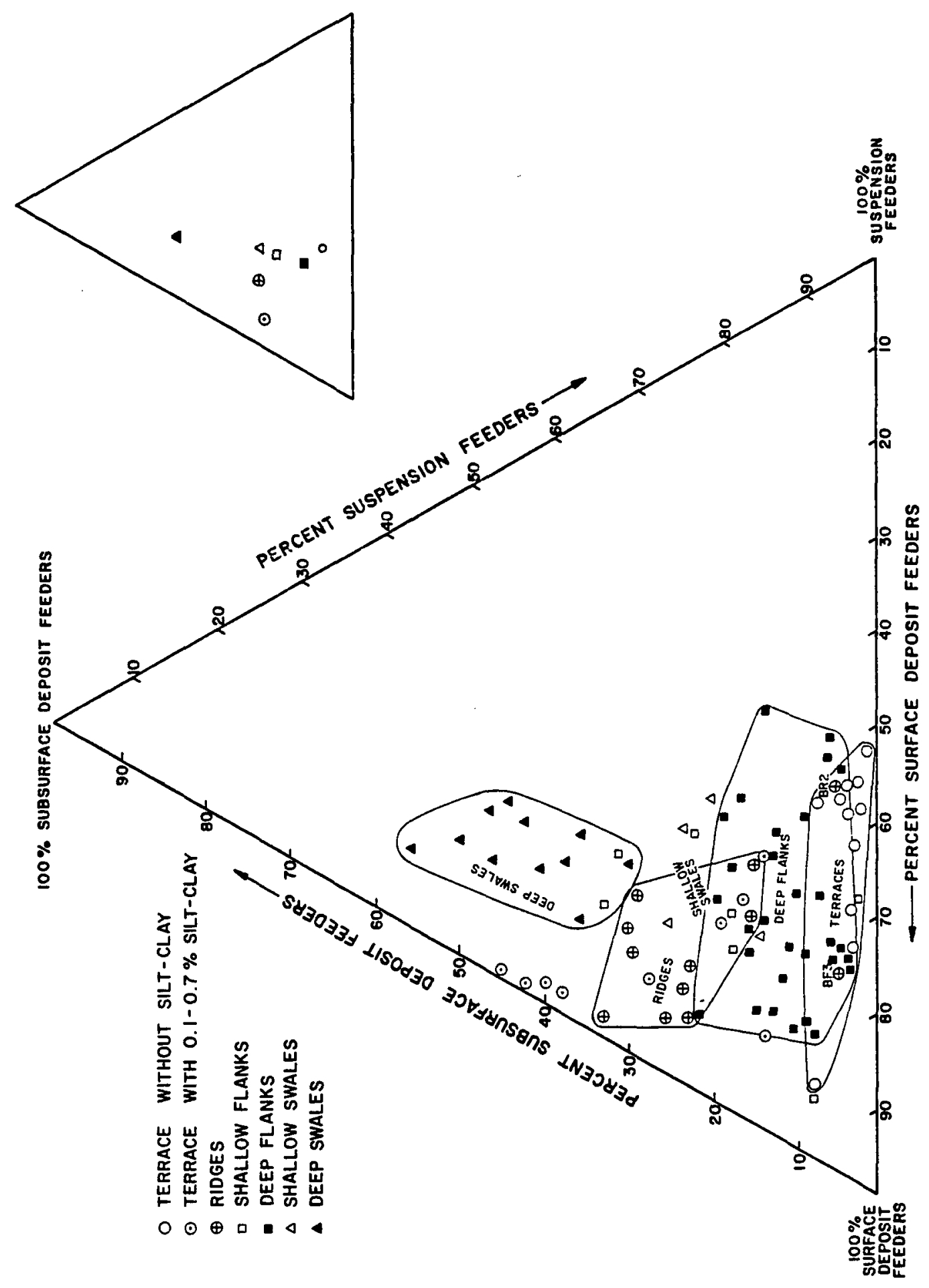


Figure 35. Ternary diagram of Area B sampling sites identified by habitat. Sites are distributed by percentage of the three components of polychaete motility: motile, discretely motile and sessile. Mean values of sites in each habitat are plotted as centroids in small diagram at right. 


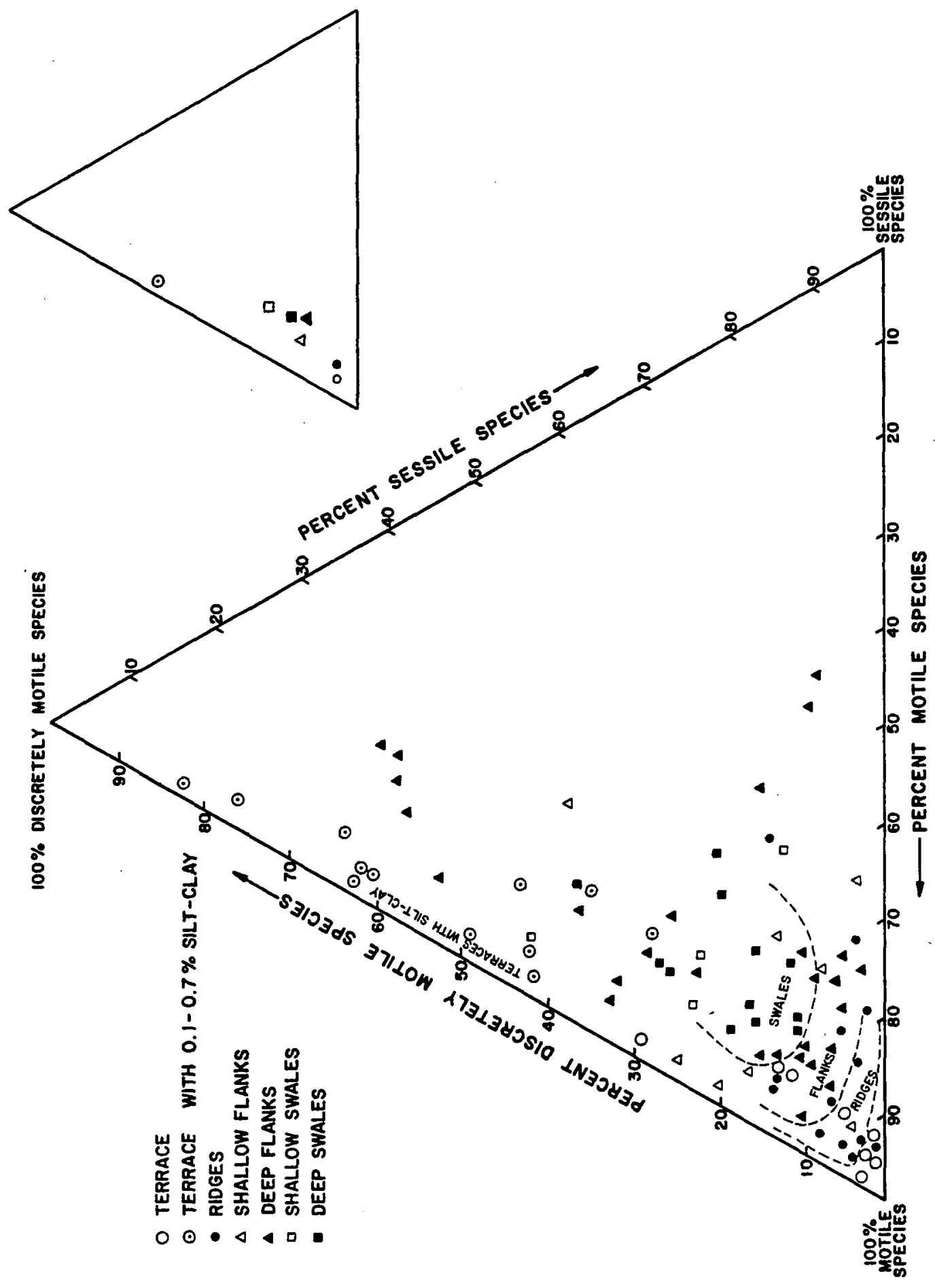


Figure 36. Ternary diagram of Area B sampling sites identified by habitat. Sites are distributed by percentage of the three primary components of polychaete morphology: jawed, tentaculate and soft proboscis. Mean values of sites in each habitat are plotted as centroids in small diagram at right. 


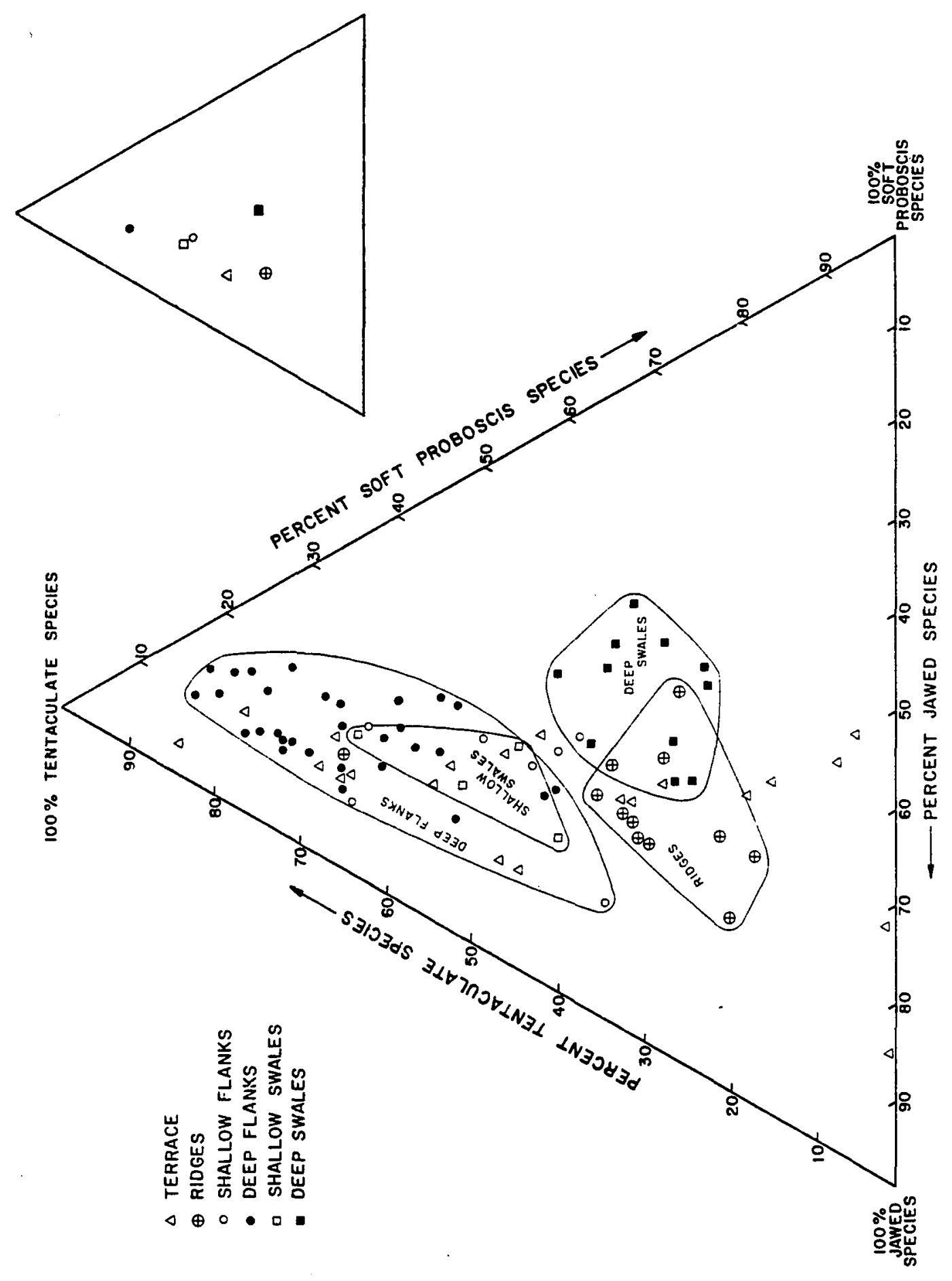


terrace stations without silt and clay, and greater proportion of subsurface deposit feeders. Deep swales had a consistent pattern of $10 \%$ to $20 \%$ suspension feeders and nearly equal numbers of subsurface and surface deposit feeders.

Figure 35 shows Area $B$ with respect to polychaete motility. Although the stations were not in well-distinguished groups, there was a trend of decreasing proportion of motile species with depth (i.e. from terrace to swales), excluding terraces with silt and clay.

The ternary diagram for polychaete morphology is Figure 36 . The terrace stations were widely distributed due to the patchy distribution of Spiophanes bombyx; however, other habitats were generally distributed in clusters which distinguished the habitats. Deep swales had approximately equal numbers of each morphological component. Ridges were similar in having nearly equal proportions of the three components, but trended toward domination by jawed polychaetes. Flank stations generally supported more tentaculate polychaetes and nearly equal numbers of jawed and soft proboscis polychaetes.

Area B Species Distributions

The physically dynamic medium-coarse sand habitats of Area B, such as the terrace and ridges, had an abundance of interstitial burrowers (e.g. Goniadella gracilis, Lumbrinerides acuta), and included diverse deposit-feeding forms (e.g. Spiophanes bombyx, Euclymene zonalis, Tharyx spp., Aricidea spp.). In the swales were higher proportions of fine sands ( $46 \%$ and $62 \%$, respectively), $4-6 \%$ silt and clay, and greater 
concentrations of organic carbon (ca. $2 \mathrm{mg} / \mathrm{g}$ in the deep swa le). These habitats supported dense populations of lumbrinerids (e.g. Lumbrineris impatiens) and capitellids (e.g. Notomastus latericeus). Each habitat in the area resembled comparable ridge field habitats in shallower zones of the shelf, but reflected the effects of greater water depth (i.e. finer sediments). For example, ridges on the inner shelf were also inhabited by abundant populations of the interstitial-feeding species, but differed in lacking abundant deposit feeders.

The most abundant surface deposit feeder on the terrace was Spiophanes bombyx. This species was joined by species of cirratulids (e.g. Caulleriella spp. and Tharyx spp.) as the dominants in ridges, flanks, and shallow swales. The paucity of surface deposit feeders in deep swales resulted from the virtual absence of $\underline{S}$. bombyx and low abundance of cirratulids. Subsurface deposit feeders were poorly represented in the more dynamic habitats (e.g. terrace, $8 \%$; ridges, 14\%), but abundant in swales (shallow swales, 24\%; deep swales, 49\%). The most abundant subsurface deposit feeders were Notomastus latericeus, Lumbrineris impatiens, and Scalibregma inflatum. Suspension feeders represented only 16 to $33 \%$ of the deposit feeders in Area B. It was the abundance of small sabellids (Euchone incolor and $\underline{E}$. elegans) that accounted for the relatively high percentages in intermediate depth habitats (e.g. shallow flanks to shallow swales). Carnivorous polychaetes were much more abundant in physically dynamic habitats than in deep flanks or swales. This resulted primarily from abundances of Lumbrinerides acuta and Goniadella gracilis. 
Most polychaetes in Area B were motile. The anomalous ratios of discretely motile:motile polychaetes on the terrace were due solely to the high abundance of $\underline{S}$. bombyx. It contributed $90 \%$ of all polychaetes collected there. In dynamic sands of ridges and shallow flanks, where $\underline{S}$. bombyx was less abundant, motile species dominated ( $87 \%$ and $77 \%$, respectively). Sessile species were rare on the terraces (only 3\%), and provided less than $25 \%$ of the fauna at any site. The most numerous sessile species were the small sabellids.

Feeding morphological characteristics of polychaetes in Area $B$ provided few data with which to distinguish habitats. Generally, the least dynamic habitats had approximately equal percentages of jawed, tentaculate, and soft proboscis species. Except for the terrace stations abundant in $\underline{S}$. bombyx, the dynamic habitats were dominated by jawed species. Intermediate areas (flanks and shallow swales) were more abundant in tentaculate polychaetes such as cirratulids and sabel1ids. Deep swales had a greater proportion of soft proboscis polychaetes (e.g. capitellids and scalibregmids):

\section{Area E Feeding Biology}

Area $E$ includes deep ridge and swa le topography (60 to $80 \mathrm{~m}$ depth) and a portion of shelf break habitat as defined in the broad scale analysis. The habitats and sampling sites are shown in Figure 37 . Like Area $B$, Area $E$ was sampled both quarterly and during the stratified random study. Sediment parameter data are provided in Table 8. Sediments in the area graded from coarse-skewed medium sand on ridge 
Figure 37. Distribution of major habitats in Area E. Quarterly and stratified random sampling sites are identified by points (redrawn from Boesch 1979a). 

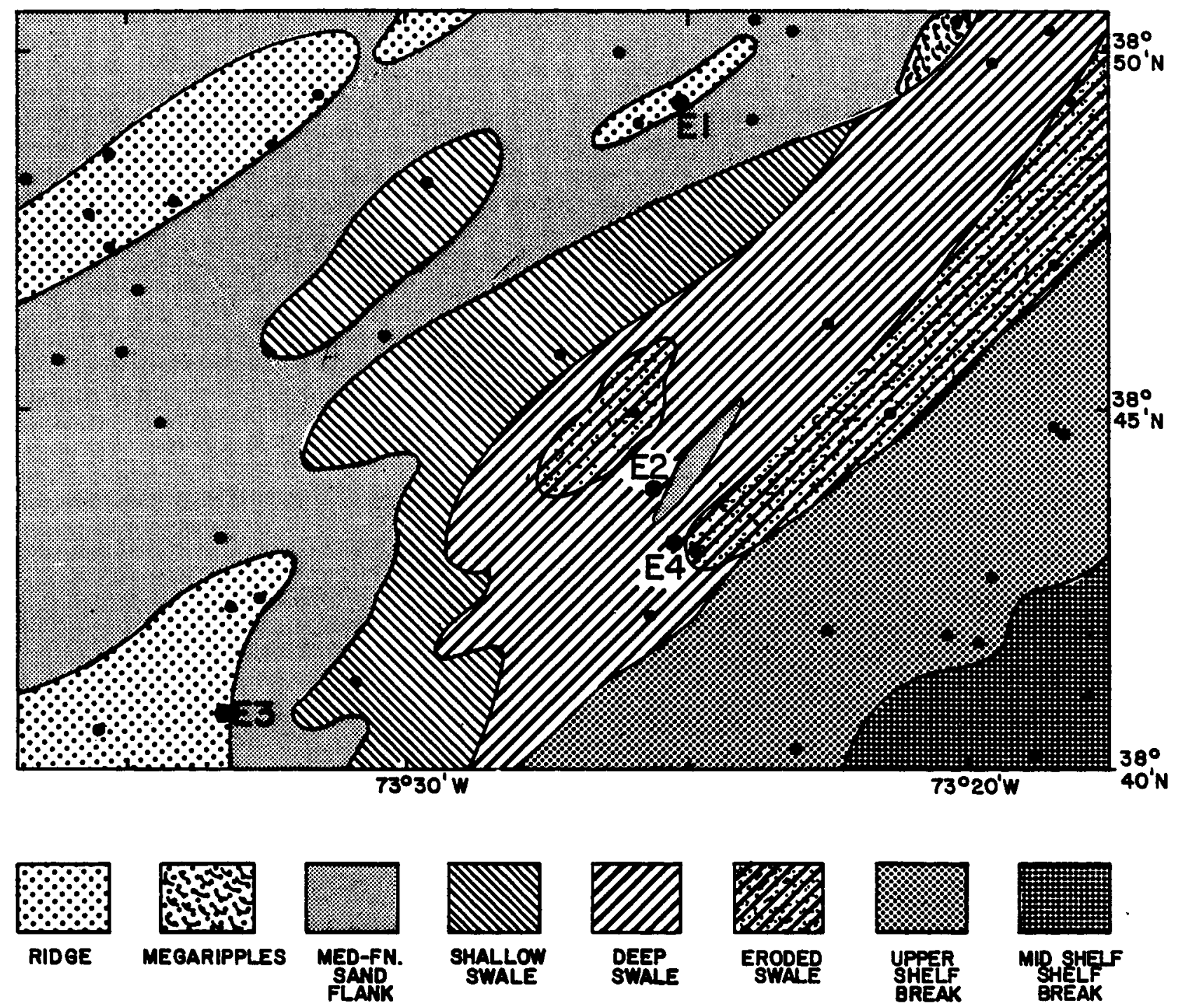


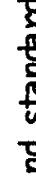

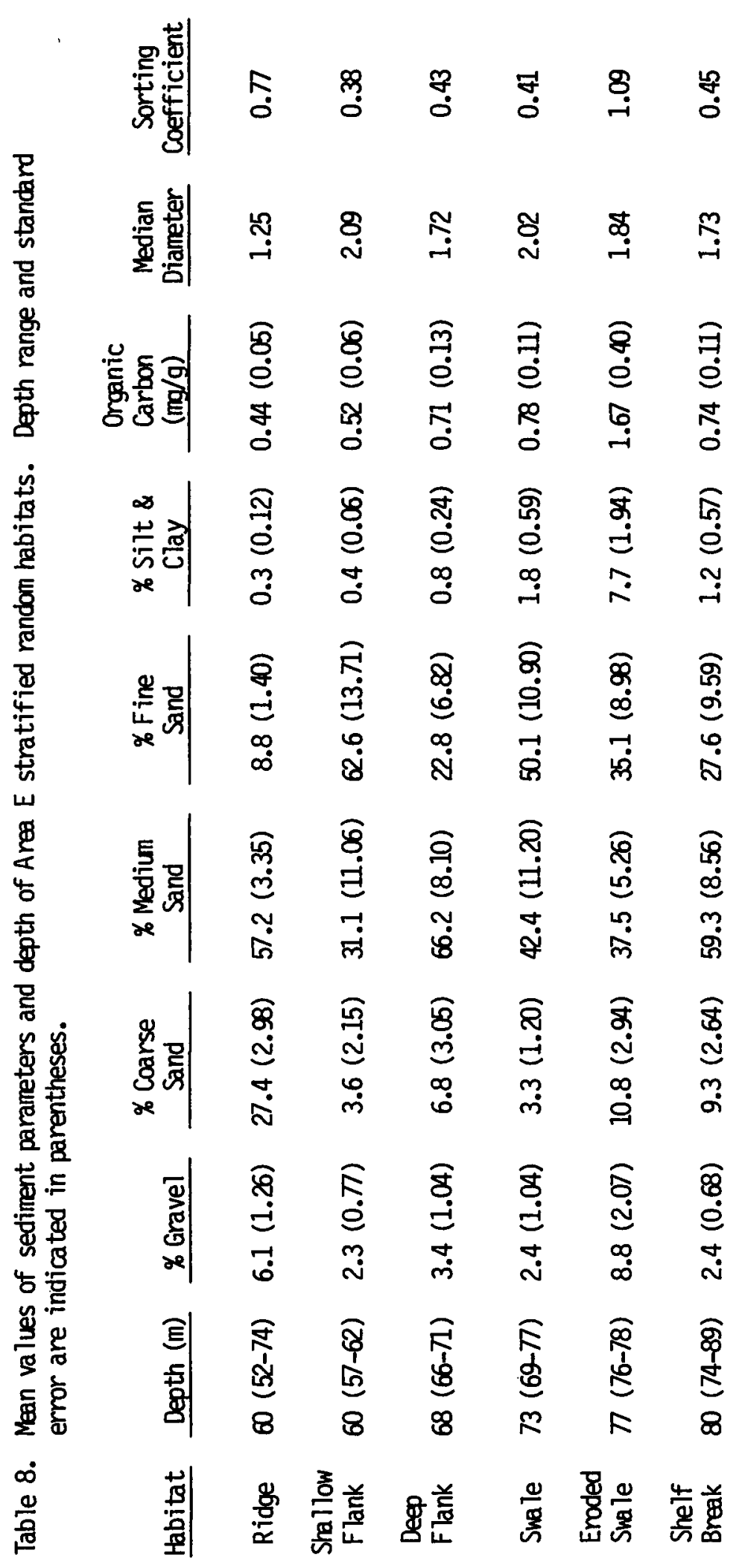


crests to fine-skewed medium and fine sand in swa les. Eroded swales had more heterogeneous sediments than shallow swales, including shell rubble and shell hash. The upper shelf break had clean, well-sorted medium sand. Below $80 \mathrm{~m}$ sediments graded to muddy, fine sands.

Results of numerical classification which was conducted on the abundance and distribution data of polychaetes collected in Area $E$ are presented in Figure 38 and Table 9. Methods were the same as those used for Area B. The results were expected to be similar to the cluster analysis conducted on Area B data in that habitats would be distinguished. There were three major habitat groups in the Area $E$ cluster: ridge; flank; and swale-shelf break. Within the latter cluster, the eroded swale stations and swale stations were distinguished from shelf break stations. As in the Area B cluster, flank stations were not clearly separated into shallow and deep habitats.

The proportions of the feeding biology components of Area $E$ are presented in Table 10 by habitat. As with Area B data, carnivores were separated in the table from detritivores. Percentage values were computed as average percentages of collections, and included both stratified random and quarterly cruises in Area $E$.

Unlike detritivore classifications for similar habitats in Area $B$, Area $E$ habitats (Table 10) were not dominated by surface deposit feeders $(S)$. There was a general trend of increasing dominance by subsurface deposit feeders (B) from ridge to eroded swales (i.e. with depth). At the break, however, subsurface deposit feeders represented only $21 \%$ of the fauna. Conversely, surface deposit feeders and suspen- 
Figure 38. Numerical classification of Area E stations

(Bray-Curtis similarity, flexible sorting, beta $=-0.25$ ). 


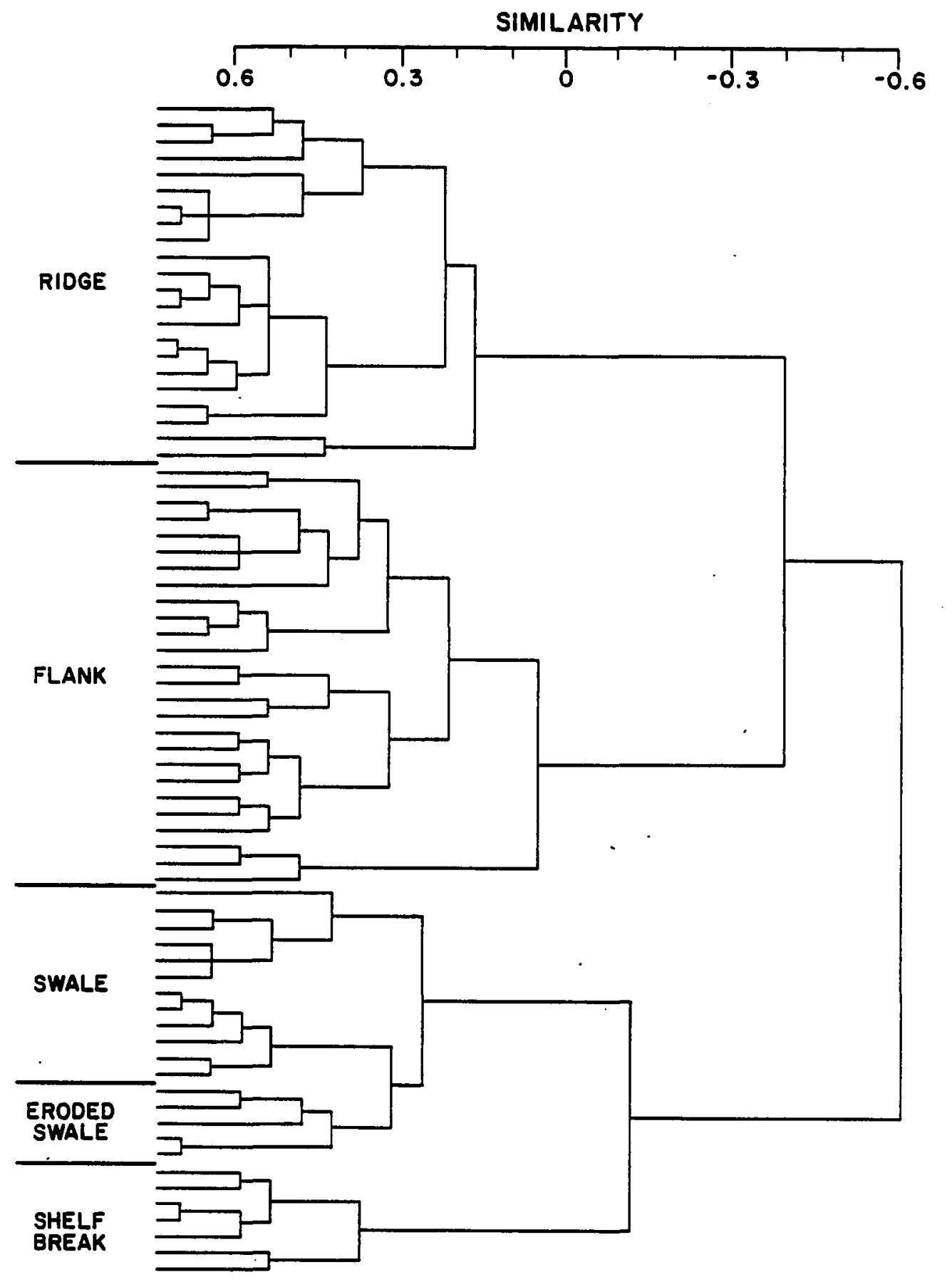


Table 9. Station groups by habitat selected from numerical classification of polychaetes collected in Area $E$. Hyphenated sites are quarterly cruise stations. others are stratified random stations described by Boesch (1979a, 1979b).

\begin{tabular}{|c|c|c|c|c|}
\hline Ridge & Flank & Swa le & $\begin{array}{l}\text { Eroded } \\
\text { Swa le } \\
\end{array}$ & $\begin{array}{l}\text { Shelf } \\
\text { Break }\end{array}$ \\
\hline $\begin{array}{l}\text { E1-1 } \\
\text { E1-2 } \\
\text { E1-3 } \\
\text { E1-4 } \\
\text { E1-5 } \\
\text { E1-6 } \\
\text { E1-7 } \\
\text { E1-8 } \\
\text { E3-3 } \\
\text { E3-4 } \\
\text { E3-6 } \\
\text { E3-7 } \\
\text { E3-8 } \\
\text { ED7 } \\
\text { EF7 } \\
\text { EF8 } \\
\text { ER1 } \\
\text { ER2 } \\
\text { ER3 } \\
\text { ER4 } \\
\text { ER5 } \\
\text { ER6 }\end{array}$ & $\begin{array}{l}\text { E2-1 } \\
\text { E2-2 } \\
\text { E2-3 } \\
\text { E2-4 } \\
\text { E3-1 } \\
\text { E3-2 } \\
\text { E3-5 } \\
\text { ED0 } \\
\text { ED1 } \\
\text { ED2 } \\
\text { ED3 } \\
\text { ED4 } \\
\text { ED5 } \\
\text { ED6 } \\
\text { ED9 } \\
\text { EF1 } \\
\text { EF2 } \\
\text { EF3 } \\
\text { EF4 } \\
\text { EF5 } \\
\text { EF6 } \\
\text { ER7 } \\
\text { ER8 } \\
\text { ES1 } \\
\text { ES2 }\end{array}$ & $\begin{array}{l}E 2-5 \\
\text { E2-6 } \\
\text { E2-7 } \\
\text { E2-8 } \\
\text { E4-1 } \\
\text { E4-2 } \\
\text { E4-3 } \\
\text { E4-4 } \\
\text { E4-6 } \\
\text { E4-7 } \\
\text { E4-8 } \\
\text { ES4 }\end{array}$ & $\begin{array}{l}\text { E4-5 } \\
\text { ED8 } \\
\text { ES3 } \\
\text { ES5 } \\
\text { ES6 }\end{array}$ & $\begin{array}{l}\text { EL1 } \\
\text { EL2 } \\
\text { EL3 } \\
\text { EL4 } \\
\text { EL5 } \\
\text { EL6 } \\
\text { ES7 }\end{array}$ \\
\hline
\end{tabular}


Table 10. Percentage of each feeding, motility and morphological classification by habitat in Area E. Percentage values are average percentages of collections in each habitat. Classifications: surface deposit feeder (S); subsurface deposit feeder (B); suspension feeder (F); carnivore (C); motile (M); discretely motile $(D)$; sessile $(L)$; tentaculate $(T)$; jawed $(J)$.

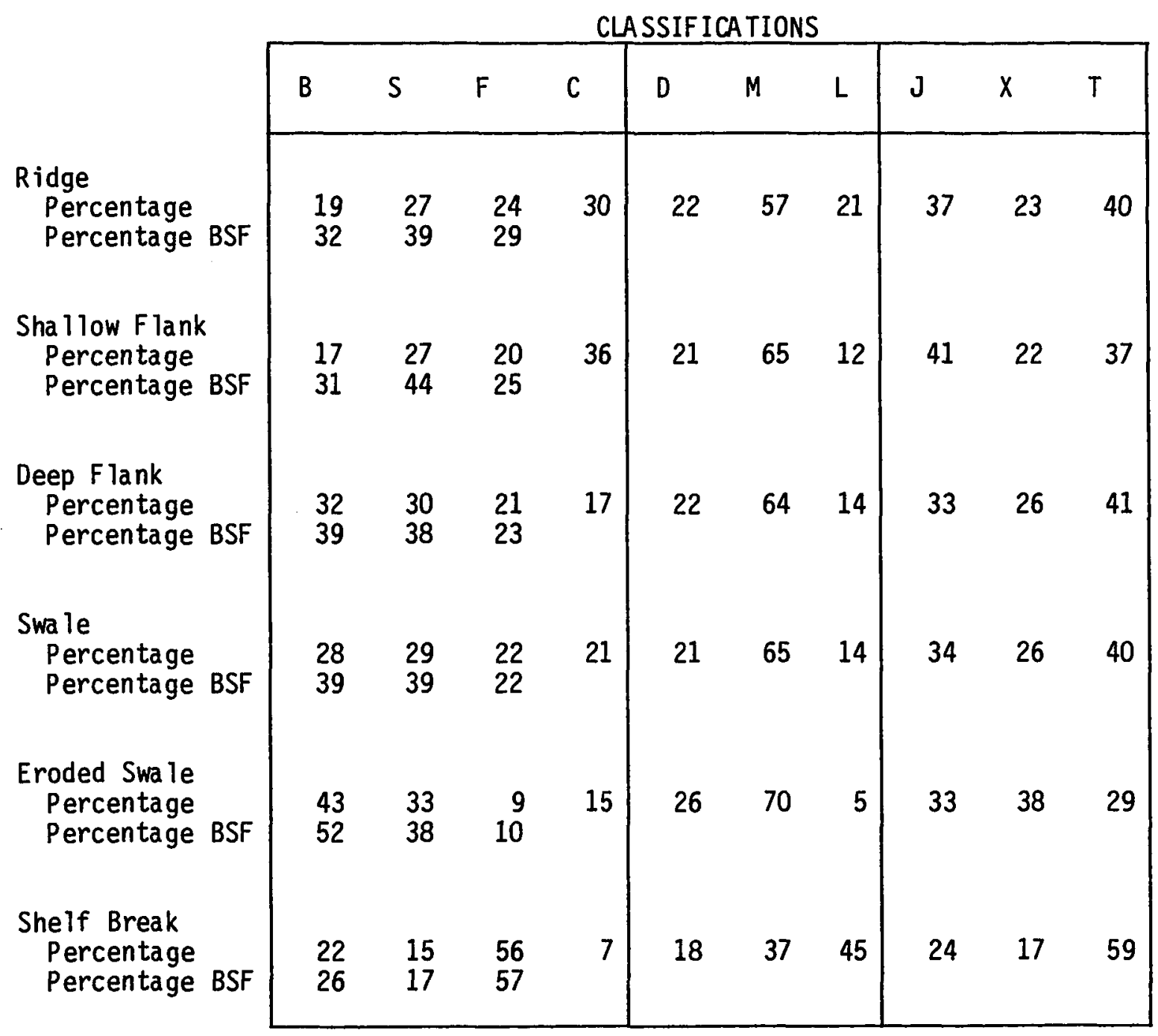


sion feeders (F) generally decreased with depth except at the shelf break where suspension feeders dominated (64\%).

Carnivores (C) were expected to be in greatest proportion in coarse sediment habitats. They dominated the polychaete fauna of ridge (30\%) and shallow flank (36\%) stations, and were least abundant at the shelf break (7\%).

Except in shelf-break habitats, Area $E$ was dominated by motile polychaetes (M). Motile species represented $70 \%$ of the polychaete fauna in eroded swales where they were in greatest proportion, and only $37 \%$ at the shelf break. Discretely motile polychaetes (D) were relatively eventy distributed between habitats. Sessile polychaetes generally decreased in proportion from ridges (21\%) to eroded swales (5\%), and numerically dominated the shelf break (45\%).

Jawed $(J)$ and tentaculate $(T)$ polychaetes dominated most habitats in Area $E$ (Table 10). Jawed species were in greatest proportion in coarse sediment habitats such as ridges and shallow flanks, and in least proportion at the shelf break. Shallow and deep flanks were distinct in having $41 \%$ and $33 \%$ jawed species, respectively. Tentaculate species represented $37 \%$ to $41 \%$ of the polychaetes in ridges, flanks, and swales, but only $29 \%$ in eroded swales. The shelf break was dominated by tentaculate polychaetes (59\%). Soft proboscis polychaetes $(X)$ were in greatest proportion in eroded swales (38\%), and least proportion at the shelf break (17\%).

Ternary diagrams of polychaete feeding biology in Area $E$ are presented in Figures 39 through 41. Distribution with respect to detriti- 
Figure 39. Ternary diagram of Area $E$ sampling sites identified by habitat. Sites are distributed by percentage of the three components of deposit feeding polychaetes: surface, subsurface and suspension. Mean values of sites in each habitat are plotted as centroids in small diagram at right. 


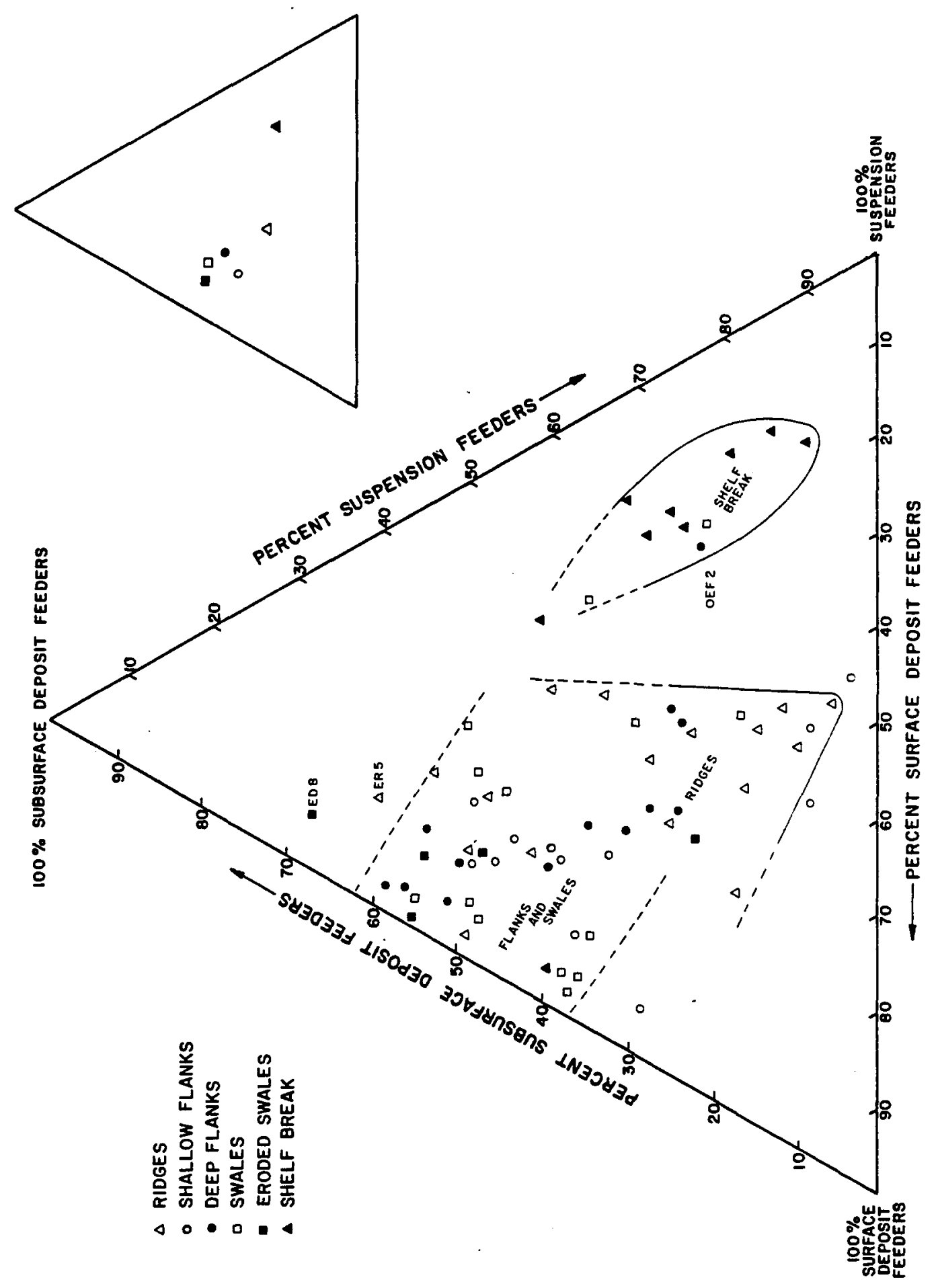


Figure 40. Ternary diagram of Area E sampling sites identified by habitat. Sites are distributed by percentage of the three components of polychaete motility: motile, discretely motile and sessile. Mean values of sites in each habitat are plotted as centroids in small diagram at right. 


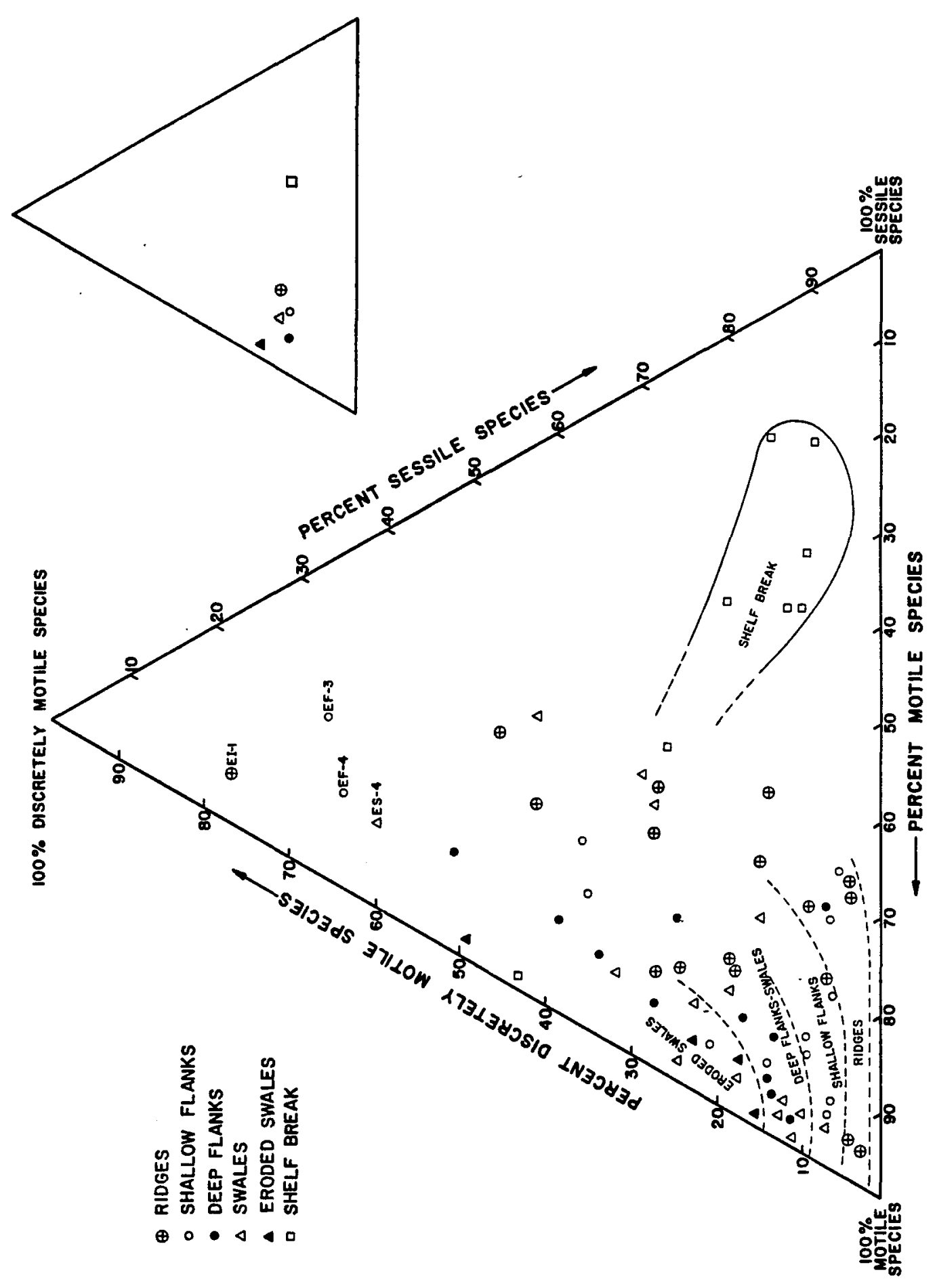


Figure 41. Ternary diagram of Area $E$ sampling sites identified by habitat. Sites are distributed by percentage of the three primary components of polychaete morphology: jawed, tentaculate and soft proboscis. Mean values of sites in each habitat are plotted as centroids in small diagram at right. 


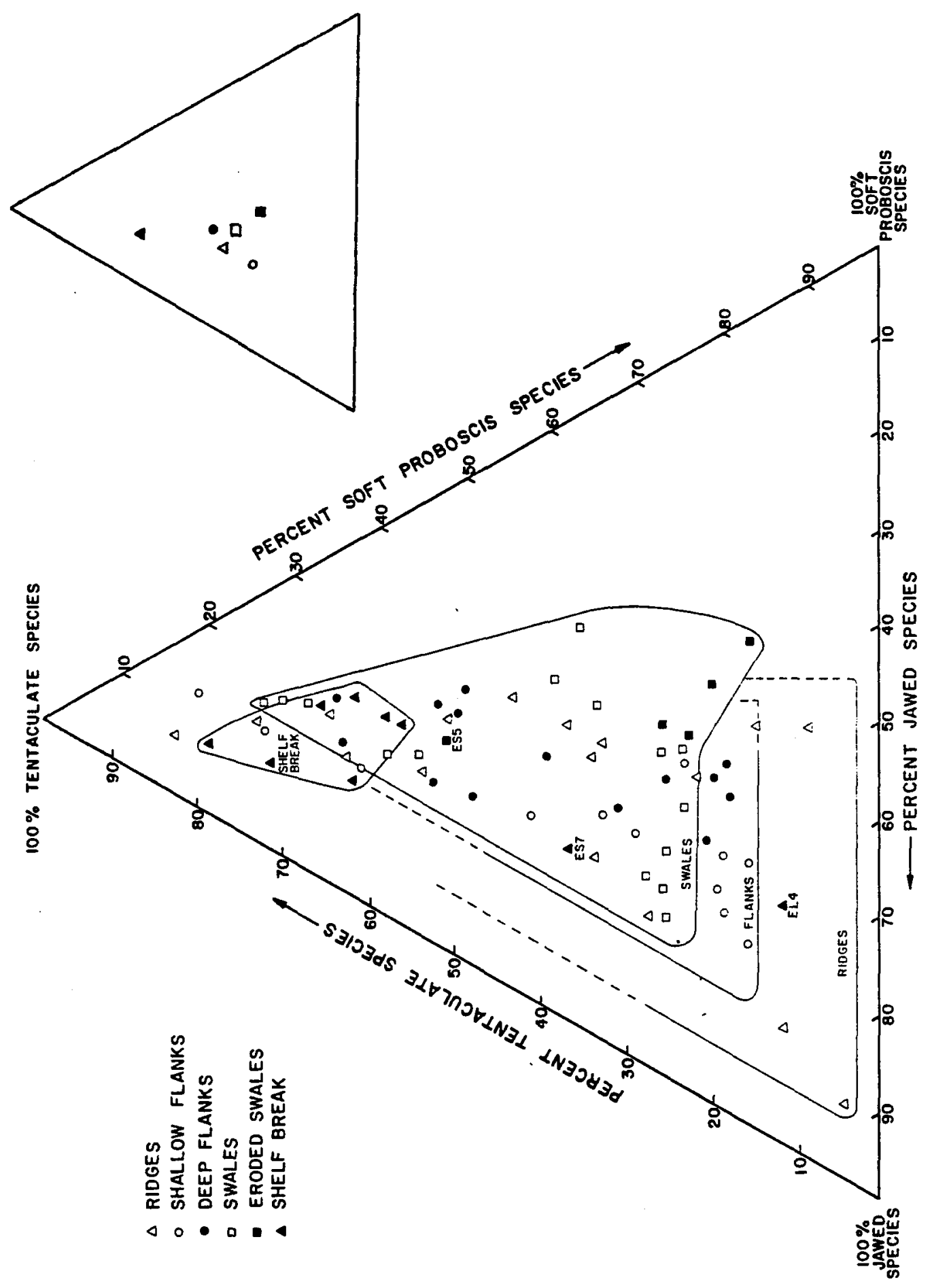


vore feeding components (Figure 39) illustrated the distinction of shelf break habitats from all others. Most shelf break stations were dominated by suspension feeders, and were inhabitated by fewer subsurface than surface deposit feeders. The shelf break stations, and the two swale and deep flank stations within the shelf break distribution area of Figure 39, were dominated by sabellids. Eroded swa le stations were generally dominated by subsurface deposit feeders, mostly lumbrinerids and capitellids. Flanks and swa les generally had equal numbers of surface and subsurface deposit feeders, and few suspension feeders.

Figure 40 illustrates the distribution of stations with respect to motility. Except for the shelf break sites which had many sessile polychaetes, no clear patterns of motility distinguished the habitats. There was, however, a general trend of fewer sessile polychaetes from ridges to eroded swa les.

The primary morphological components are presented for comparison in Figure 41. Shelf break stations had more tentaculate polychaetes than most other stations due to abundance of sabellids at the shelf break. Most other habitats had roughiy equal numbers of the three components. There was a general trend of more soft proboscis polychaetes from ridges to eroded swales, and more jawed polychaetes at certain ridge stations.

\section{Area E Species Distributions}

Generally, the habitats of Area $E$ supported assemblages closely similar to comparable habitats of Area B. The upper shelf break and 
eroded swales, habitats not included in Area B, were dominated by Chone infundibuliformis and Notomastus latericeus, respectively. In deeper areas of the shelf break, Chone was not so abundant, and other polychaetes contributed heavily to the fauna: Onuphis pallidula; Lumbrineris laterilli; Notomastus latericeus; Aricidea simplex. Ridges were occupied by few subsurface deposit feeders, and an abundance of suspension feeders (e.g. Euchone incolor, Caulleriella spp., and Spiophanes bombyx). The ridge stations of Area $E$ resembled those of A rea $B$ in having comparable proportions of surface and subsurface deposit feeders, but differed in having numerous suspension feeders. Flank stations were abundant in Lumbrineris impatiens, Scalibregma inflatum (motile, subsurface deposit feeders) and Tharyx spp. (motile, surface deposit feeders). Swales generally included these species, but were occupied by additional species of motile, soft proboscis subsurface deposit feeders (e.g. Notomastus latericeus and Scoloplos acmeceps). Many of these species also occurred on the shelf break, but the abundance of Chone at the shelf break overshadowed them. Other habitats (i.e. flanks, swales) supported additional, though small, populations of sessile species: Euchone incolor, Euchone elegans, Euclymene zonalis. The abundance of discretely motile species in ridges resulted from populations of Spiophanes bombyx present at some sites.

As in Area B, morphological characters provide few data with which to distinguish habitats in Area $E$. The dominance of tentaculate species at the shelf break was due to Chone alone. In Area E ridges, 
habitats that were scarce in tentaculate species in Area $B$, several species accounted for the difference: Spiophanes bombyx, Euchone incolor, Caulleriella spp. All were present in ridges of Area B, though their abundances were relatively low. In Area $E$, they contributed over $60 \%$ of the polychaete fauna on ridges. 


\section{DISCUSSION}

This study the first application of the Jumars and Fauchald (1977) polychaete feeding biology categories in which analyses were made of gut content of species collected in the area of study. Feeding classifications used in previous investigations have relied either on existing literature (Maurer and Leathem 1981) or on existing literature supplemented with casual observations (Jumars and Fauchald 1977). The gut content analyses of this investigation led to more accurate feeding classification of the polychaetes than previously possible, and provided a more credible data base with which to test hypotheses.

Based on investigations by Jumars and Fauchald (1977), Boesch (1979a) and Maurer and Leathem (1981), I hypothesized that the feeding biology of polychaetes in the Middle Atlantic Bight was related to sediment variables, and that patterns existed in the distribution of feeding biology parameters which would distinguịsh habitats. Specifically, it was hypothesized that carnivorous polychaetes were in greatest proportion in coarser sediments. Cross-shelf analyses indicated that carnivores were in greatest proportion in coarser sediments of the Middle Atlantic Bight inner shelf, and that the proportion of carnivores to other feeding classes decreased significantly with depth. Carnivores were positively correlated with coarse sand in the outer shelf ridge field habitats of Area $B$. These results confirmed observations by Boesch (1979a) that there is a trend toward carnivory in coarser sands of the Middle Atlantic Bight. Boesch's (1979a) conclu- 
sions were based primarily on distribution of numerically dominant species of macrobenthos. He predicted that two polychaete species, Lumbrinerides acuta and Goniadella gracilis, which he found dominant in much of the inner and middle shelf and in the coarse sediment habitats of the outer shelf, were interstitial-feeding carnivores. This study confirmed Boesch's predictions of carnivory in these two species.

The correlations of proportion of carnivorous polychaetes with depth and coarse sand probably had more to do with sediment characteristics than with depth. Most specimens of carnivorous polychaetes collected in the study area were small (e.g. dorvilleids, phyllodocids, juvenile nephtyids), and their feeding was probabiy dependent to a great extent on size of the interstices of the sediments. Coarser sediments have greater pore space between sand grains. This greater space enhances abundance of interstitial or burrowing prey organisms, enhances movement of the carnivores, and enhances oxygen penetration of the sediments (Fenchel 1970). In contrast, if all else were equal, most carnivorous polychaetes in finer sediment habitats of the Middle Atlantic Bight would probably feed at the sediment surface because of limited pore space in the sediments. However, inhabitants of finersediment habitats of the study area are probably influenced by numerous other physical and biological parameters. For instance, bottom photographs indicated that many of the finer sediment habitats (e.g. topographic depressions) are covered with shell rubble, clay lumps, and other material that generally increased structural heterogeneity Boesch 1979a). This provides increased surface area and habitat suitable 
for carnivores, including those species that feed on colonial invertebrates (e.g. syllids), hunting carnivores (e.g. phyllodocids), and other surface epifaunal, and burrowing species.

Another hypothesis posed in this investigation was that subsurface deposit feeders were in greater proportion in finer sediments. The cross-shelf analyses of this investigation indicated a positive correlation of the proportion of subsurface deposit feeders with depth and a negative correlation of the proportion of surface deposit feeders with depth. Proportion of subsurface deposit feeders was positively correlated with organic carbon, and proportion of surface deposit feeders was negatively correlated with organic carbon in ridge fields of the outer shelf (A rea B). Surface deposit feeders numerically dominated most habitats, and when compared to other detritivores, were in greatest proportion in coarser sediment habitats. These are physically dynamic habitats that are periodically scoured by currents (Swift 1976), allowing little surface detritus accumulation. Boesch (1979a) proposed that deposit feeders in such coarse sediment habitats of the Middle Atlantic Bight are primarily dependent on recently sedimented plankton detritus. In light of the dominance of surface deposit feeders in coarse sediments this certainly appears to be true.

If abundance of surface deposit feeders in the Middle Atlantic Bight is dependent on recently sedimented food, then the greatest abundance of surface deposit feeders would be expected in areas of greatest plankton production. Phytoplankton biomass and productivity in the Middle Atlantic Bight generally decreases from the inner to the 
outer shelf, then sharply increases at the shelf break (Walsh et al. 1978, Malone et al. 1979). The increase at the shelf break is believed by Malone et a1. (1979) to be due to increased enrichment provided by a frontal system at the shelf break. Broad scale analysis in this study showed that abundance and proportion of surface deposit feeders in the Middle Atlantic Bight closely paralleled the pattern of phytoplankton production. Surface deposit feeders were most abundant and in greatest proportion on the inner shelf, decreased across the shelf, then increased at the shelf break.

There are two primary criteria which affect the distribution of subsurface deposit feeders: 1) the presence of ample subsurface food resources; and 2) the adequate exchange of solutes between the sediments and the overlying water column. As discussed above, most sedimented nutrients in coarse-sediment habitats of the study area probabiy are ingested at the sediment surface. Fine-sediment habitats, such as topographic depressions, are more likely to provide the subsurface food resources necessary to support subsurface deposit feeders. Generally, topographic depressions act as sediment sinks that accumulate sediment and subsequently bury detritus. Although scouring limits net accumulation, fine sediments periodically collect in swales (Swift 1976). It was not surprising, therefore, that the greatest proportion of subsurface deposit feeders in the Middle Atlantic Bight was found in finer sediment habitats (i.e. swales).

The abundance of subsurface deposit feeders in topographic depressions is also dependent on the second criterion: the adequate exchange 
of solutes between sediments and overlying water. Without this exchange, metabolites accumulate in the sediment and oxygen penetration is limited (Fenchel 1970). Recent investigations have demonstrated that tube-dwelling macrobenthos (e.g. Aller and Yingst 1978, Brenchley 1979, Aller 1980, 1982) and surface and subsurface deposit feeders (e.g. Thayer 1979, Yingst and Rhoads 1980, Hammond 1981) may have an indirect influence on the distribution of subsurface species by altering the physical and geochemical characteristics of the sediments. Additionally, biogenic reworking of sediments by burrowers and tube irrigation by tube dwellers enhance the exchange of solutes between the water column and pore water (Rhoads et al. 1978, McCaffrey et al. 1980). Thus, presence of macrobenthic organisms may increase vertical penetration of oxygen to the sediments, increase rate of transfer of nutrients into sediments, and eliminate metabolites from sediments. This effectively increases standing stocks of bacteria (Yingst and Rhoads 1980) and other microorganisms which are recognized by most investigators (e.g. Kofoed 1975, Tenore et a1. 1978) as the actual food source of deposit feeders. Therefore, except where biogenic activity in sediments is extreme or where tube dwellers are so close as to abut, the presence of populations of deposit feeders and tube dwellers improves habitat for subsurface deposit feeders. As demonstrated by Boesch (1979a), topographic depressions on the Middle Atlantic continental shelf are occupied by rich assemblages of benthic organisms. These all may contribute to the exchange of solutes between sediments and the water colum which ultimately enhances the presence of subsurface deposit feeders. 
I hypothesized that polychaete motility in the study area was associated with sediment variables, and specifically that sessile species were associated with finer sediments. Broad scale analyses indicated that proportion of sessile polychaetes positively correlated with percent silt and clay and percent organic carbon. Jumars and Fauchald (1977) proposed that sediment stability and flux of organic matter were the covariables most responsible for similar correlations of proportion of sessile polychaetes with depth. They provided an extensive discussion of the relationship between polychaetes and their environment, including influence of sediment mobility, foraging radius of species, and variations in nutritional influx. Though the bathymetric range of the Middle Atlantic Bight study area limited adequate testing of many of Jumars and Fauchald's (1977) hypotheses concerning the association of sessile species with foraging radius and sediment stability, the positive correlation of sessile polychaetes of the study area with organic carbon and silt and clay supports their contention that sessile polychaetes generally inhabit continental shelf habitats which are physically stable. Furthermore, the dominance of motile polychaetes at a 11 cross-shelf depth zones (Figure 15) in the Middle Atlantic Bight is probably indicative of the generally unstable nature of most habitats. Discretely motile polychaetes dominate some fine-sediment habitats of the inner and middle shelf off Virginia. Generally, however, surficial sediments of the study area are coarser sand-sized particles. Rapid transgression following the last glacial period left the continental 
shelf of the Middle Atlantic Bight covered by an unconsolidated surficial sand sheet (Freeland and Swift 1978). Many investigators (e.g. Duane et a1. 1972, Swift et a1. 1972, Swift 1976) have characterized the bottom currents of the shelf as both erosional and constructional in nature, because the surficial sand that composes the topographic features is believed to be regularly redistributed. This sediment movement is probably greatest on the inner shelf, but may occasionally occur at all shelf depths. Using in situ instrumentation, Butman et a 1. (1979) demonstrated that intermittent movement of bottom sediment occurred on the Middle Atlantic Bight outer continental shelf (60 to 87 $m$ depth) in response to numerous forcing mechanisms (e.g. currents, internal waves). It is not surprising, therefore, that motile species dominated all depth zones. It is likely that domination by motile species also exists in other continental shelf areas covered by physically dynamic sediments, such as the South Atlantic Bight (Florida to North Carolina).

This investigation also concerned the association of the classes of polychaete feeding morphology with sediment variables. Since most soft proboscis polychaetes in the Middle Atlantic Bight are deposit feeders, it was expected that soft proboscis polychaetes would be in greatest proportion in habitats of greatest accumulation of detritus (i.e. swales). The outer-shelf ridge and swale habitats of Area B and E were proposed as study areas to test this hypothesis. Soft proboscis species did not numerically dominate any of the habitats of these areas; however, soft proboscis polychaetes were in greatest pro- 
portion in deep swales of Area B and eroded swales of Area $E$. These were the ridge and swale habitats of greatest silt and clay content and greatest organic carbon content (Tables 5 and 8 ). Other feeding morphology components were also associated with particular habitats. Tentaculate polychaetes were most abundant in inner and middle shelf swales. In Areas $B$ and $E$ jawed polychaetes were generally associated with coarse sediment habitats (e.g. ridges, terrace) and tentaculate polychaetes were associated with intermediate habitats (e.g. ridge flanks, shallow swales). The trend toward dominance of coarse sediments by jawed polychaetes was expected, since most jawed species in Areas $B$ and $E$ were motile carnivores. The functional advantage of jawed motile carnivores in coarse-grained sediments was discussed by Fauchald and Jumars (1979). They proposed that jawed species are better adapted to ingesting variable prey sizes than nonjawed species. Furthermore, motility is adaptive for carnivory when food is scarce, but not limiting.

Based on the information collected in this study a number of predictions concerning polychaete feeding biology can be posed as general hypotheses for future testing. Subsurface deposit feeders would likely be be most important where greatest sedimentation occurs in conjunction with high water-column production. The best areas to test this might be delta regions of large river systems, such as the Mississippi or Amazon Rivers. Secondly, as stated by Jumars and Fauchald (1977), suspension feeders would likely be in greatest proportion where adequate suspended material would exist, and where intensity and frequency 
of physical disturbance would not be limiting. Such conditions would likely occur in broad estuaries such as the Chesapeake Bay and Long Island Sound. Finally, carnivorous polychaetes would likely be in greatest proportion in physically dynamic coarse sediment habitats such as beaches and tidal inlets. Greatest abundance of carnivores would be expected in those physically dynamic habitats that would support the greatest abundance of prey organisms.

Polychaetes are an integral part of macrobenthic communities. Although our knowledge of their relationships with other taxa is poor, this investigation provides insight into their feeding biology as a group and provides a base of knowledge from which to expand our research. 


\section{SUMMARY}

1. Analyses of gut content in specimens of 64 polychaete species from 20 families led to new feeding classifications for many Middle Atlantic Bight polychaetes.

2. The greatest proportion and greatest abundance of carnivorous polychaetes in the study area occurred in coarse unstable sediments. Cross-shelf analyses indicated that the proportion of carnivores decreased significantly with depth. Carnivores were positively correlated with percent coarse sand in a topographically complex area of the outer shelf.

3. Of the three detritivore components, subsurface deposit feeders were in greatest proportion in finer sediments. Proportion of subsurface deposit feeders increased significantly with depth and percent organic carbon across the continental shelf. Surface deposit feeders numerically dominated most habitats in the study area, and were in greatest proportion in coarse sediment habitats. Abundance of surface deposit feeders decreased from the inner to the outer shelf and increased sharply at the shelf break, perhaps in response to a similar pattern in water-column production. Suspension feeders were in least abundance on the inner shelf and middle slope, probably due to instability of inner sheif sediment and scarcity of suspended food resources on the middle slope. 
4. Soft proboscis polychaetes were most abundant and in greatest proportion in topographic depressions, probably in response to detritus accumulation. Jawed and tentaculate polychaetes were abundant throughout the Middle Atlantic Bight. Jawed polychaetes on the outer shelf were in greatest proportion in physically dynamic habitats. Tentaculate polychaetes were most abundant in topographic depressions (swales) of the inner and middle shelf, and ridge flanks of Areas $B$ and $E$.

5. Sessile polychaetes generally inhabited the more physically stable habitats of the continental shelf. Cross-shelf analyses indicated that the proportion of sessile polychaetes was positively correlated with percent silt and clay and percent organic carbon. Motile polychaetes numericaliy dominated most habitats, perhaps indicative of the physically dynamic processes and generally unstable nature of the study area.

6. Topographic depressions of the Middle Atlantic Bight were distinguished from surrounding habitats in the proportional importance of feeding behaviors among the polychaetes and the composition and abundance of the polychaete species. This is probably because topographic depressions act as particle sinks that accumulate food resources in otherwise nutrient-poor areas, and accumulate lag deposits which increase structural heterogeneity. The abundance 
of polychaetes in topographic depressions of the inner and middle shelf of the study area was substantially greater than that of surrounding habitats. The difference in abundance not as evident in outer shelf topographic depressions. 


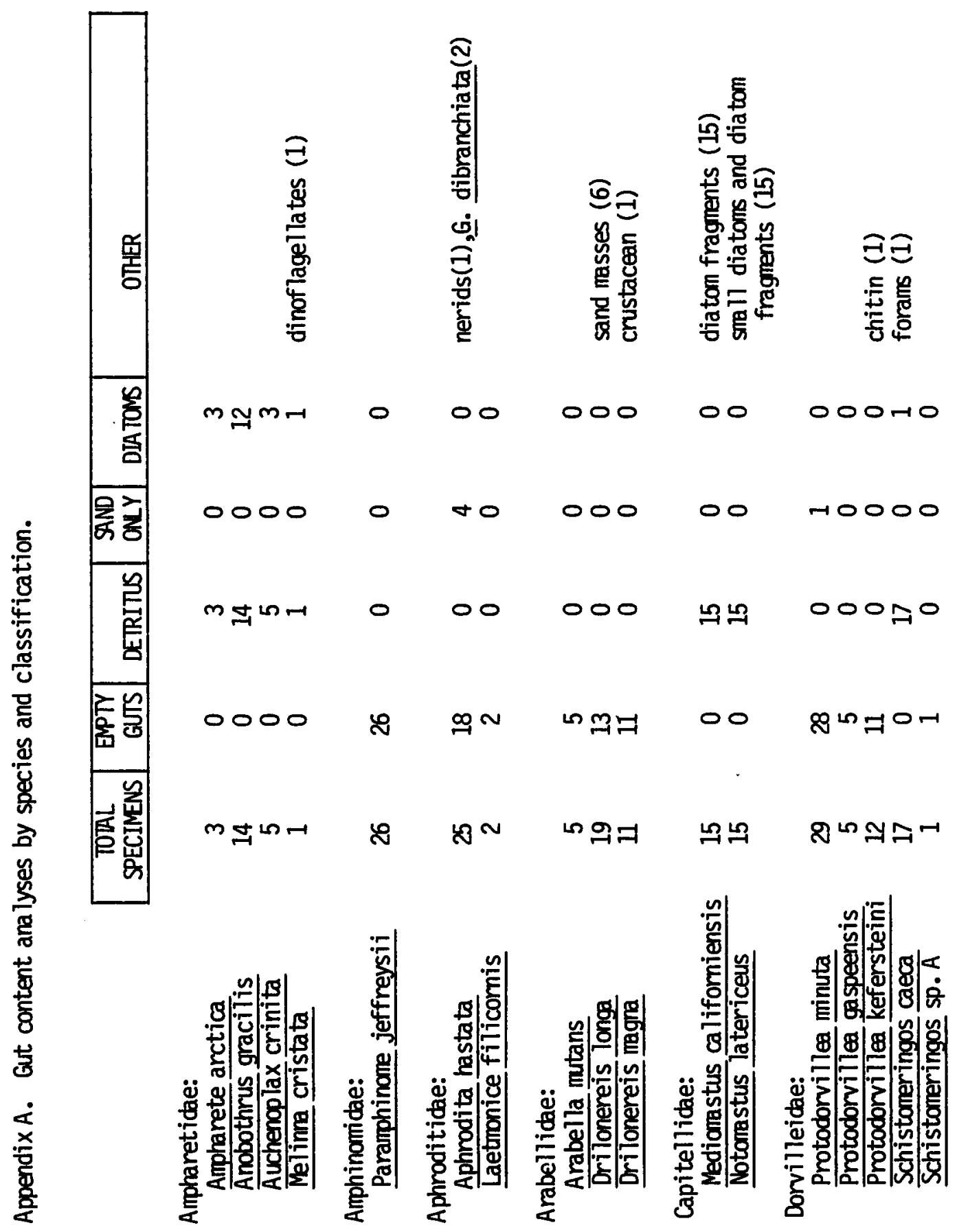




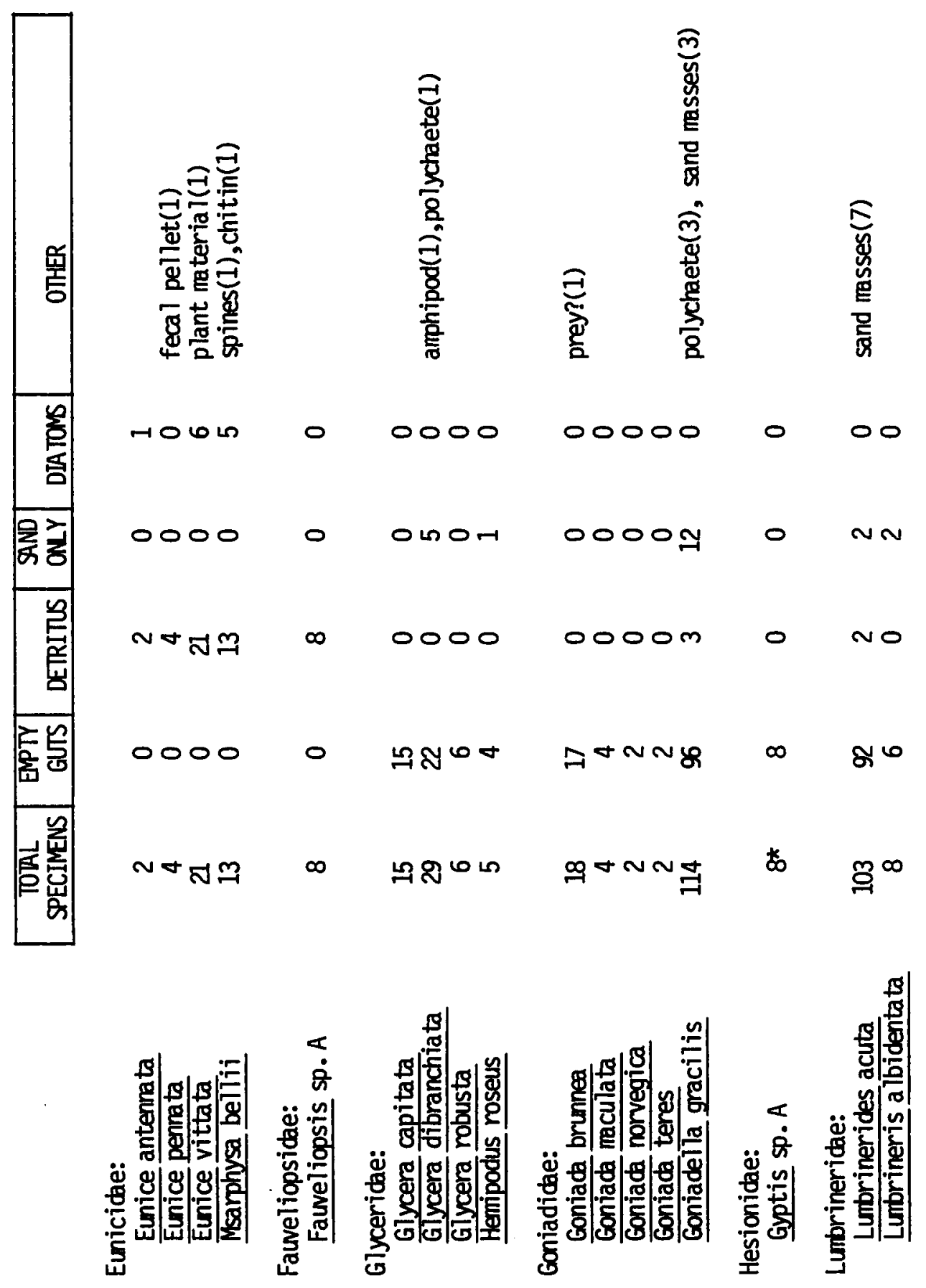




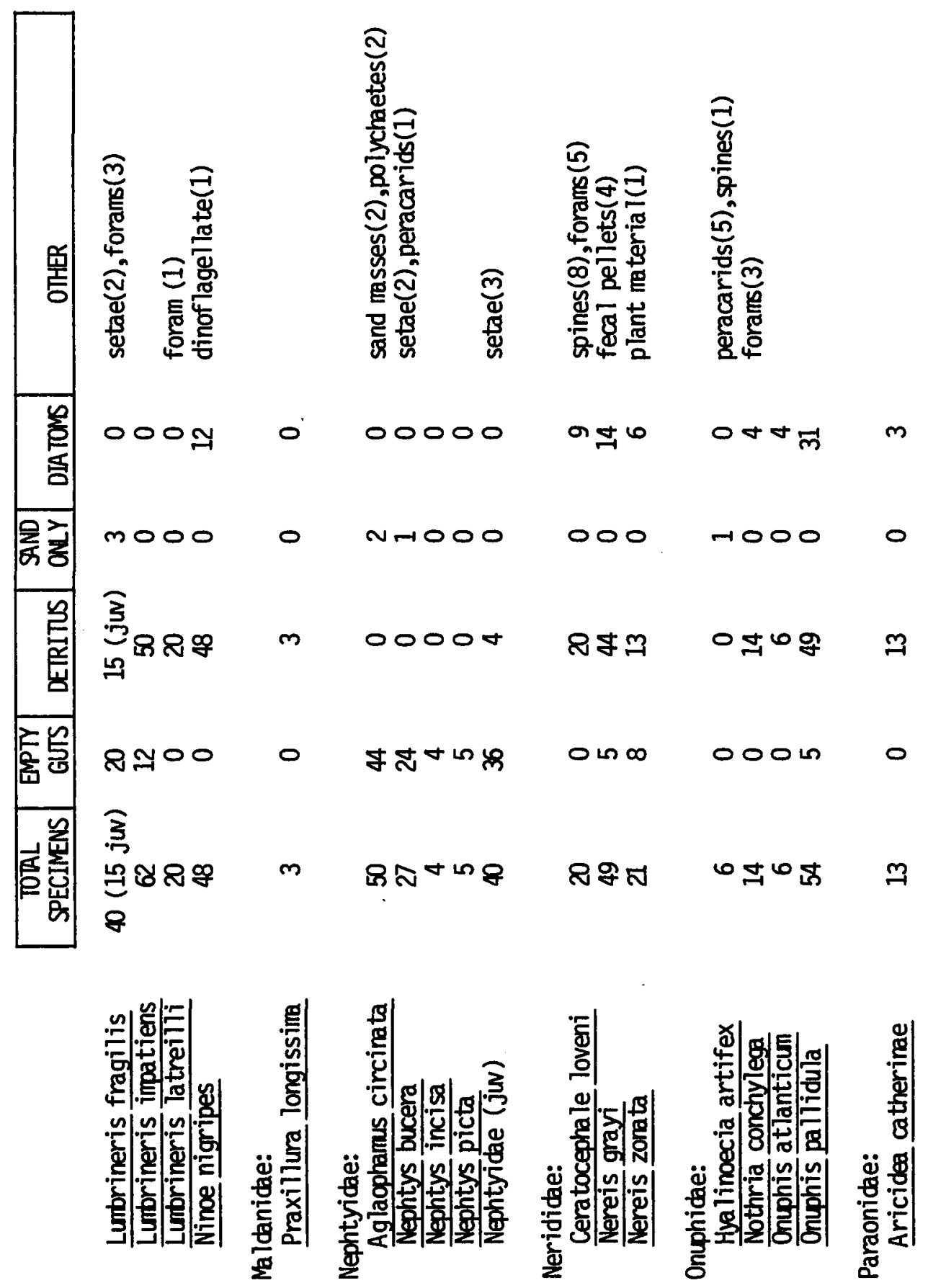




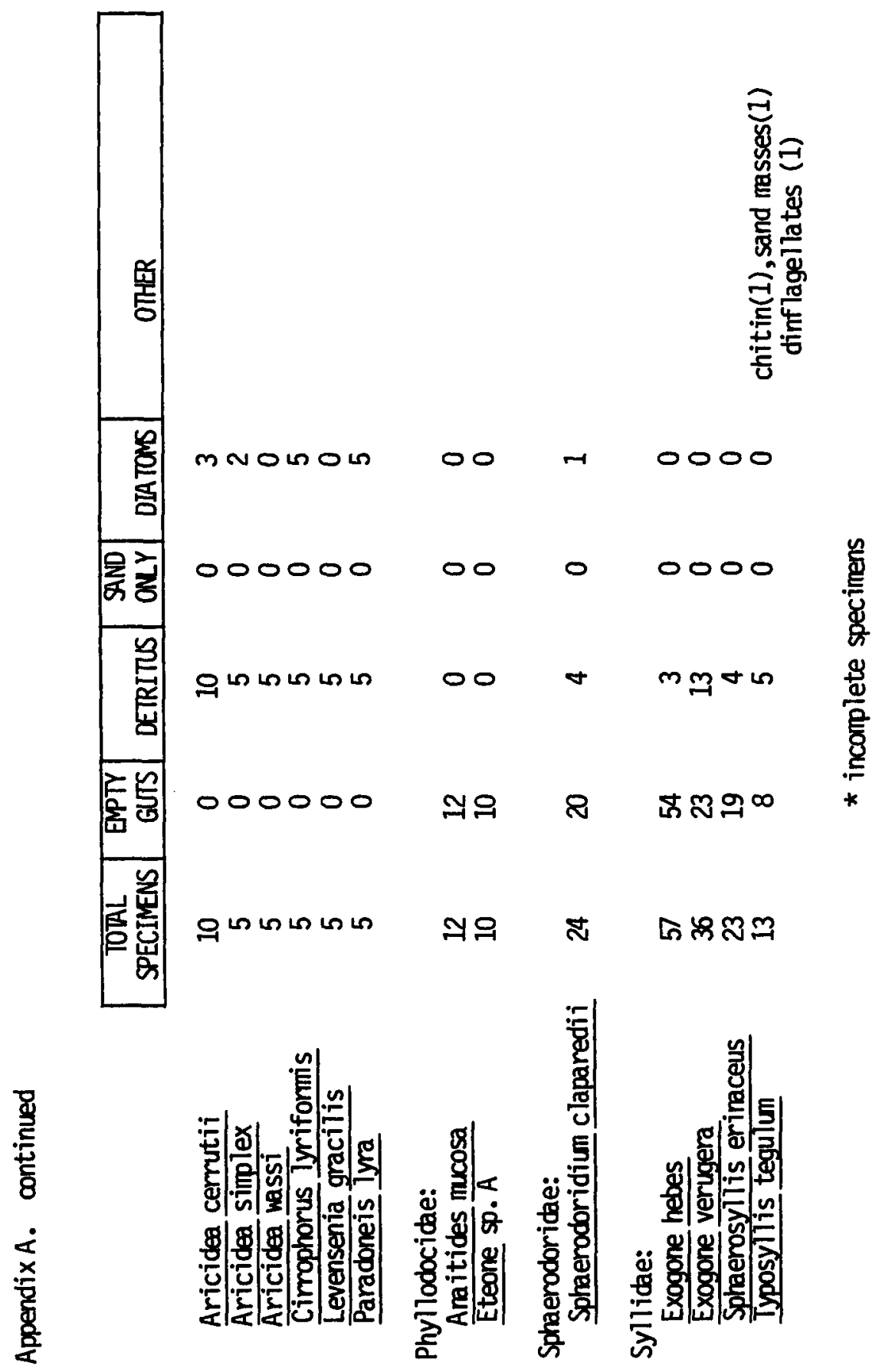




\section{BIBLIOGRAPHY}

Aller, R.C. 1978. The effects of animal-sediment interactions of geochemical processes near the sediment-water interface. Pages 157172. In: Estuarine Interactions. M. Wiley (ed.). 603 pp.

Aller, R.C. 1980. Relationships of tube-dwelling benthos with sediment and overlying water chemistry. Pages 285-308. In: Marine Benthic Dynamics. D.R. Tenore and B.C. Coull (eds.). $\overline{451}$ pp.

Aller, R.C. 1982. The effects of macrobenthos on chemical properties of marine sediment and overlying water. Chapter 2. In: AnimalSediment Relations. P.L. McCall and M.J.S. Tevesz (eds.). Plenum Publishing Corporation.

Banse, K. and K.D. Hobson. 1968. Benthic polychaetes from Puget Sound, Washington, with remarks on four other species. Proc. U.S. Natn. Mus. 125(3667). $53 \mathrm{pp}$.

Beardsley, R.C., W.C. Boicourt and D.V. Hansen. 1976. Physical oceanography of the Middle Atlantic Bight. Amer. Soc. Limnol. Oceanogr. Spec. Symp. 2:53-58.

Bell, S.S., M.C. Watzin and B.C. Coul1. 1978. Biogenic structure and its effect on the spatial heterogeneity of meiofauna in a salt marsh. J. Exp. Mar. Biol. Ecol. 35:99-107.

Biernbaum, C.K. 1979. Influence of sedimentary factors on the distribution of benthic Amphipods of Fishers Island Sound, Connecticut. J. Exp. Mar. Biol. Ecol. 38:201-223.

Blegvad, H. 1914. Food and conditions of nourishment among the communities of invertebrate animals found on or in the sea bottom in Danish water. Rep. Danish Biol. Stn. 22:41-78.

Boesch, D.F. 1979a. Benthic ecological studies: macrobenthos. In: Middle Atlantic Outer Continental Shelf Environmental Studies, Volume IIB. Chemical and Biological Benchmark Studies. Prepared by the Virginia Institute of Marine Science, Gloucester Point, VA, under Contract No. AA550-CT6-62 with the Bureau of Land Management, U.S. Department of Interior.

Boesch, D.F. 1979b. Bottom sediments and sedimentary framework. In: Middle Atlantic Outer Continental Shelf Environmental Studies, Volume IIB. Chemical and Biological Benchmark Studies. Prepared by the Virginia Institute of Marine Science, Gloucester Point, VA, under Contract No. AA550-CT6-62 with the Bureau of Land Management, U.S. Department of Interior. 
Boesch, D.F., J.N. Kraeuter, and D.K. Serafy. 1977. Distribution and structure of communities of macrobenthos on the outer continental shelf of The Middle Atlantic Bight: 1975-1976 Investigations. Chapter 6 In: Middle Atlantic Outer Continental Shelf Environmental Studies, Volume II. Chemical and Biological Benchmark Studies. Prepared by Virginia Institute of Marine Science, Gloucester Point, VA under Contract No. 08550-CT-5-42 with the Bureau of Land Management, U.S. Department of Interior. $111 \mathrm{pp} .+$ appendices.

Bray, J.R. and J.T. Curtis. 1957. An ordination of the upland forest communities of southern Wisconsin. Ecol. Monogr. 27:325-349.

Brenchley, G.A. 1979. On the regulation of marine infaunal assemblages at the morphological level: a study of the interactions between sediment stabilizers, destabilizers, and the ir sedimentary environment. Ph.D. Dissertation. Johns Hopkins University. Baltimore, MD.

Butman, B. and M. Noble. 1979. Bottom currents and bottom sediment mobility in the offshore Middle Atlantic Bight, 1976-1977. In: Middle Atlantic Outer Continental Shelf Environmental Studies, Volume III. Geological Studies. Prepared by U.S. Geological Survey, Woods Hole, MA, under Contract no. AA550-MU7-31 with the Burea $u$ of Land Management, U.S. Deaprtment of Interior.

Butman, B., M. Noble, and D.W. Folger. 1979. Long-term observations of bottom current and bottom sediment movement on the Mid-Atlantic Continental Shelf. J. Geophysical Res. 84(C3):1187-1205.

Cammen, L.M., P.A. Rublee, and J.E. Hobbie. 1978. The significance of microbial carbon in the nutrition of the polychaete Nereis succinea and other aquatic deposit feeders. Sea Grant publication; UNC-SG-78-12. University of North Carolina. Chapel Hill, NC.

Dales, R.P. 1963. Annelids. Hutchinson University Library Publs. London. $200 \mathrm{pp}$.

Dauer, D.M., C.A. Maybury and R.M. Ewing. 1981. Feeding behavior and general ecology of several spionid polychaetes from the Chesapeake Bay. J. Exp. Mar. Biol. Ecol. 54:21-38.

Day, J.H. 1967. A monograph on the Polychaeta of southern Africa. Part 1. Errantia. Part 2. Sedentaria. Brit. Mus. Publ. (Nat. Hist.), London 656:1-878.

Dayton, P.K. and R.R. Hessler. 1972. Role of biological disturbance in maintaining diversity in the deep sea. Deep Sea Res. 19: 199208. 
Dorsett, D.A. 1961. The behavior of Polydora ciliata. Tubebuilding and burrowing. J. Mar. Biol. Ass. U.K. 41:577-590.

Duane, D.B., M.E. Field, E.P. Meisburber, D.J. Swift and S.J. Williams. 1972. Linear shoals on the Atlantic inner continental shelf, Florida to Long Island. Pages 447-498. In: D.J.P. Swift, D.B. Duane and L.H. Pilkey (eds.). Shelf Sediment Transport: Process and Pattern. Dowden, Hutchinson and Ross, Stroudsburg, PA.

Ebbs, N.K. 1966. The coral-inhabiting polychaetes of the northern Florida reef tract. Part I. Bull. Mar. Sci. Gulf Caribb. 16(3): 485-555.

Eckman, J.E. 1979 Small-scale patterns and processes in a softsubstratum, intertidal community. J. Mar. Res. 37(3):437-457.

Emerson, R.R. 1974. A new species of polychaetous annelid (Arabellidae) parasitic in Diopatra ornata (Onuphidae) from southern California. Bull. Sth. Calif. Acad. Sci. 73(1):1-5.

Emery, K.0. and J.S. Schlee. 1963. The Atlantic continental shelf and slope, a program for study. U.S. Geological Survey Circ. 481. $11 \mathrm{pp}$.

Emery, K.0. and E. Uchupi. 1972. Western North Atlantic Ocean; topography, rocks, structure, water, life, and sediments. Amer. Assoc. Pet. Geol. Mem. 17. 532 pp.

Emson, R.H. 1977. The feeding and consequent role of Eulalia viridis (0.F. Muller) (Polychaeta) in intertidal communities. $\frac{\text { J. Mar. }}{\text { J. }}$ Biol. Ass. U.K. 57:93-96.

Evans, S.M. 1971. Behavior in polychaetes. Q. Rev. Bio1. 46:279-405.

Fauchald, K. 1970. Polychaetous annelids of the familes Eunicidae, Lumbrineridae, Iphitimidae, Arabellidae, Lysaretidae, and Dorvilleidae from western Mexico. Allan Hancock Monogr. Mar. Biol. 5:1-335.

Faucha 1d, K. and P.A. Jumars. 1979. The diet of worms: a study of polychaete feeding guilds. Oceanogr. Mar. Biol. Ann. Rev. 17:193284.

Fauvel, P. 1897. Recherches sur les Ampharetiens, Annelides polychetes sedentaires. Morphologie, anatomie, histologie, physiologie. Bul7. Sci. France et Belg. 30:277-488.

Fenche1, T. 1970. Studies on the decomposition of organic detritus derived from the turtle grass Thalassia testudinum. Limnol. Oceanogr. 15(1):14-20. 
Fischer, H.B. 1980. Mixing processes on the Atlantic continental shelf, Cape Cod to Cape Hatteras. Limnol. Oceanogr. 25(1):114125 .

Freeland, G.L. and D.J.P. Swift. 1975. New York alternative dumpsite assessment-reconnaissance study of surficial sediments. 10th Int. Congr. Sedimentol., theme 10, pp. 13-19. Nice, France.

Freeland, G.L. and D.J.P. Swift. 1978. Surficial Sediments. MESA New York Bight Atlas Monograph 10, New York Sea Grant Institute, A lbany, New York. 93 pp.

Goerke, H. 1966. Nahrungsfiltration von Nereis diversicolor 0.F. Muller (Nereidae, Polychaeta). Veroff. Inst. Meeresforsch. Bremerh. 10:49-58.

Goerke, H. 1971. Die Ernahrungsweise der Nereis-Arten (Polychaeta, Nereidae) der deutschen Kusten. Veroff. Inst. Meeresforsch. Bremerh. 13:1-50.

Gordon, A.L., A.F. Amos and R.D. Gerard. 1976. New York Bight water stratificaiton - October, 1974. Amer. Soc. Limnol. Oceanogr. Spec. Symp. 2:45-57.

Hammond, L.S. 1081. Ananalysis of grain size modification in biogenic carbonate sediments by deposit-feeding holothurians and echinoids (Echinodermata). Limno1. Oceanogr. 26:898-906.

Hamond, R. 1969. On the preferred foods of some Autolytoids (Polychaeta, Syllidae). Cah. Biol. Mar. 10:439-445.

Hartman, 0. 1971. Abyssal polychaetous annelids from the Mozambique Basin off Southeast Africa, with a compendium of abyssa 1 polychaetous annelids from world-wide areas. J. Fish. Res. Bd. Can. 28(10):1407-1429.

Hartmann-Schroder, G. 1971. Annelida, Borstenwurmer, Polychaeta. Die Teirwelt Deutschlands 58. 594pp.

Hauenschild, C., A. Fischer and D.K. Hofmann. 1969. Untersuchungen am paxifischen Pololowurm Eunice viridis (Polychaeta) in Samoa. Helgolander wiss. Meeresunters. 18:254-295.

Hempelmann, F. 1931. Erste und Zweite Klasses der Vermes Polymera (Annelida). Archiannelida und Polychaeta. In: Handbuch der Zoologie. Vol 2(2), Lief. 12-13. W. KukenthaT and T. Krumbach (eds.). W. de Gruyter and Co., Berlin and Leipzig. $212 \mathrm{pp.}$

Hessle, C. 1925. Bidrag till Kannedomen om de terebellomorfa polychaeternas biologi. Ark. Zool. Stockholm 17(9):1-27. 
Hughes, R.G. 1975. The distribution of epizoites on the hydroid Nemertesia antennina (L.). J. Mar. Biol. Ass. U.K. 55:275-294.

Hunt, 0.D. 1925. The food of the bottom fauna of the Plymouth fishing grounds. J. Mar. Biol. Ass. U.K. 13(3):560-598.

Jones, M.L. 1961. A quantitative evaluation of the benthic fauna off Point Richmond, California. Univ. Calif. Publs. Z001. 67:219-320.

Jorgensen, N.O.G. 1979. Uptake of L-Valine and other amino acids by the polychaete Nereis virens. Mar. Biol. 52:45-52.

Jorgensen, N.O.G. 1980. Uptake of glycine and release of primary amines by the polychaete Nereis virens (Sars) and the mud snail Hydrobia neglecta Muus. J. Exp. Mar. Biol. Ecol. 47:281-297.

Jumars, P.A. and K. Fauchald. 1977. Between-community contrasts in successful polychaete feeding strategies. Pages 1-20. In: Ecology of Marine Benthos. B. Coull (ed.). University of South Carolina Press, Columbia, SC.

Klawe, W.L. and L.M. Dickie. 1957. Biology of the bloodworm, Glycera dibranchiata Ehlers, and its relation to the bloodworm fishery of the maritime provinces. Bull. Fish. Res. Bd. Can. No. 115. 37 pp.

Knebel, H.J. and D.W. Folger. 1976. Large sand waves on the Atlantic outer continental shelf around Wilmington Canyon, off eastern United States. Mar. Geo1. 22:M7-M15.

Knebel, H.J. and E. Spiker. 1977. Thickness and age of the surficial sand sheet, Baltimore Canyon trough area. Bull. Amer. Assoc. Pet. Geol. 61:861-871.

Kofoed, L.N. 1975. The feeding biology of Hydrobia ventros (Montagu). 1. The assimilation of different components of the food. J. Exp. Mar. Biol. Ecol. 19:233-241.

Korringa, P. 1951. The shell of 0strea edulis as a habitat. Archs. neer1. Z0o1. 10:32-152.

Kudenov, J.D. 1974. The reproductive biology of Eurythoe complanata (Pallas, 1766), (Polychaeta: Amphinomidae). Ph.D. Dissertation. University of Arizona. $154 \mathrm{pp}$.

Kudenov, J.D. 1977. The functional morphology of feeding in three species of maldanid polychaetes. Zool. J. Linn. Soc. Lond. 60: 95-109. 
Kudenov, J.D. 1978. The feeding ecology of Axiothella rubrocincta (Johnson) (Polychaeta: Maldanidae). J. Exp. Mar. Biol. Ecol. $31: 209-221$.

Lance, G.N. and W.T. Williams. 1967. A general theory of classificatory sorting strategies. I. Hierarchial systems. Comput. J. 9:373-380.

Levin, L.A. 1980. Dispersion, feeding behavior and competition in two spionid polychaetes. J. Mar. Res. 39(1):98-117.

Linke, 0. 1939. Die Biota des Jadebusenwattes. Helgolander Wiss. Meeresunters. 1:201-348.

Malone, T.C., W.E. Esaias and P. Falkowski. 1979. Plankton dynamics and nutrient cycling. Part 1. Water column processes. Chapter 9 In: Oxygen Depletion and Associated Benthic Mortalities in New York Bight, 1976/ NOAA Professional Paper 11.345 pp.

Mangum, C.P. 1964. Studies on speciaiton in maldanid polychaetes of the North American Atlantic Coast. II. Distribution and competitive interaction of five sympatric species. Limnol. Oceanogr. 9(1):12-26.

Mangum, C.P. and C.D. Cox. 1971. Analysis of the feeding response in the onuphid polychaete, Diopatra cuprea. Biol. Bull. Mar. Biol. Lab., Woods Hole. 140:215:229.

Maurer, D. and W. Leathem. 1981. Polychaete feeding guilds from Georges Bank, USA. Mar. Biol. 62:161-171.

McCaffrey, R.J., A.C. Myers, E. Davey, G. Morrison, M. Bender, N. Leudtke, D. Cullen, P. Froelich and G. Klinkhammer. 1980. The relation between pore water chemistry and benthic fluxes of nutrients and manganese in Narragansett Bay, Rhode Island. Limnol. Oceanogr. 25:31-44.

McKinney, T.F., W.L. Stubblefield and D.J.P. Swift. 1974. Large-scale current lineations on the central New Jersey shelf: investigations by side-scan sonar. Mar. Geol. 17:79-102.

Mettam, C. 1980. Short note on the feeding habits of Aphrodita acleata and commensal polynoids. J. Mar. Biol. Ass. U.K. 60: 833-834.

Milliman, J.D. 1973. Marine geology. Pages 10-1 - 10-91. In: S.B. Saila (coord.). Coastal and Off shore Environmental Inventory, Cape Hatteras to Nantucket Shoa 1s. Mar. Publ. Ser. 3, Univ. of Rhode Island, Kingston, RI. 
Mortensen, T. 1922. Biologiske studier over Sandstrandsfaunaen, searlig ved de danske Kyster. Videns. Meddr. dansk. naturh. Foren. 74:23-56.

Myers, A.C. 1972. Tube-worm-sediment relationships of Diopatra cuprea (Polychaeta: Onuphidae). Mar. Biol. 17:350-355.

Newe11, R.C. 1970. Biology of Intertidal Animals. Logos Press Ltd., London. $555 \mathrm{pp}$.

Okada, Y.K. 1928. Feeding organs and feeding habits of Autolytus edwarsi St. Joseph. Q. J. Microsc. Sci. 72:219-245.

Oug, E. 1980. On feeding and behavior of Ophiodromus flexuosus (Delle Chaije) and Nereimyra punctata (0.F. Muller) (Polychaeta, Hesionidae). Ophelia 19(2):175-191.

Pearson, T.H. 1971. Studies on the ecology of the macrobenthic fauna of Lochs Linnhe and Eil, West Coast of Scotland II. Analysis of the macrobenthic fauna by comparison of feeding groups. Vie Mileu Supp 1. 22:53-91.

Pettibone, M.H. 1957. Endoparasitic polychaetous annelids of the family Arabellidae with a description of a new species. Biol. Bull. Mar. Biol. Lab., Woods Hole. 113:170-187.

Pettibone, M.H. 1963. Marine polychaete worms of the New England region. Aphroditidae - Trochochaetidae. Bul1. U.S. Natl. Mus. No. $227.356 \mathrm{pp}$.

Pratt, S.D. 1973. Benthic Fauna. Pages 5-1 to 5-70. In: Coastal Offshore Environmental Inventory, Cape Hatteras to Nantucket Shoa Is. Mar. Publ. Ser. Univ. Rhode Island.

Rao, D.S. and D.V.R. Sarma. 1978. Food and feeding habits of Nephtys oligobranchia Southern (Annelida: Polychaeta). Indian J. Mar. Sci. 7:193-195.

Rasmussen, E. 1973. Systematics and ecology of the Isefjord marine fauna (Denmark) with a survey of the eelgrass (Zostera) vegetation and its communities. Ophelia 11:1-507.

Retiere, C. 1967. Place du Spionidae Nerine cirratulua (Della Chiaje) dans les sables littoraux de la plage de Lancieux (Cotes-du-Nord). Interactions alimentaires des differentes especes du annelidien. Bul1. Soc. Scient. Bretagne 42:39-47.

Rhoads, D.C. 1967. Biogenic reworking of intertidal and subtidal sediments in Barnstable Harbor and Buzzards Bay, Massachusetts. J. Geol. 74(4):61-76. 
Rhoads, D.C. 1974. Organism-sediment relations on the muddy sea floor. Oceanogr. Mar. Biol. Ann. Rev. 12:263-300.

Rhoads, D.C. and D.K. Young. 1970. The influence of deposit-feeding organisms on sediment stability and community trophic structure. J. Mar. Res. 28(2):150-178.

Rhoads, D.C., P.L. McCall and J.Y. Yingst. 1978. Disturbance and production on the estuarine seafloor. Am. Sci. 66(4):577-586.

Risk, M.J. and V.J. Tunnicliffe. 1978. Intertidal spiral burrows: Paraonis fulgens and Spiophanes wigleyi in the Minas Basin, Bay of Fundy. J. Sed. Petro1. 48(4):1287-1292.

Roder, H. 1971. Gangsysteme von Paraonis fulgens Levinsen 1883 (Polychaeta) in okologischer, ethologischer und aktuopalaontologischer Sicht. Senckenberg. Marit. 3:3-51.

Roe, P. 1975. Aspects of life history and of territorial behavior in young individuals of Platynereis bicaniculata and Nereis vexillosa (Annelida, Polychaeta). Pacif. Sci. 29:341-348.

Ronan, T.E., Jr. 1977. Formation and paleontologic recognition of structures caused by marine annelids. Paleobiology $3(4): 389-403$.

Sanders, H.L. 1956. Oceanography of Long Island Sound, 1952-1954. Buil. Bingham Oceanogr. Coll. 15:345-414.

Sanders, H.L. 1960. Benthic studies in Buzzards Bay III. The structure of the soft-bottom community. Limnol. Oceanogr. 3:245258.

Sanders, H.L., E.M. Goudsmit, E.L. Mills and G.E. Hampson. 1962. A study of the intertidal fauna of Barnstable Harbor, Massachusetts. Limnol. Oceanogr. 7(1):63-79.

Schafer, W. 1962. Aktus-Palaontologie nach Studien in der Nordsee. W. Kramer. Frankfurt am Main. $666 \mathrm{pp}$.

Schmitz, W.J. 1974. Observations of low-frequency current fluctuations on the continental slope and rise near site $D$. J. Mar. Res. $32(2): 233-251$.

Shaffer, P.L. 1979. The feeding biology of Podarke pugettensis (Polychaeta: Hesionidae). Biol. Bul1. 156:34 $\overline{3-355 .}$

Simon, J.L. 1965. Feeding in the annelid Eteone heteropoda. Q. J. Fla. Acad. Sci. 28(4):370-372. 
Soka 1, R.R. and F.J. Rohlf. 1981. Biometry, 2nd edition. W.H. Freeman and Co., San Francisco. 859 pp.

Southward, E.C. 1957. The distribution of Polychaeta in offshore deposits in the Irish Sea. J. Mar. Biol. Ass. U.K. 36:49-75.

Stanley, D.J. and D.J.P. Swift. 1976. Marine Sediment Transport and Environmenta 1 Management. J. Wiley, New York, 602 pp.

Steimle, F.W. and D.J. Radosh. 1979. Effects on the benthic invertebrate community. Chapter 12 In: 0xygen Depletion and Associated Benthic Mortalities in New York Bight, 1976. NOAA Professional Paper 11. $345 \mathrm{pp}$.

Stolte, H.A. 1932. Untersuchungen uber Bau and Funktion der Sinnesorgane der Polychaetengattung Glycera. Z. Wiss. Z001. 140: 421-538.

Stubblefield, W.L., J.W. Lavelle, D.J.P. Swift and T.F. McKinney. 1975. Sediment response to the present hydrautic regime on the central New Jersey shelf. J. Sed. Petrol. 45:337-358.

Stubblefield, W.L. and D.J.P. Swift. 1976. Ridge development as revealed by subbottom profiles on the central New Jersey shelf. Mar. Geol. 20:315-334.

Swanson, R.L. and C.J. Sindermann. 1979. Oxygen Depletion and Associated Benthic Mortalities in New York Bight, 1976. NOAA Professional Paper II. $345 \mathrm{pp}$.

Swift, D.J.P. 1976. Continental shelf sedimentation. Pages 311-350. In: D.J. Stanley and D.J.P. Swift (eds.). Marine Sediment Transport and Environmental Management. J. Wiley, New York.

Swift, D.J.P., D.B. Duane and T.F. McKinney. 1973. Ridge and swale topography of the Middle Atlantic Bight, North America: secular response to the Holocent hydraulic regime. Mar. Geol. 15:227-247.

Swift, D.J.P., J.W. Kofoed, F.P. Saulsbury and P. Sears. 1972. Holocene evolution of the shelf surface, central and southern A tlantic shelf of North America. Pages 499-573. In: D.J.P. Swift, D.B. Duane and O.H. Pilkey (eds.). She Th Sediment Transport: Processes and Patterns. Dowden, Hutchinson and Ross, Stroudsburg, PA.

Swift, D.J.P., T. Nelsen, J. McHone, B. Holliday, H, Palmer and G. Schideler. 1977. Holocene evolution of the inner shelf of southern Virginia. J. Sed. Petrol. 47:1454-1474. 
Taghon, G.L., A.R.M. Nowe11 and P.A. Jumars. 1980. Induction of suspension feeding in spionid polychaetes by high particulate fluxes. Science 210:562-564.

Tenore, K.R., R.B. Hanson, B.E. Dornseif and D.N. Wiederhold. 1979. The effect of organic nitrogen suppliment on the utilization of different sources of detritus. Limnol. Oceanogr. 24:350-355.

Thayer, C.W. 1979. Biological bulldozers and the evolution of marine benthic communities. Science 203:458-461.

Tsuchiya, M. and Y. Kurihara. 1979. The feeding habits and food sources of the deposit-feeding polychaete, Neanthes japonica (Izuka). J. Exp. Mar. Biol. Ecol. 36:79-89.

Tsuchiya, M. and Y. Kurihara. 1980. Effect of the feeding behavior of macrobenthos on changes in environmental conditions of intertidal flats. J. Exp. Mar. Biol. Ecol. 44:85-94.

Uchupi, E. 1970. Atlantic continental shelf and slope of the U.S. shallow structure. U.S. Geol. Surv. Prof. Paper 529I.

Walsh, J.J., T.E. Whitledge, F.W. Barnevik, C.D. Wirick, S.0. Howe, W.E. Esaias and J.T. Scott. 1978. Wind events and food cha in dynamics within the New York Bight. Limnol. Oceanog. 23:659-683.

Welch, C.S. and E.P. Ruzecki. 1979. Physical oceanography and climatology. In: Middle Atlantic Outer Continental Shelf Environmental Studies, Volume IIA. Chemical and Biological Benchmark Studies. Prepared by the Virginia Institute of Marine Science, Gloucester Point, VA, under Contract AA550-CT6-62 with the Bureau of Land Management, U.S. Department of Interior.

Westheide, W. 1967. Monographie der Gattungen Hesionides Friedrich und Microphtha lmus Mecznikow (Polychaeta, Hesionidae). Z. Morph. 0kol. Tiere. 61:1-159.

Whitlatch, R.B. 1981. Animal-sediment relationships in intertidal marine benthic habitats: some determinants of deposit-feeding species diversity. J. Exp. Mar. Biol. Ecol. 53:31-45.

Wigley, R.L. and R.B. Theroux. 1976. Macrobenthic invertebrate fauna of the Middle Atlantic Bight region. Part II. Faunal composition and quantitative distribution. National Marine Fisheries Center, Woods Hole, Mass. $395 \mathrm{pp}$.

Wigley, R.L. and R.B. Theroux. 1981. Atlantic continental shelf and slope of the United States--Macrobenthic invertebrate fauna of the Middle Atlantic Bight Region--Faunal composition and quantitative distribution. Geol. Survey Prof. Paper 529N. 198 pp. 
Wigley, R.L., R.B. Theroux and H. Murray. 1976. Macroinvertebrate fauna of the Middle Atlantic Bight region: Part I. U.S. Department of Commerce, NOAA, NMFS, Woods Hole. (unpublished report).

Wolff, W.J. 1973. The estuary as a habitat - An analysis of data of the soft-bottom macrofauna of the estuarine area of the Rivers Rhine, Meuse, and Scheldt. Zool. Verh., Leiden. 126:1-242.

Woodin, S.A. 1974. Polychaete abundance patterns in a marine softsediment environment: The importance of biological interactions. Ecol. Monogr. 44(2):171-187.

Woodin, S.A. 1976. Adult-larval interactions in dense infaunal assemblages: patterns of abundance. J. Mar. Res. 34(1):25-41.

Woodin, S.A. 1977. Algal "gardening" behavior by nereid polychaetes: effects on soft-bottom community structure. Mar. Biol. 44:39-42.

Woodin, S.A. 1978. Refuges, disturbance, and community structure: a marine soft bottom example. Ecology 59(2):274-284.

Yingst, J.Y. and R.C. Aller. 1982. The effect of the polychaete Heteromastus filiformis on bacteria in marine sediments. AGUASLO meeting. San Antonio, Texas. February 16-19, 1982.

Yingst, J.Y. and D.C. Rhoads. 1980. The role of bioturbation in the enhancement of bacterial growth rates in marine sediments. Pages 407-421. In: Marine Benthic Dynamics. K.R. Tenore and B.C. Coul1 (eds.). $451 \mathrm{pp}$.

Yonge, C.M. 1928. Feeding mechanisms in the invertebrates. Biol. Rev. 3:21-76.

Yonge, C.M. 1954. Food of invertebrates. Tab. Biol. 21:19-45.

Zibrowius, H., E.C. Southward and J.H. Day. 1975. New observations on a little-known species of Lumbrineris (Polychaeta) living on various cnidarians, with notes on its recent and fossil schleractinian hosts. J. Mar. Biol. Ass. U.K. 55:83-108. 
VITA

\section{Gary Russe11 Gaston}

Born in Mobile, Alabama, 7 November 1950. Earned Bachelor of Science degree, Biology, University of A labama, December 1972. Earned Master of Science degree, Marine Science, University of Alabama, May 1976. Worked as a marine scientist at the Virginia Institute of Marine Science, November 1976 to November 1980. Entered College of William and Mary as a graduate student, January 1978. Presently a faculty member at McNeese State University, Lake Charles, Louisiana.

Gary R. Gaston

Research and Development

McNeese State University

Lake Charles, Louisiana 